U.S. Department of the Interior

U.S. Geological Survey

\title{
Analysis of Geophysical Logs, at North Penn Area 6 Superfund Site, Lansdale, Montgomery County, Pennsylvania
}

by Randall W. Conger

Open-File Report 99-271

prepared in cooperation with the

U.S. ENVIRONMENTAL PROTECTION AGENCY 


\section{U.S. DEPARTMENT OF THE INTERIOR \\ BRUCE BABBITT, Secretary}

U.S. GEOLOGICAL SURVEY

Charles G. Groat, Director

For additional information

write to:

District Chief

U.S. Geological Survey

840 Market Street

Lemoyne, Pennsylvania 17043-1584
Copies of this report may be purchased from:

U.S. Geological Survey

Branch of Information Services

Box 25286

Denver, Colorado 80225-0286 


\section{CONTENTS}

Page

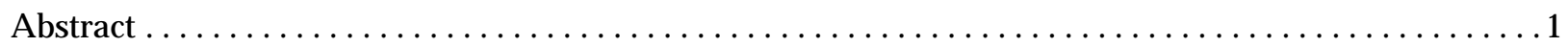

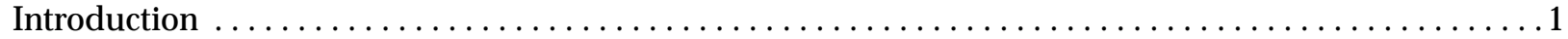

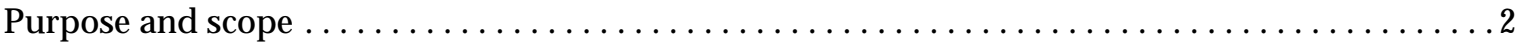

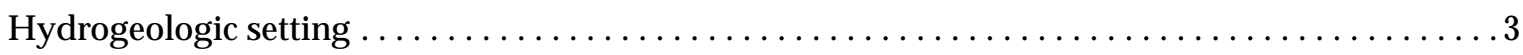

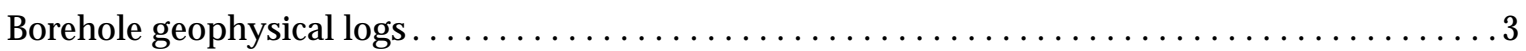

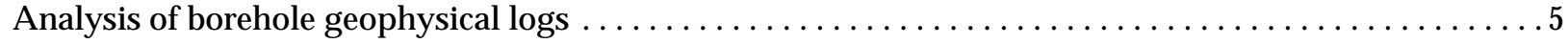

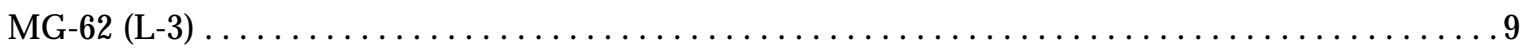

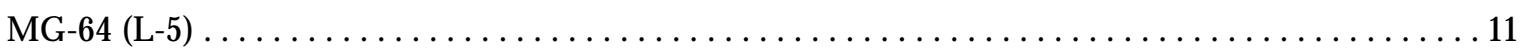

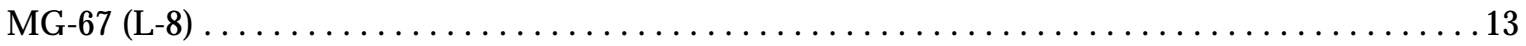

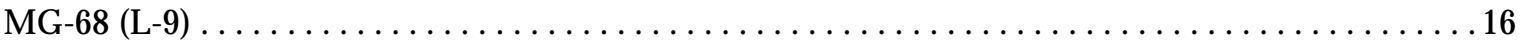

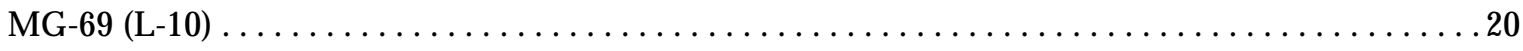

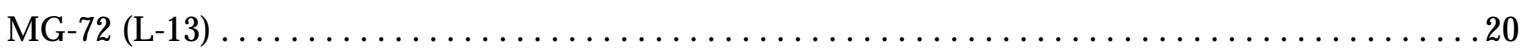

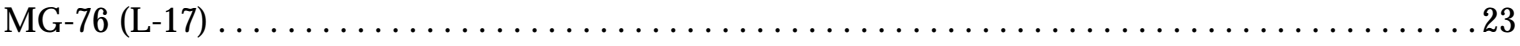

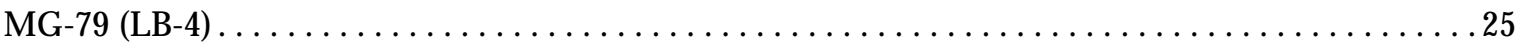

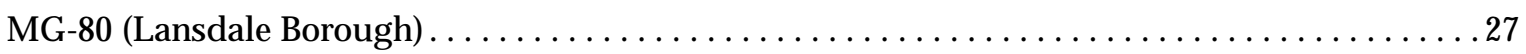

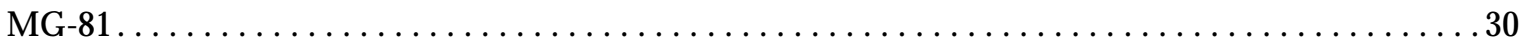

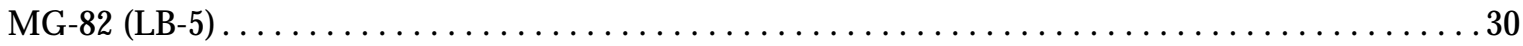

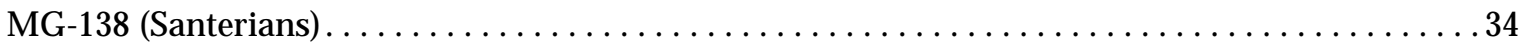

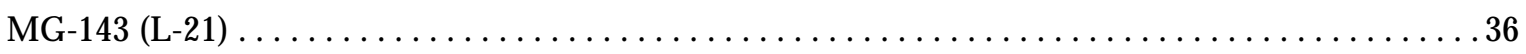

MG-152 (American Olean Tile production well \#1) ............................. 36

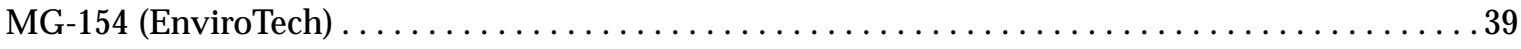

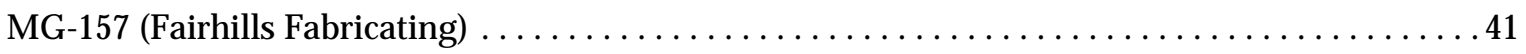

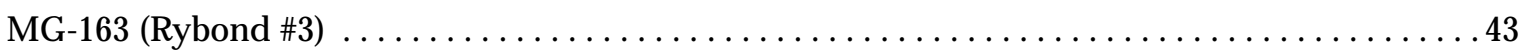

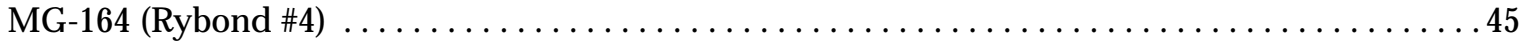

MG-498 (L-23) ..............................................

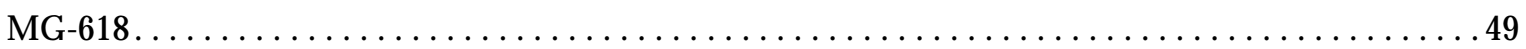

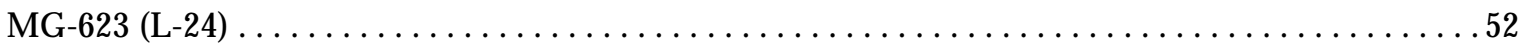

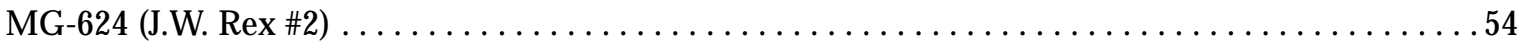

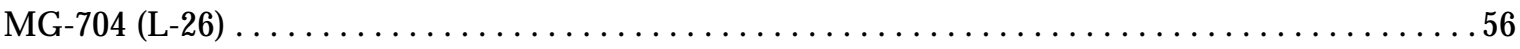

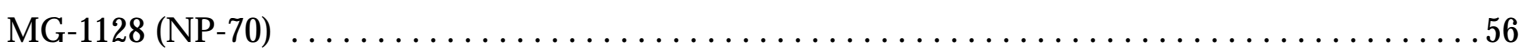

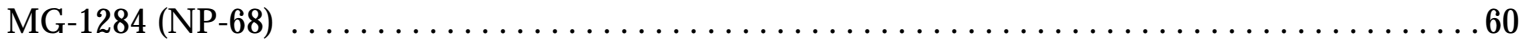

MG-1440 (Crystal Soap) . . . . . . . . . . . . . . . . . . . . . . . . . . . . . 62

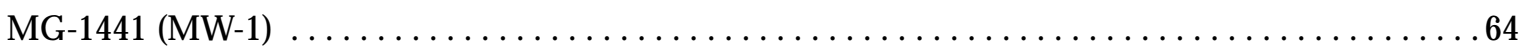

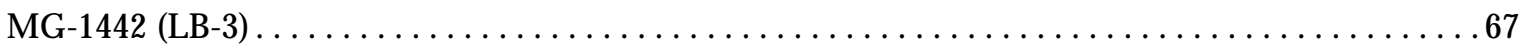

MG-1443 (Philadelphia Toboggan and Coaster Company) .........................66 


\section{CONTENTS-Continued}

Analysis of borehole geophysical logs—Continued

MG-1444 (Roger's Mechanical) . . ........................................ 71

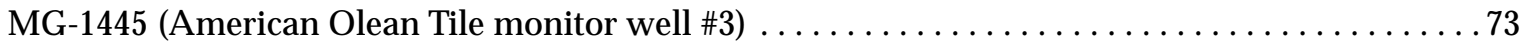

MG-1446 (American Olean Tile monitor well \#1) . . . . . . . . . . . . . . . . . . . . 75

MG-1447 (American Olean Tile monitor well \#2) . . . . . . . . . . . . . . . . . . . . .77

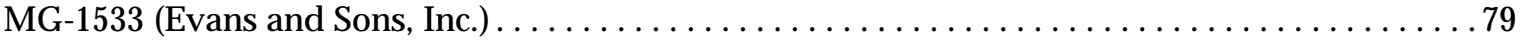

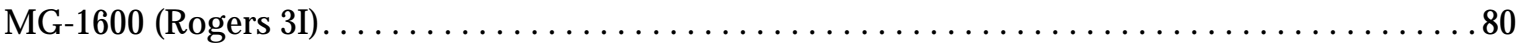

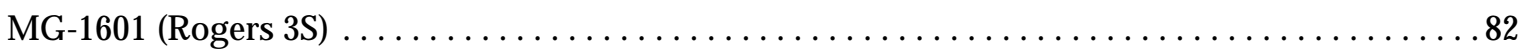

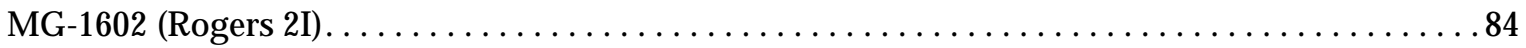

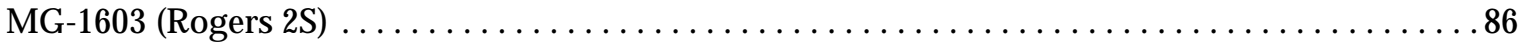

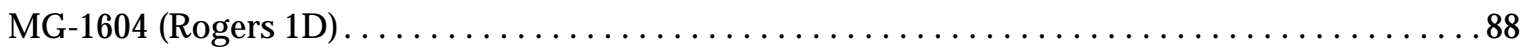

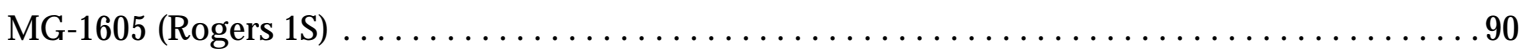

MG-1606 (Philadelphia Toboggan and Coaster Company 1S). ...................... 92

MG-1607 (Philadelphia Toboggan and Coaster Company 1I) ........................ 94

MG-1608 (Philadelphia Toboggan and Coaster Company 1D) . .................... 96

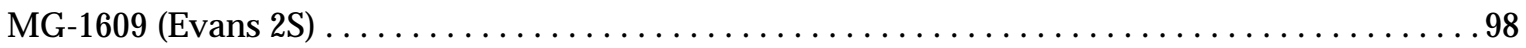

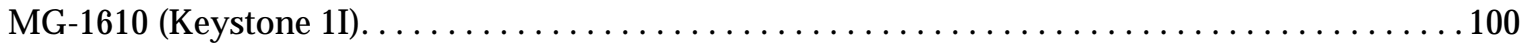

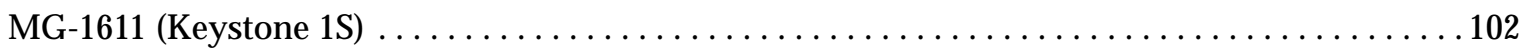

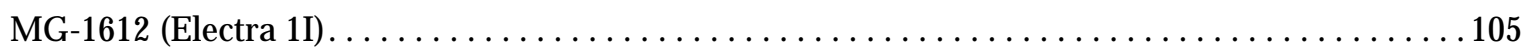

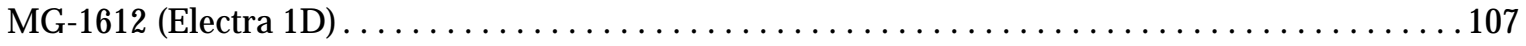

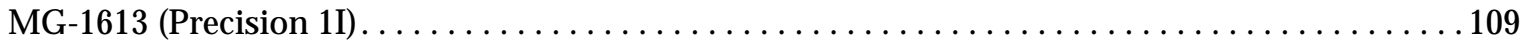

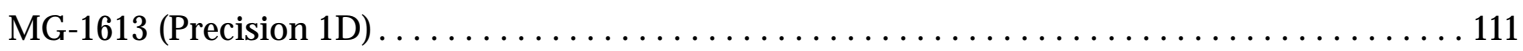

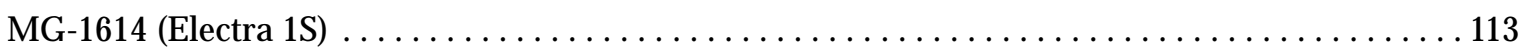

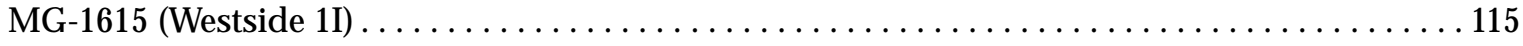

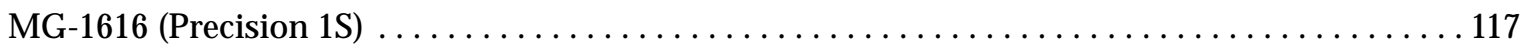

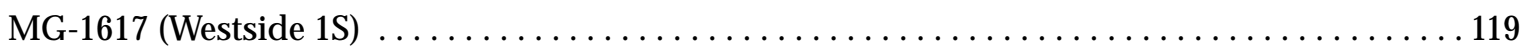

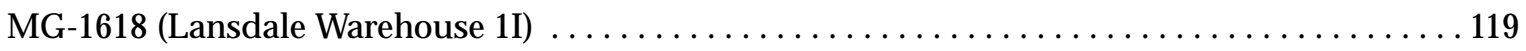

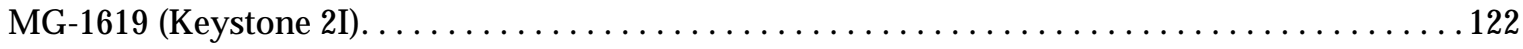

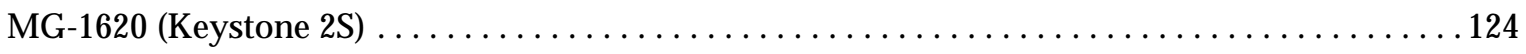

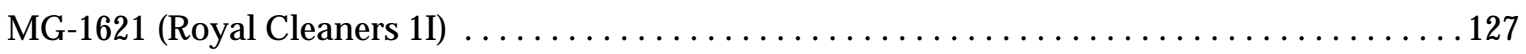

MG-1622 (Lansdale Warehouse 1S) . . . . . . . . . . . . . . . . . . . . . . . . . . 129

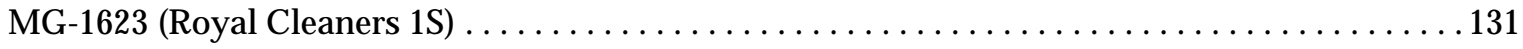

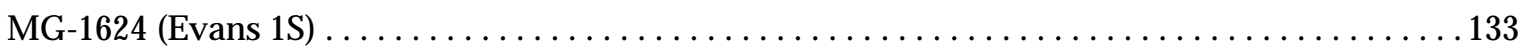

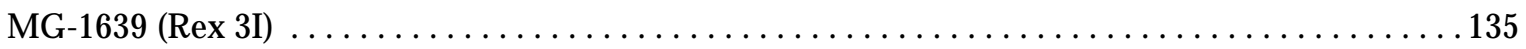

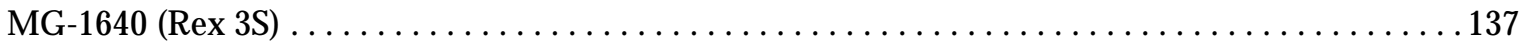

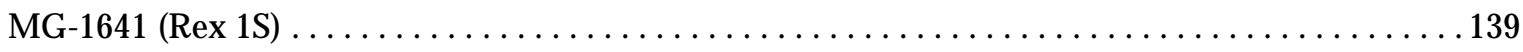




\section{CONTENTS-Continued}

Correlation of natural-gamma logs

Conclusions.

References cited

\section{ILLUSTRATIONS}

Figure 1. Map showing location of boreholes logged at North Penn Area 6 Superfund Site, Lansdale, Montgomery County, Pennsylvania........................ 2

2-4. Borehole geophysical logs and direction of nonpumping flow within boreholes:

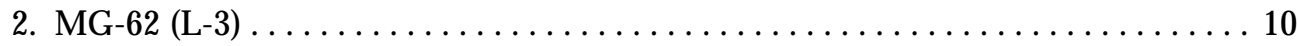

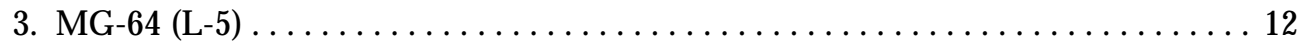

4. MG-67 (L-8) ...................................... 14

5. Deviation log showing magnitude and direction of deviation from vertical

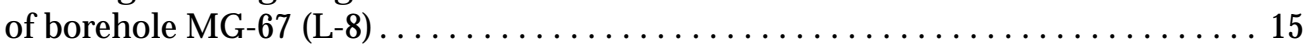

6. Stereonet showing equal-area lower hemisphere, stereographic projection of poles perpendicular to fracture planes in borehole MG-67 (L-8) . . . . . . . . . . . 15

7. Borehole geophysical logs and direction of nonpumping flow within borehole MG-68 (L-9) ........................................ 17

8. Deviation log showing magnitude and direction of deviation from vertical

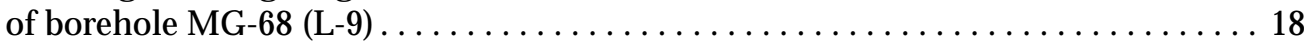

9. Stereonet showing equal-area lower hemisphere, stereographic projection of poles perpendicular to fracture planes in borehole MG-68 (L-9) . . . . . . . . . . . . 18

10-14. Borehole geophysical logs and direction of nonpumping flow within boreholes:

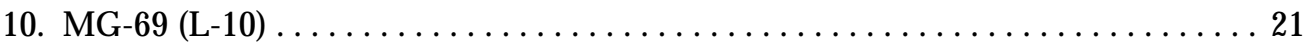

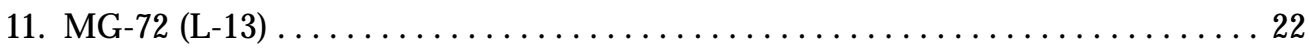

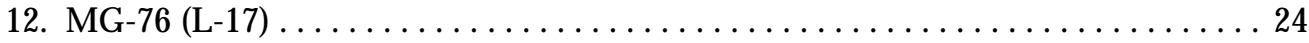

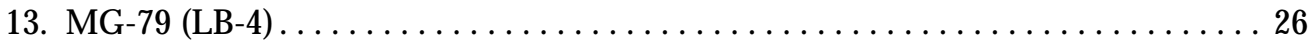

14. MG-80 (Lansdale Borough) . . . . . . . . . . . . . . . . . . 28

15. Deviation log showing magnitude and direction of deviation from vertical of borehole MG-80 (Lansdale Borough). . . . . . . . . . . . . . . . . . . . . . 29

16. Stereonet showing equal-area lower hemisphere, stereographic projection of poles perpendicular to fracture planes in borehole MG-80 (Lansdale Borough). . . . . . . 29

17. Borehole geophysical logs and direction of nonpumping flow within borehole MG-81 .............................................. 31

18. Deviation log showing magnitude and direction of deviation from vertical

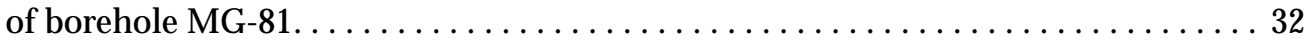

19. Stereonet showing equal-area lower hemisphere, stereographic projection of poles perpendicular to fracture planes in borehole MG- $81 \ldots \ldots \ldots \ldots \ldots \ldots \ldots \ldots 32$ 


\section{ILLUSTRATIONS-Continued}

Figure 20-29. Borehole geophysical logs and direction of nonpumping flow within boreholes:

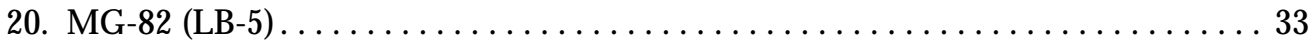

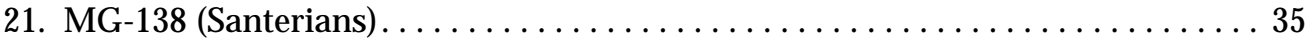

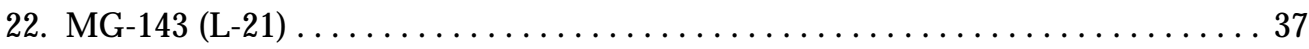

23. MG-152 (American Olean Tile production well \#1). . . . . . . . . . . . 38

24. MG-154 (EnviroTech) . .................................. 40

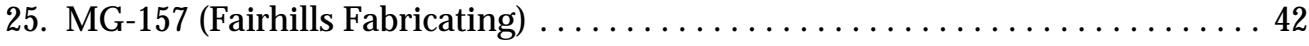

26. MG-163 (Rybond \#3) .................................... 44

27. MG-164 (Rybond \#4) ..................................... 46

28. MG-498 (L-23) ................................... 48

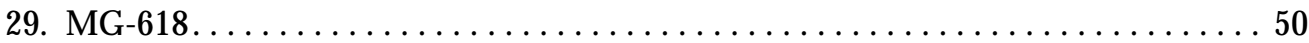

30. Deviation log showing magnitude and direction of deviation from vertical of borehole MG-618. . . . . . . . . . . . . . . . . . . . . . . . . . 51

31. Stereonet showing equal-area lower hemisphere, stereographic projection of poles perpendicular to fracture planes in borehole MG-618 . . . . . . . . . . . . . 51

32-35. Borehole geophysical logs and direction of nonpumping flow within boreholes:

32. MG-623 (L-24) . . . . . . . . . . . . . . . . . . . . . . . . 53

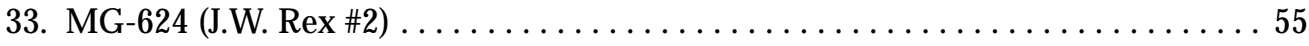

34. MG-704 (L-26) ....................................... 57

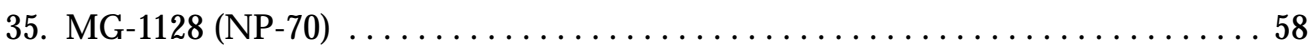

36. Deviation log showing magnitude and direction of deviation from vertical of borehole MG-1128 (NP-70) . . . . . . . . . . . . . . . . . . . . . . . . 59

37. Stereonet showing equal-area lower hemisphere, stereographic projection of poles perpendicular to fracture planes in borehole MG-1128 (NP-70) . . . . . . . . . . 59

38-40. Borehole geophysical logs and direction of nonpumping flow within boreholes:

38. MG-1284 (NP-68) . . . . . . . . . . . . . . . . . . . . . . 61

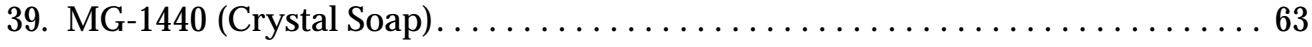

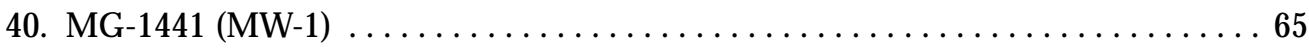

41. Deviation log showing magnitude and direction of deviation from vertical of borehole MG-1441 (MW-1) . . . . . . . . . . . . . . . . . . . . . . . . . 66

42. Stereonet showing equal-area lower hemisphere, stereographic projection of poles perpendicular to fracture planes in borehole MG-1441 (MW-1) . . . . . . . . 66

43. Natural gamma log for borehole MG-1442 (LB-3) $\ldots \ldots \ldots \ldots \ldots \ldots \ldots \ldots \ldots \ldots \ldots \ldots \ldots \ldots \ldots$

44. Borehole geophysical logs and direction of nonpumping flow within borehole MG-1443

(Philadelphia Toboggan and Coaster Company) .......................... 69

45. Deviation log showing magnitude and direction of deviation from vertical of borehole MG-1443 (Philadelphia Toboggan and Coaster Company) . . . . . . . 70 


\section{ILLUSTRATIONS-Continued}

Page

Figure 46. Stereonet showing equal-area lower hemisphere, stereographic projection of poles perpendicular to fracture planes in borehole MG-1443 (Philadelphia Toboggan and Coaster Company) . . . . . . . . . . . . . . . . . . . . . . . . . . 70

47-50. Borehole geophysical logs and direction of nonpumping flow within boreholes:

47. MG-1444 (Roger's Mechanical) . ......................... 72

48. MG-1445 (American Olean Tile monitor well \#3) . . . . . . . . . . . . . . . 74

49. MG-1446 (American Olean Tile monitor well \#1) . . . . . . . . . . . . . . . 76

50. MG-1447 (American Olean Tile monitor well \#2) . . . . . . . . . . . . . . . 78

51. Borehole geophysical logs for borehole MG-1533 (Evans and Sons, Inc.) . . . . . . . . 79

52-63. Borehole geophysical logs and direction of nonpumping flow within boreholes:

52. MG-1600 (Rogers 3I) .................................. 81

53. MG-1601 (Rogers 3S) ................................. 83

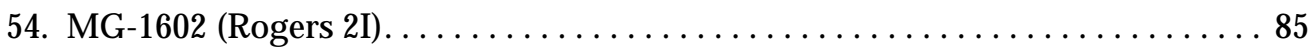

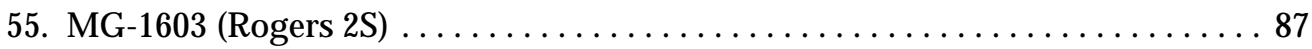

56. MG-1604 (Rogers 1D) ..................................... 89

57. MG-1605 (Rogers 1S) . ............................... 91

58. MG-1606 (Philadelphia Toboggan and Coaster Company 1S) ........... 93

59. MG-1607 (Philadelphia Toboggan and Coaster Company 1I) . ............. 95

60. MG-1608 (Philadelphia Toboggan and Coaster Company 1D) ............. 97

61. MG-1609 (Evans $2 \mathrm{~S})$. . . . . . . . . . . . . . . . . . . . . . . . . 99

62. MG-1610 (Keystone 1I) . . . . . . . . . . . . . . . . . . . . . . . 101

63. MG-1611 (Keystone 1S) . ................................. 103

64. Deviation log showing magnitude and direction of deviation from vertical

of borehole MG-1611 (Keystone 1S) . . . . . . . . . . . . . . . . . . . . . 104

65. Stereonet showing equal-area lower hemisphere, stereographic projection of poles perpendicular to fracture planes in borehole MG-1611 (Keystone 1S) . . . . . . . . 104

66-76. Borehole geophysical logs and direction of nonpumping flow within boreholes:

66. MG-1612 (Electra 1I) . . . . . . . . . . . . . . . . . . . . . . 106

67. MG-1612 (Electra 1D) . . . . . . . . . . . . . . . . . . . . . . 108

68. MG-1613 (Precision 1I) .................................. 110

69. MG-1613 (Precision 1D) .................................... 112

70. MG-1614 (Electra 1S) . ................................. 114

71. MG-1615 (Westside 1I) . . . . . . . . . . . . . . . . . . . . . 116

72. MG-1616 (Precision 1S) . .............................. 118

73. MG-1617 (Westside 1S) . .............................. 120

74. MG-1618 (Lansdale Warehouse 1I) .......................... 121 


\section{ILLUSTRATIONS-Continued}

Figure 66-76. Borehole geophysical logs and direction of nonpumping flow within boreholes:

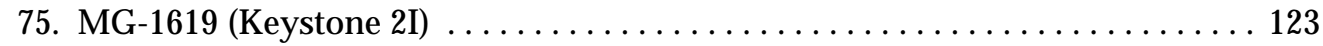

76. MG-1620 (Keystone 2S) . ................................. 125

77. Deviation log showing magnitude and direction of deviation from vertical

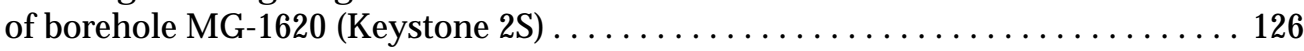

78. Stereonet showing equal-area lower hemisphere, stereographic projection of poles perpendicular to fracture planes in borehole MG-1620 (Keystone 2S) . . . . . . . 126

79-84. Borehole geophysical logs and direction of nonpumping flow within boreholes:

79. MG-1621 (Royal Cleaners 1I) . . . . . . . . . . . . . . . . . . . 128

80. MG-1622 (Lansdale Warehouse 1S) . . . . . . . . . . . . . . . . . . 130

81. MG-1623 (Royal Cleaners 1S) . . . . . . . . . . . . . . . . . . . . 132

82. MG-1624 (Evans 1S) . . . . . . . . . . . . . . . . . . . . . . . . 134

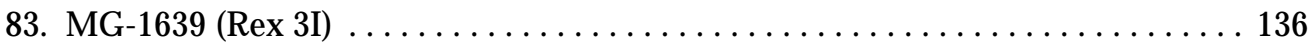

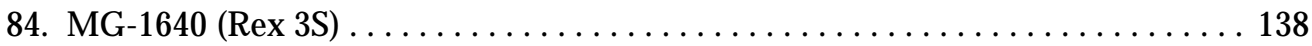

85. Borehole geophysical logs for borehole MG-1641 (Rex 1S) . . . . . . . . . . . . 140 86-91. Correlation of natural gamma logs:

86. MG-1600, MG-1444, MG-1602, MG-1603, MG-1605, and MG-1604,

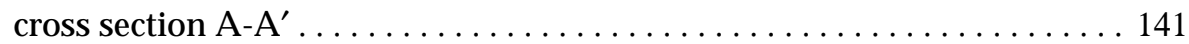

87. MG-81, MG-1612, MG-1614, MG-1608, and MG-618,

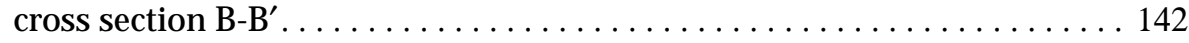

88. MG-164, MG-163, MG-80, MG-1620, MG-1619, MG-67, MG-1615, and

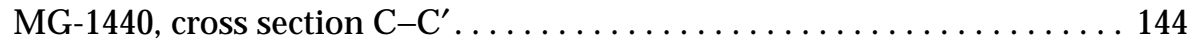

89. MG-498, MG-624, and MG-704, cross section D-D' . . . . . . . . . . . . . . 146

90. MG-62, MG7-64, and MG-924, cross section E-E' . . . . . . . . . . . . . . . . . . 147

91. MG-1616, MG-1613, MG-1624, and MG-1445, cross section F-F' . . . . . . . . 148 


\section{TABLES}

Page

Table 1. Boreholes logged at North Penn Area 6 Superfund Site, August 22, 1995 through August 29, 1997, Lansdale, Montgomery County, Pennsylvania .................. 5

2. Well depth, casing length, and depth to water for boreholes logged by the U.S. Geological Survey at North Penn Area 6 Superfund Site, August 22, 1995, through August 29, 1997, Montgomery County, Pennsylvania . . . . . . . 7

3-57. Summary of heatpulse-flowmeter measurements for boreholes at North Penn Area 6 Superfund Site, Lansdale, Montgomery County, Pennsylvania:

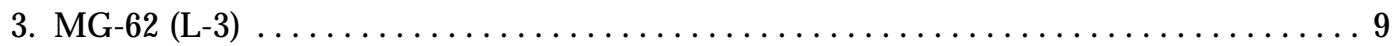

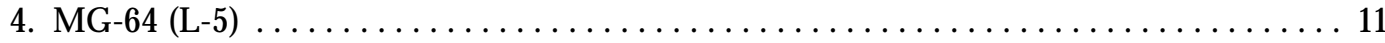

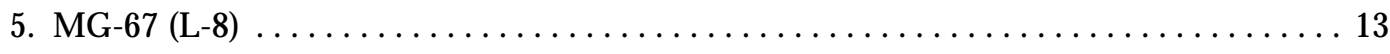

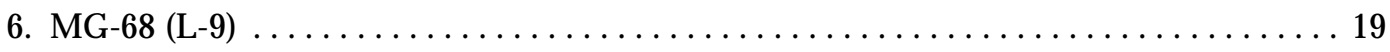

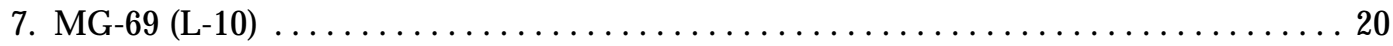

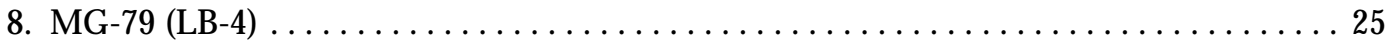

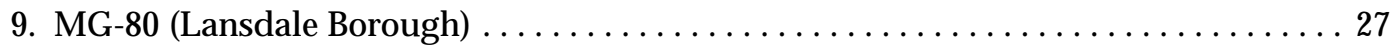

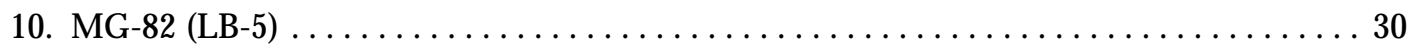

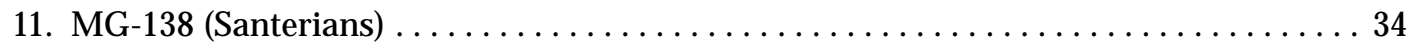

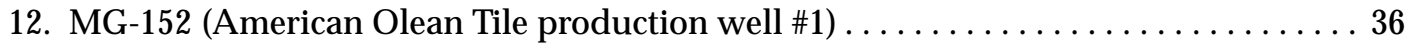

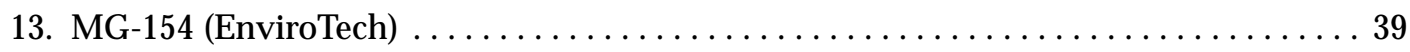

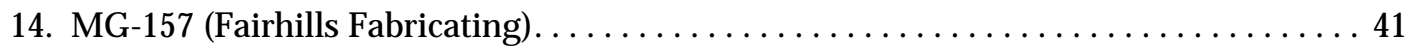

15. MG-163 (Rybond \#3) . . . . . . . . . . . . . . . . . . . . . . 43

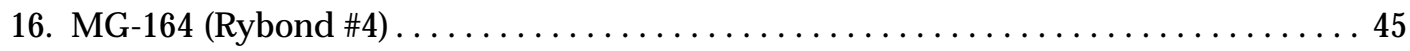

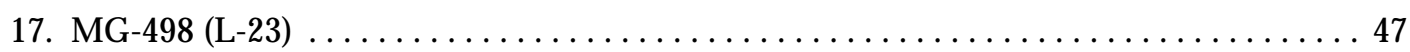

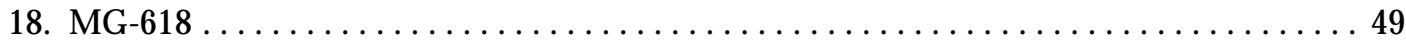

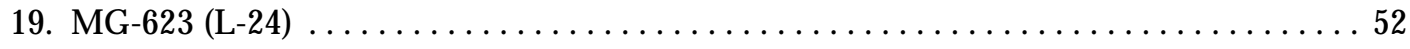

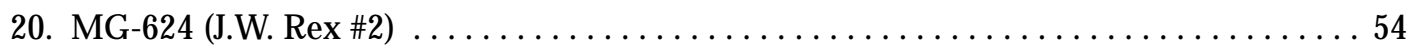

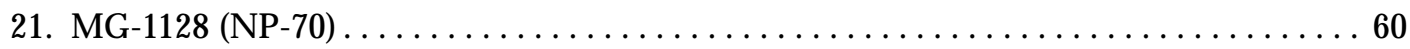

22. MG-1284 (NP-68) . . . . . . . . . . . . . . . . . . . . . . . . 62

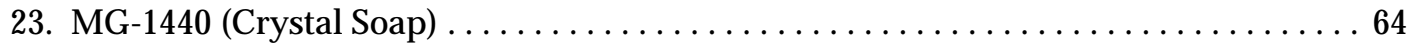

24. MG-1441 (MW-1) . . . . . . . . . . . . . . . . . . . . . . . . . . 64

25. MG-1443 (Philadelphia Toboggan and Coaster Company) $\ldots \ldots \ldots \ldots \ldots \ldots \ldots 6$

26. MG-1444 (Roger's Mechanical) . . . . . . . . . . . . . . . . . . . . . . . 71

27. MG-1445 (American Olean Tile monitor well \#3) . . . . . . . . . . . . . . 73

28. MG-1446 (American Olean Tile monitor well \#1) . . . . . . . . . . . . . . . . . . 75

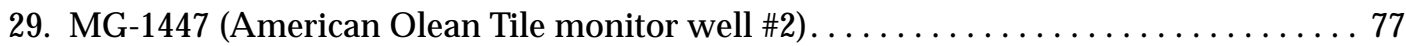

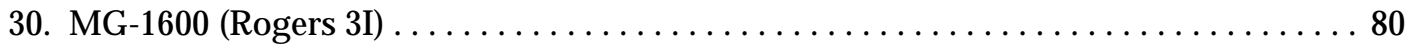

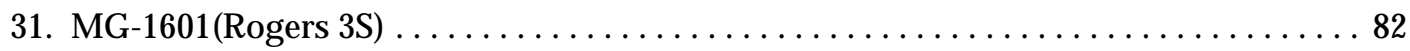

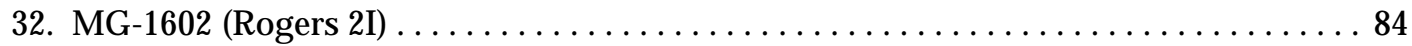




\section{TABLES-Continued}

Tables 3-57. Summary of heatpulse-flowmeter measurements for boreholes at North Penn Area 6 Superfund Site, Lansdale, Montgomery County, Pennsylvania-Continued:

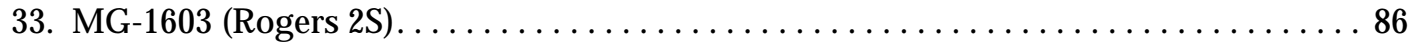

34. MG-1604 (Rogers 1D) . . . . . . . . . . . . . . . . . . . . . . . . 88

35. MG-1605 (Rogers 1S) . . . . . . . . . . . . . . . . . . . . . . . . 90

36. MG-1606 (Philadelphia Toboggan and Coaster Company 1S) . ............. 92

37. MG-1607 (Philadelphia Toboggan and Coaster Company 1I) . . . . . . . . . . . . . 94

38. MG-1608 (Philadelphia Toboggan and Coaster Company 1D) .............. 96

39. MG-1609 (Evans 2S) . . . . . . . . . . . . . . . . . . . . . . . . . . 98

40. MG-1610 (Keystone 1I) . . . . . . . . . . . . . . . . . . . . . . . 100

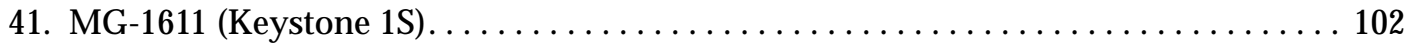

42. MG-1612 (Electra 1I) . . . . . . . . . . . . . . . . . . . . . . . . 105

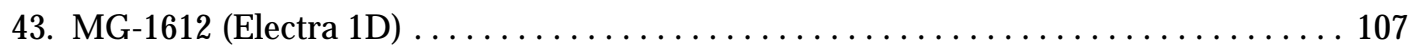

44. MG-1613 (Precision 1I) . . . . . . . . . . . . . . . . . . . . . . . . . 109

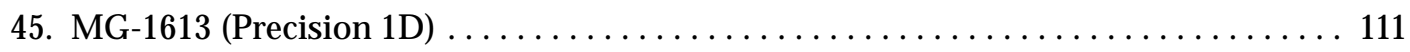

46. MG-1614 (Electra 1S) ...................................... 113

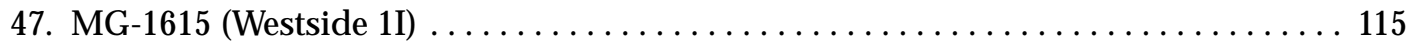

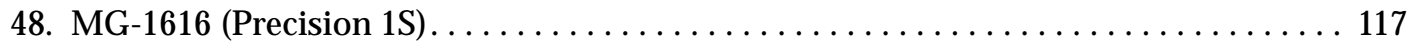

49. MG-1618 (Lansdale Warehouse 1I) . . . . . . . . . . . . . . . . . . . . 119

50. MG-1619 (Keystone 2I) . . . . . . . . . . . . . . . . . . . . . . . 122

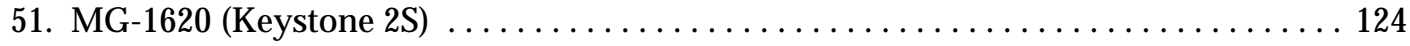

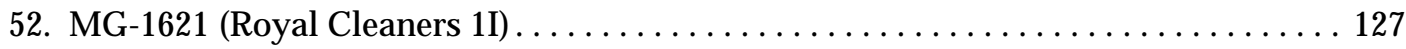

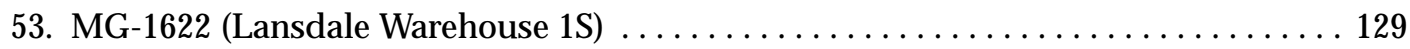

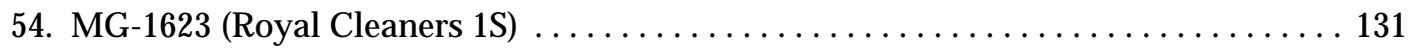

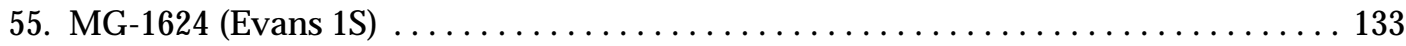

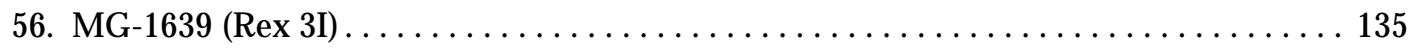

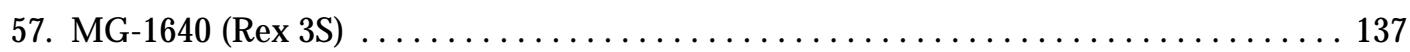




\section{CONVERSION FACTORS, VERTICAL DATUM, AND ABBREVIATIONS}

\begin{tabular}{lll} 
Multiply & By & \multicolumn{1}{c}{ To obtain } \\
inch $(\mathrm{in})$. & 25.40 & millimeter \\
foot $(\mathrm{ft})$ & 0.3048 & meter \\
mile $(\mathrm{mi})$ & 1.609 & kilometer \\
square mile $\left(\mathrm{mi}^{2}\right)$ & 2.590 & square kilometer \\
gallon per minute $(\mathrm{gal} / \mathrm{min})$ & 0.00006309 & cubic meter per second
\end{tabular}

Vertical datum: In this report, "sea level" refers to the National Geodetic Vertical Datum of 1929-a geodetic datum derived from a general adjustment of the first-order level nets of the United States and Canada, formerly called Sea Level Datum of 1929.

Abbreviated water-quality units used in report:

$\mu \mathrm{g} / \mathrm{L}$, micrograms per liter 


\title{
ANALYSIS OF GEOPHYSICAL LOGS, AT NORTH PENN AREA 6 SUPERFUND SITE, LANSDALE, MONTGOMERY COUNTY, PE NNSYLVANIA
}

\author{
by Randall W. Conger
}

\begin{abstract}
The U.S. Geological Survey (USGS), as part of technical assistance to the U.S. Environmental Protection Agency (USEPA), collected borehole geophysical log data in 34 industrial, commercial, and public supply wells and 28 monitor wells at the North Penn Area 6 Superfund Site, in Lansdale, Pa., from August 22, 1995, through August 29, 1997. The wells range in depth from 50 to 1,027 feet below land surface and are drilled in Triassic-age shales and siltstones of the Brunswick Group and Lockatong Formation. The geophysical log data were collected to help describe the hydrogeologic framework in the area and to provide guidance in the reconstruction of the 28 monitor wells drilled during summer 1997. At the time of logging, all wells had open-hole construction.

The geophysical logs, caliper, fluid-resistivity, and fluid-temperature, and borehole video logs were used to determine the vertical distribution of water-bearing fractures. Heatpulse-flowmeter measurements were used to determine vertical borehole flow under pumping and nonpumping conditions. The most productive fractures generally could be determined from heatpulse-flowmeter measurements under pumping conditions. Vertical borehole flow was measured under nonpumping conditions in most wells that had more than one water-bearing fracture. Upward flow was measured in 35 wells and probably is a result of natural head differences between fractures in the local ground-water-flow system. Downward flow was measured in 11 wells and commonly indicated differences in hydraulic heads of the fractures caused by nearby pumping. Both upward and downward flow was measured in three wells. No flow was detected in eight wells.

Natural-gamma-ray logs were used to estimate the attitude of bedding. Thin shale marker beds, shown as spikes of elevated radioactivity in the natural-gamma logs of some wells throughout the area, enable the determination of bedding-plane orientation from three-point correlations. Generally, the marker beds in and near Lansdale strike about N. $48^{\circ}-60^{\circ}$ E. and dip about $11^{\circ} \mathrm{NW}$. Acoustic televiewer logs run in selected boreholes indicate that the attitude of many water-bearing fractures commonly is similar to that of bedding.
\end{abstract}

\section{INTRODUCTION}

Ground water at the North Penn Area 6 (NP6) Superfund Site is contaminated with organic solvents. The site covers about $3 \mathrm{mi}^{2}$ in and near Lansdale, Montgomery County, Pa., and includes at least six properties identified as potential sources of contamination (Black and Veatch, 1994). The location of the 62 production-type and monitor wells logged at the site are shown in figure 1. Some industries in the area have been operating since the 1940's, whereas others began operations as late as the 1980's (Black and Veatch, 1994). Various solvents, degreasers, and other types of organic compounds-such as trichloroethylene (TCE), 1,1,1-trichloroethane (1,1,1-TCA), and tetrachloroethylene (PCE)—and metals were used by these industries (CH2MHill, 1991).

In 1979, TCE was measured in concentrations greater than $4.5 \mu \mathrm{g} / \mathrm{L}$ in eight North Penn Water Authority (NPWA) public supply wells in the Lansdale area (Black and Veatch, 1994). This concentration nearly exceeds the U.S. Environmental Protection Agency's (USEPA) maximum contaminant level in drinking water of $5 \mu \mathrm{g} / \mathrm{L}$ (U.S. Environmental Protection Agency, 1994). In 1986, the USEPA Region III requested water-use information from 17 industries in the area, and numerous residential wells were sampled. The NP6 was placed on the National Priority List (NPL) in March 1989. Results of environmental investigations by property owners, the Pennsylvania Department of Environmental Protection (PADEP), and by USEPA and its contractors confirmed that the ground water beneath the Borough of Lansdale is contaminated with volatile organic compounds (VOC's). Concentrations of TCE as great as 9,240 $\mu \mathrm{g} / \mathrm{L}$ were measured in water samples from municipal public supply wells, and VOC's also were detected in 


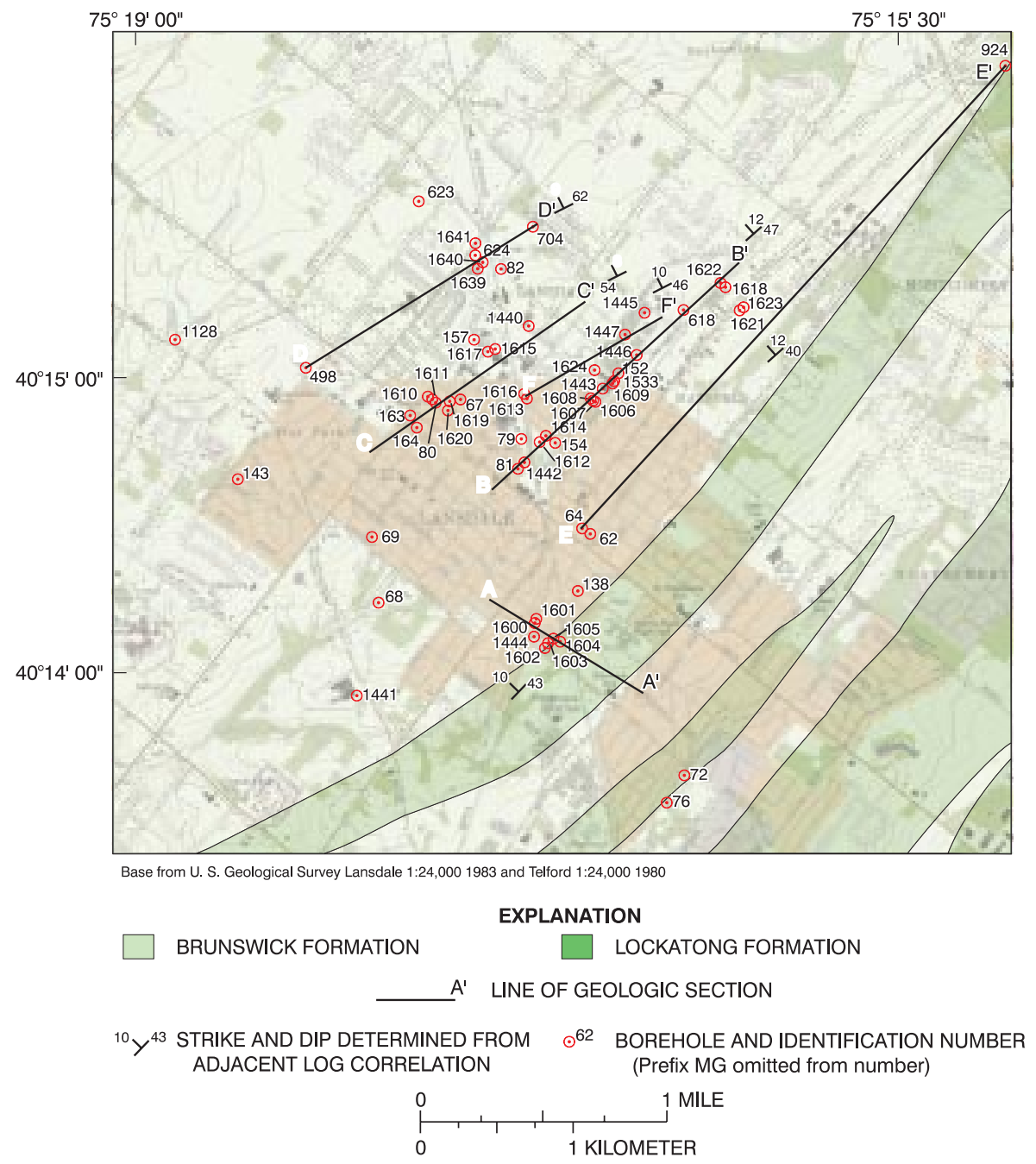

Figure 1. Location of boreholes logged at North Penn Area 6 Superfund Site, Lansdale, Montgomery County, Pennsylvania.

samples from industrial and domestic wells and in samples from a tributary to West Branch Neshaminy Creek (CH2MHill, 1991). A Remedial Investigation/Feasibility Study (RI/FS) was initiated by the USEPA and its contractors in 1991.

The USGS provided technical assistance to the USEPA in the RI/FS. That assistance included the collection and analysis of borehole-geophysical data at existing industrial, commercial, and public-supply wells and at monitor wells installed specifically for the RI/FS during the summer of 1997. The geophysical data were collected to help describe the hydrogeologic framework in the area and to provide guidance in the reconstruction of new monitor wells drilled in 1997.

\section{Purpose and Scope}

This report describes the analysis of borehole geophysical logs and video logs collected by the USGS in 62 boreholes at and near the NP6 Superfund Site from August 1995 to August 1997. Caliper, naturalgamma, single-point-resistance, fluid-resistivity, fluid-temperature, and borehole-flow (heatpulseflowmeter) logs were collected in most boreholes. Borehole video logs were collected in 19 boreholes. The purpose of the analysis of geophysical logs and video logs is to (1) investigate the vertical distribution of water-bearing fractures, (2) help characterize the ground-water flow system, and (3) determine the local geologic structure of the aquifer. 


\section{Hydrogeologic Setting}

The NP6 site is in the Gettysburg-Newark Lowlands Section of the Piedmont Physiographic Province. The site and surrounding area are underlain by sedimentary rocks of the lower Brunswick Group and Lockatong Formation of the Newark Supergroup (Lyttle and Epstein, 1987; Longwill and Wood, 1965; Berg and Dodge, 1981). Contacts between the Brunswick Group and the underlying Lockatong Formation are conformable and gradational, and the two formations interfinger (Longwill and Wood, 1965). The lower beds of the Brunswick Group consist predominantly of homogeneous, soft, red to reddish-brown mudstone and shale and some thin gray, brownish, and green shales (Rima, 1955; Longwill and Wood, 1965). Mudcracks, ripple marks, crossbeds, and burrows are common in all beds; some beds are micaceous (Lyttle and Epstein, 1987). Bedding planes are discontinuous and irregular (Rima, 1955). The lower Brunswick Group rocks contain detrital cycles of medium- to dark-gray and olive- to greenish-gray, thin-bedded and evenly bedded shale and siltstone that grade into the underlying Lockatong Formation (Lyttle and Epstein, 1987). Rocks of the Lockatong Formation contain detrital cycles of gray to black calcareous shale and siltstone, with some pyrite, and chemical cycles of gray to black dolomitic siltstone and marlstone with lenses of pyritic limestone, overlain by massive gray to red siltstone with analcime (Lyttle and Epstein, 1987; Rima and others, 1962). Beds generally strike northeast and dip to the northwest.

The NP6 site is on relatively flat upland terrain that is a surface-water divide between the Wissahickon Creek to the southwest, Towamencin Creek to the west, and tributaries to the West Branch Neshaminy Creek to the north and northeast.

Ground water at the NP6 site originates from infiltration of local precipitation and discharges to streams and to pumped wells, and leaks downward to deeper ground-water flow systems. Precipitation infiltrates the soil and weathered overburden, enters the ground water, and moves through vertical and horizontal fractures in the sandstone, shale, and siltstones. Primary porosity in the Brunswick Group is very low or nonexistent (Longwill and Wood, 1965). Therefore, primary permeability is also small. Ground water in the upper part of the Brunswick Group may be under unconfined (water-table) conditions. Ground water in the intermediate and deep part of the aquifer may be confined or semi-confined, resulting in borehole flow and local artesian conditions. Generally, wells constructed as open-hole boreholes deeper than approximately $50 \mathrm{ft}$ penetrate multiple water-producing or water-receiving zones, and water levels measured in these wells represent composite heads. Where differences in potentiometric head are present, water in the borehole flows from zones of higher head to zones of lower head. Also, pumping from deeper zones may induce downward flow from shallower zones.

The depth to water in wells at the NP6 site range from about 6 to $69 \mathrm{ft}$ below land surface (bls). Groundwater levels fluctuate with local pumping and seasonal variations in recharge. On a regional scale, ground water generally flows in a direction similar to the topographic gradient. In the Lansdale area, however, the configuration of water levels mapped in August 1996 (Senior and others, 1998) indicates the water table does not exactly reflect topography and cones of depression have formed as a result of pumping. The natural direction of flow probably is altered by pumping in many locations. In the rocks of the Brunswick Group, cones of depression caused by pumping tend to extend along strike or fracture orientation (Longwill and Wood, 1965).

\section{Borehole Geophysical Logs}

Geophysical logs provide information on location and orientation of fractures (caliper logs and video logs), water-producing and water-receiving zones, intervals of vertical borehole flow (fluid-resistivity and fluid-temperature logs), quantification of borehole flow (heatpulse-flowmeter data), lithologic correlation (gamma and single-point-resistance logs), and data on well construction (caliper and single-pointresistance logs).

Caliper logs provide a continuous record of average borehole diameter, which is related to bit size, fractures, lithology, and drilling technique. Caliper logs are used to identify fractures and possible waterproducing openings and correct other geophysical logs for changes in borehole diameter. Correlation of caliper logs with fluid-resistivity and fluid-temperature logs is used to identify fractures, water-producing zones, and water-receiving zones. 
The natural-gamma or gamma log measures the natural-gamma radiation (photons) emitted from all rocks. The most common emitters of gamma radiation are uranium-238, thorium-232, their daughter elements, and potassium-40. These radioactive elements are concentrated in clays by adsorption, precipitation, and ion exchange. Fine-grained sediments, such as shale or siltstone, usually emit more gamma radiation than sandstone, limestone or dolomite. The gamma log can be collected in the fluid-filled, dry, cased, or uncased parts of a borehole. However, casing does reduce the gamma response. The gamma $\log$ is used to correlate geologic units between wells (Keys, 1990).

The single-point-resistance log records the electrical resistance of a formation between the probe in a water filled borehole below casing and an electrical ground at land surface. Generally, electrical resistance increases with formation grain size and decreases with borehole diameter, water-bearing fractures, and increasing dissolved-solids concentration of borehole water. The single-point-resistance log is used to correlate geology and lithology between wells and may help identify water-producing zones (Keys, 1990).

Fluid resistivity is the inverse of fluid conductivity. The fluid-resistivity log measures the electrical resistivity of the water column in the borehole. The fluid-resistivity probe measures the resistivity of borehole water between electrodes in the probe. Fluid-resistivity logs reflect changes in the dissolved-solids concentration of the borehole water. Fluid-resistivity logs are used to identify water-producing and waterreceiving zones and to determine intervals of vertical borehole flow. Water-producing and water-receiving zones are usually identified by distinct changes in resistivity. Intervals of vertical borehole flow are usually identified by a low-resistivity gradient between a water-producing and a water-receiving zone.

Fluid-temperature logs provide a continuous record of the temperature of the water in a borehole. Temperature logs are used to identify water-producing and water-receiving zones and to determine zones of vertical flow within the borehole. Intervals of vertical borehole flow are characterized by little or no temperature gradient (Williams and Conger, 1990).

The direction and rate of borehole-fluid movement is determined by the use of a heatpulse-flowmeter. The heatpulse-flowmeter operates by heating a small sheet of water between two sensitive thermistors (heat sensors). A measurement of direction and rate is computed when a peak temperature is recorded by one of the thermistors. The range of flow measurement is about $0.01-1.5 \mathrm{gal} / \mathrm{min}$ in a 2 - to 10 -in.-diameter borehole (Conger, 1996). Some heatpulse-flowmeter measurements may be influenced by (1) poor seal integrity between the borehole and heatpulse flowmeter and (2) contributions of water from storage within the borehole. If the seal between the borehole and flowmeter is not complete, some water can bypass the flowmeter, resulting in measurements of flow that are less than the actual rate. Although the heatpulse flowmeter is a calibrated probe, the data are primarily used as a relative indicator to identify fluidproducing zones.

The borehole acoustic televiewer log is a magnetically oriented, 360 degree photograph-like image of the acoustic reflection of the borehole wall. The acoustic televiewer is an ultrasonic imaging tool operating at a frequency of about 1 megahertz that scans the borehole wall with an acoustic beam generated by a pulsed piezoelectric source rotating at about 3 revolutions per second as the tool is moved up the borehole at about $5 \mathrm{ft} / \mathrm{min}$. Digital images of a 3- to 9-in.-diameter fluid-filled uncased borehole are recorded by a computer collecting the data. The log is represented in two dimensions by splitting the image vertically along the north axis and lain flat. A smooth and hard borehole wall produces a uniform reflection pattern. The intersection of a fracture with the borehole wall scatters the acoustic waves, producing dark, linear features. Because the image is magnetically oriented, the dip and strike of the fracture can be determined.

Borehole deviation logs record the deviation of a borehole from true vertical. Deviation of boreholes from the vertical is common, and deviation logs are used to calculate true vertical depth of features of interest and to correct the strike and dip of fractures or bedding obtained from acoustic televiewer logs.

Video logs were conducted by lowering a waterproof camera down the borehole and recording the image on video tape. The depth indicated on the video log may not correspond exactly to the geophysical logs because of some minor slippage of the television cable. 


\section{ANALYSIS OF BOREHOLE GEOPHYSICAL LOGS}

The locations of boreholes logged are shown on figure 1. A cross-reference between boreholeidentification numbers used by the USGS and the NPWA and a list of logs collected in each borehole are shown in table 1 . The reference measuring point for all geophysical logs and video logs is in feet below land surface. Depth of wells, casing lengths, and water levels at the time of logging are given in table 2. At the time of logging, all wells had open-hole construction. Some of the new monitor wells drilled in summer 1997 were reconstructed after geophysical logging. The new monitor wells include wells MG-1600 to MG-1624, and MG-1639 to MG-1641.

Table 1. Boreholes logged at North Penn Area 6 Superfund Site, August 22, 1995, through August 29, 1997, Lansdale, Montgomery County, Pennsylvania

[A, acoustic televiewer; B, borehole video; C, caliper log; G, natural-gamma; R, single-point-resistance; F, fluid-resistivity log; T, fluid-temperature log; V, borehole-flow measurement; -, not applicable]

\begin{tabular}{|c|c|c|c|}
\hline $\begin{array}{l}\text { U.S. Geological } \\
\text { Survey local well } \\
\text { number }\end{array}$ & Owner well number & $\begin{array}{l}\text { Depth logged } \\
\quad \text { (feet) }\end{array}$ & Geophysical logs run \\
\hline MG-62 & L-3 & 382 & $\mathrm{C}, \mathrm{R}, \mathrm{G}, \mathrm{F}, \mathrm{T}, \mathrm{V}, \mathrm{B}$ \\
\hline MG-64 & L-5 & 1,027 & $\mathrm{C}, \mathrm{R}, \mathrm{G}, \mathrm{F}, \mathrm{T}, \mathrm{V}$ \\
\hline MG-67 & L-8 & 294 & $A, C, R, G, F, T, V, B$ \\
\hline MG-68 & L-9 & 460 & $A, C, R, G, F, T, V, B$ \\
\hline MG-69 & L-10 & 251 & $\mathrm{C}, \mathrm{R}, \mathrm{G}, \mathrm{F}, \mathrm{T}, \mathrm{V}, \mathrm{B}$ \\
\hline MG-72 & L-13 & 298 & $\mathrm{C}, \mathrm{R}, \mathrm{G}, \mathrm{F}, \mathrm{T}, \mathrm{V}, \mathrm{B}$ \\
\hline MG-76 & L-17 & 367 & $\mathrm{C}, \mathrm{R}, \mathrm{G}, \mathrm{F}, \mathrm{T}$ \\
\hline MG-79 & LB- 4 & 284 & $\mathrm{C}, \mathrm{R}, \mathrm{G}, \mathrm{F}, \mathrm{T}, \mathrm{V}$ \\
\hline MG-80 & Lansdale Borough & 270 & $\mathrm{~A}, \mathrm{C}, \mathrm{R}, \mathrm{G}, \mathrm{F}, \mathrm{T}, \mathrm{V}, \mathrm{B}$ \\
\hline MG-81 & - & 350 & $A, C, R, G, F, T, V, B$ \\
\hline MG-82 & LB-5 & 92 & $\mathrm{C}, \mathrm{R}, \mathrm{G}, \mathrm{F}, \mathrm{T}, \mathrm{V}, \mathrm{B}$ \\
\hline MG-138 & Santerians & 424 & $\mathrm{C}, \mathrm{R}, \mathrm{G}, \mathrm{F}, \mathrm{T}, \mathrm{V}$ \\
\hline MG-143 & L-21 & 392 & $\mathrm{C}, \mathrm{R}, \mathrm{G}, \mathrm{F}, \mathrm{T}, \mathrm{V}, \mathrm{B}$ \\
\hline MG-152 & American Olean Tile production well \# 1 & 196 & $\mathrm{C}, \mathrm{R}, \mathrm{G}, \mathrm{F}, \mathrm{T}, \mathrm{V}$ \\
\hline MG-154 & EnviroTech & 182 & $\mathrm{C}, \mathrm{R}, \mathrm{G}, \mathrm{F}, \mathrm{T}, \mathrm{V}$ \\
\hline MG-157 & Fairhills Fabricating & 268 & $\mathrm{C}, \mathrm{R}, \mathrm{G}, \mathrm{F}, \mathrm{T}, \mathrm{V}$ \\
\hline MG-163 & Rybond \# 3 & 318 & $\mathrm{C}, \mathrm{R}, \mathrm{G}, \mathrm{F}, \mathrm{T}, \mathrm{V}, \mathrm{B}$ \\
\hline MG-164 & Rybond \# 4 & 385 & $\mathrm{C}, \mathrm{R}, \mathrm{G}, \mathrm{F}, \mathrm{T}, \mathrm{V}, \mathrm{B}$ \\
\hline MG-498 & L-23 & 587 & $\mathrm{C}, \mathrm{R}, \mathrm{G}, \mathrm{F}, \mathrm{T}, \mathrm{V}, \mathrm{B}$ \\
\hline MG-618 & - & 338 & $A, C, R, G, F, T, V, B$ \\
\hline MG-623 & L-24 & 505 & $\mathrm{C}, \mathrm{R}, \mathrm{G}, \mathrm{F}, \mathrm{T}, \mathrm{V}, \mathrm{B}$ \\
\hline MG-624 & J.W. Rex \# 2 & 633 & $\mathrm{C}, \mathrm{R}, \mathrm{G}, \mathrm{F}, \mathrm{T}, \mathrm{V}, \mathrm{B}$ \\
\hline MG-704 & L-26 & 380 & $\mathrm{C}, \mathrm{R}, \mathrm{G}, \mathrm{F}, \mathrm{T}, \mathrm{V}, \mathrm{B}$ \\
\hline MG-924 & NP-21 & 253 & $\mathrm{C}, \mathrm{R}, \mathrm{G}, \mathrm{F}, \mathrm{T}, \mathrm{V}, \mathrm{B}$ \\
\hline MG-1128 & NP-70 & 486 & $\mathrm{~A}, \mathrm{C}, \mathrm{R}, \mathrm{G}, \mathrm{F}, \mathrm{T}, \mathrm{V}$ \\
\hline MG-1284 & NP-68 & 442 & $\mathrm{C}, \mathrm{R}, \mathrm{G}, \mathrm{F}, \mathrm{T}, \mathrm{V}$ \\
\hline MG-1440 & Crystal Soap & 208 & $\mathrm{C}, \mathrm{R}, \mathrm{G}, \mathrm{F}, \mathrm{T}, \mathrm{V}, \mathrm{B}$ \\
\hline MG-1441 & MW-1 & 178 & $A, C, R, G, F, T, V, B$ \\
\hline MG-1442 & LB-3 & 83 & $\mathrm{G}$ \\
\hline MG-1443 & Philadelphia Toboggan and Coaster Company & 339 & $A, C, R, G, F, T, V, B$ \\
\hline MG-1444 & Roger's Mechanical & 294 & $\mathrm{C}, \mathrm{R}, \mathrm{G}, \mathrm{F}, \mathrm{T}, \mathrm{V}, \mathrm{B}$ \\
\hline MG-1445 & American Olean Tile monitor well \# 3 & 204 & $\mathrm{C}, \mathrm{R}, \mathrm{G}, \mathrm{F}, \mathrm{T}, \mathrm{V}$ \\
\hline MG-1446 & American Olean Tile monitor well \# 1 & 144 & $C, R, G, F, T, V$ \\
\hline MG-1447 & American Olean Tile monitor well \# 2 & 145 & $C, R, G, F, T, V$ \\
\hline MG-1533 & Evans and Sons Inc. & 63 & $\mathrm{C}, \mathrm{R}, \mathrm{G}, \mathrm{F}, \mathrm{T}$ \\
\hline MG-1600 & Rogers 3I & 150 & $C, G, R, F, T, V$ \\
\hline
\end{tabular}


Table 1. Boreholes logged at North Penn Area 6 Superfund Site, August 22, 1995, through August 29, 1997, Lansdale, Montgomery County, Pennsylvania-Continued

\begin{tabular}{|c|c|c|c|}
\hline $\begin{array}{l}\text { U.S. Geological } \\
\text { Survey local well } \\
\text { number }\end{array}$ & Owner well number & $\begin{array}{l}\text { Depth logged } \\
\quad \text { (feet) }\end{array}$ & Geophysical logs run \\
\hline MG-1601 & Rogers 3S & 100 & $\mathrm{C}, \mathrm{G}, \mathrm{R}, \mathrm{F}, \mathrm{T}, \mathrm{V}$ \\
\hline MG-1602 & Rogers 2I & 131 & $\mathrm{C}, \mathrm{G}, \mathrm{R}, \mathrm{F}, \mathrm{T}, \mathrm{V}, \mathrm{B}$ \\
\hline MG-1603 & Rogers $2 \mathrm{~S}$ & 98 & $\mathrm{C}, \mathrm{G}, \mathrm{R}, \mathrm{F}, \mathrm{T}, \mathrm{V}$ \\
\hline MG-1604 & Rogers 1D & 221 & $\mathrm{C}, \mathrm{G}, \mathrm{R}, \mathrm{F}, \mathrm{T}, \mathrm{V}, \mathrm{B}$ \\
\hline MG-1605 & Rogers 1S & 95 & $\mathrm{C}, \mathrm{G}, \mathrm{R}, \mathrm{F}, \mathrm{T}, \mathrm{V}$ \\
\hline MG-1606 & Philadelphia Toboggan and Coaster Company 1S & 101 & $\mathrm{C}, \mathrm{G}, \mathrm{R}, \mathrm{F}, \mathrm{T}, \mathrm{V}$ \\
\hline MG-1607 & Philadelphia Toboggan and Coaster Company 1I & 161 & $\mathrm{C}, \mathrm{G}, \mathrm{R}, \mathrm{F}, \mathrm{T}, \mathrm{V}, \mathrm{B}$ \\
\hline MG-1608 & Philadelphia Toboggan and Coaster Company 1D & 307 & $\mathrm{C}, \mathrm{G}, \mathrm{R}, \mathrm{F}, \mathrm{T}, \mathrm{V}, \mathrm{B}$ \\
\hline MG-1609 & Evans $2 S$ & 101 & $\mathrm{C}, \mathrm{G}, \mathrm{R}, \mathrm{F}, \mathrm{T}, \mathrm{V}$ \\
\hline MG-1610 & Keystone 1I & 122 & $\mathrm{C}, \mathrm{G}, \mathrm{R}, \mathrm{F}, \mathrm{T}, \mathrm{V}$ \\
\hline MG-1611 & Keystone 1S & 88 & $\mathrm{~A}, \mathrm{C}, \mathrm{G}, \mathrm{R}, \mathrm{F}, \mathrm{T}, \mathrm{V}$ \\
\hline MG-1612 & Electra 1D & 385 & $\mathrm{C}, \mathrm{G}, \mathrm{R}, \mathrm{F}, \mathrm{T}, \mathrm{V}$ \\
\hline MG-1613 & Precision 1D & 320 & $\mathrm{C}, \mathrm{G}, \mathrm{R}, \mathrm{F}, \mathrm{T}, \mathrm{V}$ \\
\hline MG-1614 & Electra 1S & 121 & $\mathrm{C}, \mathrm{G}, \mathrm{R}, \mathrm{F}, \mathrm{T}, \mathrm{V}$ \\
\hline MG-1615 & Westside 1I & 148 & $\mathrm{C}, \mathrm{G}, \mathrm{R}, \mathrm{F}, \mathrm{T}, \mathrm{V}$ \\
\hline MG-1616 & Precision $1 S$ & 101 & $\mathrm{C}, \mathrm{G}, \mathrm{R}, \mathrm{F}, \mathrm{T}, \mathrm{V}$ \\
\hline MG-1617 & Westside $1 \mathrm{~S}$ & 49 & $\mathrm{C}, \mathrm{G}, \mathrm{R}, \mathrm{F}, \mathrm{T}, \mathrm{V}$ \\
\hline MG-1618 & Lansdale Warehouse 1I & 181 & $\mathrm{C}, \mathrm{G}, \mathrm{R}, \mathrm{F}, \mathrm{T}, \mathrm{V}$ \\
\hline MG-1619 & Keystone 2I & 150 & $\mathrm{C}, \mathrm{G}, \mathrm{R}, \mathrm{F}, \mathrm{T}, \mathrm{V}$ \\
\hline MG-1620 & Keystone 2S & 101 & $\mathrm{~A}, \mathrm{C}, \mathrm{G}, \mathrm{R}, \mathrm{F}, \mathrm{T}, \mathrm{V}$ \\
\hline MG-1621 & Royal Cleaners (1I) & 161 & $\mathrm{C}, \mathrm{G}, \mathrm{R}, \mathrm{F}, \mathrm{T}, \mathrm{V}$ \\
\hline MG-1622 & Lansdale Warehouse 1S & 101 & $\mathrm{C}, \mathrm{R}, \mathrm{F}, \mathrm{T}, \mathrm{V}$ \\
\hline MG-1623 & Royal Cleaners (1S) & 101 & $\mathrm{C}, \mathrm{G}, \mathrm{R}, \mathrm{F}, \mathrm{T}, \mathrm{V}$ \\
\hline MG-1624 & Evans (1S) & 101 & $\mathrm{C}, \mathrm{G}, \mathrm{R}, \mathrm{F}, \mathrm{T}$ \\
\hline MG-1639 & $\operatorname{Rex} 3 \mathrm{I}$ & 149 & $\mathrm{C}, \mathrm{G}, \mathrm{R}, \mathrm{F}, \mathrm{T}, \mathrm{V}$ \\
\hline MG-1640 & $\operatorname{Rex} 3 S$ & 66 & $\mathrm{C}, \mathrm{G}, \mathrm{R}, \mathrm{F}, \mathrm{T}, \mathrm{V}$ \\
\hline MG-1641 & $\operatorname{Rex} 1 \mathrm{~S}$ & 50 & $\mathrm{C}, \mathrm{G}, \mathrm{R}, \mathrm{F}, \mathrm{T}$ \\
\hline
\end{tabular}


Table 2. Well depth, casing length, and depth to water for boreholes logged by the U.S. Geological Survey at North Penn Area 6 Superfund Site, August 22, 1995, through August 29, 1997, Montgomery County, Pennsylvania

[-, not applicable]

\begin{tabular}{|c|c|c|c|c|c|}
\hline $\begin{array}{l}\text { U.S. Geological } \\
\text { Survey local well } \\
\text { number }\end{array}$ & Owner well number & $\begin{array}{l}\text { Depth of well } \\
\text { logged below } \\
\text { measuring point } \\
\text { (feet) }\end{array}$ & $\begin{array}{l}\text { Length of casing } \\
\text { below } \\
\text { measuring point } \\
\text { (feet) }\end{array}$ & $\begin{array}{l}\text { Depth to water } \\
\text { below } \\
\text { measuring point } \\
\text { (feet) }\end{array}$ & $\begin{array}{c}\text { Date } \\
\text { water level } \\
\text { measured }\end{array}$ \\
\hline MG-62 & L-3 & 382 & 30 & 62.50 & $9 / 05 / 95$ \\
\hline MG-64 & $\mathrm{L}-5$ & 1,027 & 6 & 65.57 & $10 / 02 / 95$ \\
\hline MG-67 & L-8 & 294 & 19 & 19.91 & $9 / 29 / 95$ \\
\hline MG-68 & L-9 & 460 & 9 & 41.30 & $7 / 23 / 96$ \\
\hline MG-69 & L-10 & 251 & 39 & 44.66 & $8 / 15 / 96$ \\
\hline MG-72 & L-13 & 298 & 41.5 & 65.63 & $8 / 25 / 95$ \\
\hline MG-76 & L-17 & 367 & 40 & - & - \\
\hline MG-79 & LB-4 & 280 & 7 & 54.73 & $9 / 18 / 95$ \\
\hline MG-80 & Lansdale Borough & 270 & 138 & 13.29 & $5 / 23 / 96$ \\
\hline MG-81 & - & 350 & 33 & 51.70 & $8 / 30 / 95$ \\
\hline MG-82 & LB-5 & 92 & 18 & 13.96 & $9 / 25 / 95$ \\
\hline MG-138 & Santerians & 424 & 22 & 39.59 & $4 / 24 / 96$ \\
\hline MG-143 & L-21 & 392 & 30 & 10.08 & $8 / 22 / 95$ \\
\hline MG-152 & $\begin{array}{l}\text { American Olean Tile } \\
\text { production well \# } 1\end{array}$ & 196 & 22 & 49.41 & $6 / 13 / 96$ \\
\hline MG-154 & EnviroTech & 183 & 35 & 51.16 & $6 / 27 / 97$ \\
\hline MG-157 & Fairhills Fabricating & 268 & 45 & 6.57 & $4 / 29 / 96$ \\
\hline MG-163 & Rybond \# 3 & 318 & 22 & 25.43 & $4 / 30 / 96$ \\
\hline MG-164 & Rybond \# 4 & 385 & 23 & 27.53 & $5 / 08 / 96$ \\
\hline MG-498 & L-23 & 587 & 97 & 46.16 & $8 / 07 / 96$ \\
\hline MG-618 & - & 338 & 29 & 69.48 & $9 / 06 / 95$ \\
\hline MG-623 & L-24 & 505 & 95 & 26.99 & $9 / 27 / 95$ \\
\hline MG-624 & J.W. Rex \# 2 & 633 & 52 & 21.47 & $9 / 19 / 95$ \\
\hline MG-704 & L-26 & 380 & 82 & 21.29 & $8 / 23 / 95$ \\
\hline MG-1128 & NP-70 & 486 & 9 & 18.34 & $5 / 21 / 96$ \\
\hline MG-1284 & NP-68 & 442 & 82 & 9.42 & $8 / 08 / 96$ \\
\hline MG-1440 & Crystal Soap & 208 & 6 & 32.45 & $9 / 08 / 95$ \\
\hline MG-1441 & MW-1 & 178 & 19 & 57.87 & $8 / 30 / 95$ \\
\hline MG-1442 & LB-3 & 84 & unknown & 57.48 & $9 / 18 / 95$ \\
\hline MG-1443 & $\begin{array}{c}\text { Philadelphia Toboggan and Coaster } \\
\text { Company }\end{array}$ & 339 & 10 & 42.09 & $5 / 22 / 96$ \\
\hline MG-1444 & Roger's Mechanical & 294 & 17 & 49.75 & $5 / 30 / 96$ \\
\hline MG-1445 & $\begin{array}{l}\text { American Olean Tile } \\
\text { monitor well \# } 3\end{array}$ & 204 & 21 & 40.09 & $6 / 17 / 96$ \\
\hline MG-1446 & $\begin{array}{l}\text { American Olean Tile } \\
\text { monitor well \# } 1\end{array}$ & 144 & 19 & 53.93 & $6 / 14 / 96$ \\
\hline MG-1447 & $\begin{array}{l}\text { American Olean Tile } \\
\text { monitor well \# } 2\end{array}$ & 145 & 19 & 44.91 & $6 / 18 / 96$ \\
\hline MG-1533 & Evans and Sons, Inc. & 63 & 14 & 47.16 & $6 / 26 / 97$ \\
\hline MG-1600 & Rogers 3I & 150 & 17 & 48.83 & $4 / 23 / 97$ \\
\hline MG-1601 & Rogers 3S & 100 & 13 & 55.35 & $5 / 12 / 97$ \\
\hline MG-1602 & Rogers 2I & 131 & 14 & 55.10 & $4 / 23 / 97$ \\
\hline MG-1603 & Rogers $2 S$ & 98 & 14 & 64.67 & $5 / 12 / 97$ \\
\hline MG-1604 & Rogers 1D & 221 & 14 & 55.48 & $4 / 24 / 97$ \\
\hline MG-1605 & Rogers $1 S$ & 95 & 15 & 60.75 & $5 / 12 / 97$ \\
\hline MG-1606 & $\begin{array}{c}\text { Philadelphia Toboggan and Coaster } \\
\text { Company 1S }\end{array}$ & 101 & 15.5 & 43.12 & $5 / 21 / 97$ \\
\hline
\end{tabular}


Table 2. Well depth, casing length, and depth to water for boreholes logged by the U.S. Geological Survey at North Penn Area 6 Superfund Site, August 22, 1995, through August 29, 1997, Montgomery County, PennsylvaniaContinued

\begin{tabular}{|c|c|c|c|c|c|}
\hline $\begin{array}{l}\text { U.S. Geological } \\
\text { Survey local well } \\
\text { number }\end{array}$ & Owner well number & $\begin{array}{l}\text { Depth of well } \\
\text { logged below } \\
\text { measuring point } \\
\text { (feet) }\end{array}$ & $\begin{array}{l}\text { Length of casing } \\
\text { below } \\
\text { measuring point } \\
\text { (feet) }\end{array}$ & $\begin{array}{l}\text { Depth to water } \\
\text { below } \\
\text { measuring point } \\
\text { (feet) }\end{array}$ & $\begin{array}{c}\text { Date } \\
\text { water level } \\
\text { measured }\end{array}$ \\
\hline MG-1607 & $\begin{array}{l}\text { Philadelphia Toboggan and Coaster } \\
\text { Company 1I }\end{array}$ & 161 & 17.5 & 42.16 & $5 / 13 / 97$ \\
\hline MG-1608 & $\begin{array}{c}\text { Philadelphia Toboggan and Coaster } \\
\text { Company 1D }\end{array}$ & 307 & 221 & 39.67 & $5 / 13 / 97$ \\
\hline MG-1609 & Evans $2 \mathrm{~S}$ & 101 & 19 & 46.45 & $5 / 16 / 97$ \\
\hline MG-1610 & Keystone 1I & 122 & 20 & 13.64 & $5 / 21 / 97$ \\
\hline MG-1611 & Keystone $1 S$ & 88 & 15 & 13.54 & $5 / 21 / 97$ \\
\hline MG-1612 & Electra 1I & 180 & 20 & 50.33 & $5 / 28 / 97$ \\
\hline MG-1612 ${ }^{1}$ & Electra 1D & 384 & 20 & 49.80 & $5 / 29 / 97$ \\
\hline MG-1613 & Precision 1I & 179 & 19 & 25.58 & $6 / 13 / 97$ \\
\hline MG-1613 ${ }^{1}$ & Precision 1D & 320 & 181 & 37.08 & $6 / 24 / 97$ \\
\hline MG-1614 & Electra $1 S$ & 121 & 18 & 50.52 & $6 / 18 / 97$ \\
\hline MG-1615 & Westside 1I & 148 & 18.5 & 15.69 & $6 / 24 / 97$ \\
\hline MG-1616 & Precision 1S & 101 & 20 & 26.55 & $6 / 26 / 97$ \\
\hline MG-1617 & Westside 1S & 49 & 19 & 13.51 & $6 / 26 / 97$ \\
\hline MG-1618 & Lansdale Warehouse 1I & 181 & 20 & 51.96 & $7 / 10 / 97$ \\
\hline MG-1619 & Keystone 2I & 150 & 20 & 11.92 & $6 / 30 / 97$ \\
\hline MG-1620 & Keystone $2 \mathrm{~S}$ & 101 & 20 & 12.15 & $7 / 10 / 97$ \\
\hline MG-1621 & Royal Cleaners (1I) & 161 & 18 & 50.48 & $7 / 17 / 97$ \\
\hline MG-1622 & Lansdale Warehouse 1S & 101 & 20 & 50.37 & $7 / 17 / 97$ \\
\hline MG-1623 & Royal Cleaners (1S) & 101 & 20 & 48.95 & $8 / 01 / 97$ \\
\hline MG-1624 & Evans (1S) & 101 & 18.5 & 38.66 & $8 / 29 / 97$ \\
\hline MG-1639 & Rex 3I & 149 & 19 & 24.68 & $8 / 25 / 97$ \\
\hline MG-1640 & $\operatorname{Rex} 3 S$ & 66 & 23 & 23.33 & $8 / 25 / 97$ \\
\hline MG-1641 & $\operatorname{Rex} 1 S$ & 50 & 18 & 22.48 & $8 / 25 / 97$ \\
\hline
\end{tabular}

${ }^{1}$ Well was drilled deeper because no deep water-producing zones were found. 


\section{MG-62 (L-3)}

The caliper log shows the total depth of the borehole is $382 \mathrm{ft}$ and it is cased with 6-in.-diameter casing to $30 \mathrm{ft}$ bls (fig. 2). The caliper log shows the open borehole is $8 \mathrm{in}$. in diameter and has numerous major and minor fractures throughout the borehole. The static water level was $62.5 \mathrm{ft}$ bls at the time of logging. The natural-gamma log shows shale units with elevated gamma readings at 131-134 ft bls and 254-257 ft bls that might be used for stratigraphic correlation of geologic units with other wells. The fluid-temperature and fluid-resistivity logs show a small change in slope at approximately $316 \mathrm{ft}$ bls that correlates to a vertical fracture on the video log, suggesting a possible water-producing zone. Under nonpumping conditions, the heatpulse flowmeter measured minor upward flow at a rate of $0.02 \mathrm{gal} / \mathrm{min}$ at 304 and $345 \mathrm{ft}$ bls. All other zones measured by the heatpulse flowmeter had flows of $0.01 \mathrm{gal} / \mathrm{min}$ (table 3). A submersible pump was placed at $95 \mathrm{ft} \mathrm{bls,} \mathrm{and} \mathrm{the} \mathrm{well} \mathrm{was} \mathrm{pumped} \mathrm{at} \mathrm{approximately} 1 \mathrm{gal} / \mathrm{min}$. Heatpulse-flowmeter measurements were again made. Borehole flow rate did not increase during pumping. The water level in the well declined $3.61 \mathrm{ft}$ after 1 hour and $22 \mathrm{~min}$ of pumping and never completely stabilized. The suite of borehole geophysical logs and water level and heatpulse-flowmeter measurements suggest the greatest quantity of water enters the borehole through the fractures above $120 \mathrm{ft}$ bls.

Table 3. Summary of heatpulse-flowmeter measurements for borehole MG-62 (L-3) at North Penn Area 6 Superfund Site, Lansdale, Montgomery County, Pennsylvania

[gal/min, gallon per minute]

\begin{tabular}{ccccc}
\hline $\begin{array}{c}\text { Depth } \\
\text { (feet below } \\
\text { land surface) }\end{array}$ & $\begin{array}{c}\text { Flow rate } \\
\text { (gal/min) } \\
\text { nonpumping } \\
\text { conditions }\end{array}$ & $\begin{array}{c}\text { Flow direction } \\
\text { nonpumping } \\
\text { conditions }\end{array}$ & $\begin{array}{c}\text { Flow rate } \\
\text { (gal/min) } \\
\text { pumping } \\
\text { conditions }\end{array}$ & $\begin{array}{c}\text { Flow direction } \\
\text { pumping } \\
\text { conditions }\end{array}$ \\
\hline 120 & no data & no data & 0.01 & up \\
150 & 0.01 & up & .01 & up \\
180 & no data & no data & .01 & up \\
220 & .01 & up & .01 & up \\
260 & .01 & up & .01 & up data \\
268 & .01 & up & .01 & up \\
278 & .01 & up & .01 & up \\
304 & .02 & up & .01 & up \\
325 & .01 & up & no data & no data \\
\hline
\end{tabular}




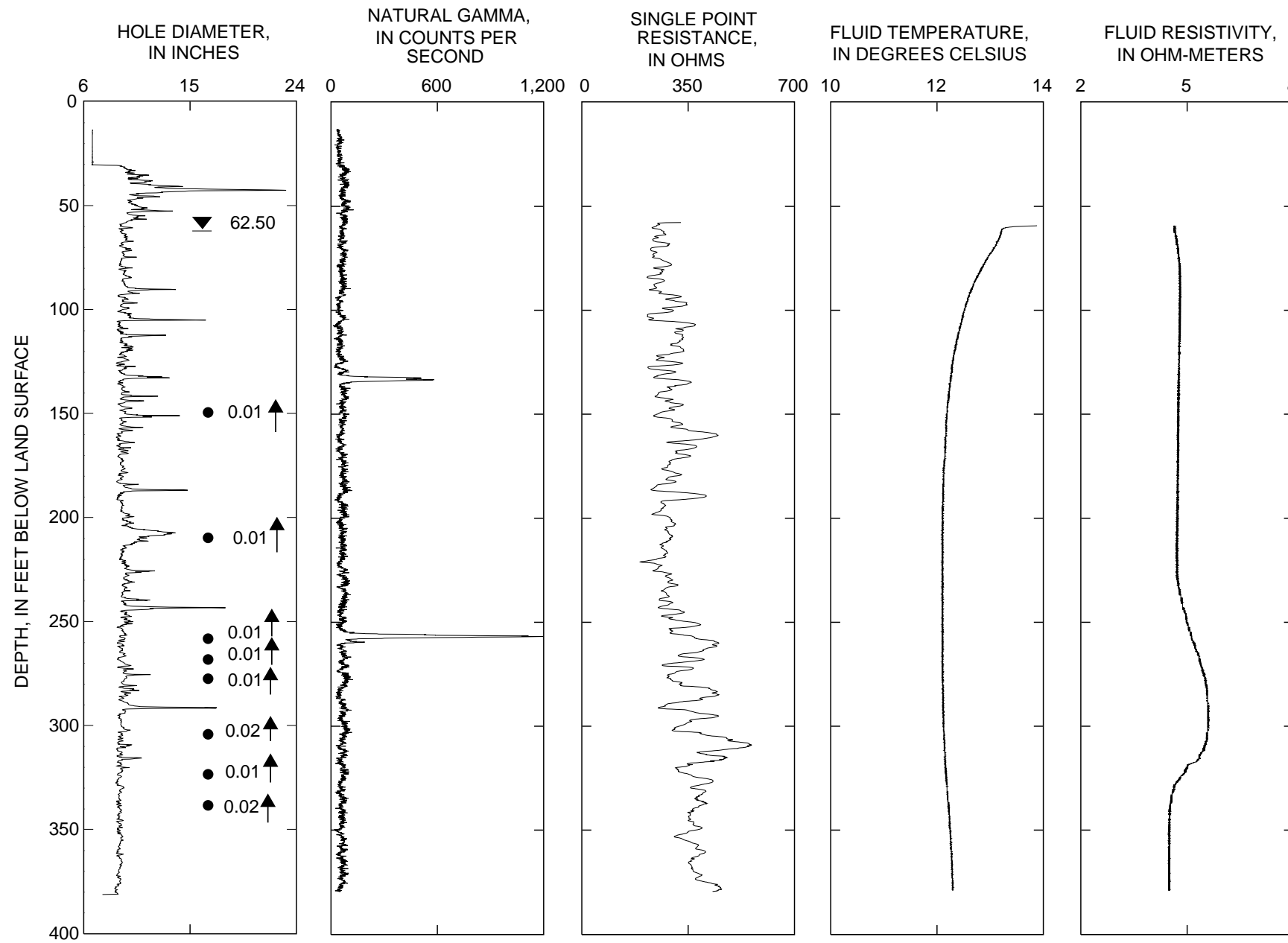

EXPLANATION

₹ STATIC WATER LEVELMeasured in well at the time of geophysical logging

- 0.01 BOREHOLE-FLOW MEASUREMENT UNDER NONPUMPING CONDITIONSCircle at depth of flow measurement. Number is measured flow in gallons per minute.

个 UPWARD BOREHOLE FLOW

Figure 2. Borehole geophysical logs and direction of nonpumping flow within borehole MG-62 (L-3), North Penn Area 6 Superfund Site, Lansdale, Montgomery County, Pennsylvania. 


\section{MG-64 (L-5)}

The caliper $\log$ shows the total depth of the borehole is $1,027 \mathrm{ft}$ and it is cased with 8-in.-diameter casing to $6 \mathrm{ft}$ bls (fig. 3). The caliper log shows major fracture zones at 6-10, 17-28, 88, 111-115, 356-364, 593, $605-611,615,685-693,749$, and 773-778 ft bls plus numerous smaller fractures. The static water level was $65.57 \mathrm{ft}$ bls at the time of logging. The natural-gamma log shows shale units with elevated gamma readings at 144-146, 246-248, 266-270, 303-306, and 614-626 ft bls that might be used for stratigraphic correlation of geologic units with other wells. The fluid-temperature and fluid-resistivity logs show a slight change in slope at $110 \mathrm{ft}$ bls that correlates to a fracture at $111-115 \mathrm{ft}$ bls on the caliper log. The fluid-temperature and fluid-resistivity logs show no evidence of vertical borehole flow above $660 \mathrm{ft}$ bls. Fluid-temperature and fluid-resistivity data were not collected below $660 \mathrm{ft}$ bls because of a hardware malfunction. Under nonpumping conditions, the heatpulse flowmeter measured slight upward flow at 106, 134, 180, 288, 290, 342 , and $376 \mathrm{ft}$ bls (table 4). Heatpulse-flowmeter measurements made at $490 \mathrm{ft}$ bls were not reproducible; therefore, deeper measurements were not made. A submersible pump was placed at $77 \mathrm{ft} b l s$, and the well was pumped at approximately $1 \mathrm{gal} / \mathrm{min}$. Heatpulse-flowmeter measurements were made during pumping at $86,95,106,118,134,154,180,214,288,342,376$, and $490 \mathrm{ft}$ bls. Under pumping conditions, upward borehole flow was measured at $86,95,106,118,134,154,179,214,288,342$, and $376 \mathrm{ft}$ bls. The water level in the well had not completely stabilized when heatpulse-flowmeter measurements were made at 86 , $95,106,118,134$ and $154 \mathrm{ft}$ bls; therefore, the measured flow rates for these intervals may not be compared directly to discharge rates. The suite of borehole geophysical logs and heatpulse-flowmeter measurements indicate the greatest quantity of water enters the borehole through fractures near 111-115 ft bls and above $86 \mathrm{ft}$ bls. The heatpulse-flowmeter measurements below $214 \mathrm{ft}$ bls were inconsistent, suggesting effects of nearby transient pumpage.

Table 4. Summary of heatpulse-flowmeter measurements for borehole MG-64 (L-5) at North Penn Area 6 Superfund Site, Lansdale, Montgomery County, Pennsylvania

[gal/min, gallon per minute; <, less than]

\begin{tabular}{ccccc}
\hline $\begin{array}{c}\text { Depth } \\
\text { (feet below } \\
\text { land surface) }\end{array}$ & $\begin{array}{c}\text { Flow rate } \\
\text { (gal/min) } \\
\text { nonpumping } \\
\text { conditions }\end{array}$ & $\begin{array}{c}\text { Flow direction } \\
\text { nonpumping } \\
\text { conditions }\end{array}$ & $\begin{array}{c}\text { Flow rate } \\
\text { (gal/min) } \\
\text { pumping } \\
\text { conditions }\end{array}$ & $\begin{array}{c}\text { Flow direction } \\
\text { pumping } \\
\text { conditions }\end{array}$ \\
\hline 86 & no data & no data & 0.11 & up \\
95 & no data & no data & .10 & up \\
106 & 0.06 & up & .12 & up \\
118 & no data & no data & .03 & up \\
134 & .01 & up & .07 & up \\
154 & no data & no data & .06 & up \\
180 & .01 & up & .04 & up \\
214 & no data & no data & .05 & up \\
288 & .01 & up & .20 & up \\
290 & .01 & up & no data & no data \\
342 & .01 & up & .12 & up \\
376 & .01 & up & .20 & up \\
490 & not reproducible & no data & $<.01$ & no data \\
\hline
\end{tabular}




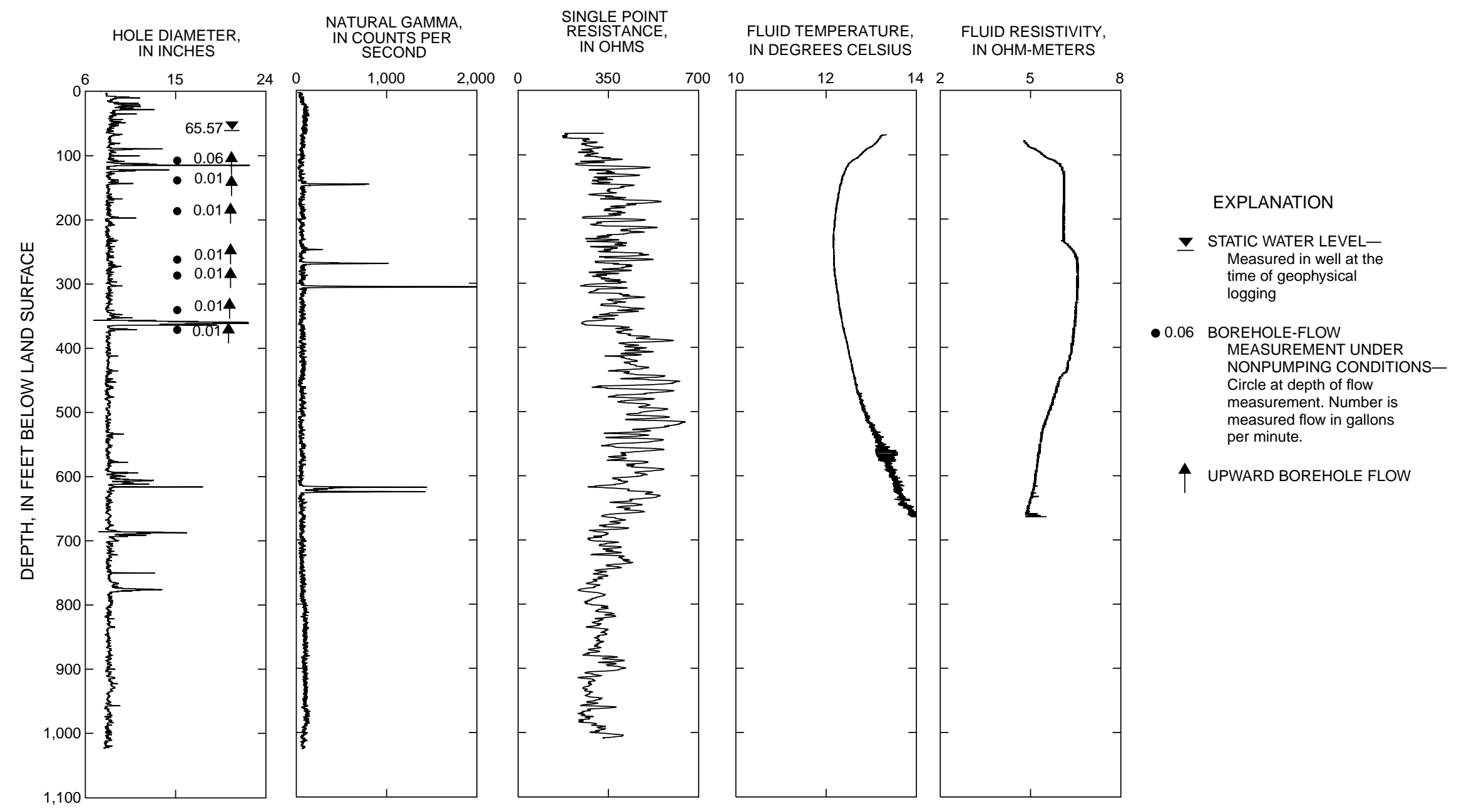

Figure 3. Borehole geophysical logs and direction of nonpumping flow within borehole MG-64 (L-5), North Penn Area 6 Superfund Site, Lansdale, Montgomery County, Pennsylvania. 


\section{MG-67 (L-8)}

The caliper log shows the total depth of the borehole is $294 \mathrm{ft}$ and it is cased with 8-in.-diameter casing to $19 \mathrm{ft}$ bls (fig. 4). The caliper log shows major fracture zones at 24, 72-75, 78-84, and 186-192 ft bls plus other smaller fractures. The static water level was $19.91 \mathrm{ft}$ bls at the time of logging. The natural-gamma log shows thin zones, possibly shale beds, with elevated readings at 75-77, 171-173, and 201-204 ft bls that might be used for stratigraphic correlation of geologic units with other wells. The deviation log shows the borehole deviates from vertical approximately $1.5 \mathrm{ft}$ to the northwest over the total length of the borehole (fig. 5).

The strike and dip of fracture planes intersected by the borehole were obtained from the acoustic televiewer. The results are shown on an equal-area stereonet with single points (poles) plotted in the lower hemisphere at right angles to the fracture planes. These poles indicate that most fracture planes trend northeast-southwest (fig. 6), which is the general strike direction. The greatest concentration of poles are near the center of figure 6 , probably indicating shallow bedding planes. Thirty-four possible bedding planes were identified, 27 dip to the northwest with an average strike and dip of N. $72^{\circ}$ E., $6^{\circ} \mathrm{NW}$., which is nearly coincident with regional strike and dip; 7 shallow planes dip to the southwest with an average strike and dip of N. $38^{\circ} \mathrm{W}$., dipping $6^{\circ} \mathrm{SW}$. Eight high-angle fracture planes were identified in the borehole, with an average strike of N. $10^{\circ} \mathrm{W}$. and dipping $23^{\circ} \mathrm{NE}$.

The fluid-temperature and fluid-resistivity logs show a slight change in slope at $54 \mathrm{ft}$ bls that correlates to a small fracture at approximately $54 \mathrm{ft}$ bls on the caliper log and video log. The fluid-temperature log shows a small change in slope at $150 \mathrm{ft}$ bls. Also, the fluid-temperature log shows a small temperature gradient from 54 to $150 \mathrm{ft}$ bls suggesting a zone of vertical borehole flow. Under nonpumping conditions, the heatpulse flowmeter measured downward flow at 65 and $114 \mathrm{ft}$ bls (table 5). A pipe was seen in the borehole on the video log at $120 \mathrm{ft}$ bls that prevented heatpulse-flowmeter measurements below that depth. A submersible pump was placed at $21 \mathrm{ft} \mathrm{bls,} \mathrm{and} \mathrm{the} \mathrm{well} \mathrm{was} \mathrm{pumped} \mathrm{at} \mathrm{less} \mathrm{than} 1.5 \mathrm{gal} / \mathrm{min}$. The water level in the well stabilized after $12 \mathrm{~min}$ of pumping and declined only $0.43 \mathrm{ft}$ after a total of $39 \mathrm{~min}$ of pumping. Under pumping conditions, the heatpulse flowmeter measured upward flow at 46, 65, and $114 \mathrm{ft} \mathrm{bls}$. The suite of borehole geophysical logs and heatpulse-flowmeter measurements indicate the greatest quantity of water enters the borehole through bedding fractures at $24-30 \mathrm{ft}$ bls. Additional water is produced at depths greater than $114 \mathrm{ft}$ bls; smaller quantities of water enter the borehole through fractures at about 54 or $58 \mathrm{ft}$ bls and $72-75 \mathrm{ft}$ bls.

Table 5. Summary of heatpulse-flowmeter measurements for borehole MG-67 (L-8) at North Penn Area 6 Superfund Site, Lansdale, Montgomery County, Pennsylvania

[gal/min, gallon per minute]

\begin{tabular}{ccccc}
\hline $\begin{array}{c}\text { Depth } \\
\text { (feet below } \\
\text { land surface) }\end{array}$ & $\begin{array}{c}\text { Flow rate } \\
\text { (gal/min) } \\
\text { nonpumping } \\
\text { conditions }\end{array}$ & $\begin{array}{c}\text { Flow direction } \\
\text { nonpumping } \\
\text { conditions }\end{array}$ & $\begin{array}{c}\text { Flow rate } \\
\text { (gal/min) } \\
\text { pumping } \\
\text { conditions }\end{array}$ & $\begin{array}{c}\text { Flow direction } \\
\text { pumping } \\
\text { conditions }\end{array}$ \\
\hline 46 & no data & no data & 0.35 & up \\
65 & 0.04 & down & .31 & up \\
114 & .07 & down & .20 & up \\
\hline
\end{tabular}




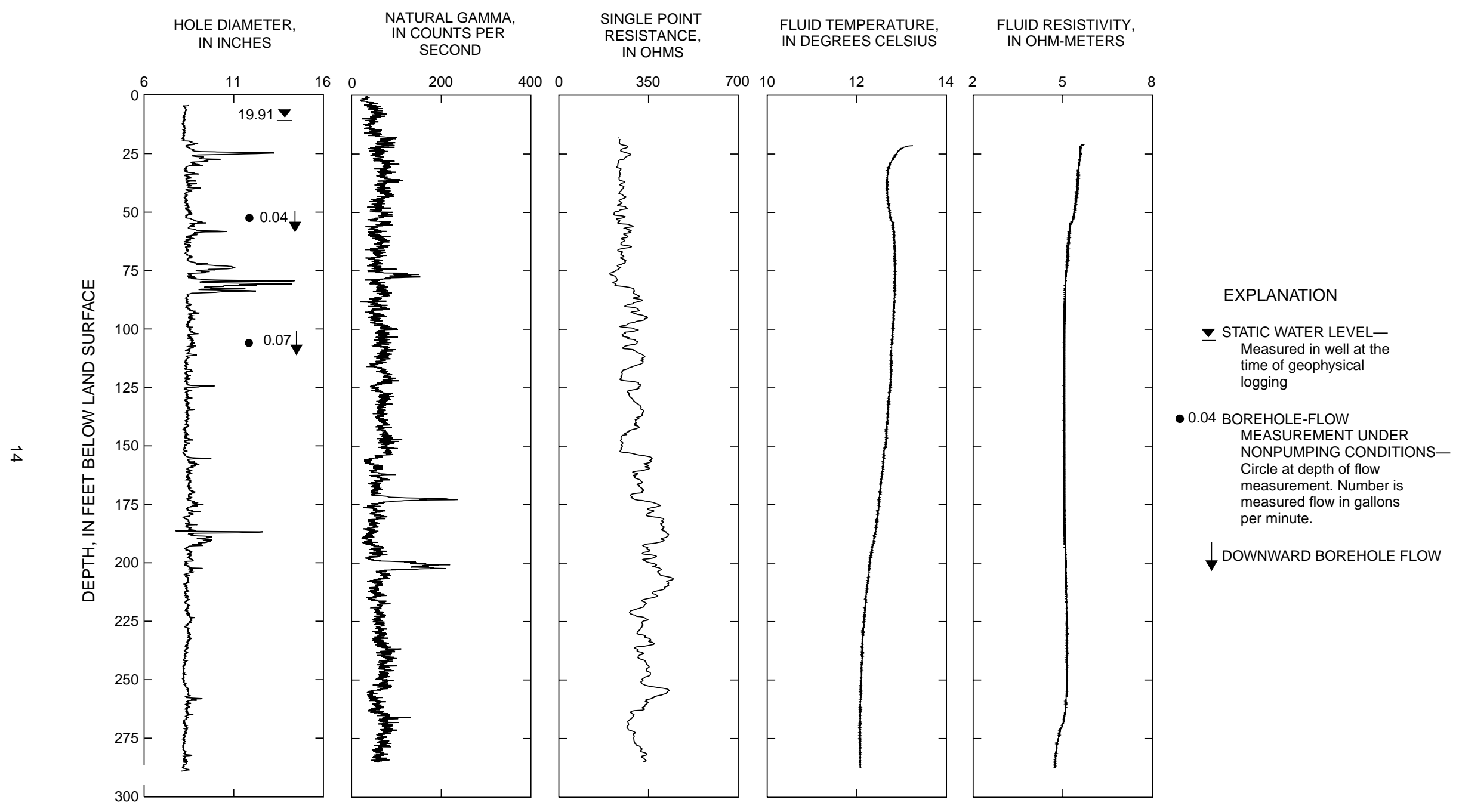

Figure 4. Borehole geophysical logs and direction of nonpumping flow within borehole MG-67 (L-8), North Penn Area 6 Superfund Site, Lansdale, Montgomery County, Pennsylvania. 


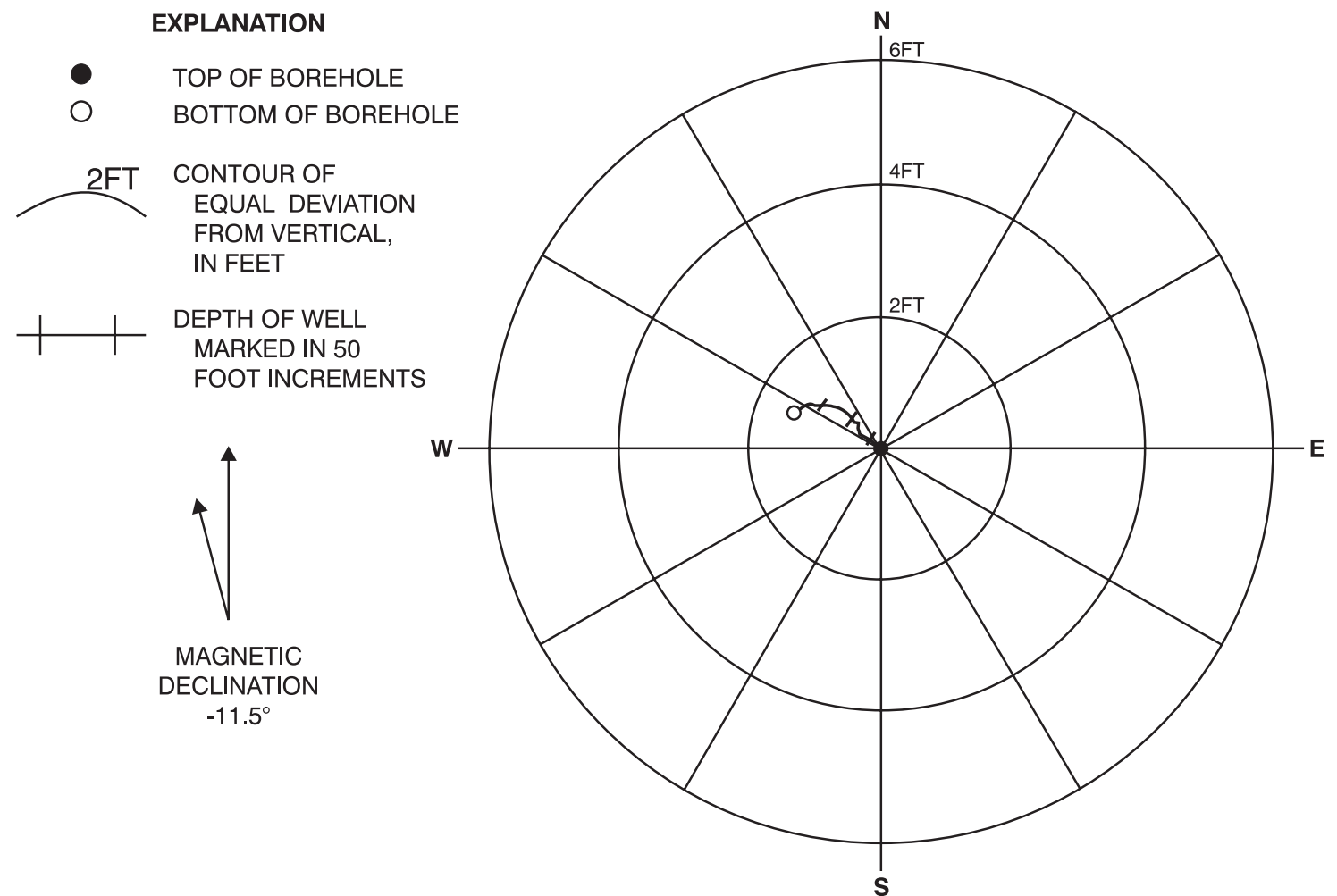

Figure 5. Magnitude and direction of deviation from vertical of borehole MG-67 (L-8).

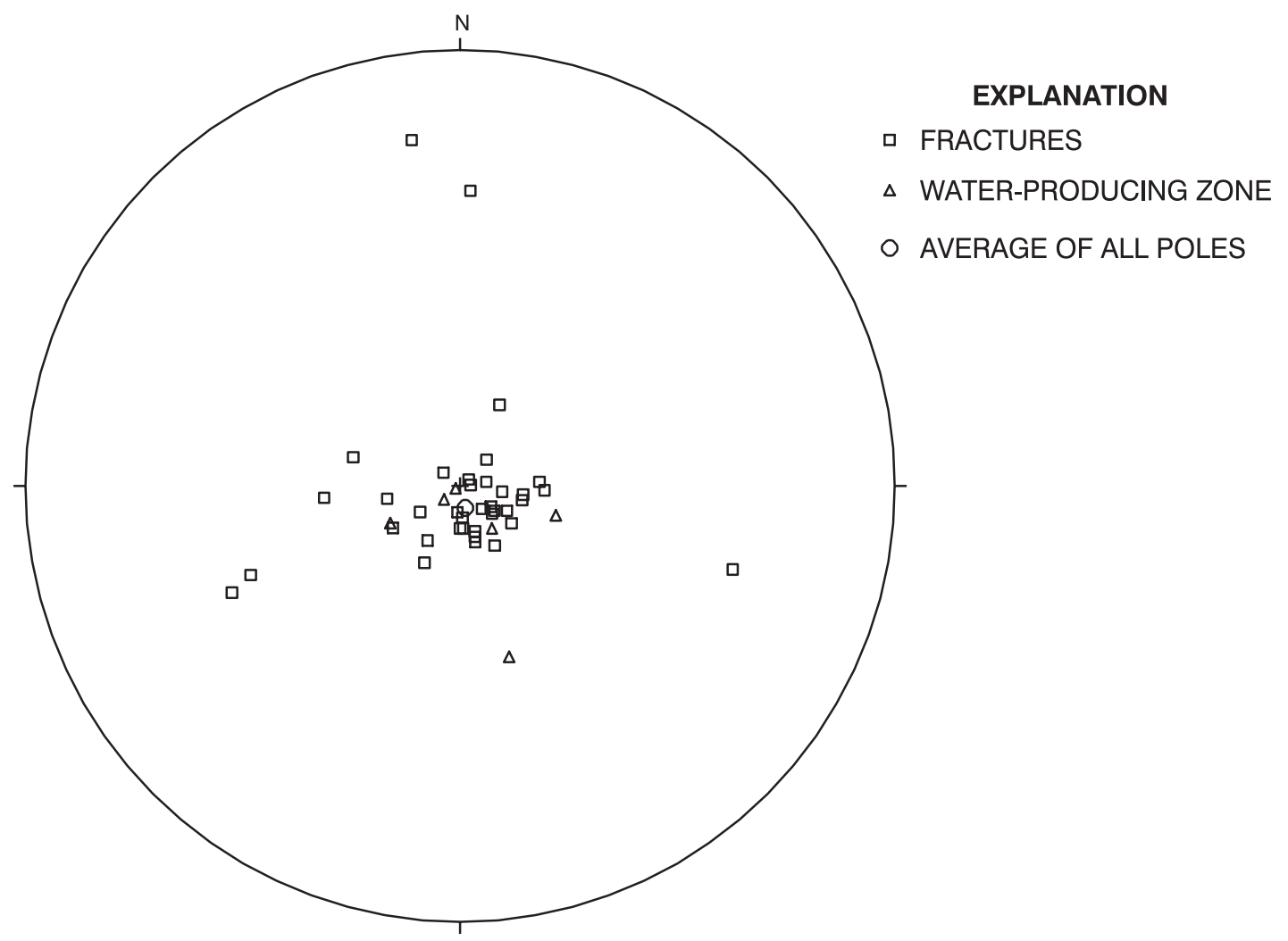

Figure 6. Equal-area lower hemisphere, stereographic projection of poles perpendicular to fracture planes in borehole MG-67 (L-8). 


\section{MG-68 (L-9)}

The caliper log shows the total depth of the borehole is $460 \mathrm{ft}$ and it is cased with 14-in.-diameter casing to $9 \mathrm{ft}$ bls (fig. 7). The caliper log shows a decrease in borehole diameter from $14 \mathrm{in}$. to $10 \mathrm{in}$. at $50 \mathrm{ft}$ bls and $10 \mathrm{in.} \mathrm{to} 8 \mathrm{in}$. beginning at $250 \mathrm{ft}$ bls. The caliper log shows major fractures at 10, 18-20, 24-30, 44-50, 57-61, 106-109, 128-140, 169-171, and 414-418 ft bls plus numerous other fractures throughout the open-hole interval. The caliper log shows constrictions at 131, 133, 139, 409, 414, 417, 419, and 448-460 ft bls. These constrictions may be caused by blocks of fractured mudstone or siltstone shifting in the borehole over time. The static water level at the time of logging was $41.30 \mathrm{ft}$ bls. The natural-gamma log shows a shale unit with elevated gamma readings at 417-421 ft bls (fig. 7) that might be used for stratigraphic correlation of geologic units with other wells. The deviation log shows the borehole deviates from vertical approximately $3 \mathrm{ft}$ to the south-southeast over the total length of the borehole (fig. 8).

The strike and dip of fracture planes were obtained from the acoustic televiewer. The results are shown on an equal-area stereonet with single points (poles) plotted in the lower hemisphere at right angles to the fracture planes. These poles indicate that most fracture planes trend northeast-southwest (fig. 9). The greatest concentration of poles are near the center of figure 9, again indicating that the planes are parallel to bedding. Twenty possible bedding planes were identified, 16 dip to the northwest with an average strike and dip of N. $84^{\circ}$ E., $9^{\circ} \mathrm{NW}$., that is nearly coincident with the regional strike and dip; 4 shallow planes dip to the southeast with an average strike and dip of N. $84^{\circ} \mathrm{W} ., 7^{\circ} \mathrm{SW}$. Thirteen high-angle fracture planes were identified in the borehole. A plane representative of the average of these high-angle fractures would have a strike and dip of N. $73^{\circ}$ E., $75^{\circ} \mathrm{NE}$.

The fluid-resistivity and fluid-temperature logs show a change in slope at $270-280 \mathrm{ft}$ bls that is in proximity to a fracture at $280 \mathrm{ft}$ bls shown on the caliper log. Under nonpumping conditions, the heatpulse flowmeter measured upward borehole flow at 70, 120, 152, 270, 310, 350, 370, 380, 406, and $426 \mathrm{ft}$ bls, downward flow at $270 \mathrm{ft} \mathrm{bls,} \mathrm{and} \mathrm{no} \mathrm{flow} \mathrm{at} 220$ and $245 \mathrm{ft}$ bls (table 6). A submersible pump was then placed at $55 \mathrm{ft}$ bls, and the borehole was pumped at $3.75 \mathrm{gal} / \mathrm{min}$. The nonpumping water level in the well was $41.84 \mathrm{ft}$ bls. The water level in the borehole declined $0.83 \mathrm{ft}$ after 1 hour and $17 \mathrm{~min}$. Under pumping conditions, the heatpulse flowmeter measured upward borehole flow at 70, 100, 120, and $150 \mathrm{ft}$ bls, downward flow at $270 \mathrm{ft}$ bls, and no flow at 220 and $245 \mathrm{ft}$ bls. Under nonpumping conditions, the suite of geophysical logs and heatpulse-flowmeter measurements indicate water enters the borehole through fractures at 108-110, 169-171, 321-323, 361-371, and below $426 \mathrm{ft}$ bls, moves upward, and exits the borehole through the fractures at 284-288 and above $70 \mathrm{ft}$ bls. Also, water enters the borehole through fractures at 249-255 ft bls, moves downward, and exits the borehole through fractures at 284-288 ft bls. Under shallow pumping conditions, the suite of geophysical logs and heatpulse-flowmeter measurements indicate the greatest quantity of water enters the borehole through the fractures near 108-110 and above $70 \mathrm{ft}$ bls. 


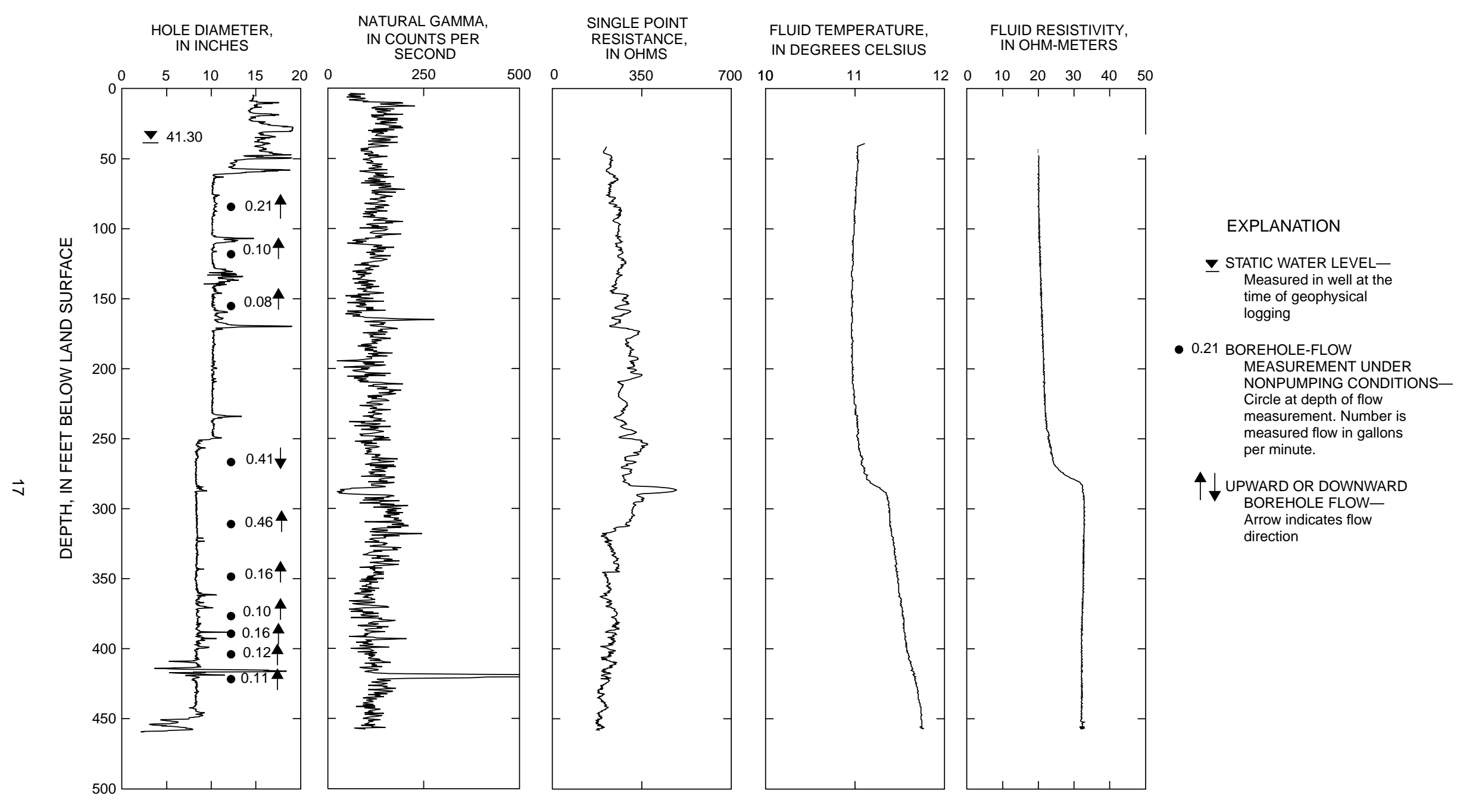

Figure 7. Borehole geophysical logs and direction of nonpumping flow within borehole MG-68 (L-9), North Penn Area 6 Superfund Site, Lansdale, Montgomery County, Pennsylvania. 


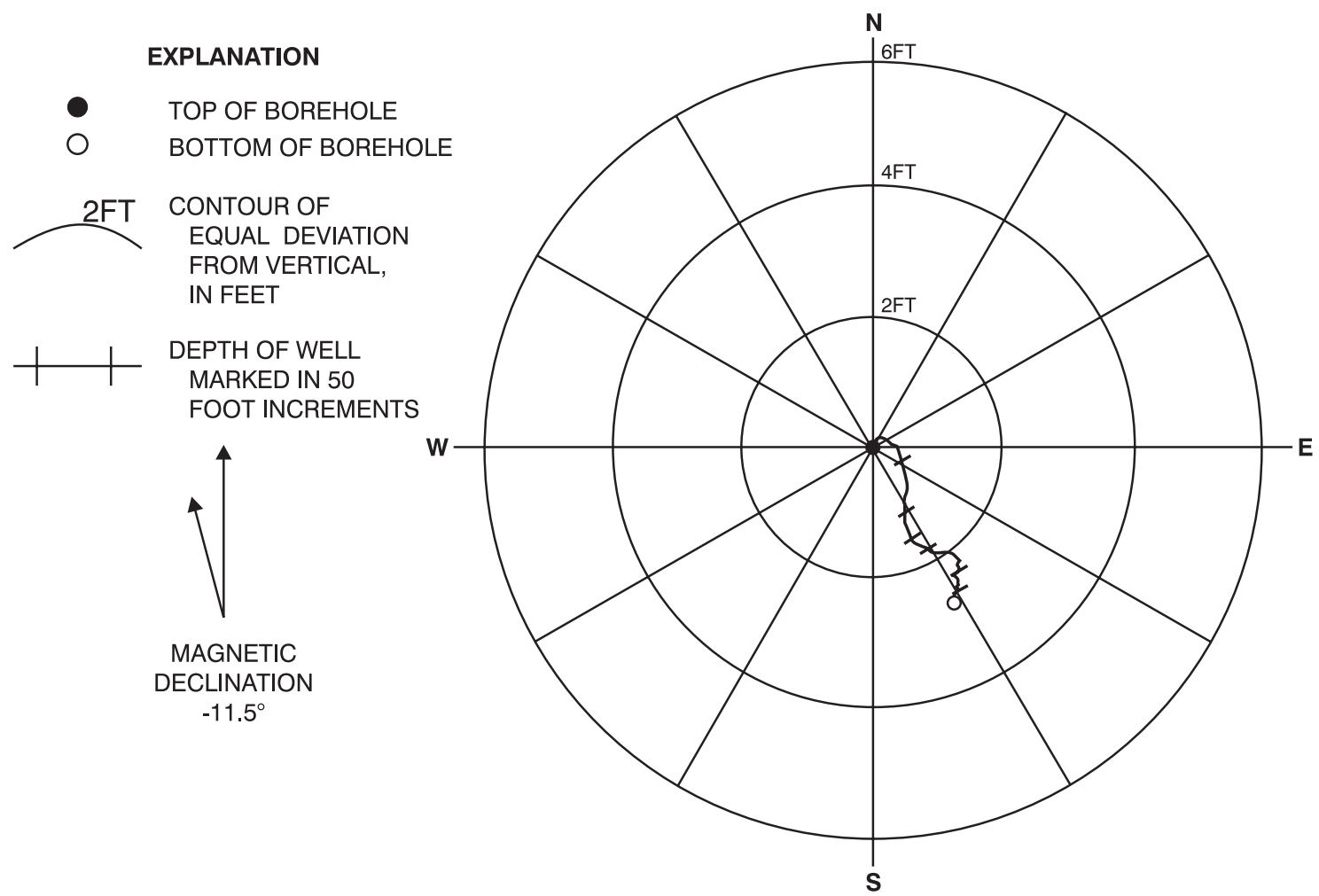

Figure 8. Magnitude and direction of deviation from vertical of borehole MG-68 (L-9).

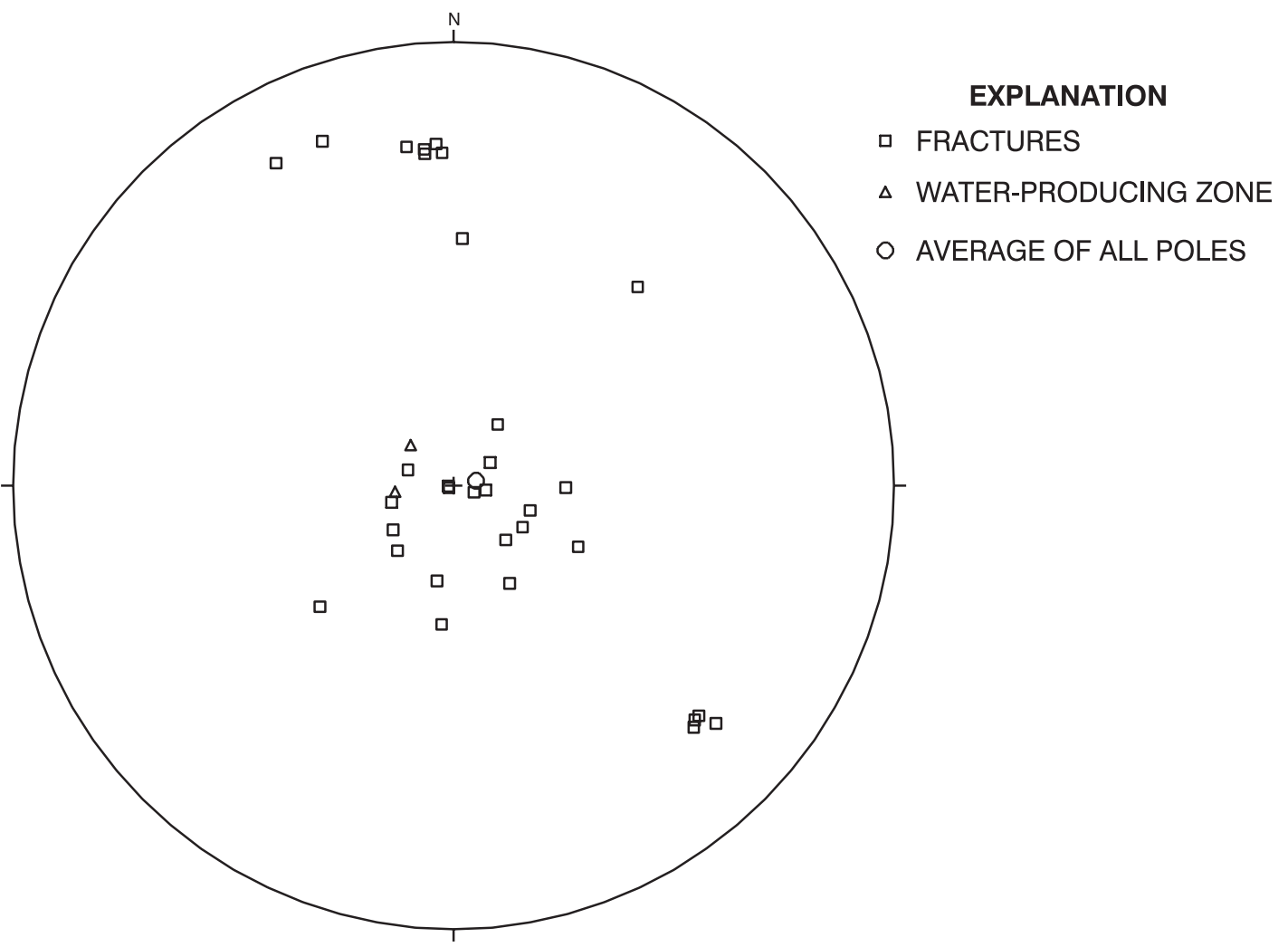

Figure 9. Equal-area lower hemisphere, stereographic projection of poles perpendicular to fracture planes in borehole MG-68 (L-9). 
Table 6. Summary of heatpulse-flowmeter measurements for borehole MG-68 (L-9) at North Penn Area 6 Superfund Site, Lansdale, Montgomery County, Pennsylvania

[gal/min, gallon per minute]

\begin{tabular}{ccccc}
\hline $\begin{array}{c}\text { Depth } \\
\text { (feet below } \\
\text { land surface) }\end{array}$ & $\begin{array}{c}\text { Flow rate } \\
\text { (gal/min) } \\
\text { nonpumping } \\
\text { conditions }\end{array}$ & $\begin{array}{c}\text { Flow direction } \\
\text { nonpumping } \\
\text { conditions }\end{array}$ & $\begin{array}{c}\text { Flow rate } \\
\text { (gal/min) } \\
\text { pumping } \\
\text { conditions }\end{array}$ & $\begin{array}{c}\text { Flow direction } \\
\text { pumping } \\
\text { conditions }\end{array}$ \\
\hline 70 & 0.21 & up & 0.32 & up \\
100 & no data & no data & .47 & up \\
120 & .10 & up & .15 & up \\
150 & no data & no data & up \\
152 & .08 & up & no data & no data \\
220 & no flow & not determined & no flow & not determined \\
245 & no flow & not determined & .16 & not determined \\
270 & .41 & up & no data & no data \\
310 & .46 & up & no data & no data \\
350 & .16 & up & no data & no data \\
370 & .10 & up & no data & no data \\
380 & .16 & up & no data & no data \\
406 & .12 & up & no data & no data \\
\hline
\end{tabular}




\section{MG-69 (L-10)}

The caliper log shows the total depth of the borehole is $251 \mathrm{ft}$ and it is cased with 8-in.-diameter casing to $39 \mathrm{ft}$ bls (fig. 10). The caliper log shows major fractures at 70-72, 79-80, 89-91, 109-113, 163, and $172 \mathrm{ft}$ bls plus numerous other fractures throughout the open-hole interval. The static water level at the time of logging was $44.66 \mathrm{ft}$ bls. The fluid-resistivity and fluid-temperature logs show changes in slope at 70, 127, and $210 \mathrm{ft}$ bls (fig. 10) that could indicate water-producing or water-receiving zones. Under nonpumping conditions, the heatpulse flowmeter measured upward borehole flow at 52, 58, 76, 83, 106, 120, 144, 194, 218, and $234 \mathrm{ft}$ bls (table 7). A submersible pump was placed at $60 \mathrm{ft}$ bls, and the borehole was pumped at approximately $1 \mathrm{gal} / \mathrm{min}$. The water level in the borehole declined $0.04 \mathrm{ft}$ after 1 hour and $41 \mathrm{~min}$, which means that all flow measured within the borehole is contributed from the aquifer. Under pumping conditions, the heatpulse flowmeter measured upward borehole flow at 74, 83, 106, 120, 132, 144, 168, 194, 218 , and $234 \mathrm{ft}$ bls. Under nonpumping conditions, the suite of geophysical logs and heatpulse-flowmeter measurements indicate water enters the borehole through fractures at 109-113, 125-129, 158-162, and 238$242 \mathrm{ft} \mathrm{bls}$, moves upward, and exits the borehole through the fractures at 47, 62-72, 80, and 89-91 ft bls. Under pumping conditions, the suite of geophysical logs and heatpulse-flowmeter measurements indicate approximate equal quantities of water enter the borehole through fractures at 125-129 and 158-162 ft bls and a small quantity from 238-242 ft bls. The most productive zones in the borehole are between 79$163 \mathrm{ft} \mathrm{bls.}$

Table 7. Summary of heatpulse-flowmeter measurements for borehole MG-69 (L-10), North Penn Area 6 Superfund Site, Lansdale, Montgomery County, Pennsylvania

[gal/min, gallon per minute]

\begin{tabular}{rcccc}
\hline $\begin{array}{c}\text { Depth } \\
\text { (feet below } \\
\text { land surface) }\end{array}$ & $\begin{array}{c}\text { Flow rate } \\
\text { (gal/min) } \\
\text { nonpumping } \\
\text { conditions }\end{array}$ & $\begin{array}{c}\text { Flow direction } \\
\text { nonpumping } \\
\text { conditions }\end{array}$ & $\begin{array}{c}\text { Flow rate } \\
\text { (gal/min) } \\
\text { pumping } \\
\text { conditions }\end{array}$ & $\begin{array}{c}\text { Flow direction } \\
\text { pumping } \\
\text { conditions }\end{array}$ \\
\hline 52 & 0.07 & up & no data & no data \\
58 & .08 & up & no data & up \\
74 & no data & no data & 1.2 & no data \\
76 & .19 & up & no data & up \\
83 & .53 & up & 1.2 & up \\
106 & .86 & up & 1.1 & up \\
120 & .75 & up & 1.0 & up \\
132 & no data & no data & .50 & up \\
144 & $.32-.50$ & up & .54 & up \\
194 & no data & no data & .06 & up \\
218 & .06 & up & .05 & up \\
\hline
\end{tabular}

\section{MG-72 (L-13)}

The caliper log shows the total depth of the borehole is $298 \mathrm{ft}$ and it is cased with 10 -in.-diameter casing to $41.5 \mathrm{ft}$ bls (fig. 11). The caliper log shows major fractures zones at 41-50, 66, 79-86 132-141, and 165$169 \mathrm{ft}$ bls plus numerous smaller fractures. The static water level at the time of logging was $65.63 \mathrm{ft}$ bls. The natural-gamma log shows a thin unit, possibly a shale bed, at $287-289 \mathrm{ft}$ bls that might be used for stratigraphic correlation of geologic units with other wells. The fluid-temperature log shows changes in slope at 73, 85, and $250 \mathrm{ft}$ bls that correlate to fractures at 71, 79-86, and $253 \mathrm{ft}$ bls on the caliper log. The fluid-temperature log shows almost no temperature gradient from 92 to $253 \mathrm{ft}$ bls indicating a zone of vertical borehole flow. A slug of high conductance fluid was injected at $165 \mathrm{ft}$ bls and was traced moving down at a rate of $12 \mathrm{gal} / \mathrm{min}$. This well was not pumped or traced with the heatpulse flowmeter; the large diameter borehole and high nonpumping flow rate would have adversely effected the process. The suite of 


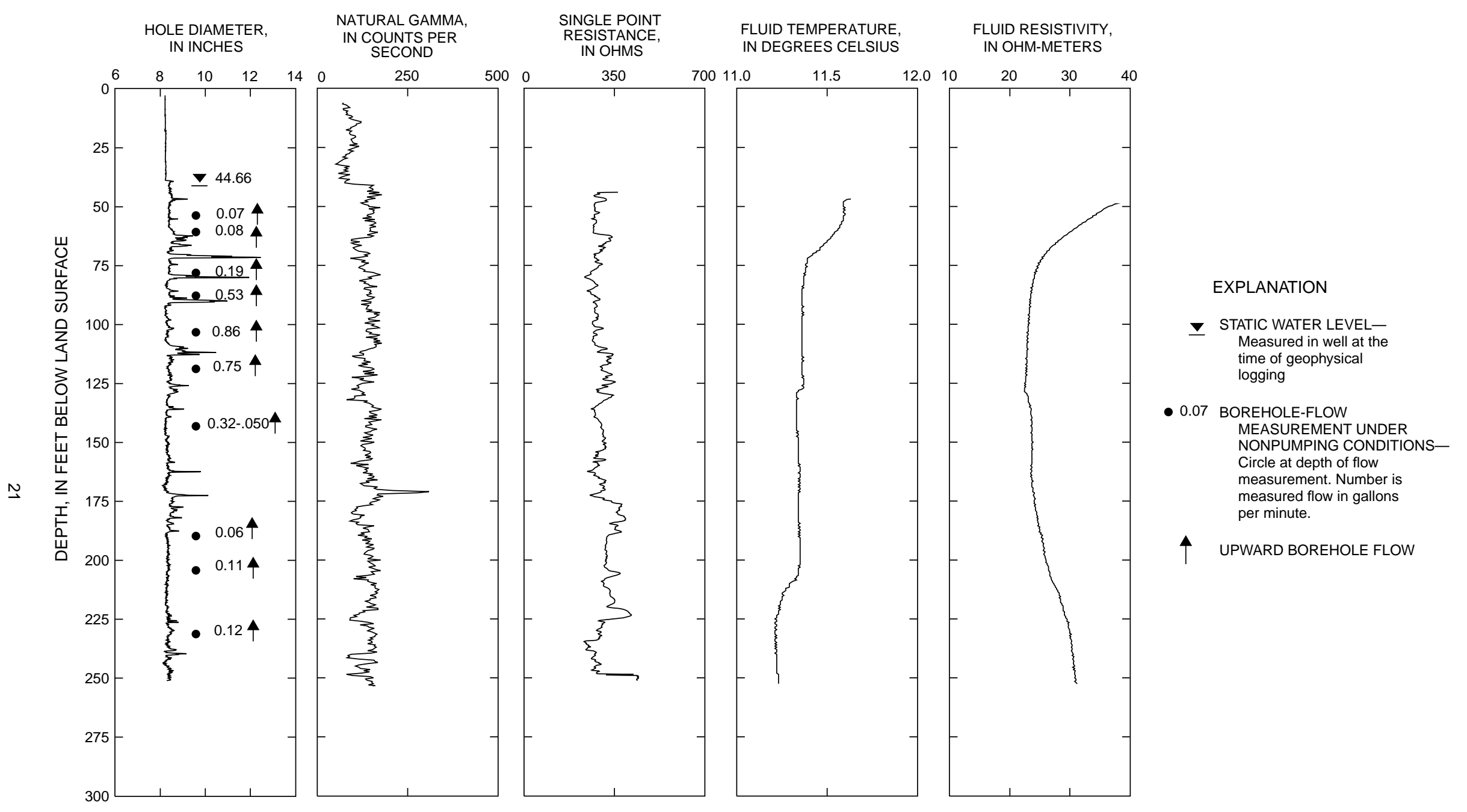

Figure 10. Borehole geophysical logs and direction of nonpumping flow within borehole MG-69 (L-10), North Penn Area 6 Superfund Site, Lansdale, Montgomery County, Pennsylvania. 


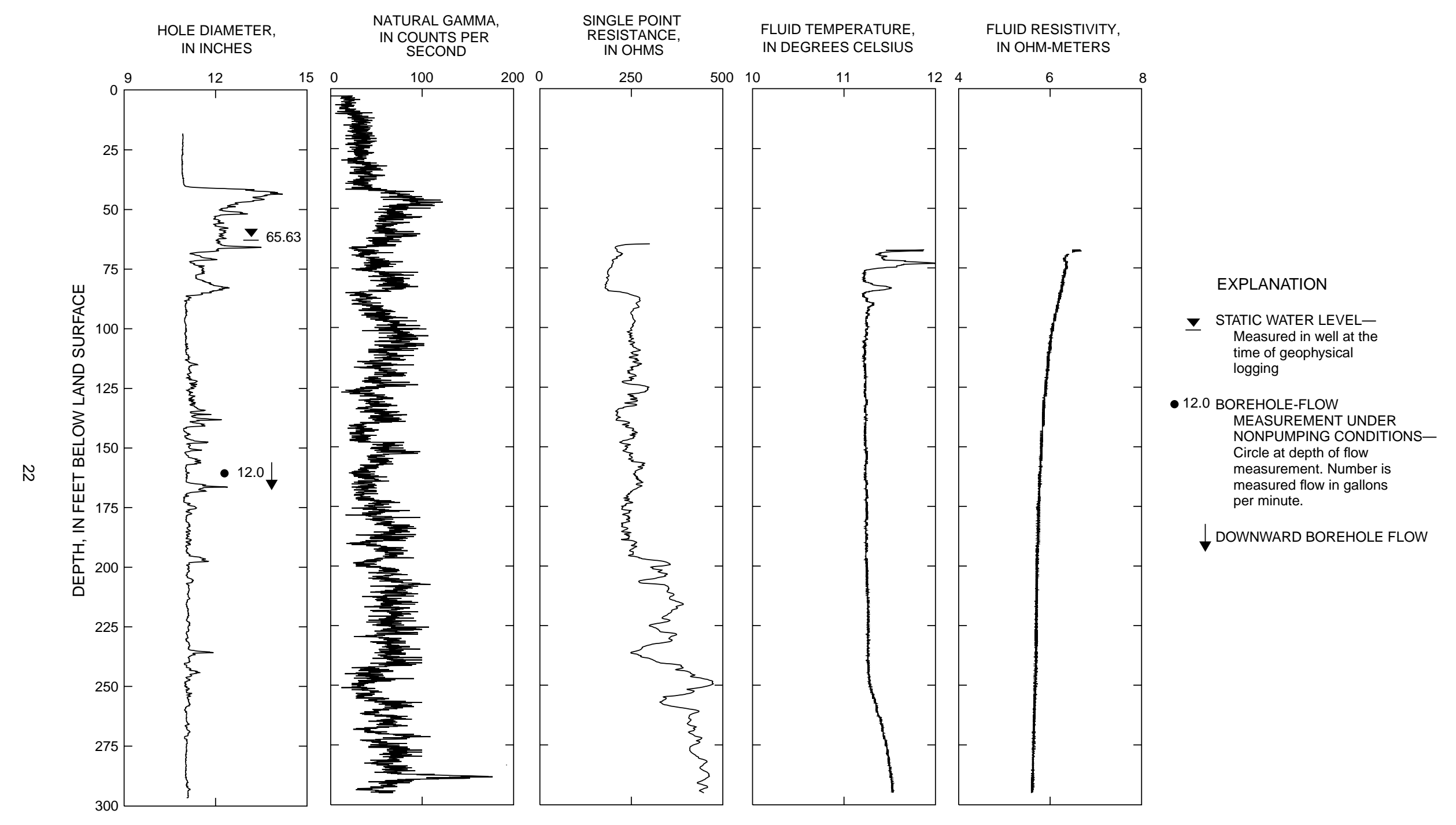

Figure 11. Borehole geophysical logs and direction of nonpumping flow within borehole MG-72 (L-13), North Penn Area 6 Superfund Site, Lansdale, Montgomery County, Pennsylvania. 
borehole geophysical logs and brine-trace data indicate that, under nonpumping conditions, water enters the borehole through fractures at 71 and $79-86 \mathrm{ft}$ bls, moves down at a rate of $12 \mathrm{gal} / \mathrm{min}$, and exits the borehole through fractures at approximately $250 \mathrm{ft}$ bls. The well is near pumping production wells that may affect ground-water flow locally.

\section{MG-76 (L-17)}

The caliper $\log$ shows the total depth of the borehole is $367 \mathrm{ft}$ and it is cased with 12-in.-diameter casing to $40 \mathrm{ft}$ bls (fig. 12). The caliper log shows major fractures at 42-48, 57, 94, 183, 213, 228, 230-232, 302-304, 300-311, and 342-344 ft bls plus numerous other fractures throughout the open-hole interval. The caliper log shows a reduction in borehole diameter at $286 \mathrm{ft}$ bls from $12 \mathrm{in.} \mathrm{to} 10 \mathrm{in}$. The natural-gamma log shows a shale unit with elevated gamma readings at 32-34 and 299-301 ft bls (fig. 12) that might be used for stratigraphic correlation of geologic units with other wells. The fluid-temperature log shows changes in slope at 52, 100, and $230 \mathrm{ft}$ bls (fig. 12) that approximately correlate to some major fractures shown on the caliper log. The fluid-resistivity log shows a change in slope at $100 \mathrm{ft}$ bls that could indicate a waterproducing zone. The fluid-temperature log shows almost no temperature gradient from 50 to $230 \mathrm{ft}$ bls indicating a zone of possible vertical borehole flow. Under nonpumping conditions, the suite of geophysical logs indicates water may enter the borehole through the fractures at 42-51 and near $100 \mathrm{ft}$ bls, possibly move downward, and exit the borehole through the fracture at $228-232 \mathrm{ft}$ bls. No measurements of vertical flow were made in the well. The well is near pumping wells that may affect ground-water flow locally. 


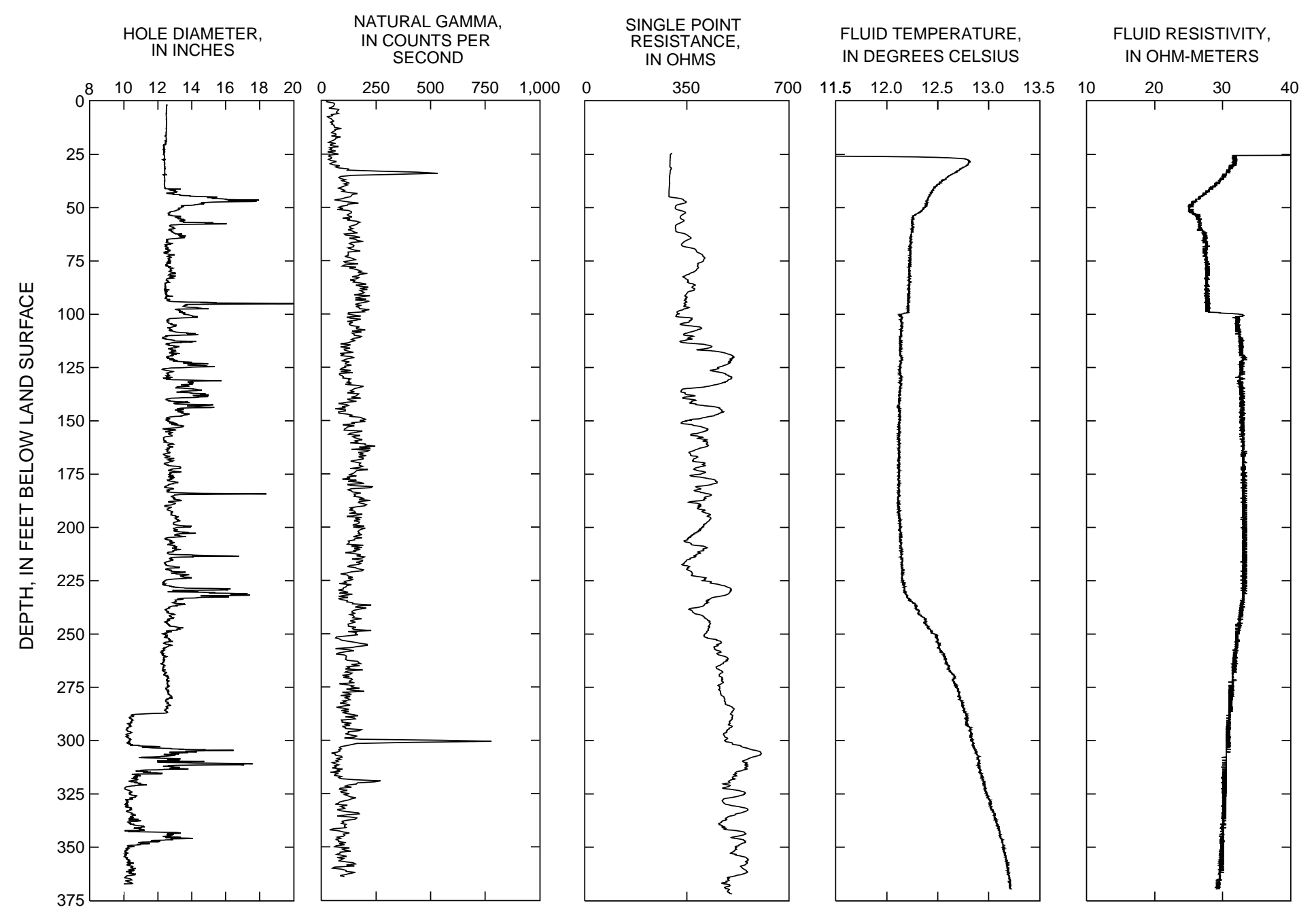

Figure 12. Borehole geophysical logs for borehole MG-76 (L-17), North Penn Area 6 Superfund Site, Lansdale, Montgomery County, Pennsylvania. 


\section{MG-79 (LB-4)}

The caliper log shows the total depth of the borehole is $280 \mathrm{ft}$ and it is cased with 6-in.-diameter casing to $7 \mathrm{ft}$ bls (fig. 13). The caliper log shows major fracture zones at 79, 91, and $99 \mathrm{ft}$ bls plus numerous smaller fractures throughout the open-hole interval. The static water level at the time of logging was $54.73 \mathrm{ft} \mathrm{bls.}$ The fluid-temperature log shows changes in slope at 75, 83, 106, 124, and $166 \mathrm{ft}$ bls. The fluid-temperature $\log$ shows a small temperature gradient from 124 to $166 \mathrm{ft}$ bls, suggesting a zone of slight vertical borehole flow. Under nonpumping conditions, the heatpulse flowmeter measured slight downward flow at 68, 87, 132, and $150 \mathrm{ft}$ bls (table 8). However, values for all measured intervals were exactly the same, suggesting that the oily substance in the well may have adversely affected the probe. Heatpulse flowmetering while pumping was not conducted because of the presence of the oily substance in the well. The suite of geophysical logs indicates the possibility of minor vertical flow during nonpumping conditions between fractures near 124 and $166 \mathrm{ft}$ bls.

Table 8. Summary of heatpulse-flowmeter measurements for borehole MG-79 (LB-4) at North Penn Area 6 Superfund Site, Lansdale, Montgomery County, Pennsylvania

[gal/min, gallon per minute]

\begin{tabular}{ccc}
\hline $\begin{array}{c}\text { Depth } \\
\text { (feet below } \\
\text { land surface) }\end{array}$ & $\begin{array}{c}\text { Flow rate } \\
\text { (gal/min) } \\
\text { nonpumping } \\
\text { conditions }\end{array}$ & $\begin{array}{c}\text { Flow direction } \\
\text { nonpumping } \\
\text { conditions }\end{array}$ \\
\hline 68 & 0.02 & down \\
87 & .02 & down \\
132 & .02 & down \\
150 & .02 & down \\
\hline
\end{tabular}



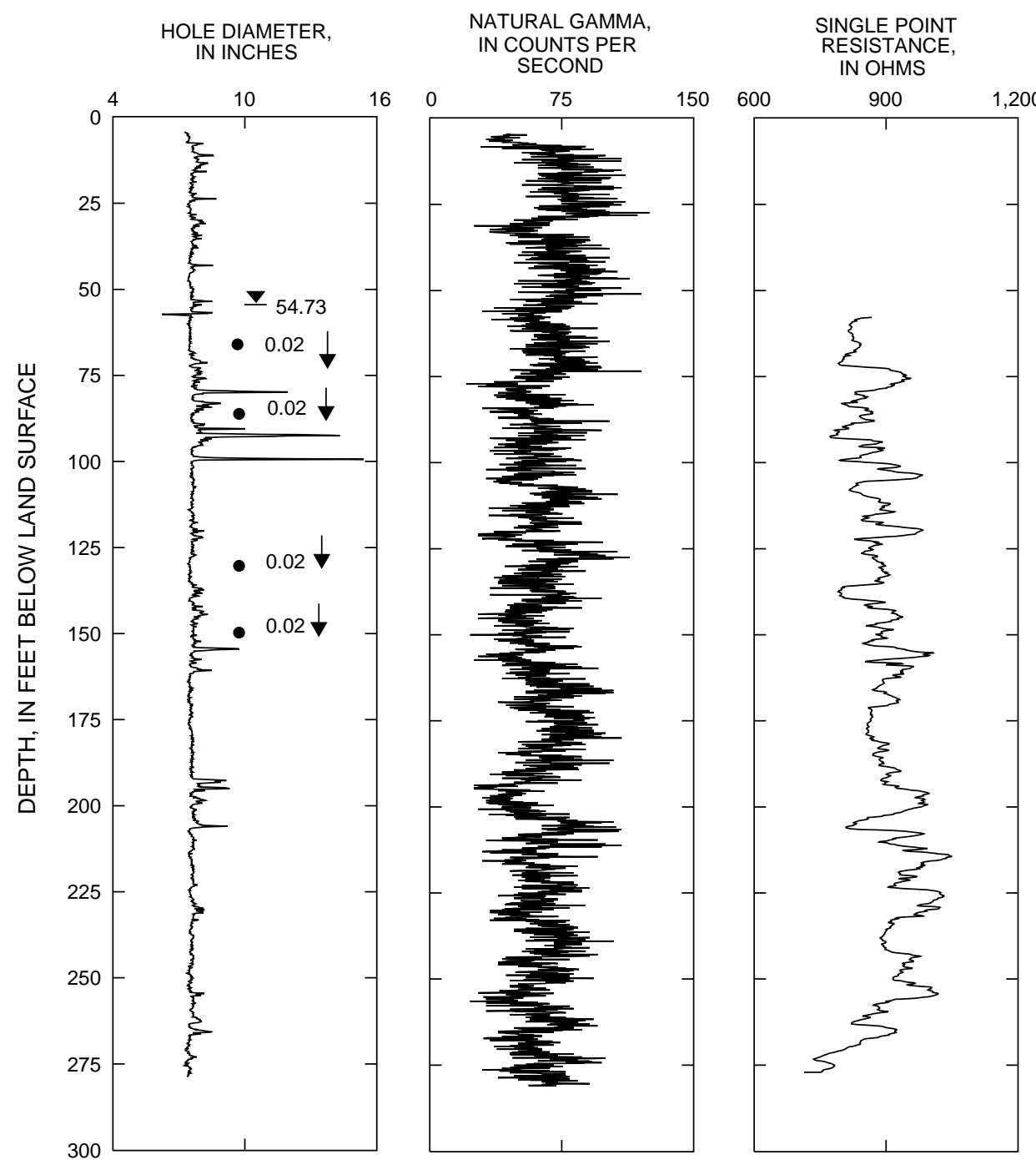

FLUID TEMPERATURE,
IN DEGREES CELSIUS

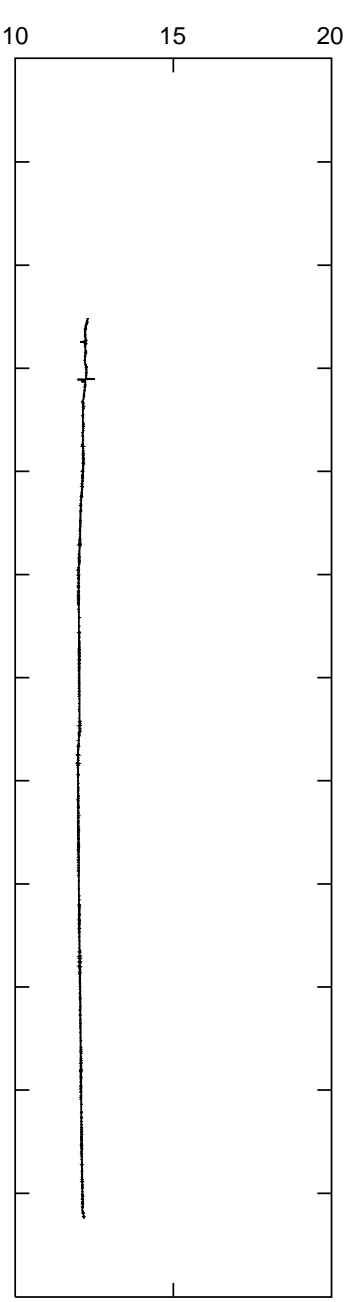

\section{EXPLANATION}

$\checkmark$ STATIC WATER LEVELMeasured in well at the time of geophysical logging

- 0.02 BOREHOLE-FLOW

MEASUREMENT UNDER NONPUMPING CONDITIONS-

Circle at depth of flow

measurement. Number is

measured flow in gallons

per minute.

$\downarrow$ DOWNWARD BOREHOLE FLOW

Figure 13. Borehole geophysical logs and direction of nonpumping flow within borehole MG-79 (LB-4), North Penn Area 6 Superfund Site,

Lansdale, Montgomery County, Pennsylvania. 


\section{MG-80 (Lansdale Borough)}

The caliper log shows the total depth of the borehole is $258 \mathrm{ft}$ and it is cased with 8-in.-diameter casing to $138 \mathrm{ft}$ bls (fig. 14). The caliper log shows fractures at 144-154, 195-196, 214-215, 240-242, and 253-258 ft bls plus numerous other fractures throughout the open-hole interval. The caliper log shows a change in borehole diameter at $185 \mathrm{ft}$ bls, probably indicating that casing was intended to be set to that depth. The static water level at the time of logging was $13.29 \mathrm{ft}$ bls. The natural-gamma log shows shale units with elevated gamma readings at 200-202 and 230-233 ft bls that might be used for stratigraphic correlation of geologic units with other wells. The deviation log shows the borehole deviates from vertical approximately $3.5 \mathrm{ft}$ to the northwest over the total length of the borehole (fig. 15).

The strike and dip of fracture planes were obtained from the acoustic televiewer. The results are shown on an equal-area stereonet with single points (poles) plotted in the lower hemisphere at right angles to the fracture planes. These poles indicate that most fracture planes trend northeast-southwest (fig. 16). The greatest concentration of poles are near the center of figure 16, probably indicating shallow bedding planes. Eight possible bedding planes were identified with an average strike and dip of N. $48^{\circ} \mathrm{W} ., 8^{\circ} \mathrm{SW}$. Five highangle fracture planes were identified in the borehole with an average strike and dip of N. $70^{\circ}$ E., $65^{\circ} \mathrm{NW}$. One fracture plane dips to the southwest with a strike and dip of N. $76^{\circ} \mathrm{W} ., 10^{\circ} \mathrm{SW}$.

The fluid-resistivity and fluid-temperature logs do not indicate any water-producing zones within the borehole. Under nonpumping conditions, the heatpulse flowmeter measured upward borehole flow at 170, $192,206,224,234$, and $248 \mathrm{ft}$ bls (table 9). A submersible pump was placed at $50 \mathrm{ft}$ bls, and the borehole was pumped at approximately $1 \mathrm{gal} / \mathrm{min}$. The water level in the borehole declined $0.51 \mathrm{ft}$ after 1 hour and 19 min before stabilizing. Under pumping conditions, the heatpulse flowmeter measured upward borehole flow at 130, 192, 206, 224, 234, and $248 \mathrm{ft}$ bls. Under nonpumping conditions, the suite of geophysical logs and heatpulse-flowmeter measurements indicate water enters the borehole through the fracture at 253-258 $\mathrm{ft}$ bls, moves upward, and exits the borehole through fractures at 144-154 ft bls. Under pumping conditions, the suite of geophysical logs and heatpulse-flowmeter measurements indicate the greatest quantity of water enters the borehole through fractures at 144-154 ft bls.

Table 9. Summary of heatpulse-flowmeter measurements for borehole MG-80 (Lansdale Borough) at North Penn Area 6 Superfund Site, Lansdale, Montgomery County, Pennsylvania

[gal/min, gallon per minute]

\begin{tabular}{ccccc}
\hline $\begin{array}{c}\text { Depth } \\
\text { feet below } \\
\text { land surface) }\end{array}$ & $\begin{array}{c}\text { Flow rate } \\
\text { (gal/min) } \\
\text { nonpumping } \\
\text { conditions }\end{array}$ & $\begin{array}{c}\text { Flow direction } \\
\text { nonpumping } \\
\text { conditions }\end{array}$ & $\begin{array}{c}\text { Flow rate } \\
\text { (gal/min) } \\
\text { pumping } \\
\text { conditions }\end{array}$ & $\begin{array}{c}\text { Flow direction } \\
\text { pumping } \\
\text { conditions }\end{array}$ \\
\hline 130 & no data & no data & ${ }^{1} 0.98$ & up \\
170 & 0.23 & up & no data & no data \\
192 & .20 & up & .07 & up \\
206 & .18 & up & .07 & up \\
224 & .25 & up & .08 & up \\
234 & .25 & up & .08 & up \\
248 & .16 & up & & up \\
\hline
\end{tabular}

${ }^{1}$ Measured inside casing as a calibration check. 


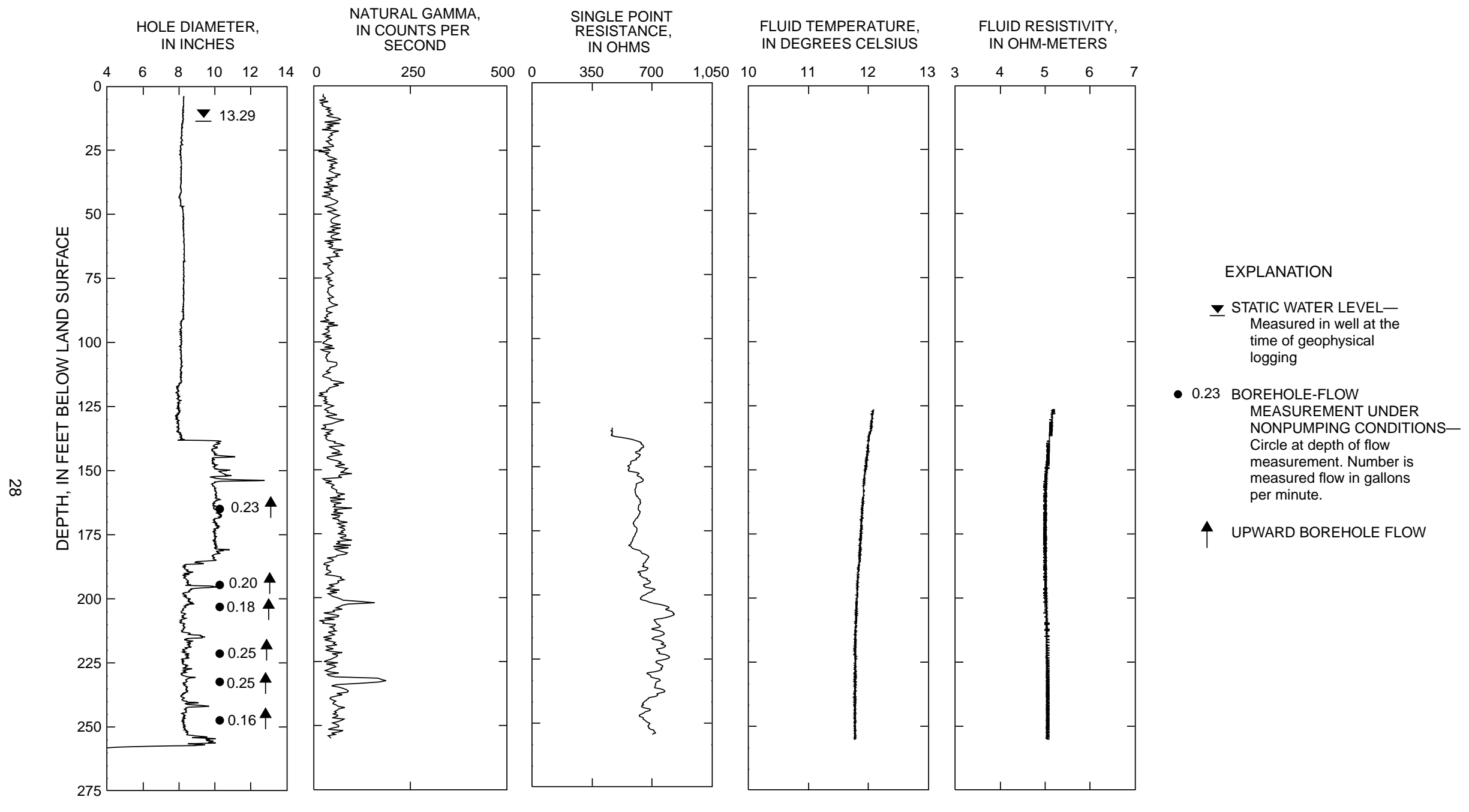

Figure 14. Borehole geophysical logs and direction of nonpumping flow within borehole MG-80 (Lansdale Borough), North Penn Area 6 Superfund Site, Lansdale, Montgomery County, Pennsylvania. 


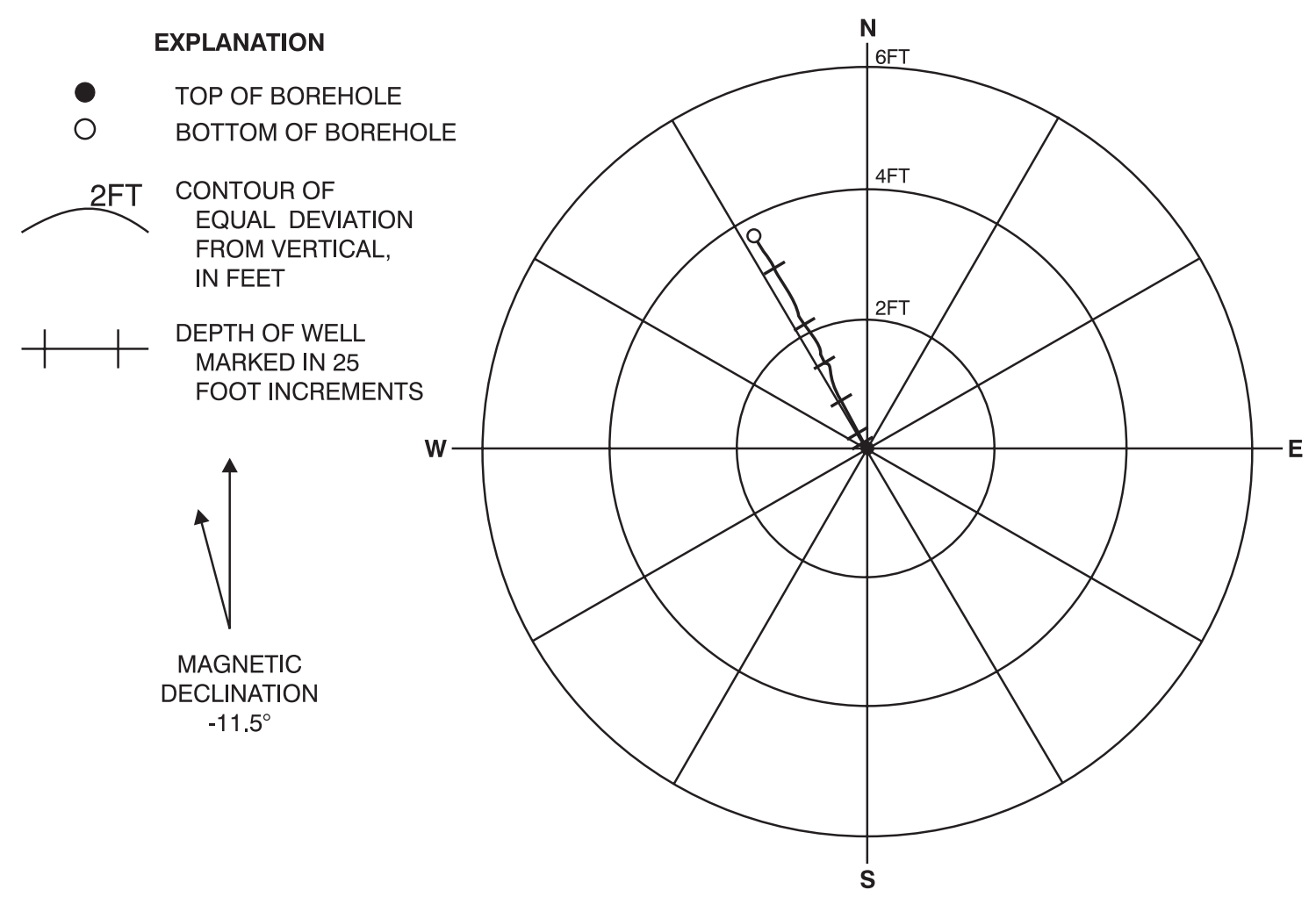

Figure 15. Magnitude and direction of deviation from vertical of borehole MG-80 (Lansdale Borough).

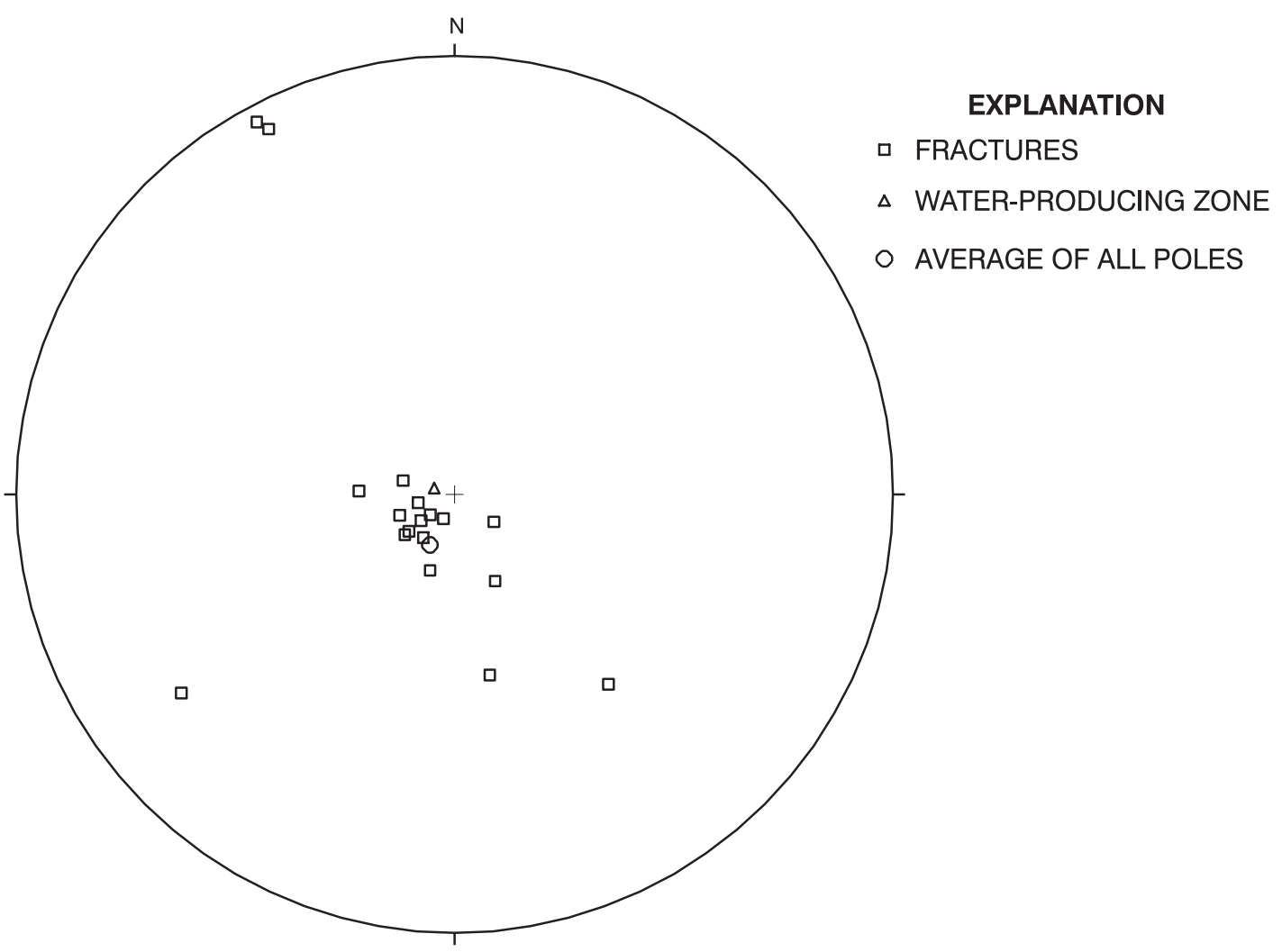

Figure 16. Equal-area lower hemisphere, stereographic projection of poles perpendicular to fracture planes in borehole MG-80 (Lansdale Borough). 


\section{MG-81}

The caliper log shows the total depth of the borehole is $350 \mathrm{ft}$ and it is cased with 6.5-in.-diameter casing to $33 \mathrm{ft}$ bls (fig. 17). The caliper log shows numerous small fractures throughout the open-hole interval plus one major fracture at $336 \mathrm{ft}$ bls. The static water level at the time of logging was $51.70 \mathrm{ft}$ bls. The natural-gamma log shows a thin unit, possibly a shale bed, with elevated gamma readings at 282-284 and $289 \mathrm{ft}$ bls that might be used for stratigraphic correlation of geologic units with other wells. The dipmeter log shows the borehole deviates from vertical approximately $9 \mathrm{ft}$ to the south over the total length of the borehole (fig. 18).

The strike and dip of fracture planes were obtained from the acoustic televiewer. The results are shown on an equal-area stereonet with single points (poles) plotted at right angles to the fracture planes. These poles indicate most fracture planes trend northeast-southwest (fig. 19). The greatest concentration of poles is near the center of figure 19, probably indicating shallow bedding planes. Forty-six possible bedding planes were identified, 35 planes dip to the northwest with an average strike of N. $74^{\circ}$ E., $8^{\circ} \mathrm{NW} . ; 11$ shallow planes dip to the south with an average strike and dip of N. $67^{\circ} \mathrm{W} ., 4^{\circ} \mathrm{SW}$. Twenty fracture planes were identified in the borehole with a strike and dip of N. $62^{\circ}$ E., $37^{\circ} \mathrm{SE}$.

The fluid-temperature logs show slight changes in slope at $146 \mathrm{ft}$ bls and approximately $285 \mathrm{ft}$ bls that correlate to fractures indicated on the caliper log and observed on the video log. Slugs of high conductance fluid were injected at 230 and $310 \mathrm{ft}$ bls and traced with the fluid-resistivity probe; no flow was detected. The suite of borehole geophysical logs and brine-trace data indicate vertical flow within the borehole under nonpumping conditions does not exist or is less than can be detected with these methods.

\section{MG-82 (LB-5)}

This well was logged to a depth of just $92 \mathrm{ft}$ bls because of a pipe in the borehole at about $92 \mathrm{ft}$ bls. The caliper log shows this borehole is cased with 8-in.-diameter casing to $18 \mathrm{ft}$ bls (fig. 20). The caliper log shows major fracture zones at 18-29, 41-51, 59, 64, 66, and 79-83 ft bls plus several smaller fractures. The static water level at the time of logging was $13.96 \mathrm{ft}$ bls. The fluid-temperature log shows changes in slope at 20 and $42 \mathrm{ft}$ bls. Under nonpumping conditions, the heatpulse flowmeter measured slight upward flow at 56 and $70 \mathrm{ft} \mathrm{bls} \mathrm{(table} \mathrm{10).} \mathrm{A} \mathrm{submersible} \mathrm{pump} \mathrm{was} \mathrm{placed} \mathrm{at} 21 \mathrm{ft} \mathrm{bls}$, and the well was pumped at $1 \mathrm{gal} / \mathrm{min}$. The water level in the well declined $1.01 \mathrm{ft}$ after 22 minutes of pumping before stabilizing. The pump discharge rate was incrementally increased to $2 \mathrm{gal} / \mathrm{min}$, then $3 \mathrm{gal} / \mathrm{min}$ while heatpulse flowmetering. While the pumping discharge rate was $3 \mathrm{gal} / \mathrm{min}$, the water level declined at about $0.1 \mathrm{ft} / \mathrm{min}$, indicating most discharge water was derived from the formation and not from borehole storage. The heatpulse flowmeter measured essentially the same direction and flow rates at 56 and $70 \mathrm{ft}$ bls under nonpumping and pumping conditions. The suite of borehole geophysical logs and heatpulse-flowmeter measurements indicate the $1-3 \mathrm{gal} / \mathrm{min}$ of discharge water produced during flowmetering is derived through fractures at $17-29 \mathrm{ft}$ bls.

Table 10. Summary of heatpulse-flowmeter measurements for borehole MG-82 (LB-5) at North Penn Area 6 Superfund Site, Lansdale, Montgomery County, Pennsylvania

[gal/min, gallons per minute]

\begin{tabular}{ccccc}
\hline $\begin{array}{c}\text { Depth } \\
\text { (feet below } \\
\text { land surface) }\end{array}$ & $\begin{array}{c}\text { Flow rate } \\
\text { (gal/min) } \\
\text { nonpumping } \\
\text { conditions }\end{array}$ & $\begin{array}{c}\text { Flow } \\
\text { direction } \\
\text { nonpumping } \\
\text { conditions }\end{array}$ & $\begin{array}{c}\text { Flow rate } \\
\text { (gal/min) } \\
\text { pumping } \\
\text { conditions }\end{array}$ & $\begin{array}{c}\text { Flow } \\
\text { direction } \\
\text { pumping } \\
\text { conditions }\end{array}$ \\
\hline 35 & no flow & not determined & 0.01 & up \\
56 & 0.01 & up & .01 & up \\
70 & .04 & up & .04 & up \\
\hline
\end{tabular}




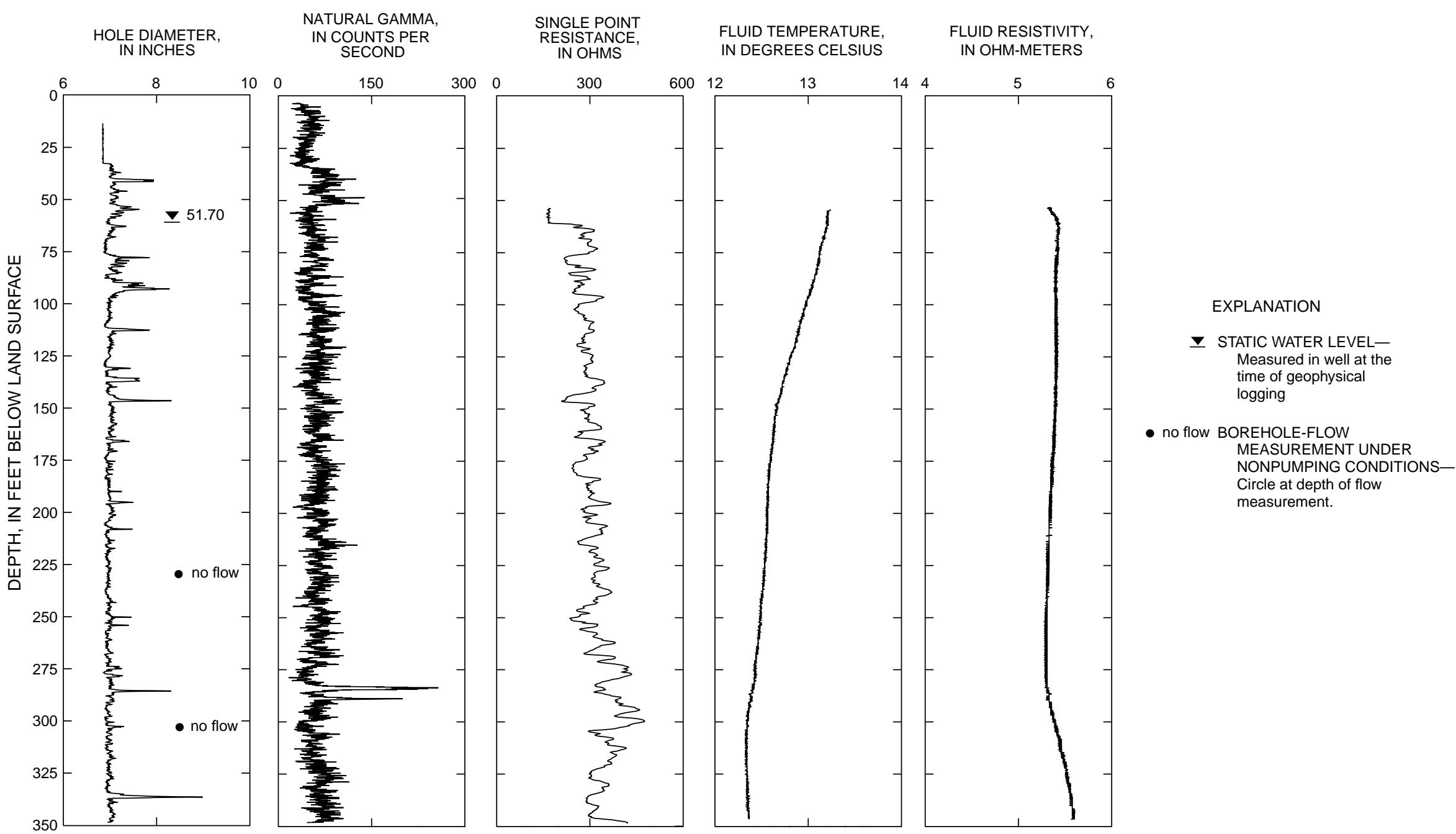

Figure 17. Borehole geophysical logs and direction of nonpumping flow within borehole MG-81, North Penn Area 6 Superfund Site, Lansdale, Montgomery County, Pennsylvania. 


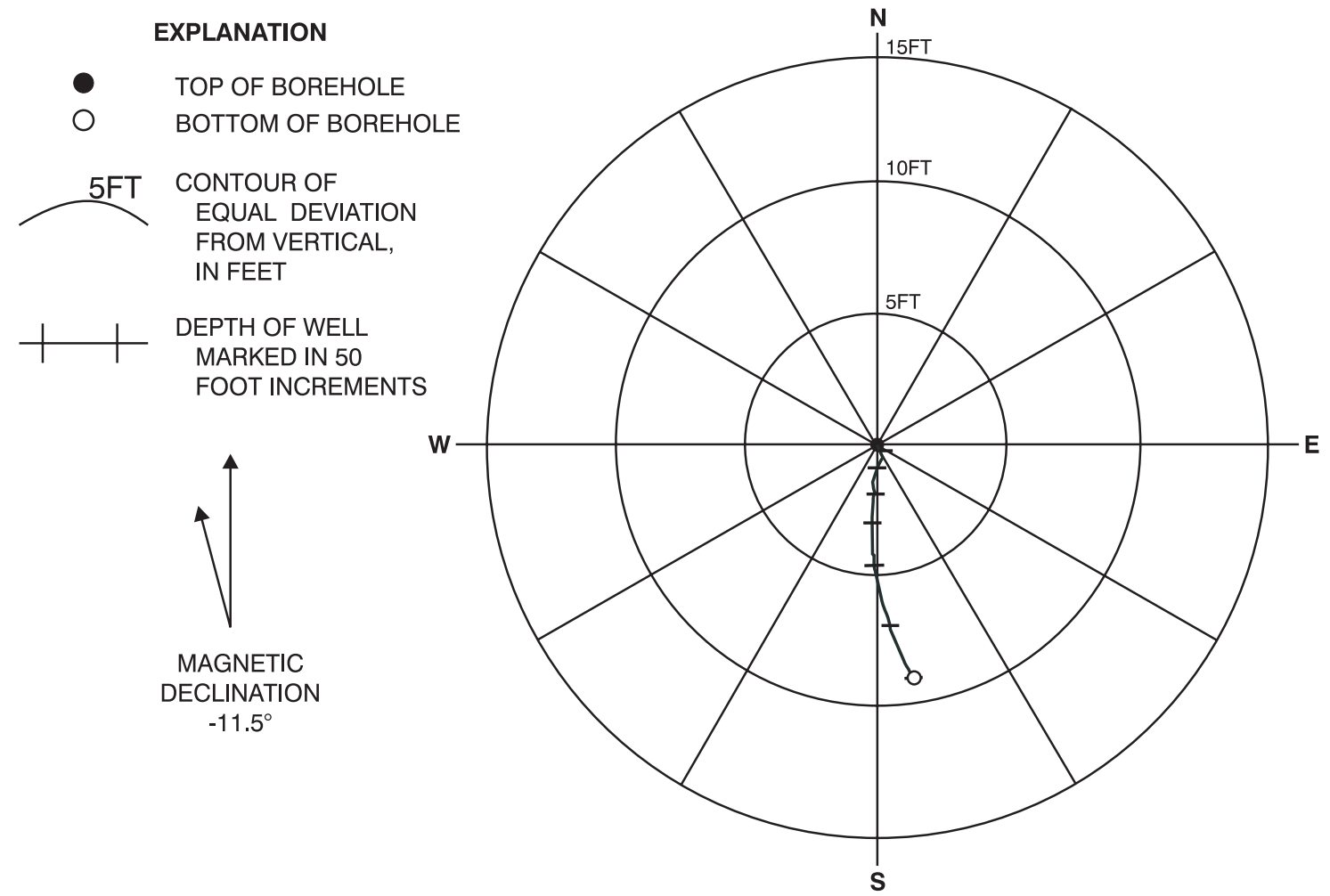

Figure 18. Magnitude and direction of deviation from vertical of borehole MG-81.

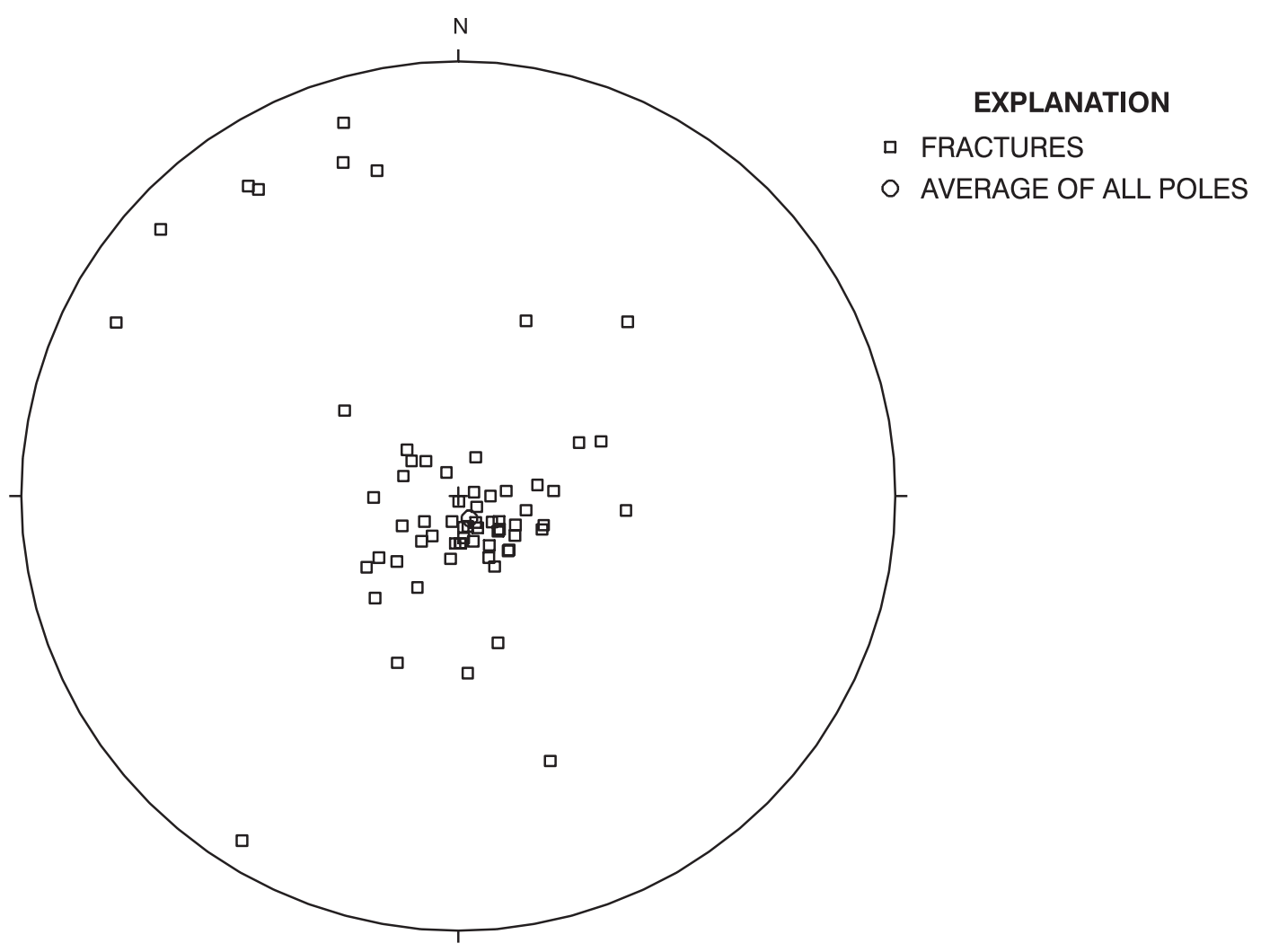

Figure 19. Equal-area lower hemisphere, stereographic projection of poles perpendicular to fracture planes in borehole MG-81. 


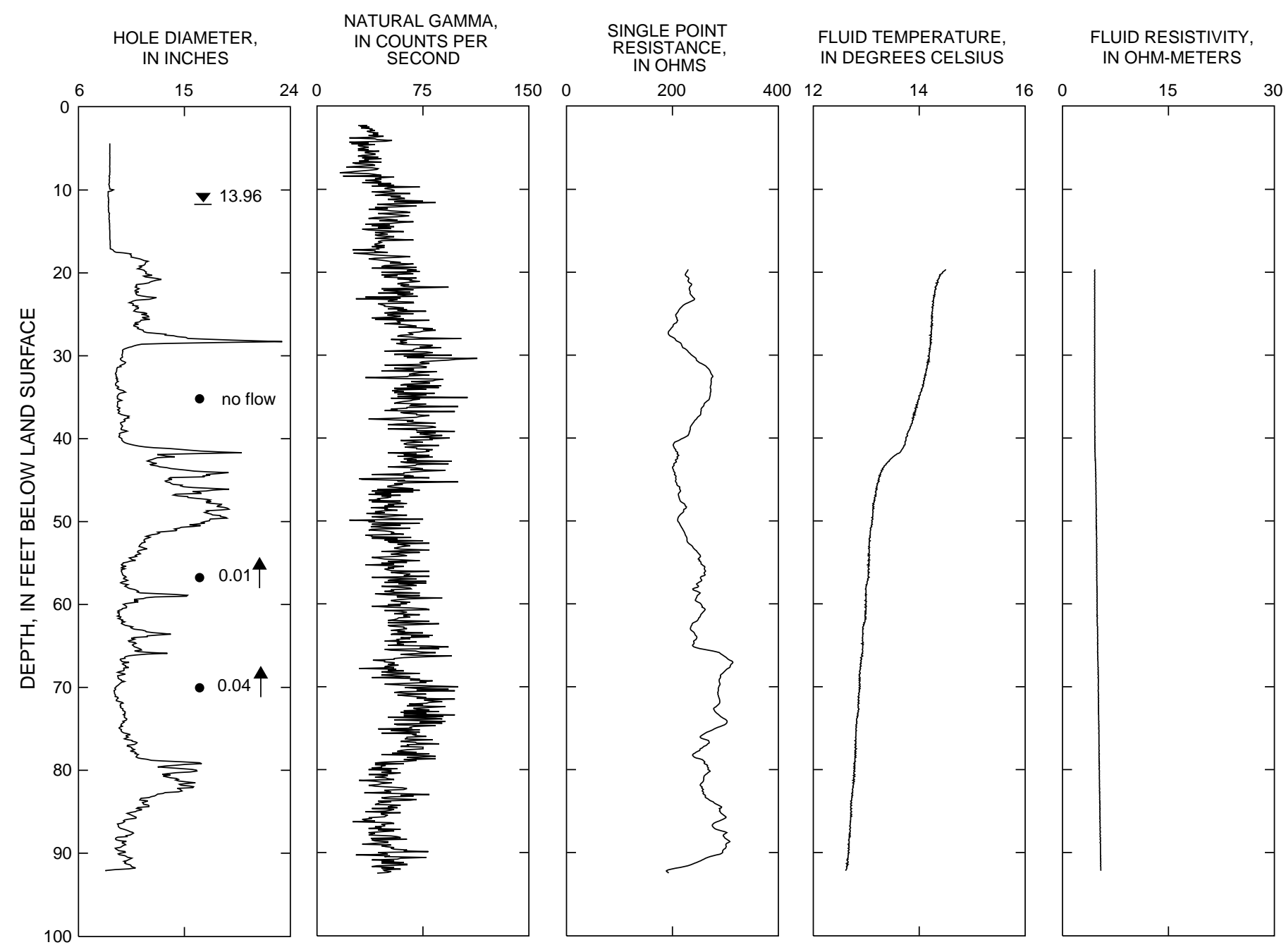

EXPLANATION

- STATIC WATER LEVELMeasured in well at the time of geophysical logging

- 0.01 BOREHOLE-FLOW MEASUREMENT UNDER NONPUMPING CONDITIONSCircle at depth of flow measurement. Number is measured flow in gallons per minute.

† UPWARD BOREHOLE FLOW

Figure 20. Borehole geophysical logs and direction of nonpumping flow within borehole MG-82 (LB-5), North Penn Area 6 Superfund Site, Lansdale, Montgomery County, Pennsylvania. 


\section{MG-138 (Santerians)}

The caliper log shows the total depth of the borehole is $424 \mathrm{ft}$ and it is cased with 10-in.- diameter casing to $22 \mathrm{ft}$ bls (fig. 21). The caliper log shows major fractures at 323-331 and 391-399 ft bls plus numerous other fractures throughout the open-hole interval. The static water level at the time of logging was $39.59 \mathrm{ft}$ bls. The fluid-resistivity and fluid-temperature logs show changes in slope at approximately 50 and $85 \mathrm{ft}$ bls that correlate to fractures on the caliper log. The fluid-temperature log also shows a change in slope at $240 \mathrm{ft}$ bls that correlates to a minor fracture on the caliper log. Under nonpumping conditions, the heatpulse flowmeter measured downward borehole flow at 53, 80, 102, 120, and $150 \mathrm{ft}$ bls and upward flow at 44, 265, 315, 401 and possible but inconclusive upward flow at $348 \mathrm{ft}$ bls (table 11). A submersible pump was placed at $70 \mathrm{ft}$ bls, and the borehole was pumped at approximately $4 \mathrm{gal} / \mathrm{min}$. The water level in the borehole declined $6.99 \mathrm{ft}$ after 49 minutes of pumping before beginning to stabilize. Under pumping conditions, the heatpulse flowmeter measured upward borehole flow at 80, 102, 120, 150, 183, 221, 265, 315, 345,380 , and $402 \mathrm{ft}$ bls. Under nonpumping conditions, water enters the borehole through fractures at 5052,102 , and $120 \mathrm{ft}$ bls, moves downward, and exits the borehole through fractures at 82-86, 130-142, and between 157 to $240 \mathrm{ft}$ bls. Additional water enters the borehole through fractures at $421-423 \mathrm{ft}$ bls, moves upward, and exits the borehole through the fracture at approximately 240 and 391-399 ft bls. Under pumping conditions, the heatpulse-flowmeter measurements indicate the greatest quantity of water enters the borehole through the fractures at 50-52 ft bls; minor amounts of water enter the borehole through fractures at $82-86$ and $421-423 \mathrm{ft}$ bls.

Table 11. Summary of heatpulse-flowmeter measurements for borehole MG-138 (Santerians) at North Penn Area 6 Superfund Site, Lansdale, Montgomery County, Pennsylvania

[gal/min, gallon per minute]

\begin{tabular}{ccccc}
\hline $\begin{array}{c}\text { Depth } \\
\text { feet below } \\
\text { land surface) }\end{array}$ & $\begin{array}{c}\text { Flow rate } \\
\text { (gal/min) } \\
\text { nonpumping } \\
\text { conditions }\end{array}$ & $\begin{array}{c}\text { Flow } \\
\text { direction } \\
\text { nonpumping } \\
\text { conditions }\end{array}$ & $\begin{array}{c}\text { Flow rate } \\
\text { (gal/min) } \\
\text { pumping } \\
\text { conditions }\end{array}$ & $\begin{array}{c}\text { Flow } \\
\text { direction } \\
\text { pumping } \\
\text { conditions }\end{array}$ \\
\hline 44 & 0.08 & up & no data & no data \\
53 & .89 & down & no data & no data \\
80 & 1.20 & down & 0.34 & up \\
102 & .56 & down & .19 & up \\
120 & .90 & down & .19 & up \\
150 & .19 & down & .19 & up \\
183 & no data & no data & .14 & up \\
221 & no data & no data & .18 & up \\
265 & .11 & up & .21 & up \\
315 & .22 & up & .16 & up \\
345 & no data & no data & .23 & no data \\
348 & possible flow & possibly up & no data & up \\
380 & no data & no data & .18 & no data \\
401 & .19 & up & no data & up \\
402 & no data & no data & .23 & \\
\hline
\end{tabular}




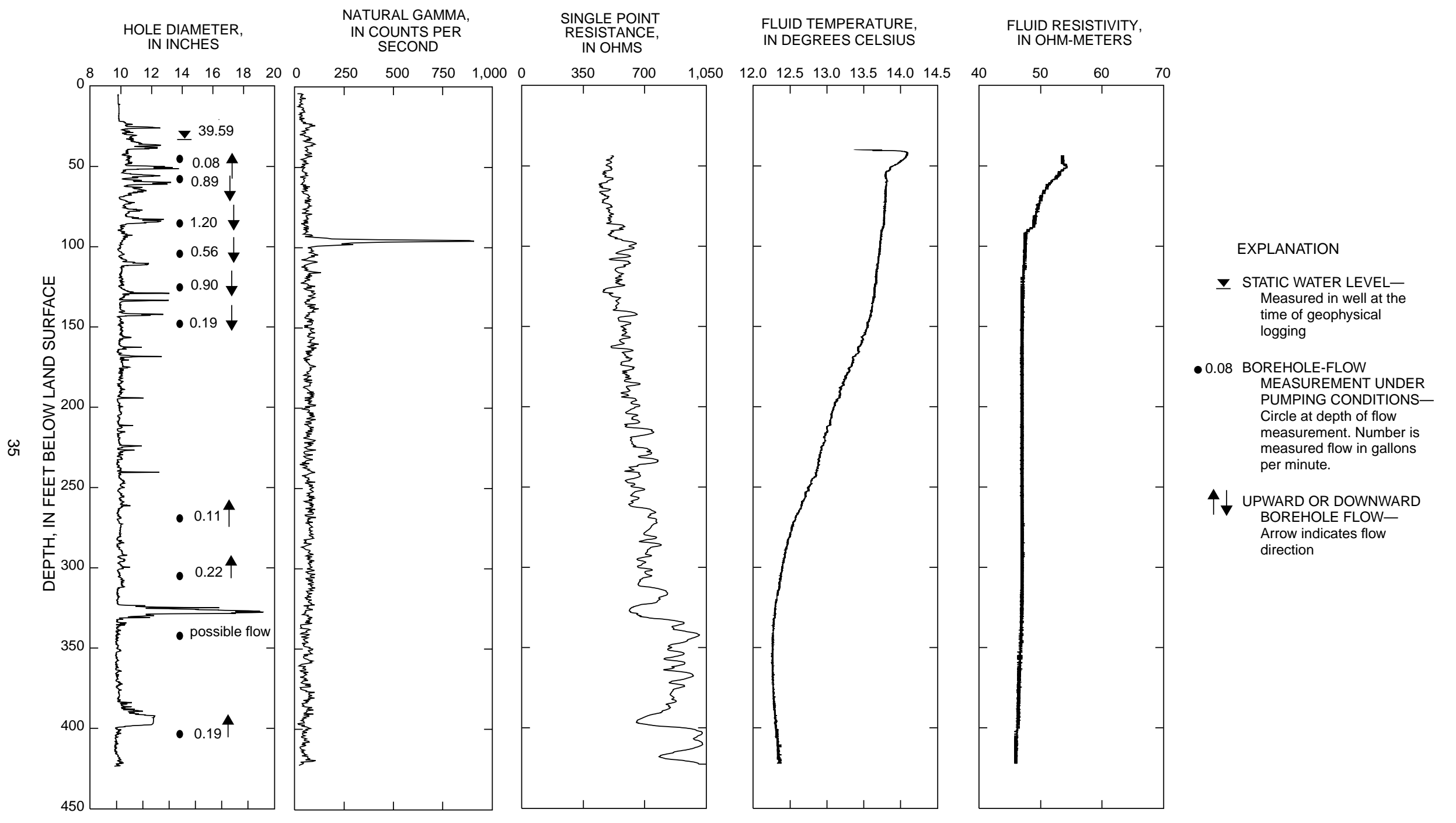

Figure 21. Borehole-geophysical logs and direction of nonpumping flow within borehole MG-138 (Santerians), North Penn Area 6 Superfund Site, Lansdale, Montgomery County, Pennsylvania. 


\section{MG-143 (L-21)}

The caliper $\log$ shows the total depth of the borehole is $392 \mathrm{ft}$ and it is cased with 12-in.-diameter casing to $30 \mathrm{ft}$ bls (fig. 22). The caliper log shows major fracture zones at 30-53 and 330-340 ft bls plus numerous smaller fractures throughout the open-hole interval. The static water level in the well at the time of logging was $10.08 \mathrm{ft}$ bls. The natural-gamma log shows a thin unit, possibly a shale bed, with elevated gamma readings at 235 and 359-363 ft bls that might be used for stratigraphic correlation of geologic units with other wells. The fluid-temperature and fluid-resistivity logs show slight changes in slope at $82 \mathrm{and} 340 \mathrm{ft}$ bls that correlate to fractures on the caliper log and the video log. The heatpulse flowmeter is not designed to be used in a well diameter greater than 8 in. Therefore, heatpulse flowmetering under nonpumping or pumping conditions was not conducted. A slug of high-conductance fluid was injected at 130, 215, 290, and $350 \mathrm{ft}$ bls; no detectable borehole flow was measured. The suite of borehole geophysical logs and brine-trace data indicate nonpumping vertical borehole flow does not exist or is too small to measure.

\section{MG-152 (American Olean Tile production well \#1)}

The caliper log shows the total depth of the borehole is $196 \mathrm{ft}$ and it is cased with 10-in.-diameter casing to $22 \mathrm{ft}$ bls (fig. 23). The caliper log shows major fractures at 20-32, 114-117,163-167, and $177 \mathrm{ft}$ bls plus numerous other fractures throughout the open-hole interval. The static water level in the well at the time of logging was $49.41 \mathrm{ft}$ bls. The fluid-resistivity and fluid-temperature logs show changes in slope at approximately 53, 68, and $169 \mathrm{ft}$ bls that are generally indicative of water-producing and water-receiving zones. Under nonpumping conditions, the heatpulse flowmeter measured upward borehole flow at 55, 105, $123,156,172$, and $186 \mathrm{ft}$ bls (table 12). A submersible pump was placed at $60 \mathrm{ft}$ bls, and the borehole was pumped at approximately $4 \mathrm{gal} / \mathrm{min}$. The water level in the borehole declined $1.03 \mathrm{ft}$ in 21 minutes, then stabilized and remained so during the 1 hour and 22 minutes of pumping. Under pumping conditions, the heatpulse flowmeter measured upward borehole flow at 76, 105, 123, 156, 172, and $186 \mathrm{ft}$ bls. The suite of borehole geophysical logs and the heatpulse-flowmeter measurements suggest the greatest quantity of water is produced from fractures at 63-68 ft bls under nonpumping and from fractures at 114-117 ft bls under pumping conditions. Minor amounts of water are produced from fractures below $186 \mathrm{ft}$ bls under nonpumping and pumping conditions. Additionally, fractures near 163-167 ft bls and 114-117 ft bls produce minor amounts of water under pumping conditions.

Table 12. Summary of heatpulse-flowmeter measurements for borehole MG-152 (American Olean Tile production well \#1) at North Penn Area 6 Superfund Site, Lansdale, Montgomery County, Pennsylvania

[gal/min, gallon per minute]

\begin{tabular}{ccccc}
\hline $\begin{array}{c}\text { Depth } \\
\text { feet below } \\
\text { land surface) }\end{array}$ & $\begin{array}{c}\text { Flow rate } \\
\text { (gal/min) } \\
\text { nonpumping } \\
\text { conditions }\end{array}$ & $\begin{array}{c}\text { Flow direction } \\
\text { nonpumping } \\
\text { conditions }\end{array}$ & $\begin{array}{c}\text { Flow rate } \\
\text { (gal/min) } \\
\text { pumping } \\
\text { conditions }\end{array}$ & $\begin{array}{c}\text { Flow direction } \\
\text { pumping } \\
\text { conditions }\end{array}$ \\
\hline 55 & 0.25 & up & no data & no data \\
76 & no data & no data & 0.35 & up \\
105 & .08 & up & .32 & up \\
123 & .09 & up & .14 & up \\
156 & .07 & up & .14 & up \\
172 & .07 & up & .08 & up \\
186 & .09 & up & .08 & up \\
\hline
\end{tabular}




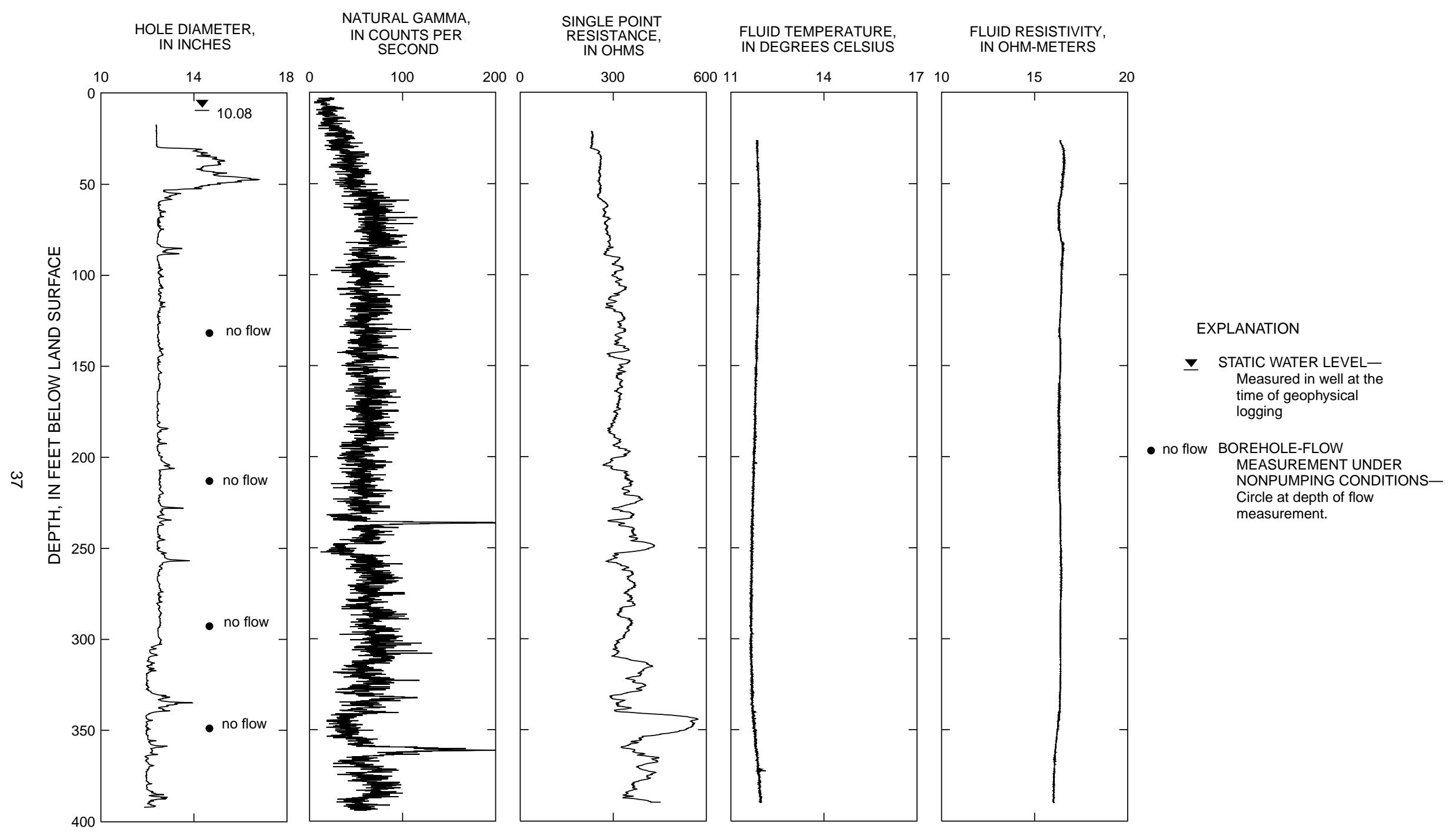

Figure 22. Borehole geophysical logs and direction of nonpumping flow within borehole MG-143 (L-21), North Penn Area 6 Superfund Site, Lansdale, Montgomery County, Pennsylvania. 

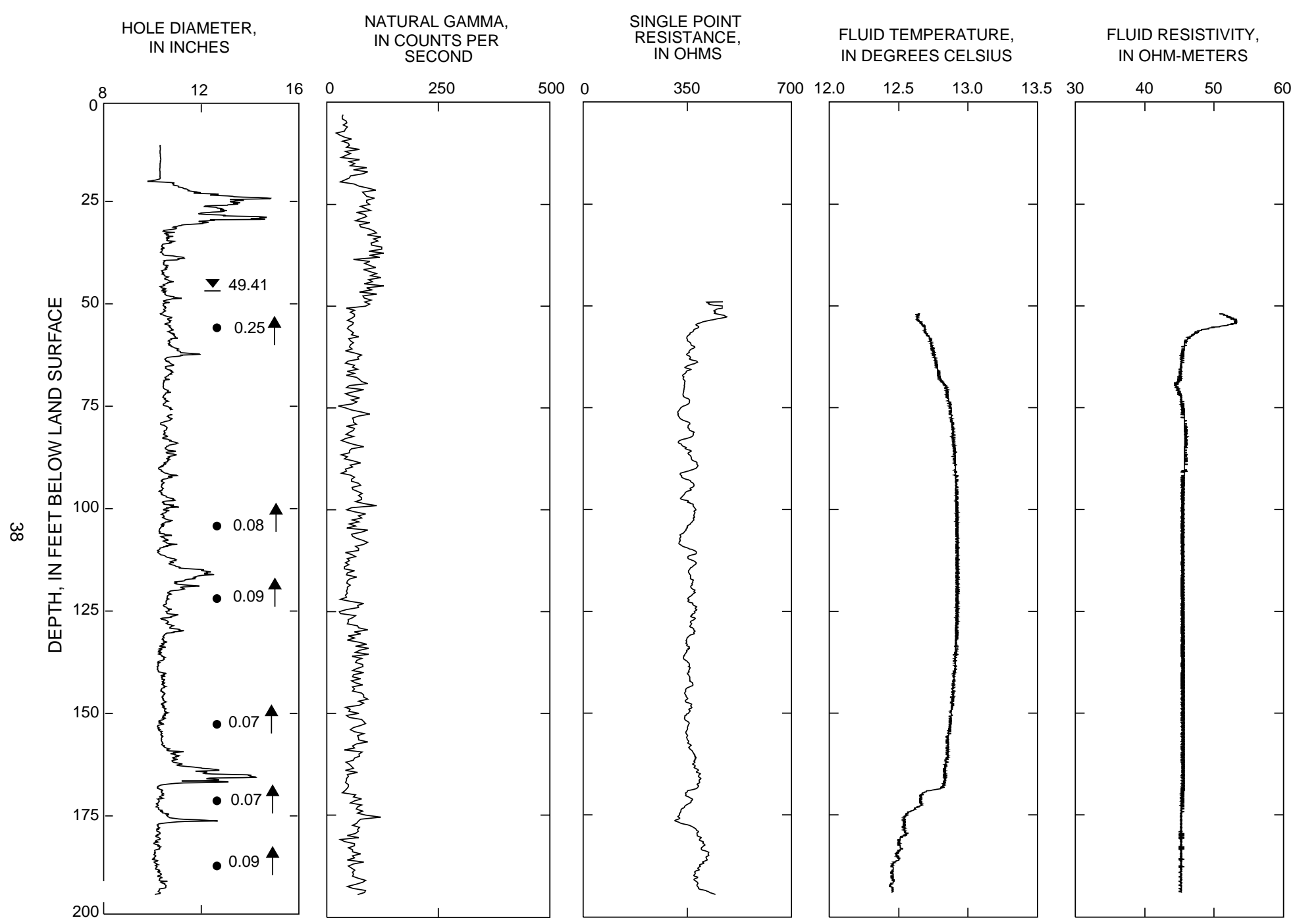

EXPLANATION

- STATIC WATER LEVELMeasured in well at the time of geophysical logging

- 0.25 BOREHOLE-FLOW MEASUREMENT UNDER NONPUMPING

Circle at depth of flow

measurement. Number is measured flow in gallons

$\hat{1}$ per minute.

Figure 23. Borehole-geophysical logs and direction of nonpumping flow within borehole MG-152 (American Olean Tile production well \#1), North Penn Area 6 Superfund Site, Lansdale, Montgomery County, Pennsylvania. 


\section{MG-154 (E nviroTech)}

The caliper log shows the total depth of the borehole is $183 \mathrm{ft}$ and it is cased with 6-in.-diameter casing to $35 \mathrm{ft}$ bls (fig. 24). The caliper log shows major fractures at 35.5-57, 69, 118-130, and $135 \mathrm{ft}$ bls plus numerous other fractures throughout the open-hole interval. The static water level in the well at the time of logging was $51.16 \mathrm{ft}$ bls. The fluid-resistivity log shows changes in slope at approximately $54-84 \mathrm{ft}$ bls that are generally indicative of water-producing or water-receiving zones. Under nonpumping conditions, the heatpulse flowmeter measured upward borehole flow at 85, 90, 110, and $140 \mathrm{ft}$ bls. (table 13). The suite of borehole geophysical logs and the heatpulse-flowmeter measurements show water enters the borehole through fractures at 140-142 ft bls, moves upward, and exits the borehole through fractures at 63-88 ft bls.

Table 13. Summary of heatpulse-flowmeter measurements for borehole MG-154 (EnviroTech) at North Penn Area 6 Superfund Site, Lansdale, Montgomery County, Pennsylvania

[gal/min, gallon per minute]

\begin{tabular}{ccc}
$\begin{array}{c}\text { Depth } \\
\text { (feet below } \\
\text { land surface) }\end{array}$ & $\begin{array}{c}\text { Flow rate } \\
\text { (gal/min) } \\
\text { nonpumping } \\
\text { conditions }\end{array}$ & $\begin{array}{c}\text { Flow direction } \\
\text { nonpumping } \\
\text { conditions }\end{array}$ \\
\hline 60 & no flow & not determined \\
85 & 0.11 & up \\
90 & .16 & up \\
110 & .10 & up \\
140 & .18 & up \\
145 & no flow & not determined \\
160 & no flow & not determined \\
170 & no flow & not determined \\
\hline
\end{tabular}




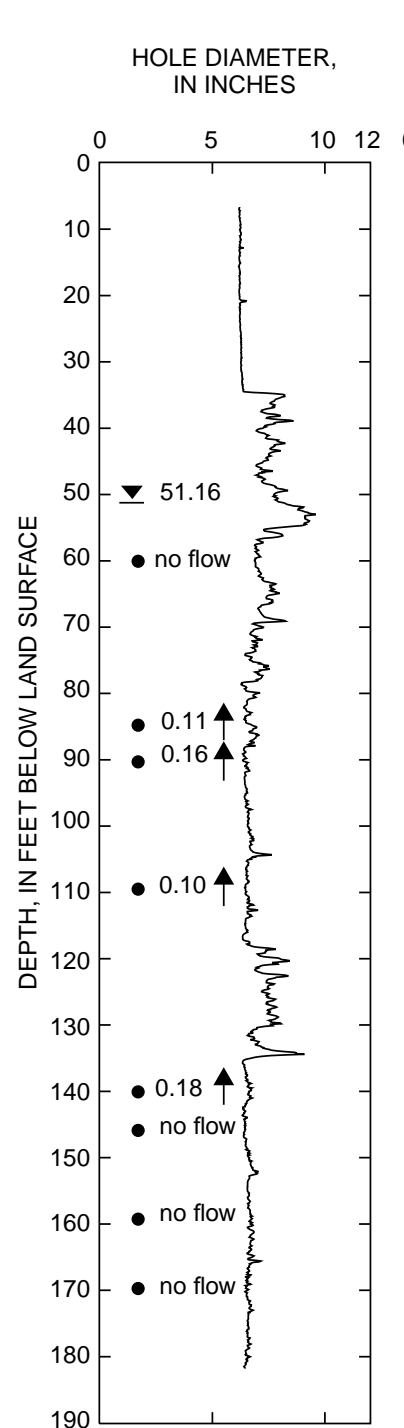

$$
\begin{aligned}
& \text { NATURAL GAMMA, } \\
& \text { IN COUNTS PER } \\
& \text { SECOND }
\end{aligned}
$$

SINGLE-POINT RESISTANCE,

IN OHMS

FLUID TEMPERATURE, IN DEGREES CELSIUS

FLUID RESISTIVITY,
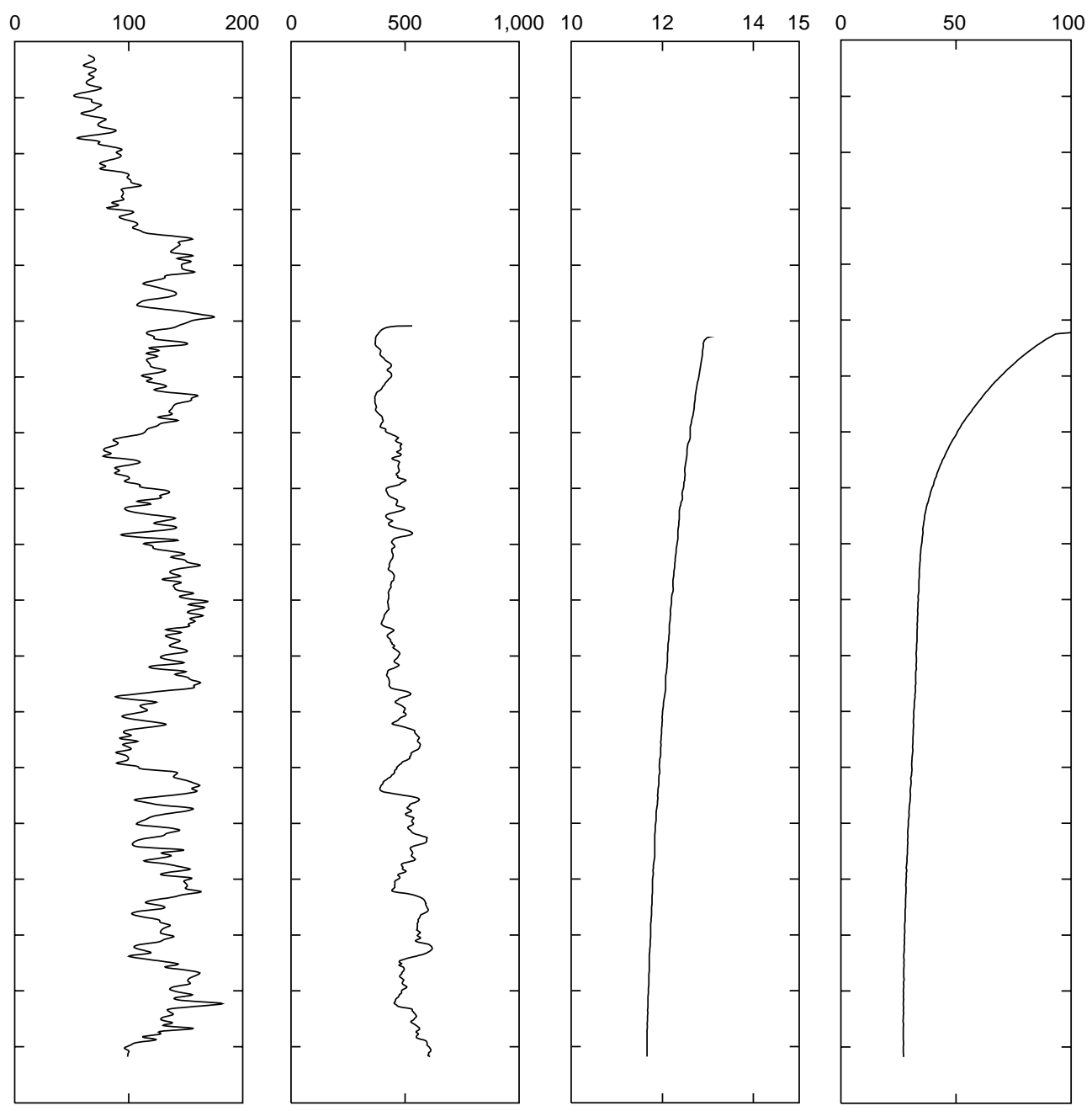

EXPLANATION

- STATIC WATER LEVELMeasured in well at the
time of geophysical logging

- 0.11 BOREHOLE-FLOW

MEASUREMENT UNDER NONPUMPING CONDITIONS-

Circle at depth of flow

measurement. Number is

measured flow in gallons

per minute.

个 UPWARD BOREHOLE FLOW

Figure 24. Borehole geophysical logs and direction of nonpumping flow within borehole MG-154 (EnviroTech), North Penn Area 6 Superfund Site, Lansdale, Montgomery County, Pennsylvania. 


\section{MG-157 (F airhills Fabricating)}

The caliper log shows the total depth of the borehole is $268 \mathrm{ft}$ and it is cased with 8-in. diameter casing to $45 \mathrm{ft}$ bls (fig. 25). The caliper log shows major fracture zones at 64-66, 67-68, 92-94, 96-97, 124-127, and $187 \mathrm{ft}$ bls plus numerous smaller fractures throughout the open-hole interval. The static water level in the well at the time of logging was $6.57 \mathrm{ft}$ bls. The natural-gamma log shows shale units with elevated gamma readings at 181-184 ft bls that might be used for stratigraphic correlation of geologic units with other wells. Under nonpumping conditions, the heatpulse flowmeter measured upward flow at 52, 76, 108, 132, 170, 192,215 , and $240 \mathrm{ft}$ bls (table 14). A submersible pump was placed at $30 \mathrm{ft}$ bls, and the well was pumped less than $1 \mathrm{gal} / \mathrm{min}$. The water level in the well declined $3.08 \mathrm{ft}$ during 1 hour and 47 minutes while pumping at different discharge rates. Heatpulse-flowmeter measurements were again made at the same depths as before pumping. The suite of borehole geophysical logs and heatpulse-flowmeter measurements indicate during pumping, the greatest quantity of water enters the borehole through fractures near 124$127 \mathrm{ft}$ bls. Additionally, water is produced through the fractures at 187 and below $240 \mathrm{ft}$ bls.

Table 14. Summary of heatpulse-flowmeter measurements for borehole MG-157 (Fairhills Fabricating) at North Penn Area 6 Superfund Site, Lansdale, Montgomery County, Pennsylvania

[gal/min, gallon per minute]

\begin{tabular}{ccccc}
\hline $\begin{array}{c}\text { Depth } \\
\text { (feet below } \\
\text { land surface) }\end{array}$ & $\begin{array}{c}\text { Flow rate } \\
\text { (gal/min) } \\
\text { nonpumping } \\
\text { conditions }\end{array}$ & $\begin{array}{c}\text { Flow direction } \\
\text { nonpumping } \\
\text { conditions }\end{array}$ & $\begin{array}{c}\text { Flow rate } \\
\text { (gal/min) } \\
\text { pumping } \\
\text { conditions }\end{array}$ & $\begin{array}{c}\text { Flow direction } \\
\text { pumping } \\
\text { conditions }\end{array}$ \\
\hline 52 & 0.15 & up & 0.95 & up \\
76 & .20 & up & .97 & up \\
108 & .30 & up & .90 & up \\
132 & .20 & up & .47 & up \\
170 & .23 & up & .36 & up \\
192 & .18 & up & .16 & up \\
215 & .13 & up & .13 & up \\
240 & .12 & up & .14 & up \\
\hline
\end{tabular}




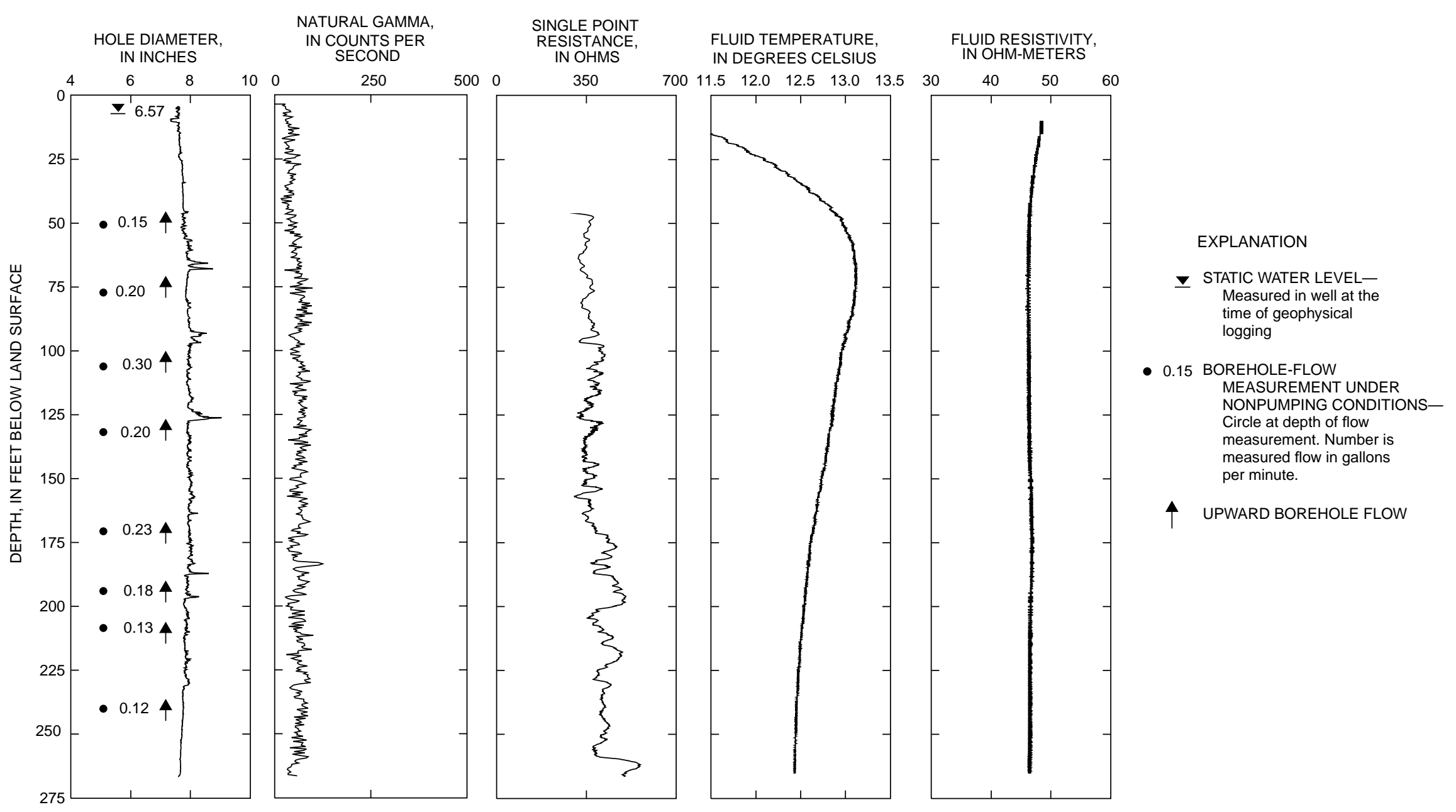

Figure 25. Borehole geophysical logs and direction of nonpumping flow within borehole MG-157 (Fairhills Fabricating), North Penn Area 6 Superfund Site, Lansdale, Montgomery County, Pennsylvania. 


\section{MG-163 (Rybond \#3)}

The caliper $\log$ shows the total depth of the borehole is $318 \mathrm{ft}$ and it is cased with 8-in.-diameter casing to $22 \mathrm{ft}$ bls (fig. 26). The caliper log shows major fracture zones at 48, 50, 81, 104-112, 134-139, 172-174, 224, 239,252 , and 276-279 ft bls plus numerous smaller fractures throughout the open-hole interval. The static water level in the well at the time of logging was $25.43 \mathrm{ft}$ bls. The natural-gamma log shows shale units with elevated gamma readings at 251-255 and 289-294 ft bls that might be used for stratigraphic correlation of geologic units with other wells. The fluid-temperature log shows general changes in slope at 42, 70, and $140 \mathrm{ft}$ bls. Under nonpumping conditions, the heatpulse flowmeter measured upward flow at 37, 62, 96, 168, $192,216,232,246,264,282$, and $300 \mathrm{ft}$ bls (table 15). A submersible pump was placed at $50 \mathrm{ft}$ bls, and the well was pumped at about $1 \mathrm{gal} / \mathrm{min}$. The water level in the well stabilized quickly at $25.55 \mathrm{ft}$ bls. The suite of borehole geophysical logs and heatpulse-flowmeter measurements indicate during pumping, the greatest quantity of water enters the borehole through fractures near 104-111 ft bls. Approximately twothirds of the discharge water produced below $111 \mathrm{ft}$ is from the fracture at $134-139 \mathrm{ft}$ bls.

Table 15. Summary of heatpulse-flowmeter measurements for borehole MG-163 (Rybond \#3) at North Penn Area 6 Superfund Site, Lansdale, Montgomery County, Pennsylvania

[gal/min, gallon per minute]

\begin{tabular}{ccccc}
\hline $\begin{array}{c}\text { Depth } \\
\text { (feet below } \\
\text { land surface) }\end{array}$ & $\begin{array}{c}\text { Flow rate } \\
\text { (gal/min) } \\
\text { nonpumping } \\
\text { conditions }\end{array}$ & $\begin{array}{c}\text { Flow direction } \\
\text { nonpumping } \\
\text { conditions }\end{array}$ & $\begin{array}{c}\text { Flow rate } \\
\text { (gal/min) } \\
\text { pumping } \\
\text { conditions }\end{array}$ & $\begin{array}{c}\text { Flow direction } \\
\text { pumping } \\
\text { conditions }\end{array}$ \\
\hline 37 & 0.12 & up & no data & no data \\
62 & .11 & up & 1.1 & up \\
86 & no data & no data & 1.0 & up \\
96 & .08 & up & .98 & up \\
118 & no data & no data & .26 & up \\
168 & .13 & up & .1 & up \\
192 & .14 & up & no data & no data \\
216 & .15 & up & no data & no data \\
232 & .28 & up & no data & no data \\
246 & .25 & up & no data & no data \\
264 & .26 & up & no data & no data \\
282 & .30 & up & no data & no data \\
300 & .20 & up & no data &
\end{tabular}




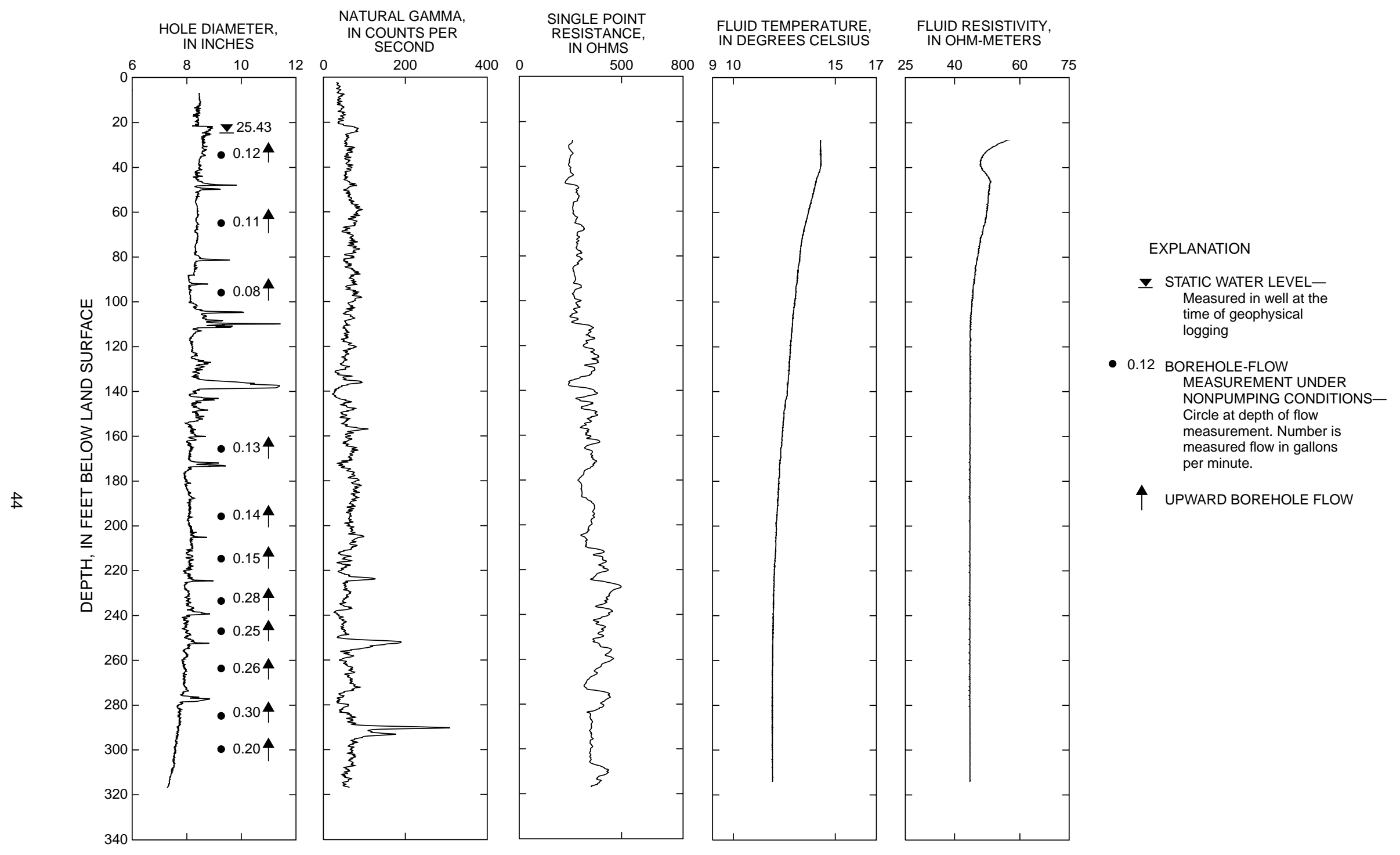

Figure 26. Borehole geophysical logs and direction of nonpumping flow within borehole MG-163 (Ryband \#3), North Penn Area 6 Superfund Site, Lansdale, Montgomery County, Pennsylvania. 


\section{MG-164 (Rybond \#4)}

The caliper log shows the total depth of the borehole is $385 \mathrm{ft}$ and it is cased with 8-in.-diameter casing to $23 \mathrm{ft}$ bls (fig. 27). The caliper log shows major fracture zones at 23-24, 39-41, 62-65, 99-101, 105, 108, 270274, 352, and 354-357 ft bls plus numerous smaller fractures throughout the open-hole interval. The caliper $\log$ shows the borehole diameter is $8 \mathrm{in}$. from 23 to $305 \mathrm{ft}$ bls and $6 \mathrm{in}$. from 306 to $385 \mathrm{ft}$ bls. The static water level in the well at the time of logging was $27.53 \mathrm{ft}$ bls. The natural-gamma log shows shale units with elevated gamma readings at 158-160, 189-191, and 224-226 ft bls that might be used for stratigraphic correlation of geologic units with other wells. The fluid-temperature log shows changes in slope at 62, 98113 , and $306 \mathrm{ft}$ bls that correlate to fractures shown on the caliper log. Under nonpumping conditions, the heatpulse flowmeter measured downward flow at 92, 124, 148, 172, 206, 236, 260, 292, 332, and $362 \mathrm{ft}$ bls (table 16). A submersible pump was placed at $50 \mathrm{ft}$ bls, and the well was pumped at a rate slightly less than $2 \mathrm{gal} / \mathrm{min}$. The water level in the well stabilized after 43 minutes of pumping at $29.31 \mathrm{ft}$ bls. Because the water level was not stabilized during most of the pumping, part of the discharge was derived from borehole storage and part from the aquifer, resulting in a flow measurement less than the actual flow rate. The suite of borehole geophysical logs and heatpulse-flowmeter measurements indicate water enters the borehole through fractures at $62-65,99-113,154$, and $245-257 \mathrm{ft}$ bls. Water exits the borehole through fractures at 222, 270-274, 300-358, and below $362 \mathrm{ft}$ bls. During pumping, the greatest quantity of water enters the borehole through fractures near 62-65 and 99-113 ft bls.

Table 16. Summary of heatpulse-flowmeter measurements for borehole MG-164 (Rybond \#4) at North Penn Area 6 Superfund Site, Lansdale, Montgomery County, Pennsylvania

[gal/min, gallon per minute]

\begin{tabular}{ccccc}
\hline $\begin{array}{c}\text { Depth } \\
\text { (feet below } \\
\text { land surface) }\end{array}$ & $\begin{array}{c}\text { Flow rate } \\
\text { (gal/min) } \\
\text { nonpumping } \\
\text { conditions }\end{array}$ & $\begin{array}{c}\text { Flow direction } \\
\text { nonpumping } \\
\text { conditions }\end{array}$ & $\begin{array}{c}\text { Flow rate } \\
\text { (gal/min) } \\
\text { pumping } \\
\text { conditions }\end{array}$ & $\begin{array}{c}\text { Flow direction } \\
\text { pumping } \\
\text { conditions }\end{array}$ \\
\hline 92 & 0.29 & down & 1.2 & up \\
124 & .92 & down & .47 & up \\
148 & .98 & down & .07 & up \\
172 & 1.2 & down & .99 & down \\
206 & 1.1 & down & .69 & down \\
236 & .44 & down & .21 & down \\
260 & .85 & down & .75 & not determined \\
292 & .62 & down & no data & not determined \\
332 & .43 & down & no data & not determined \\
362 & .41 & down & no data &
\end{tabular}




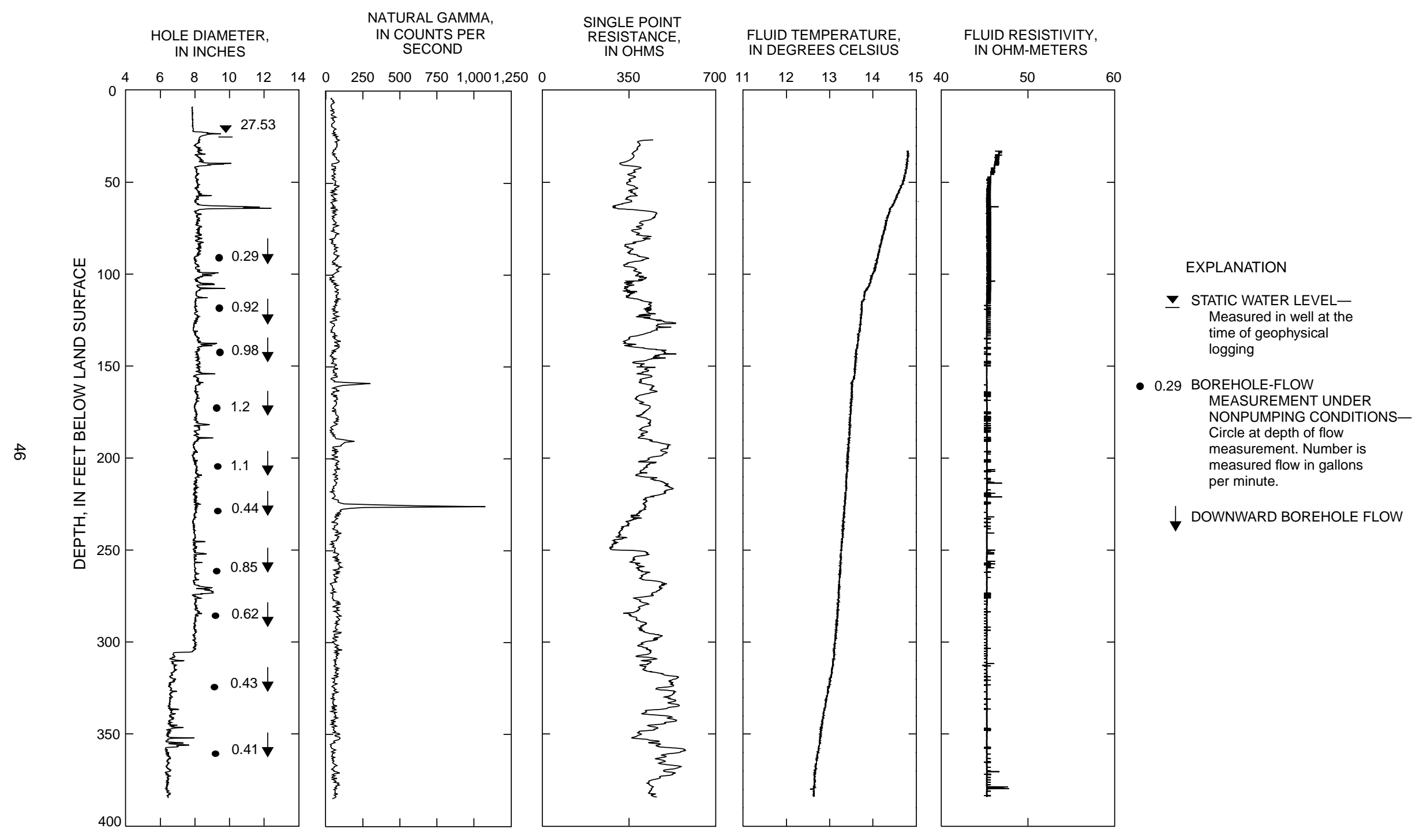

Figure 27. Borehole geophysical logs and direction of nonpumping flow within borehole MG-164 (Rybond \#4), North Penn Area 6 Superfund Site, Lansdale, Montgomery County, Pennsylvania. 


\section{MG-498 (L-23)}

The caliper $\log$ shows the total depth of the borehole is $587 \mathrm{ft}$ and it is cased with 12-in.-diameter casing to $97 \mathrm{ft}$ bls (fig. 28). The caliper log shows major fracture zones at 116-122, 157-164, 167-169, 220-227, 244246, 249-251, 254-257, 390-393, 403-405, and 435-442 ft bls plus numerous smaller fractures throughout the open-hole interval. The caliper log shows the borehole diameter is $12 \mathrm{in}$. from 97 to $413 \mathrm{ft}$ bls and $10 \mathrm{in}$. from 413 to $587 \mathrm{ft}$ bls. The static water level in the well at the time of logging was $46.16 \mathrm{ft}$ bls. The natural-gamma log shows shale units with elevated gamma readings at 202-204, 294-296, and 321-326 ft bls that might be used for stratigraphic correlation of geologic units with other wells. The fluid-resistivity logs show changes in slope at 110 and $152 \mathrm{ft}$ bls that correlate to fracture zones shown on the caliper log. The fluid-temperature $\log$ shows a change in slope at approximately $440 \mathrm{ft}$ bls that correlates to fractures shown on the caliper log. Because the borehole diameter exceeds the 8 -in. maximum recommended by the heatpulse-flowmeter manufacturer, all flow measurements should be considered relative estimates. Under nonpumping conditions, the heatpulse flowmeter measured upward flow at 450,480,526, and $554 \mathrm{ft}$ bls and no flow at 104, 136, 190, 240, 290, 340, 386, and $424 \mathrm{ft}$ bls (table 17). A submersible pump was placed at $60 \mathrm{ft}$ bls, and the well was pumped at approximately $4 \mathrm{gal} / \mathrm{min}$. After 1 hour and 10 minutes of pumping, the water level declined $4.86 \mathrm{ft}$ but never completely stabilized, which indicates part of the discharge was derived from borehole storage and part from the aquifer, resulting in a flow measurement less than the actual rate. A check measurement of flow within the casing while pumping the well indicated that only $0.19 \mathrm{gal} / \mathrm{min}$ of the $4 \mathrm{gal} / \mathrm{min}$ of pumping could be measured by the heatpulse flowmeter. This is mostly the result of flow bypassing the flowmeter because of the large casing diameter. Under nonpumping conditions, the suite of borehole geophysical logs and heatpulse-flowmeter measurements indicate water enters the borehole through fractures at 566-576 ft bls, moves upward, and exits the borehole through fractures at 435-442 ft bls. Under pumping conditions, the greatest quantity of water enters the borehole through fractures at 157$169 \mathrm{ft}$ bls.

Table 17. Summary of heatpulse-flowmeter measurements for borehole MG-498 (L-23) at North Penn Area 6 Superfund Site, Lansdale, Montgomery County, Pennsylvania

[gal/min, gallon per minute]

\begin{tabular}{ccccc}
\hline $\begin{array}{c}\text { Depth } \\
\text { (feet below } \\
\text { land surface) }\end{array}$ & $\begin{array}{c}\text { Flow rate } \\
\text { (gal/min) } \\
\text { nonpumping } \\
\text { conditions }\end{array}$ & $\begin{array}{c}\text { Flow direction } \\
\text { nonpumping } \\
\text { conditions }\end{array}$ & $\begin{array}{c}\text { Flow rate } \\
\text { (gal/min) } \\
\text { pumping } \\
\text { conditions }\end{array}$ & $\begin{array}{c}\text { Flow direction } \\
\text { pumping } \\
\text { conditions }\end{array}$ \\
\hline 90 & no data & no data & 10.19 & up \\
104 & no flow & not determined & .17 & up \\
136 & no flow & not determined & .12 & up \\
190 & no flow & not determined & up \\
240 & no flow & not determined & no flow & no data \\
290 & no flow & not determined & no data & no data \\
340 & no flow & not determined & no data & no data \\
386 & no flow & not determined & no data & no data \\
424 & no flow & not determined & no data & no data \\
450 & 0.09 & up & no data & no data \\
480 & .09 & up & no data & no data \\
526 & .08 & up & no data & no data \\
554 & .09 & up & no data & no data \\
\hline
\end{tabular}

${ }^{1}$ Measured inside casing as calibration check. 


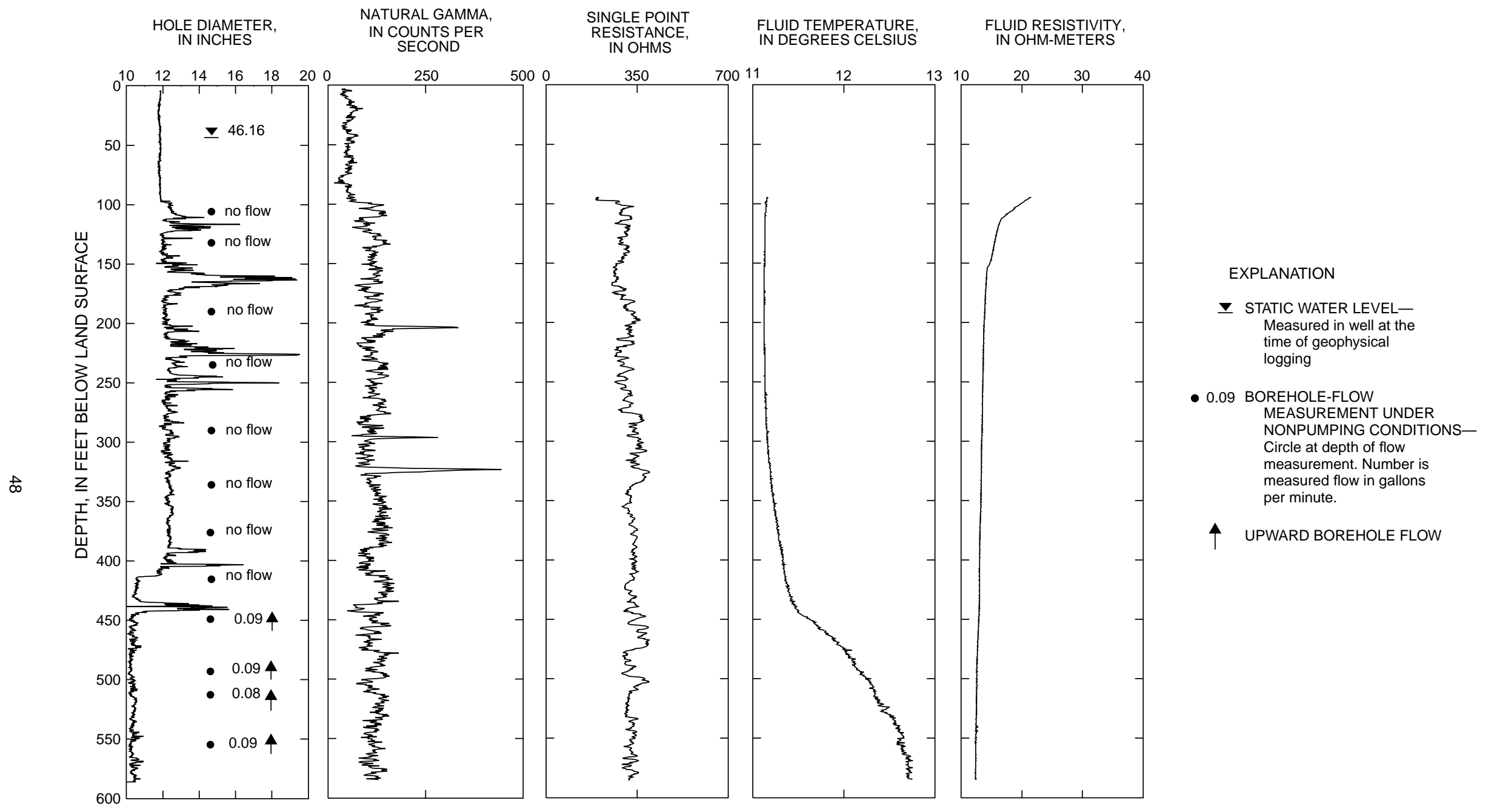

Figure 28. Borehole geophysical logs and direction of nonpumping flow within borehole MG-498 (L-23), North Penn Area 6 Superfund Site, Lansdale, Montgomery County, Pennsylvania. 


\section{MG-618}

The caliper and natural-gamma logs were collected in this borehole on October 3, 1991. The caliper log shows the total depth of the borehole is $338 \mathrm{ft}$ and it is cased with 6-in.-diameter casing to $29 \mathrm{ft}$ bls (fig. 29). The caliper log shows minor fractures at 47,49 , and $148 \mathrm{ft}$ bls. The static water level in the well at the time of logging was $69.48 \mathrm{ft}$ bls. The natural-gamma log shows thin units, possibly shale beds, with elevated gamma readings at 283-285 and 288-289.5 ft bls that might be used for stratigraphic correlation of geologic units with other wells. The dipmeter log shows the borehole deviates from vertical approximately $5 \mathrm{ft}$ to the southwest over the total length of the borehole (fig. 30).

The strike and dip of fracture planes were obtained from the acoustic televiewer. The results are shown on an equal-area stereonet with single points (poles) plotted in the lower hemisphere at right angles to the fracture planes. These poles indicate most fracture planes trend northeast-southwest (fig. 31). The greatest concentration of poles are near the center of figure 31, probably indicating shallow bedding planes. Fiftytwo possible bedding planes were identified, 38 planes dip to the northwest with an average strike and dip of N. $12^{\circ}$ E., $2^{\circ} \mathrm{NW}$.; 14 shallow bedding planes dip to the southeast with a strike and dip of N. $84^{\circ} \mathrm{E} .5^{\circ} \mathrm{SE}$. Thirteen high-angle fracture planes were identified in the borehole with an average strike and dip of N. $74^{\circ}$ E., $67^{\circ} \mathrm{SE}$.

The fluid-temperature and fluid-resistivity logs and heatpulse-flowmeter measurements were collected on September 6, 1995. The fluid-temperature log show changes in slope at 80, 142, and $326 \mathrm{ft}$ bls. The fluid-resistivity log shows changes in slope at 80 and $326 \mathrm{ft}$ bls. The changes in slope shown on the fluid-resistivity and fluid-temperature logs at 80 and $326 \mathrm{ft}$ bls could indicate small water-producing fractures. Under nonpumping conditions, the heatpulse flowmeter measured slight upward flow at 130 and $200 \mathrm{ft}$ bls but less than the lower limit of the flowmeter (table 18). A submersible pump was placed at $98 \mathrm{ft} \mathrm{bls}$, and the well was pumped at approximately $0.5 \mathrm{gal} / \mathrm{min}$. After $30 \mathrm{~min}$ of pumping, the water level declined $6.79 \mathrm{ft}$ before stabilizing. Heatpulse-flowmeter measurements were made during pumping at 105, 130,200 , and $315 \mathrm{ft}$ bls. Under pumping conditions, the heatpulse flowmeter measured no flow at 105, 130, 200 , and $315 \mathrm{ft}$ bls. The suite of borehole geophysical logs and heatpulse-flowmeter measurements suggest that during pumping conditions the greatest quantity of water probably enters the borehole through shallow-dipping bedding fractures at approximately $80 \mathrm{ft}$ bls.

Table 18. Summary of heatpulse-flowmeter measurements for borehole MG-618 at North Penn Area 6 Superfund Site, Lansdale, Montgomery County, Pennsylvania

[gal/min, gallon per minute]

\begin{tabular}{cccc}
\hline $\begin{array}{c}\text { Depth } \\
\text { (feet below } \\
\text { land surface) }\end{array}$ & $\begin{array}{c}\text { Flow rate } \\
\text { (gal/min) } \\
\text { nonpumping } \\
\text { conditions }\end{array}$ & $\begin{array}{c}\text { Flow } \\
\text { direction } \\
\text { nonpumping } \\
\text { conditions }\end{array}$ & $\begin{array}{c}\text { Flow rate } \\
\text { (gal/min) } \\
\text { pumping } \\
\text { conditions }\end{array}$ \\
\hline 105 & no flow & not determined & no flow \\
130 & $<0.01$ & up & no flow \\
200 & $<.01$ & up & no flow \\
315 & $<.01$ & not determined & no flow \\
\hline
\end{tabular}




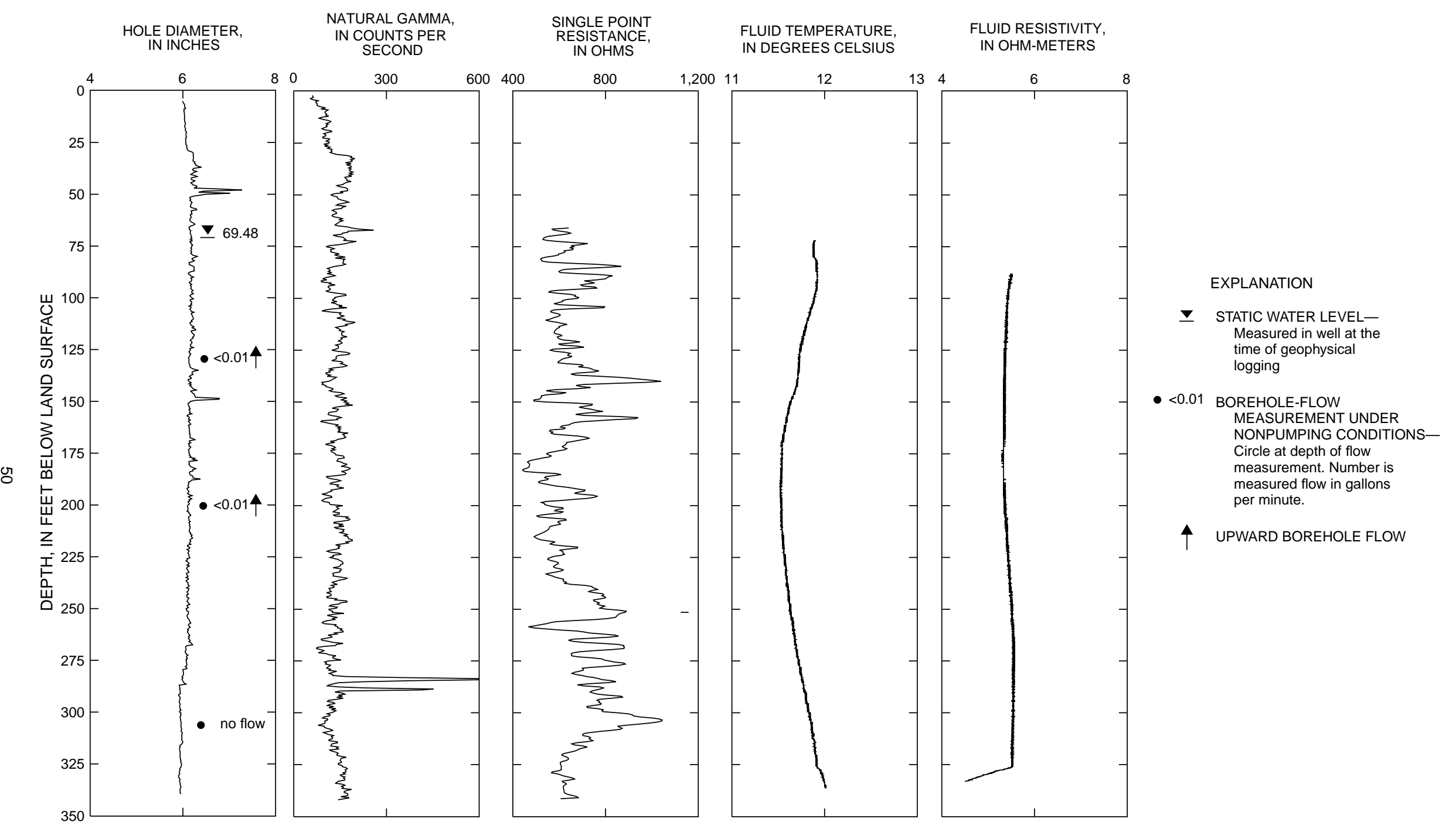

Figure 29. Borehole geophysical logs and direction of nonpumping flow within borehole MG-618, North Penn Area 6 Superfund Site, Lansdale, Montgomery County, Pennsylvania. 


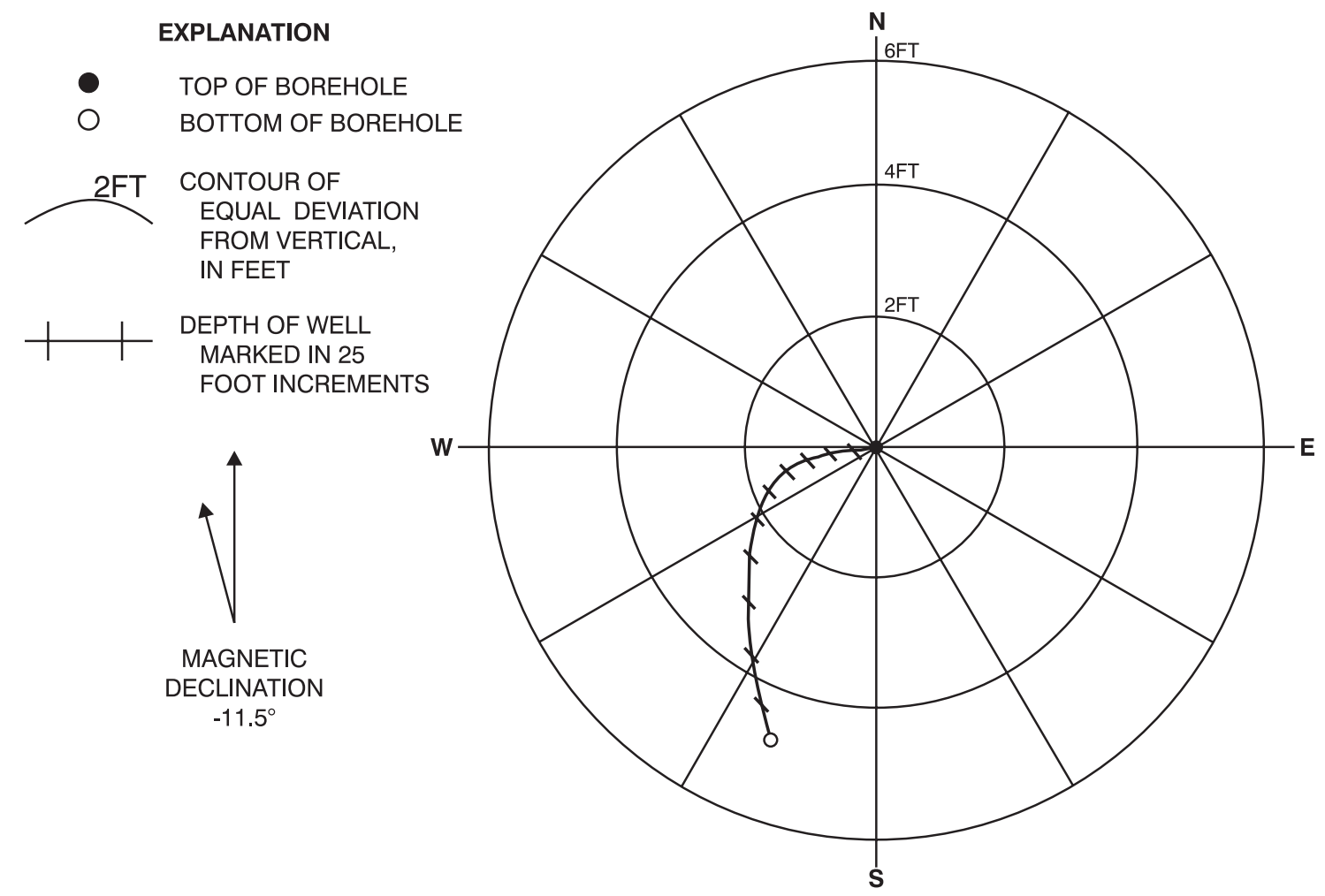

Figure 30. Magnitude and direction of deviation from vertical of borehole MG-618.

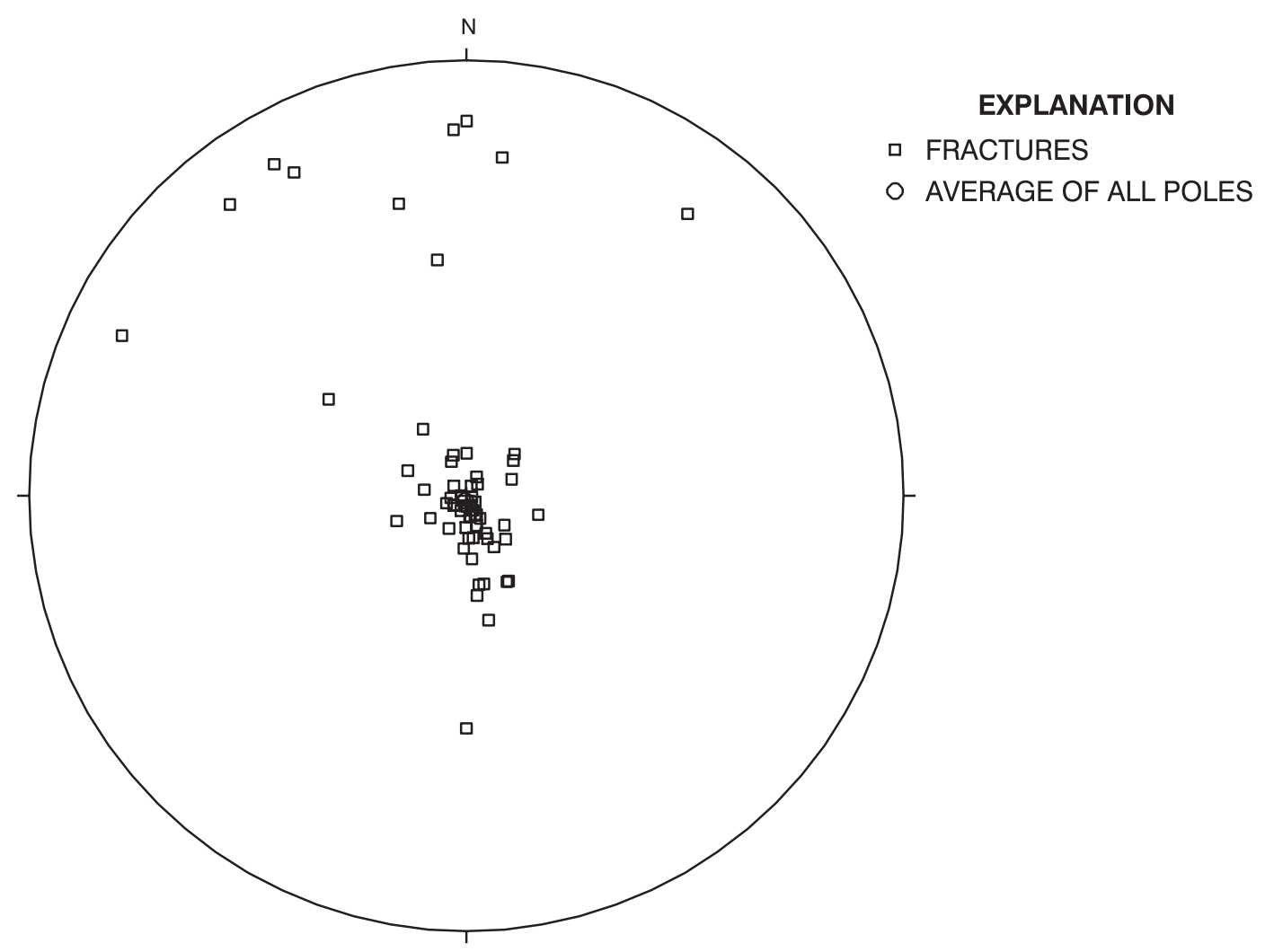

Figure 31. Equal-area lower hemisphere, stereographic projection of poles perpendicular to fracture planes in borehole MG-618. 


\section{MG-623 (L-24)}

The caliper log shows the total depth of the borehole is $505 \mathrm{ft}$ and it is cased with 10-in. diameter casing to $95 \mathrm{ft}$ bls (fig. 32). The caliper log shows major fracture zones at 119, 152-156, 162, 173-185, 186, 192-194, $318-321,331-335,338,357,384-387,410$, and $445-455 \mathrm{ft}$ bls plus numerous smaller fractures throughout the open-hole interval. The static water level at the time of logging was $26.99 \mathrm{ft}$ bls. The natural-gamma log shows a shale unit with elevated gamma readings at $470-479 \mathrm{ft}$ bls that might be used for stratigraphic correlation of geologic units with other wells. The fluid-temperature log shows a geothermal gradient from 80 to $503 \mathrm{ft}$ bls indicating the absence of borehole flow under nonpumping conditions. Therefore, heatpulse-flowmeter measurements were not taken. A submersible pump was placed at $45 \mathrm{ft} \mathrm{bls}$, and the well was pumped at increasing increments from 1 to $6 \mathrm{gal} / \mathrm{min}$. At a pumping rate of approximately $2.5 \mathrm{gal} / \mathrm{min}$, the water level slowly declined $0.84 \mathrm{ft}$ in 42 minutes. At a pumping rate of $6 \mathrm{gal} / \mathrm{min}$, the water level declined $1.3 \mathrm{ft}$ in 1 hour and 49 minutes, indicating most discharge water was derived from the formation and not from borehole storage. Under pumping conditions, the heatpulse flowmeter measured upward flow at 125, 134, 148, and $170 \mathrm{ft}$ bls (table 19). The heatpulse flowmeter measured minor upward flow at 208, 235, 260, 292, 312, and $370 \mathrm{ft}$ bls. The suite of borehole geophysical logs and heatpulseflowmeter measurements indicate the greatest quantity of water enters the borehole through the fractures between 95 and $185 \mathrm{ft}$ bls.

Table 19. Summary of heatpulse-flowmeter measurements for borehole MG-623 (L-24) at North Penn Area 6 Superfund Site, Lansdale, Montgomery County, Pennsylvania

[gal/min, gallon per minute]

\begin{tabular}{ccc}
\hline $\begin{array}{c}\text { Depth } \\
\text { (feet below } \\
\text { land surface) }\end{array}$ & $\begin{array}{c}\text { Flow rate } \\
\text { (gal/min) } \\
\text { pumping } \\
\text { conditions }\end{array}$ & $\begin{array}{c}\text { Flow } \\
\text { direction } \\
\text { pumping } \\
\text { conditions }\end{array}$ \\
\hline 125 & 0.32 & up \\
134 & .40 & up \\
148 & .25 & up \\
170 & .12 & up \\
208 & .04 & up \\
235 & .01 & up \\
260 & .01 & up \\
292 & .01 & up \\
312 & .01 & up \\
370 & .01 & up \\
\hline
\end{tabular}




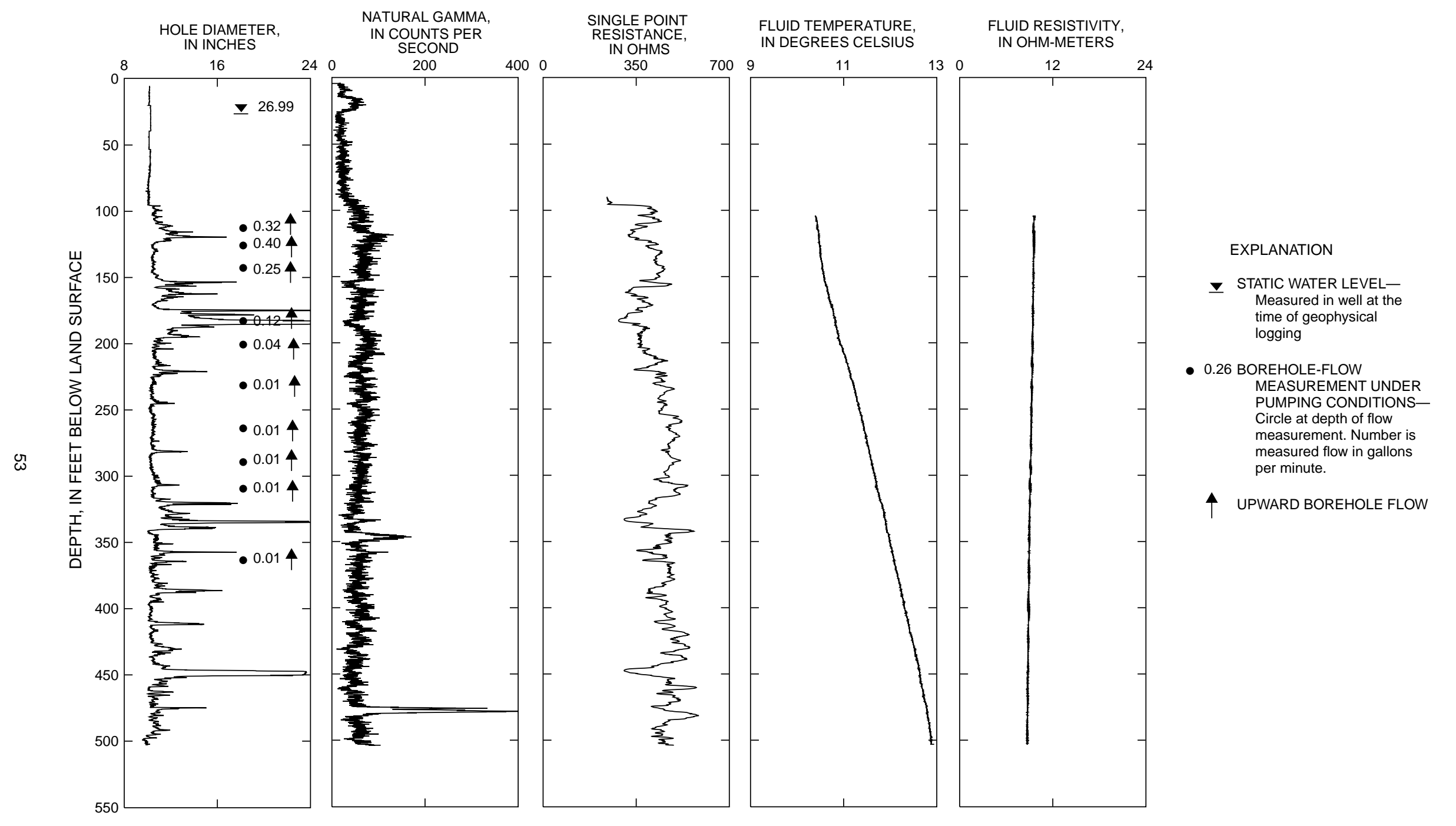

Figure 32. Borehole geophysical logs and direction of pumping flow within borehole MG-623 (L-24), North Penn Area 6 Superfund Site, Lansdale, Montgomery County, Pennsylvania. 


\section{MG-624 (J .W. Rex \#2)}

The caliper log shows the total depth of the borehole is $633 \mathrm{ft}$ and it is cased with 8-in.-diameter casing to $52 \mathrm{ft}$ bls (fig. 33). The caliper log shows major fracture zones at 119, 173, 193-204, and 612-618 ft bls plus numerous smaller fractures throughout the open-hole interval. The static water level at the time of logging was $21.47 \mathrm{ft}$ bls. The natural-gamma log shows thin units, possibly shale beds, with elevated gamma readings at 389-391, 417, and 420-423 ft bls that might be used for stratigraphic correlation of geologic units with other wells. The fluid-temperature and fluid-resistivity logs show an increase in temperature from 25$615 \mathrm{ft}$ bls, indicative of the geothermal gradient and suggesting an absence of borehole flow. A submersible pump was placed at $45 \mathrm{ft}$ bls, and the well was pumped at approximately $1 \mathrm{gal} / \mathrm{min}$. The water level in the well declined $9.53 \mathrm{ft}$ after 1 hour and $15 \mathrm{~min}$ of pumping and never completely stabilized during flowmetering. Under pumping conditions, the heatpulse flowmeter measured upward flow at 66, 78, 102, $134,160,182,214,238,278$, and $326 \mathrm{ft}$ bls; flow at $366 \mathrm{ft}$ bls was less than the minimum detection limit (table 20). During pumping, the depth to water continued to increase while heatpulse flowmetering at $66,78,102$, and $134 \mathrm{ft}$ bls; therefore, the flow measurements cannot be compared directly to discharge rate. Although the change was slow, the water level continued to decline while heatpulse-flowmeter measurements were made at 160, 182, 214, 238, 278, 326, and $366 \mathrm{ft}$ bls. The suite of borehole geophysical logs and heatpulseflowmeter measurements indicate the greatest quantity of water enters the borehole during pumping conditions through the fractures above $66 \mathrm{ft}$ bls.

Table 20. Summary of heatpulse-flowmeter measurements for borehole MG-624 (J.W. Rex \#2) at North Penn Area 6 Superfund Site, Lansdale, Montgomery County, Pennsylvania

[gal/min, gallon per minute; <, less than]

\begin{tabular}{ccccc}
\hline $\begin{array}{c}\text { Depth } \\
\text { (feet below } \\
\text { land surface) }\end{array}$ & $\begin{array}{c}\text { Flow rate } \\
\text { (gal/min) } \\
\text { nonpumping } \\
\text { conditions }\end{array}$ & $\begin{array}{c}\text { Flow } \\
\text { direction } \\
\text { nonpumping } \\
\text { conditions }\end{array}$ & $\begin{array}{c}\text { Flow rate } \\
\text { (gal/min) } \\
\text { pumping } \\
\text { conditions }\end{array}$ & $\begin{array}{c}\text { Flow } \\
\text { direction } \\
\text { pumping } \\
\text { conditions }\end{array}$ \\
\hline 66 & $<0.01$ & up & 0.08 & up \\
78 & no data & no data & .18 & up \\
100 & $<.01$ & up & no data & no data \\
102 & no data & no data & .23 & up \\
134 & no data & no data & .27 & up \\
160 & no data & no data & .17 & up \\
182 & no data & no data & .16 & up \\
214 & $<.01$ & up & .11 & up \\
238 & no data & no data & .11 & up \\
278 & no data & no data & .11 & up \\
322 & $<.01$ & up & no data & no data \\
326 & no data & no data & .02 & up \\
366 & no data & no data & $<.01$ & up \\
\hline
\end{tabular}




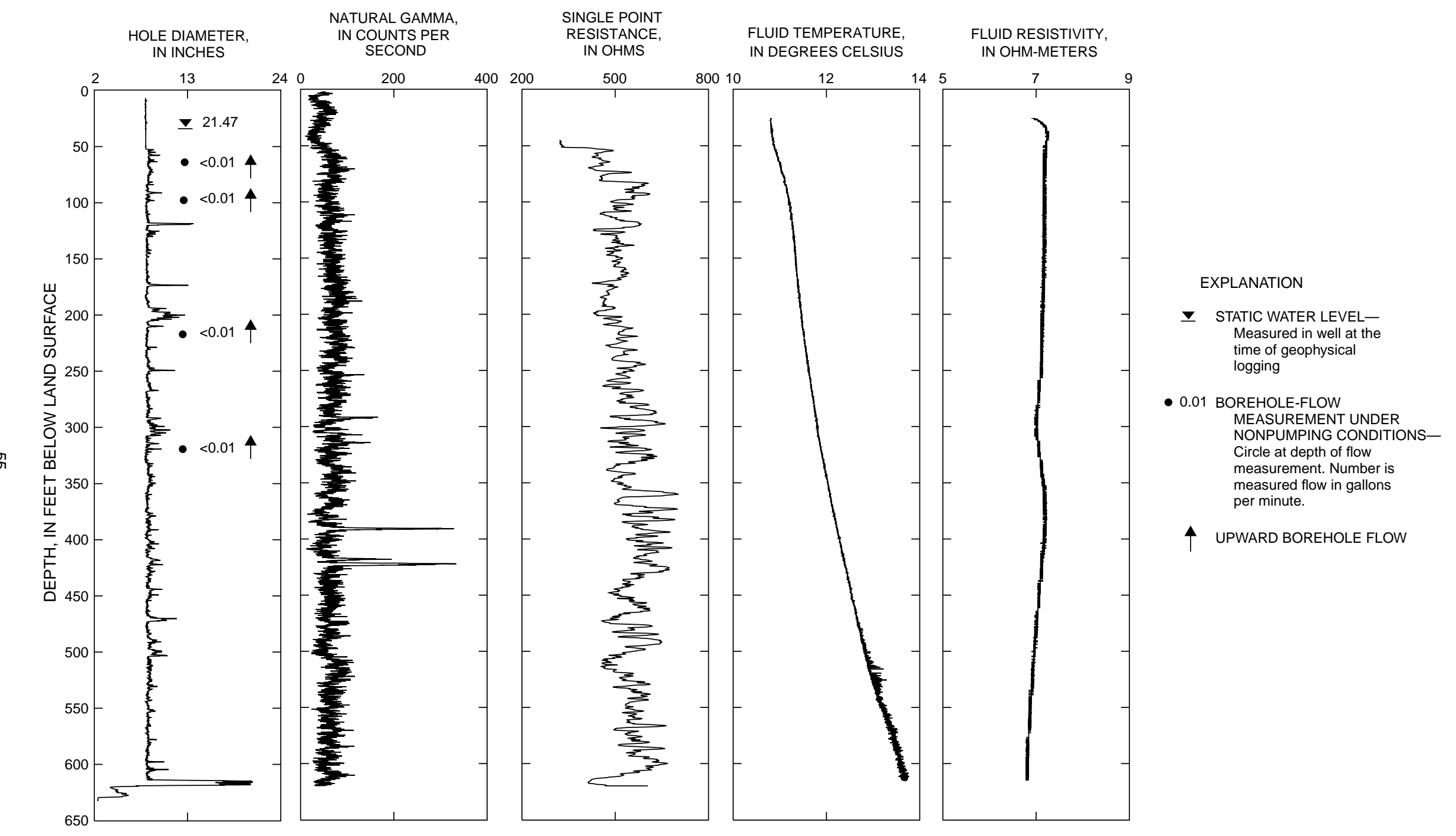

Figure 33. Borehole geophysical logs and direction of nonpumping flow within borehole MG-624 (J.W. Rex \#2), North Penn Area 6 Superfund Site, Lansdale, Montgomery County, Pennsylvania. 


\section{MG-704 (L-26)}

The caliper $\log$ shows the total depth of the borehole is $380 \mathrm{ft}$ and it is cased with 10-in.-diameter casing to $82 \mathrm{ft}$ bls (fig. 34). The caliper log shows major fracture zones at 82-84, 110-115, 249, and 350-352 ft bls plus numerous smaller fractures throughout the open-hole interval. The caliper probe hung up at $248 \mathrm{ft}$ bls, in an area seen as a large vertical fracture on the video log. The static water level before logging was $21.29 \mathrm{ft}$ bls. The natural-gamma log shows shale units with elevated gamma readings at 336-338 and 364$367 \mathrm{ft}$ bls that might be used for stratigraphic correlation of geologic units with other wells. The fluidtemperature and fluid-resistivity logs show a change in slope inside casing at $60 \mathrm{ft}$ bls that is probably caused by water flowing around the casing. The fluid-temperature and fluid-resistivity logs show a slight change in slope at $82 \mathrm{ft}$ bls that correlates to a fracture on the caliper log. A large change in slope is seen on the fluid-temperature $\log$ at $260 \mathrm{ft}$ bls and fluid-resistivity log at 100 and $300 \mathrm{ft}$ bls that may be the result of lateral flow through the borehole. A slug of high-conductance fluid was injected at 105, 130, 180, 270, and $315 \mathrm{ft}$ bls; no detectable borehole flow was measured. A submersible pump was placed at $60 \mathrm{ft}$ bls, and the well was pumped at $2 \mathrm{gal} / \mathrm{min}$. In an attempt to measure borehole flow, a modification was made to the heatpulse flowmeter to compensate for the 10-in.-diameter borehole; however, accurate flow could not be measured. The suite of borehole geophysical logs and brine-trace data indicate vertical borehole flow during nonpumping conditions does not exist or is too small to be measured.

\section{MG-1128 (NP-70)}

The caliper log shows the total depth of the borehole is $486 \mathrm{ft}$ and it is cased with 8-in.-diameter casing to $9 \mathrm{ft}$ bls (fig. 35). The caliper log shows major fractures and fracture zones at 10-16, 33, 70, 83, 118, 122, 203206, 215-223, 227-231, 304-306, and 462-464 ft bls plus numerous smaller fractures throughout the open-hole interval and a borehole constriction at $203 \mathrm{ft}$ bls. The static water level in the well at the time of logging was $18.34 \mathrm{ft}$ bls. The natural-gamma log shows a shale unit with a slightly elevated gamma reading at 216$218 \mathrm{ft}$ bls that might be used for stratigraphic correlation of geologic units with other wells. The fluidtemperature log shows major changes in slope at 33 and $72 \mathrm{ft}$ bls and minor slope changes at 203 and $300 \mathrm{ft}$ bls that correlate to fractures shown on the caliper log. The dipmeter log shows the borehole deviates approximately $28 \mathrm{ft}$ to the south-southwest over the total length of the borehole (fig. 36).

The strike and dip of fracture planes were obtained from the acoustic televiewer. The results are shown on an equal-area stereonet with single points (poles) plotted in the lower hemisphere at right angles to the fracture planes. These poles indicate that many fracture planes trend northwest-southeast (fig. 37). The greatest concentration of poles is near the center of figure 37, probably indicating shallow bedding planes. Forty-nine planar features were identified, 39 planes dip to the northeast with an average strike of N. $50^{\circ}$ W., $8^{\circ}$ NE., 10 shallow planes dip to the southwest with a strike and dip of N. $51^{\circ}$ W., $4^{\circ}$ SW. Fortythree higher-angle fracture planes were identified in the borehole with an average strike and dip of N. $79^{\circ}$ W., $22^{\circ}$ NE.

Under nonpumping conditions, the heatpulse flowmeter measured downward flow at $42,60,78,108$, 146, 180, 208, 236, and $264 \mathrm{ft}$ bls (table 21). A submersible pump was placed at $50 \mathrm{ft}$ bls, and the well was pumped at a rate of approximately $4 \mathrm{gal} / \mathrm{min}$. The water level in the well declined $2.11 \mathrm{ft}$ after 1 hour and 52 minutes of pumping and never completely stabilized, which indicates that part of the discharge was derived from borehole storage and part from the aquifer, resulting in a flow measurement less than the actual rate. The suite of borehole geophysical logs and heatpulse-flowmeter measurements indicate water enters the borehole through fractures at 33 and $70 \mathrm{ft}$ bls and exits the borehole through fractures at 118-137, $172,203-206,215-231$, and below $265 \mathrm{ft}$ bls. Under pumping conditions, the greatest quantity of water enters the borehole through fractures above $42 \mathrm{ft}$ bls and 83-137 ft bls. 


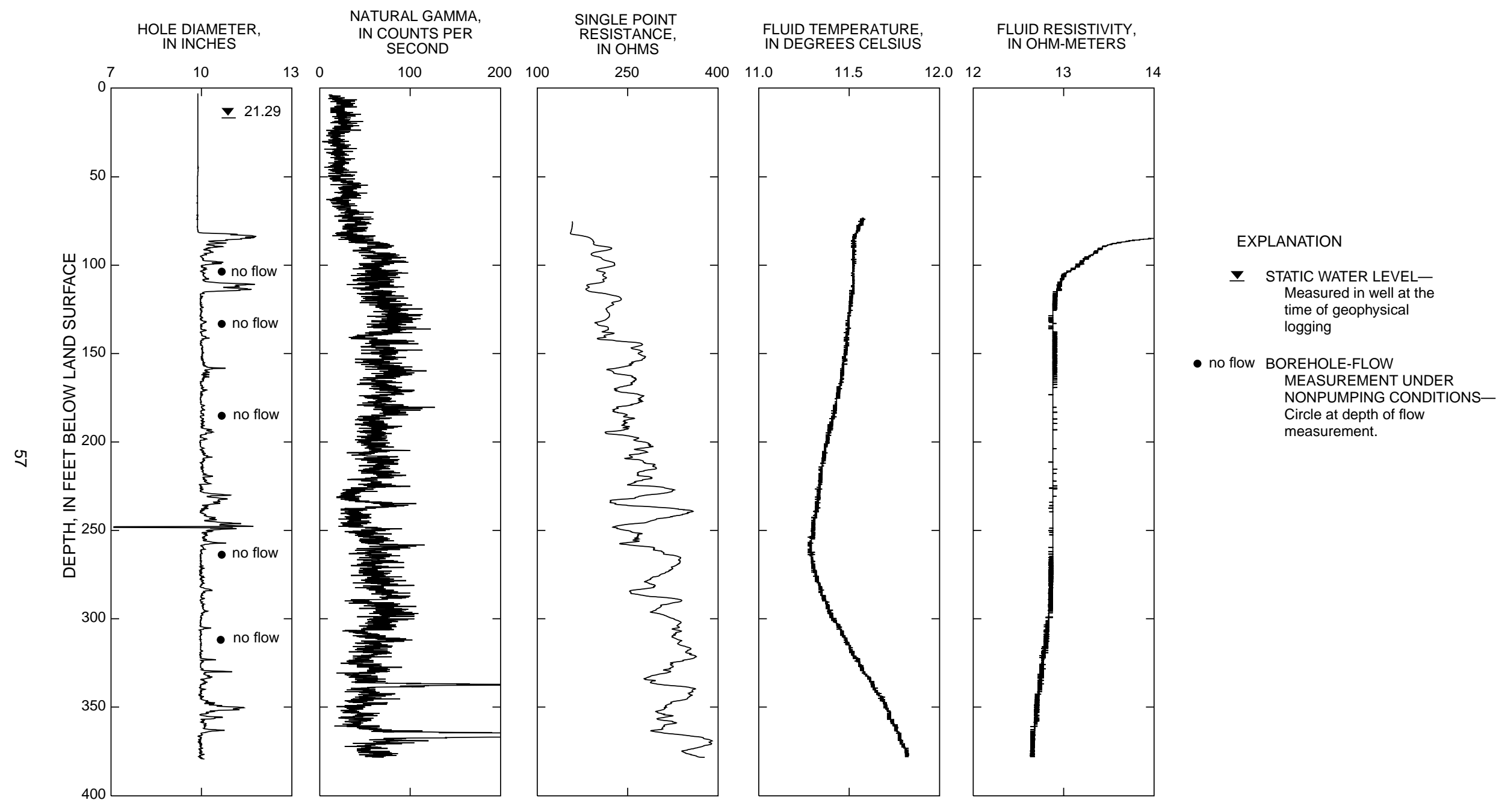

Figure 34. Borehole geophysical logs and direction of nonpumping flow within borehole MG-704 (L-26), North Penn Area 6 Superfund Site, Lansdale, Montgomery County, Pennsylvania. 


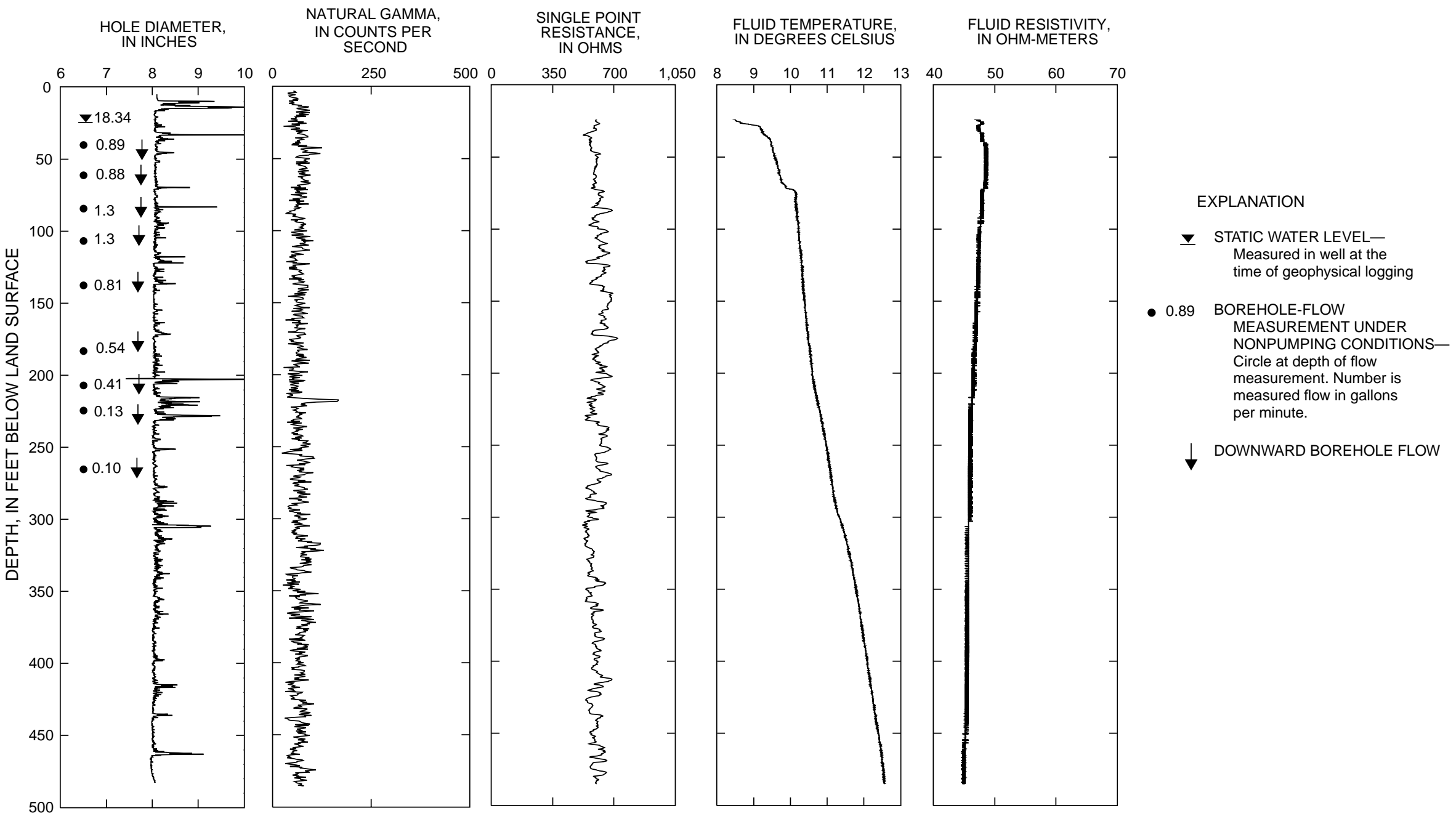

Figure 35. Borehole geophysical logs and direction of nonpumping flow within borehole MG-1128 (NP-70), North Penn Area 6 Superfund Site, Lansdale, Montgomery County, Pennsylvania. 


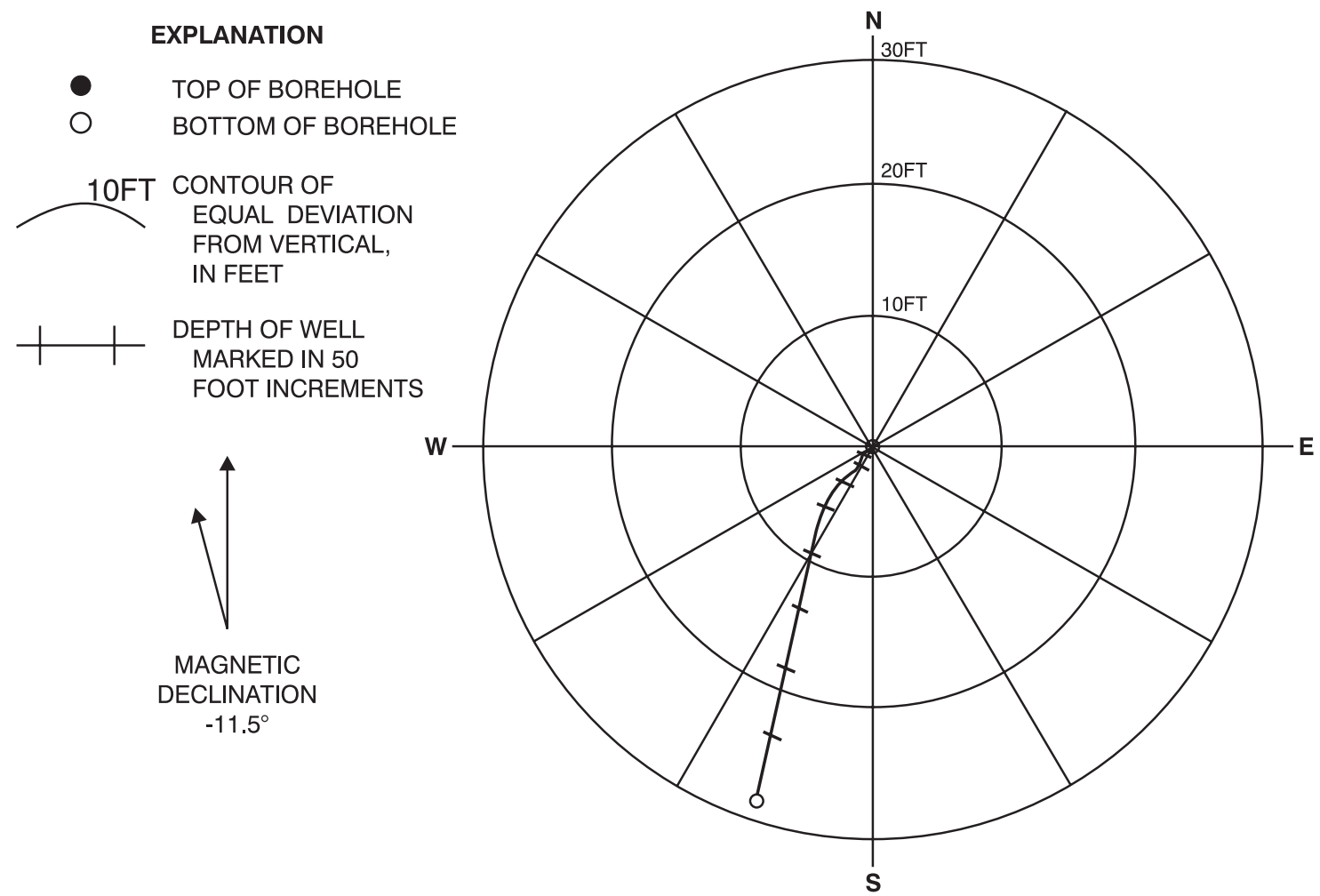

Figure 36. Magnitude and direction of deviation from vertical of borehole MG-1128 (NP-70).

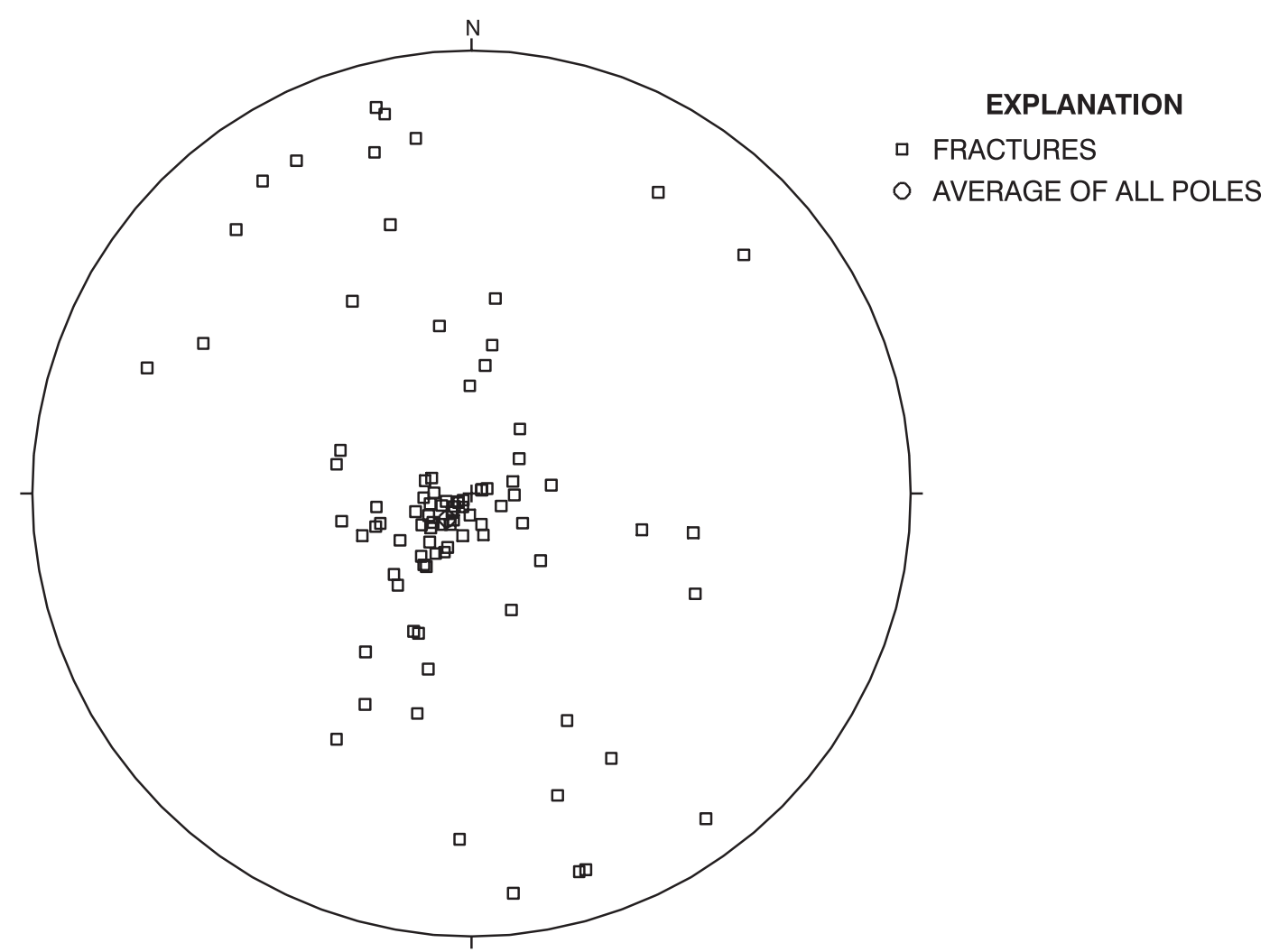

Figure 37. Equal-area lower hemisphere, stereographic projection of poles perpendicular to fracture planes in borehole MG-1128 (NP-70). 
Table 21. Summary of heatpulse-flowmeter measurements for borehole MG-1128 (NP-70) at North Penn Area 6 Superfund Site, Lansdale, Montgomery County, Pennsylvania [gal/min, gallon per minute]

\begin{tabular}{ccccc}
\hline $\begin{array}{c}\text { Depth } \\
\text { feet below } \\
\text { land surface) }\end{array}$ & $\begin{array}{c}\text { Flow rate } \\
\text { (gal/min) } \\
\text { nonpumping } \\
\text { conditions }\end{array}$ & $\begin{array}{c}\text { Flow } \\
\text { direction } \\
\text { nonpumping } \\
\text { conditions }\end{array}$ & $\begin{array}{c}\text { Flow rate } \\
\text { (gal/min) } \\
\text { pumping } \\
\text { conditions }\end{array}$ & $\begin{array}{c}\text { Flow } \\
\text { direction } \\
\text { pumping } \\
\text { conditions }\end{array}$ \\
\hline 42 & 0.89 & down & no data & no data \\
60 & .88 & down & 1.0 & up \\
78 & 1.3 & down & .84 & up \\
108 & 1.3 & down & .52 & up \\
146 & .81 & down & .12 & up \\
180 & .54 & down & .08 & up \\
208 & .41 & down & no data & no data \\
236 & .13 & down & no data & no data \\
264 & .10 & down & no data & no data \\
\hline
\end{tabular}

\section{MG-1284 (NP-68)}

The caliper $\log$ shows the total depth of the borehole is $442 \mathrm{ft}$ and it is cased with 10-in.-diameter casing to $82 \mathrm{ft}$ bls (fig. 38). The caliper log shows major fracture zones at 90-92, 255-257, and 275-279 ft bls plus numerous other fractures throughout the borehole. The static water level in the well at the time of logging was $9.42 \mathrm{ft}$ bls. The fluid-resistivity log shows changes in slope at 92 and $110 \mathrm{ft}$ bls that correlate to fractures shown on the caliper log. The fluid-temperature log shows a change in slope at $304 \mathrm{ft}$ bls that correlates to a fracture shown on the caliper log. Under nonpumping conditions, the heatpulse flowmeter measured upward flow at 88, 96, 120, 160, 210, 246, 270, 286, 310, 350, 400, and $426 \mathrm{ft}$ bls (table 22). A submersible pump was placed at $40 \mathrm{ft}$ bls, and the well was pumped at $4 \mathrm{gal} / \mathrm{min}$. The water level in the well declined $1.79 \mathrm{ft}$ after $7 \mathrm{~min}$ of pumping then began to stabilize. Because the borehole diameter exceeds the 8-in. maximum recommended by the heatpulse-flowmeter manufacturer, all flow measurements should be considered relative estimates. Under nonpumping conditions, the suite of borehole geophysical logs and heatpulse-flowmeter measurements indicate water enters the borehole through fractures at 438 and $292 \mathrm{ft} \mathrm{bls}$, moves upward, and exits the borehole through fractures at 256, 90-92, and $82 \mathrm{ft} \mathrm{bls}$. Under pumping conditions, the greatest quantity of water enters the borehole through fractures at 99-103 and 224$238 \mathrm{ft}$ bls. 


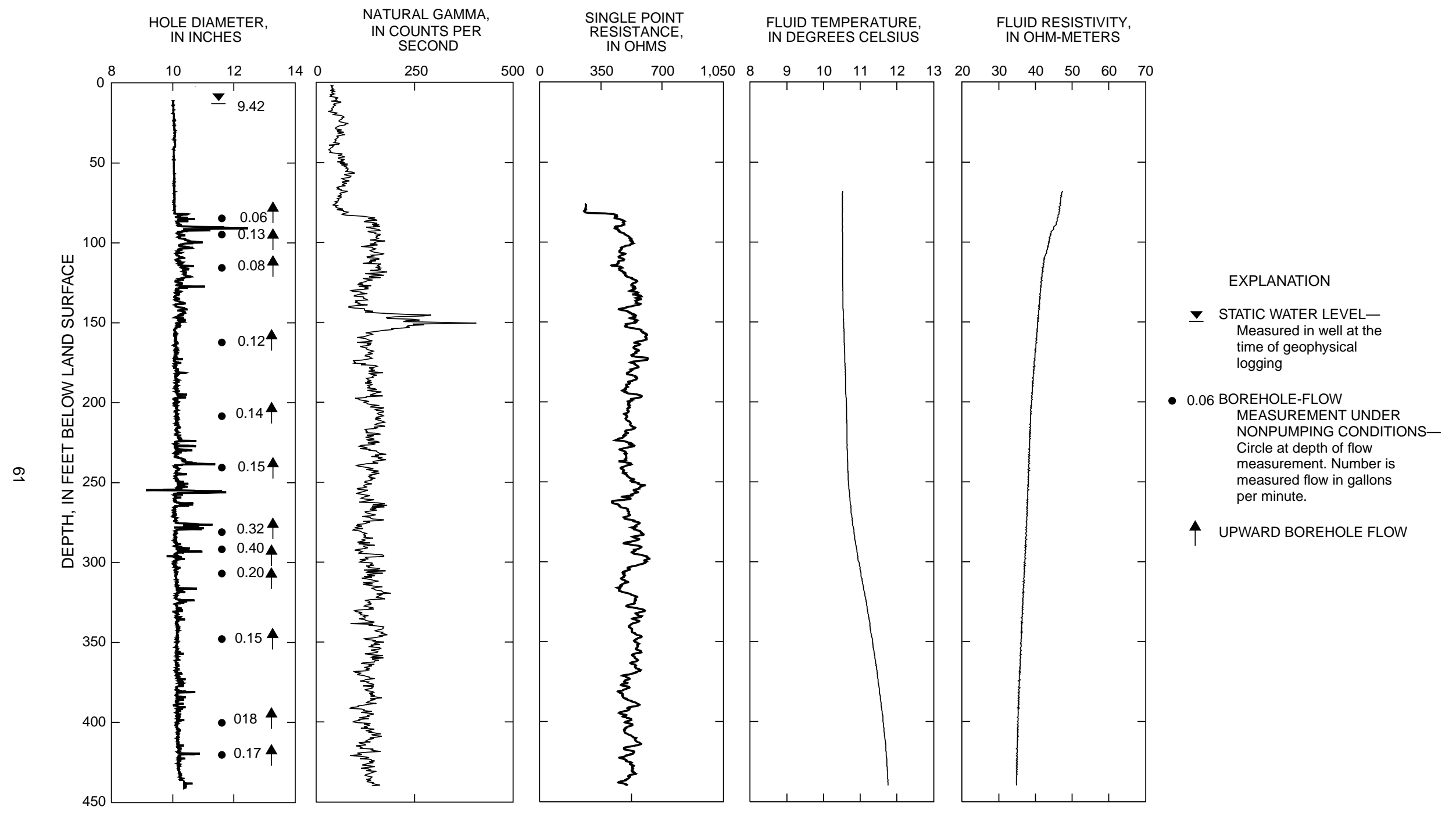

Figure 38. Borehole geophysical logs and direction of nonpumping flow within borehole MG-1284 (NP-68), North Penn Area 6 Superfund Site, Lansdale, Montgomery County, Pennsylvania. 
Table 22. Summary of heatpulse-flowmeter measurements for borehole MG-1284 (NP-68) at North Penn Area 6 Superfund Site, Lansdale, Montgomery County, Pennsylvania

[gal/min, gallon per minute]

\begin{tabular}{ccccc}
\hline $\begin{array}{c}\text { Depth } \\
\text { (feet below } \\
\text { land surface) }\end{array}$ & $\begin{array}{c}\text { Flow rate } \\
\text { (gal/min) } \\
\text { nonpumping } \\
\text { conditions }\end{array}$ & $\begin{array}{c}\text { Flow } \\
\text { direction } \\
\text { nonpumping } \\
\text { conditions }\end{array}$ & $\begin{array}{c}\text { Flow rate } \\
\text { (gal/min) } \\
\text { pumping } \\
\text { conditions }\end{array}$ & $\begin{array}{c}\text { Flow } \\
\text { direction } \\
\text { pumping } \\
\text { conditions }\end{array}$ \\
\hline 70 & no data & no data & ${ }^{1} 0.49$ & up \\
80 & no data & no data & .27 & up \\
88 & 0.06 & up & $.44-.52$ & up \\
96 & .13 & up & .48 & up \\
120 & .08 & up & .29 & up \\
160 & .12 & up & .33 & up \\
190 & no data & no data & .30 & up \\
210 & .14 & up & .16 & up \\
246 & .15 & up & .12 & up \\
270 & .32 & up & no data & no data \\
286 & .40 & up & no data & no data \\
310 & .20 & up & no data & no data \\
350 & .15 & up & no data & no data \\
400 & .18 & up & no data & no data \\
426 & .17 & up &
\end{tabular}
diameter.

${ }^{1}$ Calibrations measurements are much less than the actual discharge rate because of the large borehole

\section{MG-1440 (Crystal Soap)}

The caliper log shows the total depth of the borehole is $208 \mathrm{ft}$ and it is cased with 6 in.-diameter casing (fig. 39). The caliper $\log$ shows major fracture zones at 50, 59-60, 73, 102, 108, 128, and $162 \mathrm{ft}$ bls plus numerous smaller fractures throughout the open-hole interval. The static water level at the time of logging was $32.45 \mathrm{ft}$ bls. The natural-gamma log shows a shale unit with elevated gamma readings at 126-128 $\mathrm{ft}$ bls that might be used for stratigraphic correlation of geologic units with other wells. The fluid-temperature log shows almost no gradient from 109 to $128 \mathrm{ft}$ bls, indicating a zone of borehole flow. The fluidtemperature and fluid-resistivity logs show a change in slope at $108 \mathrm{ft}$ bls that correlates to a fracture on the caliper log. The fluid-temperature log also shows deflections in slope at 128 and $162 \mathrm{ft}$ bls that correlate to fractures on the caliper log. Under nonpumping conditions, the heatpulse flowmeter measured minor downward flow at 64 and $118 \mathrm{ft}$ bls; no flow at 146 and $183 \mathrm{ft}$ bls (table 23). Under nonpumping conditions, water enters the borehole through a fracture at $108 \mathrm{ft}$ bls, moves down, and exits the borehole through a fracture at $128 \mathrm{ft}$ bls. A submersible pump was placed at $44 \mathrm{ft}$ bls, and the well was pumped at approximately $1 \mathrm{gal} / \mathrm{min}$. During pumping, the water level declined $0.31 \mathrm{ft}$ in 1 hour, indicating most discharge water was derived from the formation and not from borehole storage. Under pumping conditions, the heatpulse flowmeter measured upward flow at 48, 55, 64, 80, and $98 \mathrm{ft}$ bls, downward flow at $118 \mathrm{ft}$ bls, and no flow at 146 or $183 \mathrm{ft}$ bls. The suite of borehole geophysical logs and heatpulse-flowmeter measurements indicate most discharge water enters the borehole through the fracture at $108 \mathrm{ft}$ bls and near $44 \mathrm{ft}$ bls. 


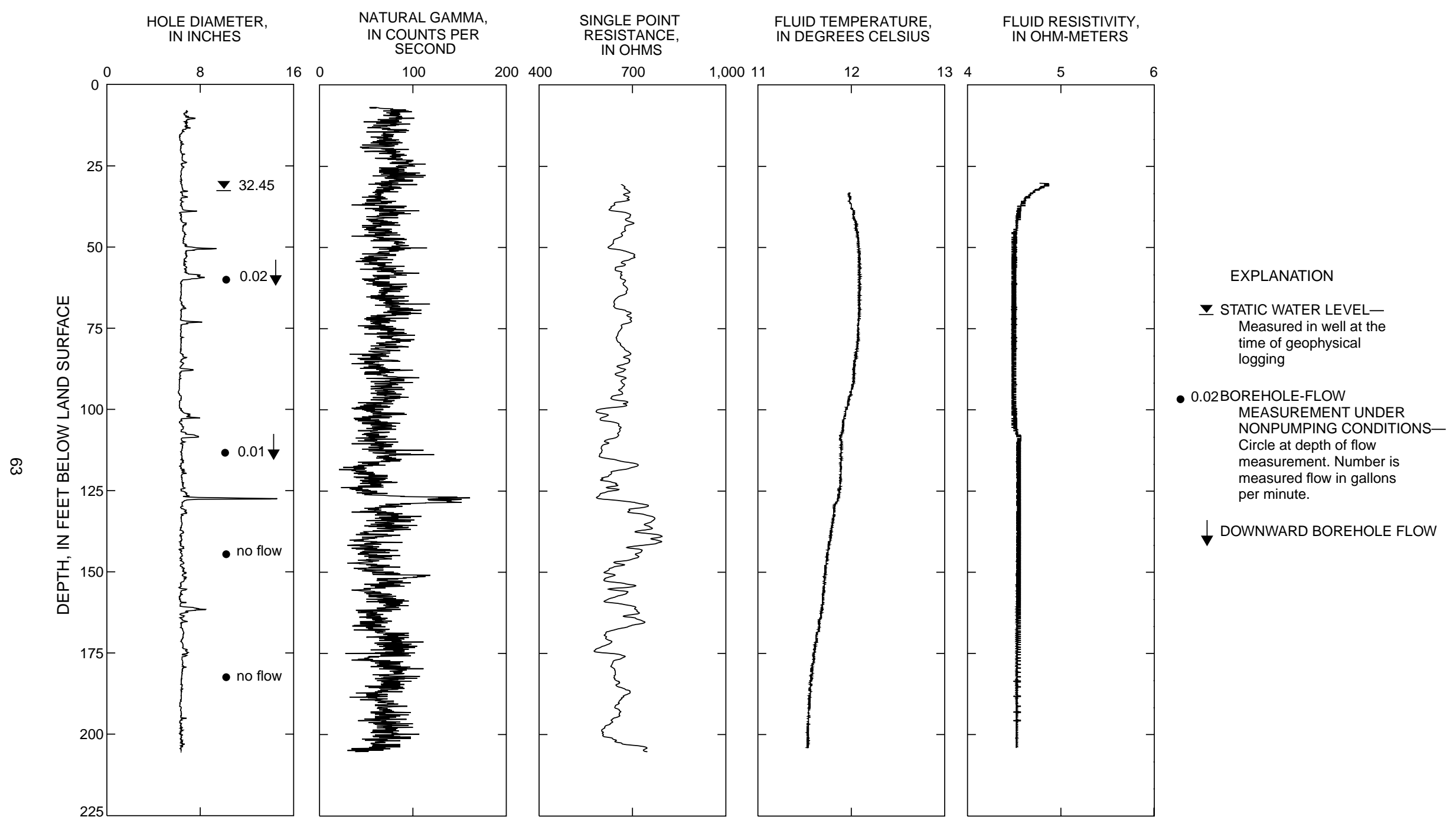

Figure 39. Borehole geophysical logs and direction of nonpumping flow within borehole MG-1440 (Crystal Soap), North Penn Area 6 Superfund Site, Lansdale, Montgomery County, Pennsylvania. 
Table 23. Summary of heatpulse-flowmeter measurements for borehole MG-1440 (Crystal Soap) at North Penn Area 6 Superfund Site, Lansdale, Montgomery County, Pennsylvania [gal/min, gallon per minute]

\begin{tabular}{ccccc}
\hline $\begin{array}{c}\text { Depth } \\
\text { (feet below } \\
\text { land surface) }\end{array}$ & $\begin{array}{c}\text { Flow rate } \\
\text { (gal/min) } \\
\text { nonpumping } \\
\text { conditions }\end{array}$ & $\begin{array}{c}\text { Flow } \\
\text { direction } \\
\text { nonpumping } \\
\text { conditions }\end{array}$ & $\begin{array}{c}\text { Flow rate } \\
\text { (gal/min) } \\
\text { pumping } \\
\text { conditions }\end{array}$ & $\begin{array}{c}\text { Flow } \\
\text { direction } \\
\text { pumping } \\
\text { conditions }\end{array}$ \\
\hline 48 & no data & no data & 0.27 & up \\
55 & no data & no data & .23 & up \\
64 & 0.02 & down & .19 & up \\
80 & no data & no data & .26 & up \\
98 & no data & no data & .26 & up \\
118 & .01 & down & .02 & down \\
146 & no flow & not determined & no flow & not determined \\
183 & no flow & not determined & no flow & not determined \\
\hline
\end{tabular}

\section{MG-1441 (MW-1)}

The caliper log shows the total depth of the borehole is $178 \mathrm{ft}$ and it is cased with 6-in.-diameter casing to $19 \mathrm{ft}$ bls (fig. 40). The caliper log shows major fracture zones at 153-157 and $161 \mathrm{ft}$ bls plus numerous smaller fractures throughout the open-hole interval. The static water level at the time of logging was $32.45 \mathrm{ft}$ bls. The dipmeter $\log$ shows the borehole deviates from vertical approximately $6 \mathrm{ft}$ to the southeast over the total length of the borehole (fig. 41).

The strike and dip of fracture planes was obtained from the acoustic televiewer. The results are shown on an equal-area stereonet with single points (poles) plotted in the lower hemisphere at right angles to the fracture planes. These poles indicate that many fracture planes trend northeast-southwest (fig. 42). The greatest concentration of poles is near the center of figure 42, probably indicating shallow bedding planes. Twenty-two possible bedding planes were identified, 17 planes dip to the northeast with an average strike of N. $55^{\circ}$ E., $5^{\circ} \mathrm{NW}$., which is nearly coincident with regional strike and dip; 5 shallow bedding planes dip to the southeast with a strike and dip of N. $47^{\circ}$ E., $8^{\circ} \mathrm{SE}$. Fourteen high-angle fracture planes were identified in the borehole.

The fluid-temperature and fluid-resistivity logs show changes in slope at 85, 118, and $164 \mathrm{ft}$ bls that correlate to fractures on the caliper log and video log. The fluid-temperature log shows almost no gradient from 85-118 and 118-161 ft bls, indicating zones of borehole flow. The well was not pumped and flowmetered because water-producing zones were identified under nonpumping conditions. The suite of borehole geophysical logs and heatpulse-flowmeter measurements indicate water enters the borehole through fractures at $85 \mathrm{ft}$ bls and moves downward. Additional water enters the borehole through a fracture at $118 \mathrm{ft}$ bls, moves downward, and exits the borehole through the fracture at $161 \mathrm{ft}$ bls (table 24). Nearby pumping of production wells may affect local ground-water flow.

Table 24. Summary of heatpulse-flowmeter measurements for borehole MG-1441 (MW-1) at North Penn Area 6 Superfund Site, Lansdale, Montgomery County, Pennsylvania [gal/min, gallons per minute]

\begin{tabular}{ccc}
\hline $\begin{array}{c}\text { Depth } \\
\text { (feet below } \\
\text { land surface) }\end{array}$ & $\begin{array}{c}\text { Flow rate } \\
\text { (gal/min) } \\
\text { nonpumping } \\
\text { conditions }\end{array}$ & $\begin{array}{c}\text { Flow } \\
\text { direction } \\
\text { nonpumping } \\
\text { conditions }\end{array}$ \\
\hline 100 & 0.23 & down \\
130 & .44 & down \\
\hline
\end{tabular}




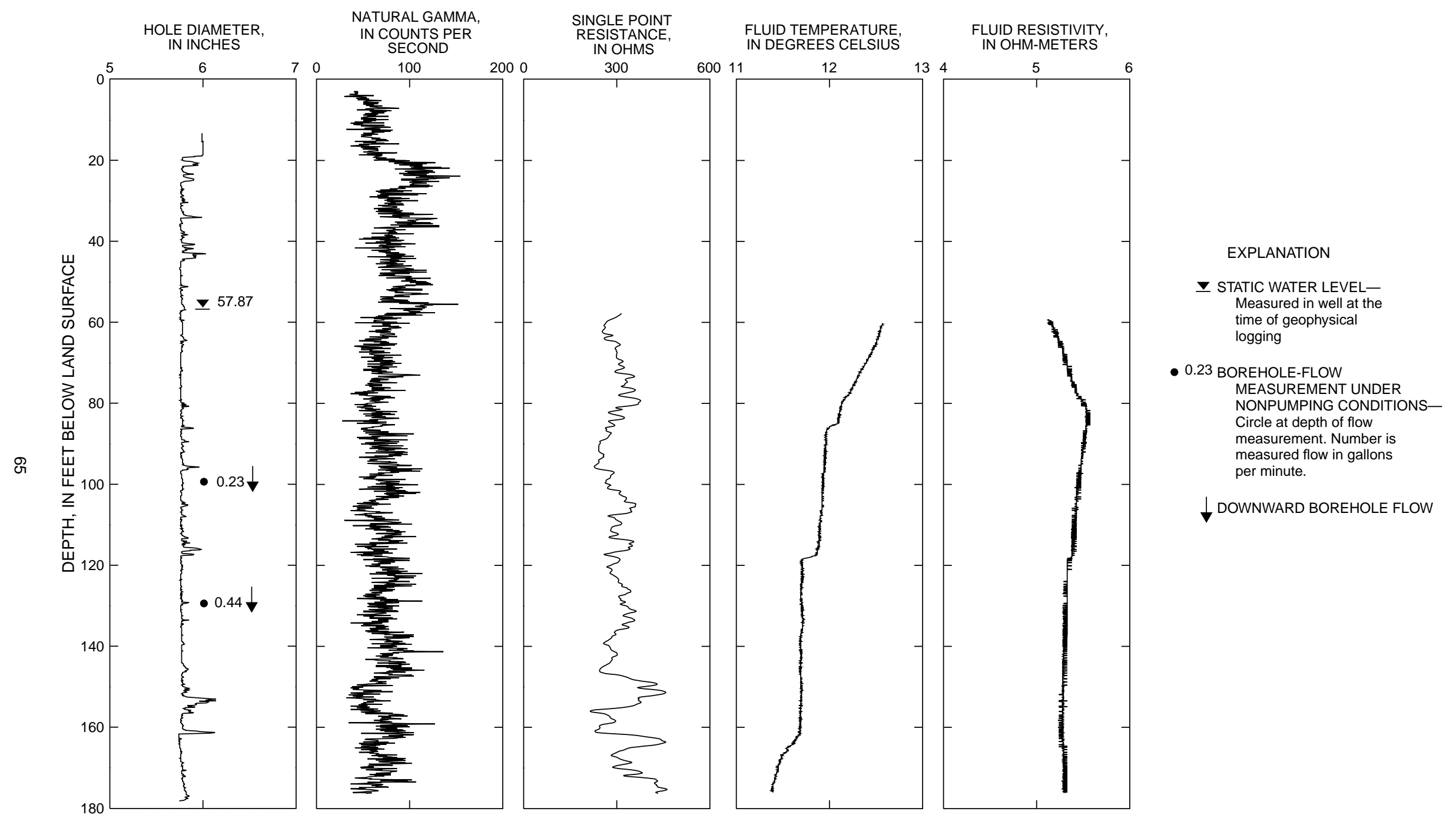

Figure 40. Borehole geophysical logs and direction of nonpumping flow within borehole MG-1441 (MW-1), North Penn Area 6 Superfund Site, Lansdale, Montgomery County, Pennsylvania. 


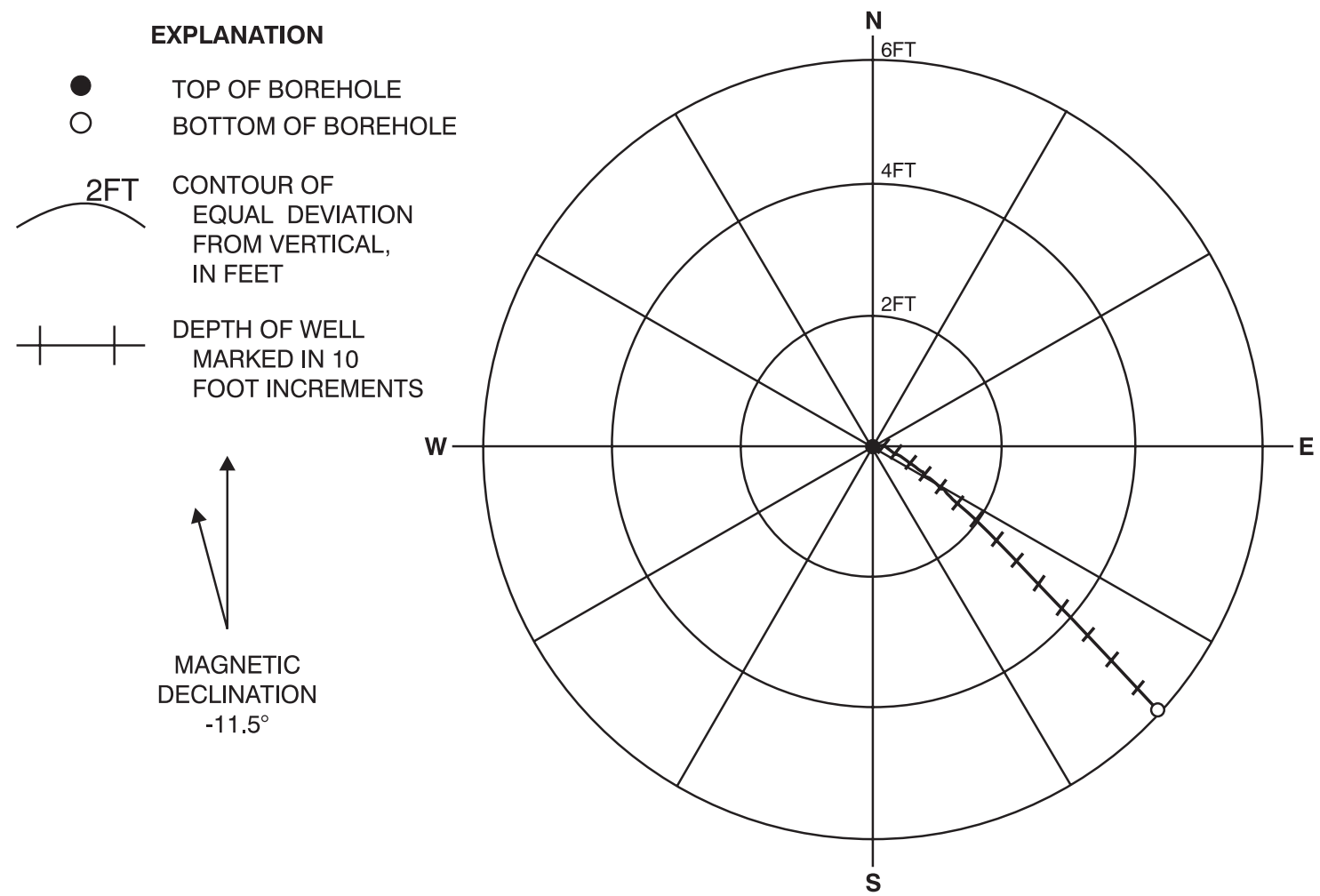

Figure 41. Magnitude and direction of deviation from vertical of borehole MG-1441 (MW-1).

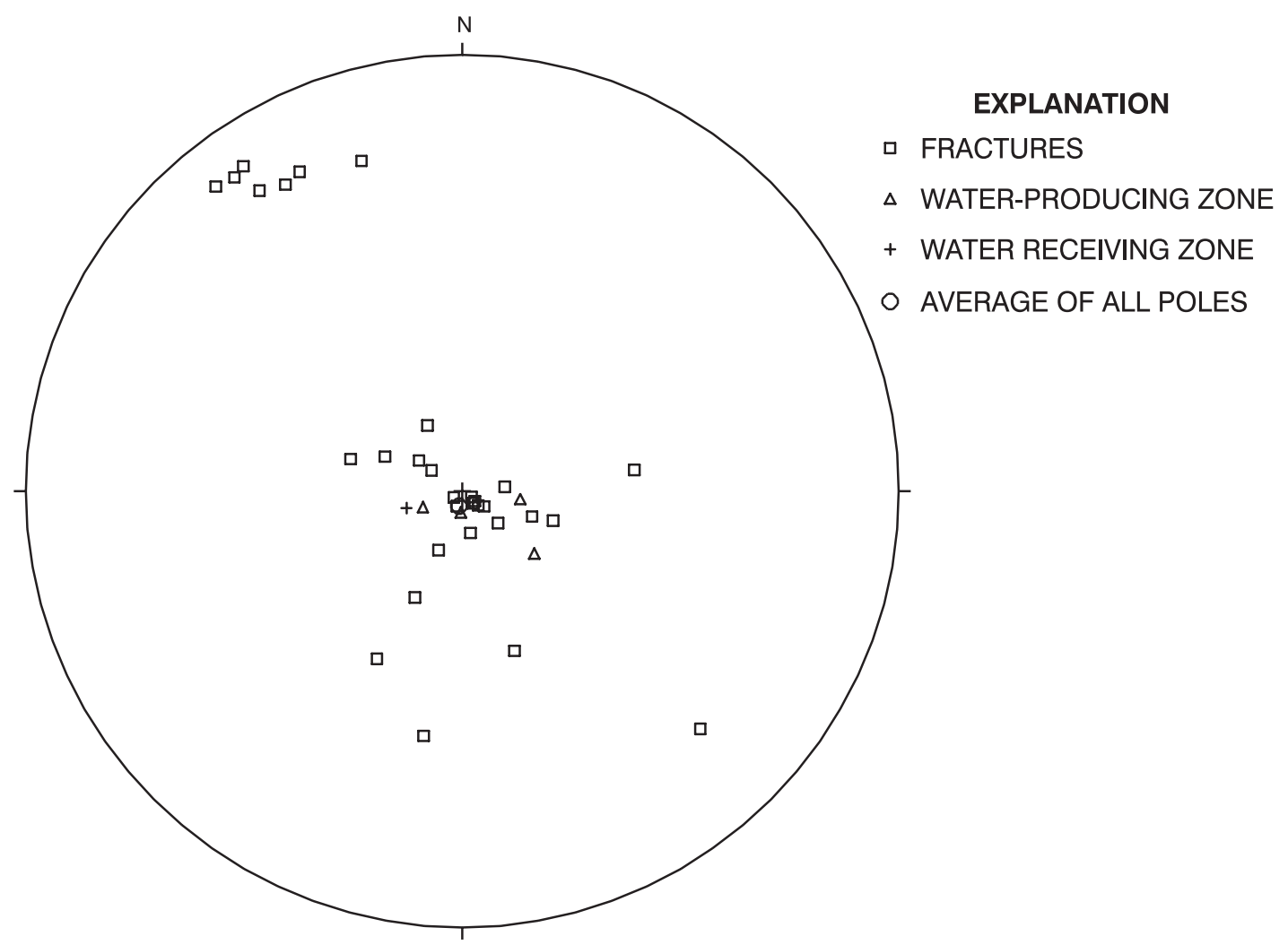

Figure 42. Equal-area lower hemisphere, stereographic projection of poles perpendicular to fracture planes in borehole MG-1441 (MW-1). 


\section{MG-1442 (LB-3)}

A gamma log only was collected in this 84 -ft borehole because it was already completed as a screened monitoring well at the time of geophysical logging (fig. 43). The gamma log was run to provide lithologic information. No zones of greater than normal gamma activity were measured in the borehole. The static water level at the time of logging was $57.48 \mathrm{ft}$ bls.

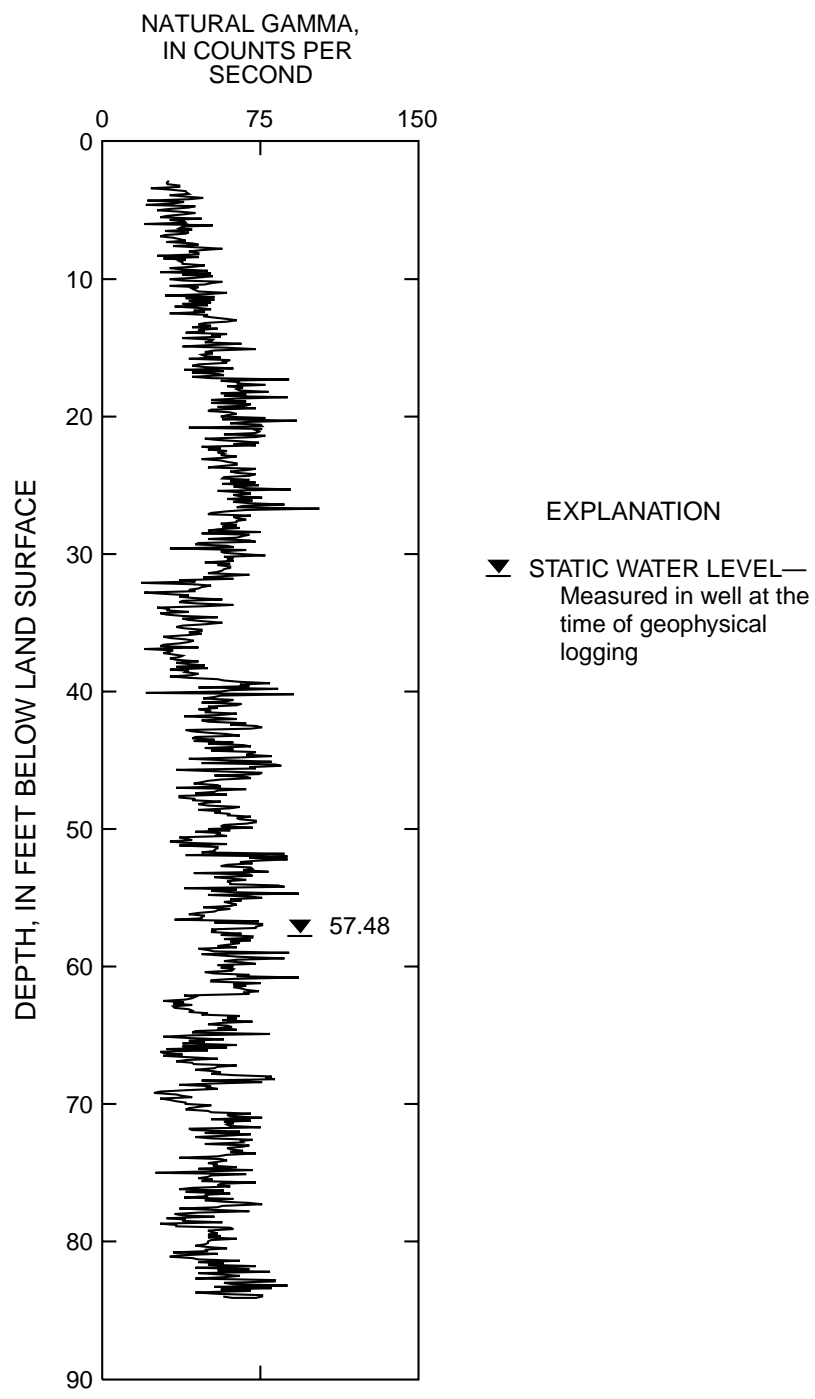

Figure 43. Natural-gamma log for borehole MG-1442 (LB-3), North Penn Area 6 Superfund

Site, Lansdale, Montgomery County, Pennsylvania. 


\section{MG-1443 (Philadelphia Toboggan and Coaster Company)}

The caliper log shows the total depth of the borehole is $339 \mathrm{ft}$ and it is cased with 8-in.-diameter casing to $10 \mathrm{ft}$ bls (fig. 44). The caliper log shows major fracture zones at 35-41, 104-106, 175-178, and 289-291 ft bls plus numerous other fractures throughout the borehole. The static water level in the well at the time of logging was $42.09 \mathrm{ft}$ bls. The natural-gamma log shows a shale unit with an elevated gamma reading at 323$325 \mathrm{ft}$ bls that might be used for stratigraphic correlation of geologic units with other wells. The dipmeter $\log$ shows the borehole deviates from vertical approximately $14 \mathrm{ft}$ to the southeast over the total length of the borehole (fig. 45).

The strike and dip of fracture planes was obtained from the acoustic televiewer. The results are shown on an equal-area stereonet with single points (poles) plotted in the lower hemisphere at right angles to the fracture planes. These poles indicate many fracture planes trend northeast-southwest (fig. 46). The greatest concentration of poles is near the center of figure 46, probably indicating shallow bedding planes. Fortytwo possible bedding planes were identified. Twenty-seven planes dip to the northwest with an average strike and dip of N. $80^{\circ}$ E., $7^{\circ} \mathrm{NW}$., which is approximately coincident with regional strike and dip. Fifteen shallow planes dip to the southeast with a strike and dip of N. $65^{\circ}$ E., $8^{\circ} \mathrm{SE}$. Forty high-angle fracture planes were identified in the borehole.

The fluid-temperature and fluid-resistivity log shows a change in slope at $55-80 \mathrm{ft}$ bls that correlates to fractures shown on the caliper log. Under nonpumping conditions, the heatpulse flowmeter measured upward flow at 68, 90, 124, 154, 200, 250, 275, 320, and $332 \mathrm{ft}$ bls (table 25). A submersible pump was placed at $55 \mathrm{ft}$ bls, and the well was pumped at slightly less than $1 \mathrm{gal} / \mathrm{min}$. The water level in the well declined $5.26 \mathrm{ft}$ after 1 hour and 38 min of pumping. Because the water level did not stabilize during pumping, part of the discharge was derived from borehole storage and part from the aquifer, resulting in a flow measurement less than the actual rate. Under nonpumping conditions, the suite of borehole geophysical logs and heatpulse-flowmeter measurements indicate water enters the borehole through fractures below $332 \mathrm{ft} \mathrm{bls}$, moves upward, and exits the borehole through fractures located at depths of approximately 225, $175-195,104-106$, and above $68 \mathrm{ft}$ bls. Under pumping conditions, the greatest quantity of water enters the borehole through fractures at 289-291 ft bls.

Table 25. Summary of heatpulse-flowmeter data for borehole MG-1443 (Philadelphia Toboggan and Coaster Company) at North Penn Area 6 Superfund Site, Lansdale, Pennsylvania [gal/min, gallon per minute]

\begin{tabular}{|c|c|c|c|c|}
\hline $\begin{array}{c}\text { Depth } \\
\text { (feet below } \\
\text { land surface) }\end{array}$ & $\begin{array}{c}\text { Flow rate } \\
\text { (gal/min) } \\
\text { nonpumping } \\
\text { conditions }\end{array}$ & $\begin{array}{c}\text { Flow } \\
\text { direction } \\
\text { nonpumping } \\
\text { conditions }\end{array}$ & $\begin{array}{l}\text { Flow rate } \\
\text { (gal/min) } \\
\text { pumping } \\
\text { conditions }\end{array}$ & $\begin{array}{c}\text { Flow } \\
\text { direction } \\
\text { pumping } \\
\text { conditions }\end{array}$ \\
\hline 68 & 0.07 & up & 0.89 & up \\
\hline 90 & .07 & up & .82 & up \\
\hline 123.6 & no data & no data & .70 & up \\
\hline 124 & .10 & up & no data & no data \\
\hline 154 & .09 & up & .61 & up \\
\hline 200 & .13 & up & .60 & up \\
\hline 250 & .24 & up & .76 & up \\
\hline 275 & .20 & up & .63 & up \\
\hline 300 & no data & no data & .26 & up \\
\hline 320 & .19 & up & .24 & up \\
\hline 332 & .21 & up & .25 & up \\
\hline
\end{tabular}




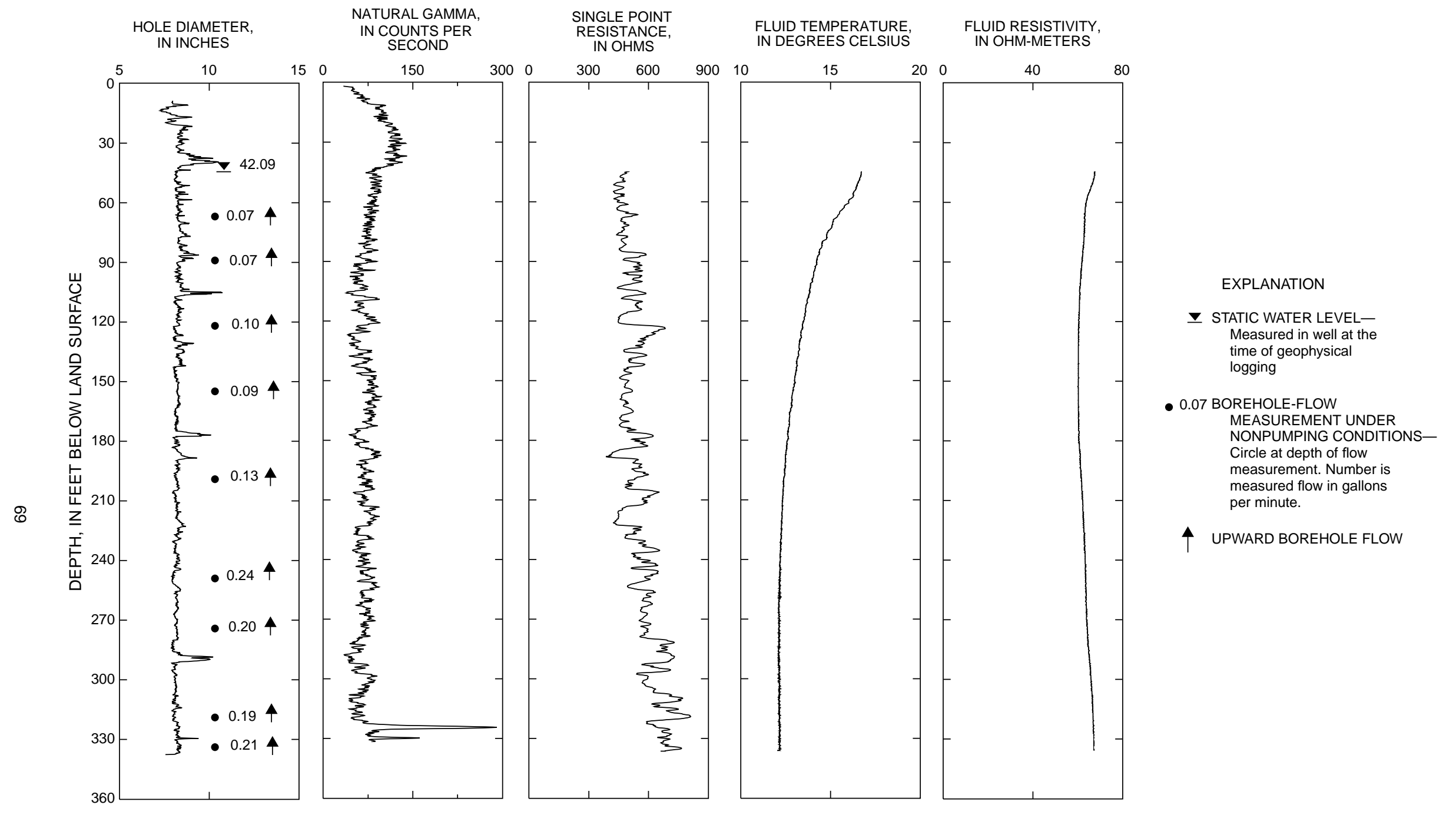

Figure 44. Borehole geophysical logs and direction of nonpumping flow within borehole MG-1443 (Philadelphia Toboggan and Coaster Company), North Penn Area 6 Superfund Site, Lansdale, Montgomery County, Pennsylvania. 


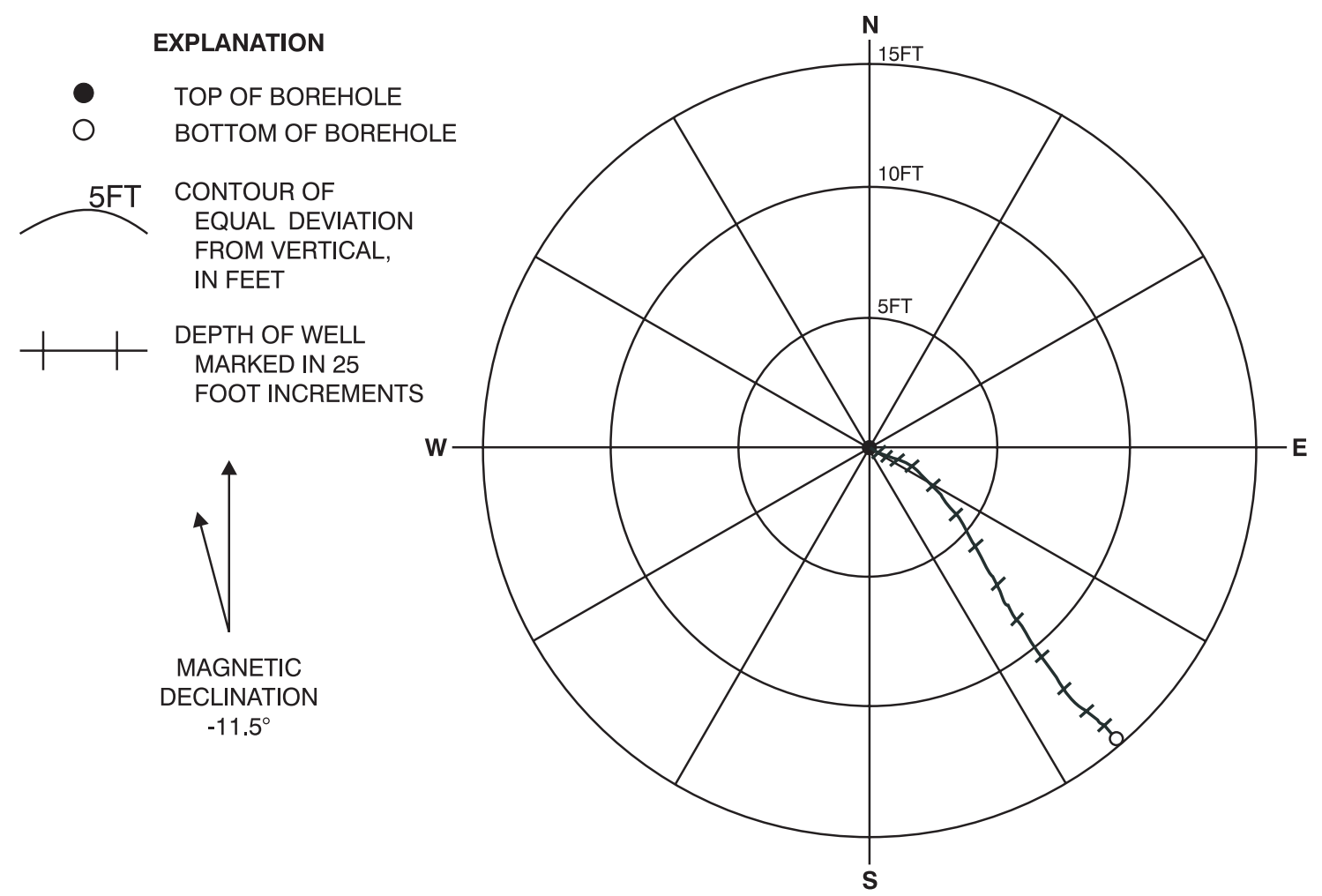

Figure 45. Magnitude and direction of deviation from vertical of borehole MG-1443 (Philadelphia Toboggan and Coaster Company).

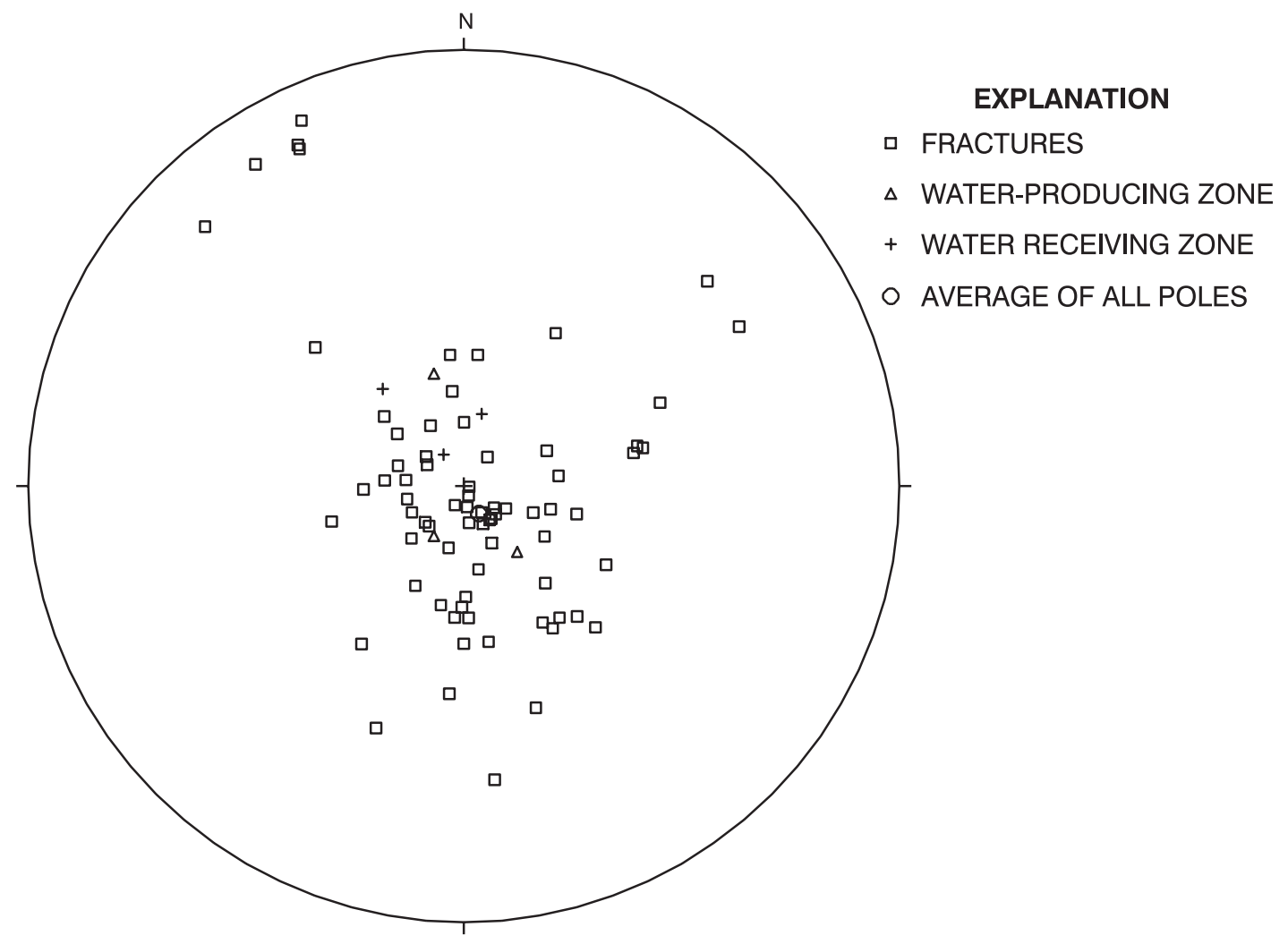

Figure 46. Equal-area lower hemisphere, stereographic projection of poles perpendicular to fracture planes in borehole MG-1443 (Philadelphia Toboggan and Coaster Company). 


\section{MG-1444 (Roger's Mechanical)}

The caliper log shows the total depth of the borehole is $294 \mathrm{ft}$ and it is cased with 6-in.-diameter casing to $17 \mathrm{ft}$ bls (fig. 47). The caliper log shows major fracture and fracture zones at 44-48, 70-72, 138-141, 153, 260-265 ft bls plus numerous other fractures throughout the borehole. The static water level at the time of logging was $49.75 \mathrm{ft}$ bls. The natural-gamma log shows shale units with elevated gamma readings at 115118 and 151-154 ft bls that might be used for stratigraphic correlation of geologic units with other wells. The fluid-resistivity $\log$ shows changes in slope at $60,273,279,285$, and $289 \mathrm{ft}$ bls that could be associated with water-producing zones. The fluid-temperature log shows changes in slope at 70 and $279 \mathrm{ft}$ bls that correlate to fractures shown on the caliper log. Under nonpumping conditions, the heatpulse flowmeter measured upward flow at $69,84,130,160,186,224,256$, and $270 \mathrm{ft}$ bls (table 26). Because of the high rate of nonpumping borehole flow, the well was not pumped and flowmetered. The suite of borehole geophysical logs and heatpulse-flowmeter measurements indicate water enters the borehole through fractures below $270 \mathrm{ft}$ bls and at 260-265 ft bls, moves upward, and generally exits the borehole through fractures at 70$73 \mathrm{ft}$ bls.

Table 26. Summary of heatpulse-flowmeter data for borehole MG-1444 (Roger's Mechanical) at North Penn Area 6 Superfund Site, Lansdale, Pennsylvania

[gal/min, gallon per minute]

\begin{tabular}{ccc}
\hline $\begin{array}{c}\text { Depth } \\
\text { (feet below } \\
\text { land surface) }\end{array}$ & $\begin{array}{c}\text { Flow rate } \\
\text { (gal/min) } \\
\text { nonpumping } \\
\text { conditions }\end{array}$ & $\begin{array}{c}\text { Flow direction } \\
\text { nonpumping } \\
\text { conditions }\end{array}$ \\
\hline 69 & 0.07 & up \\
84 & .96 & up \\
130 & 1.2 & up \\
160 & 1.0 & up \\
186 & .85 & up \\
224 & .94 & up \\
256 & 1.0 & up \\
270 & .22 & up \\
\hline
\end{tabular}



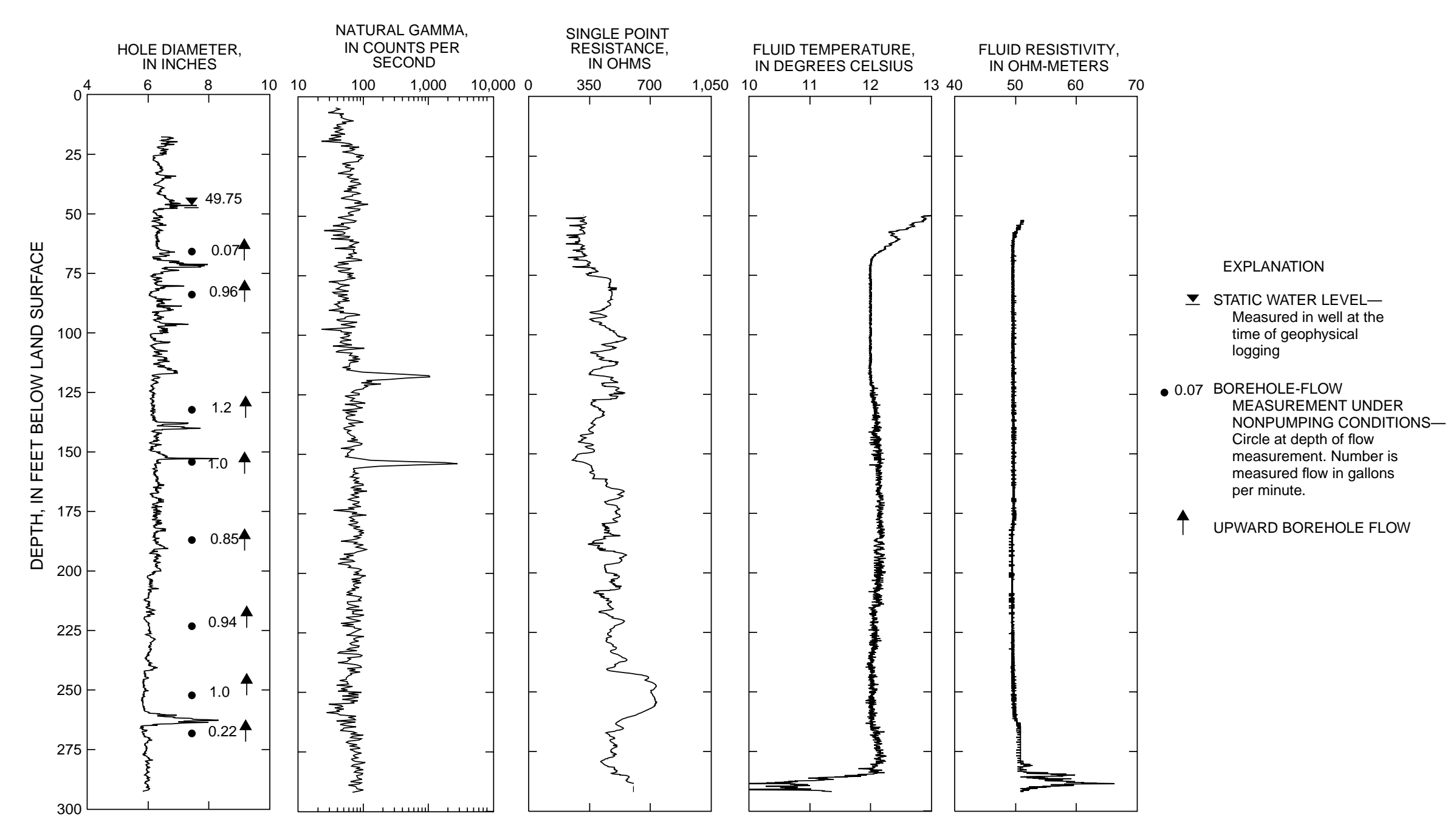

Figure 47. Borehole geophysical logs and direction of nonpumping flow within borehole MG-1444 (Roger's Mechanical), North Penn Area 6 Superfund Site, Lansdale, Montgomery County, Pennsylvania. 


\section{MG-1445 (American Olean Tile monitor well \#3)}

The caliper log shows the total depth of the borehole is $204 \mathrm{ft}$ and it is cased with 5-in.-diameter casing to $21 \mathrm{ft}$ bls (fig. 48). The caliper log shows a fracture at $21 \mathrm{ft}$ bls plus numerous other fractures throughout the borehole. The static water level at the time of logging was $40.09 \mathrm{ft}$ bls. The natural-gamma log shows a shale unit with an elevated gamma reading at 30-34 ft bls that might be used for stratigraphic correlation of geologic units with other wells. The fluid-temperature log shows a change in slope at approximately $90 \mathrm{ft}$ bls. Under nonpumping conditions, the heatpulse flowmeter measured downward flow at 98 and $130 \mathrm{ft}$ bls and no flow at 56, 80, 158, and $188 \mathrm{ft}$ bls (table 27). A submersible pump was placed at $65 \mathrm{ft}$ bls, and the well was pumped at approximately $0.75 \mathrm{gal} / \mathrm{min}$. The water level declined $4.15 \mathrm{ft}$ after $29 \mathrm{~min}$ of pumping before stabilizing. There is a slight discrepancy between the measured flow rate at $80 \mathrm{ft}$ bls and the pump discharge rate. This is because the water-level drawdown had not yet stabilized; part of the discharge was derived from borehole storage, causing the flow measurements to be less than the rate that would be produced from the aquifer alone. Under nonpumping conditions, the suite of borehole geophysical logs and heatpulse-flowmeter measurements indicate water enters the borehole through a fracture at $84 \mathrm{ft} \mathrm{bls,} \mathrm{moves} \mathrm{downward,} \mathrm{and} \mathrm{exits} \mathrm{the} \mathrm{borehole} \mathrm{through} \mathrm{fractures} \mathrm{at} \mathrm{110-120} \mathrm{and} \mathrm{130-}$ $150 \mathrm{ft}$ bls. Under pumping conditions, small quantities of water enter the borehole through fractures at 100$121,149,158-188$, and below $188 \mathrm{ft}$ bls. Possibly, additional water is contributed from fractures above $80 \mathrm{ft}$ bls that were not measured by the heatpulse flowmeter.

Table 27. Summary of heatpulse-flowmeter measurements for borehole MG-1445 (American Olean Tile monitor well \#3) at North Penn Area 6 Superfund Site, Lansdale, Pennsylvania

[gal/min, gallon per minute]

\begin{tabular}{ccccc}
\hline $\begin{array}{c}\text { Depth } \\
\text { (feet below } \\
\text { land surface) }\end{array}$ & $\begin{array}{c}\text { Flow rate } \\
\text { (gal/min) } \\
\text { nonpumping } \\
\text { conditions }\end{array}$ & $\begin{array}{c}\text { Flow } \\
\text { direction } \\
\text { nonpumping } \\
\text { conditions }\end{array}$ & $\begin{array}{c}\text { Flow rate } \\
\text { (gal/min) } \\
\text { pumping } \\
\text { conditions }\end{array}$ & $\begin{array}{c}\text { Flow } \\
\text { direction } \\
\text { pumping } \\
\text { conditions }\end{array}$ \\
\hline 56 & no flow & not determined & no data & no data \\
80 & no flow & not determined & 0.46 & up \\
98 & 0.2 & down & .47 & up \\
130 & .07 & down & .34 & up \\
158 & no flow & not determined & .21 & up \\
188 & no flow & not determined & .08 & up \\
\hline
\end{tabular}




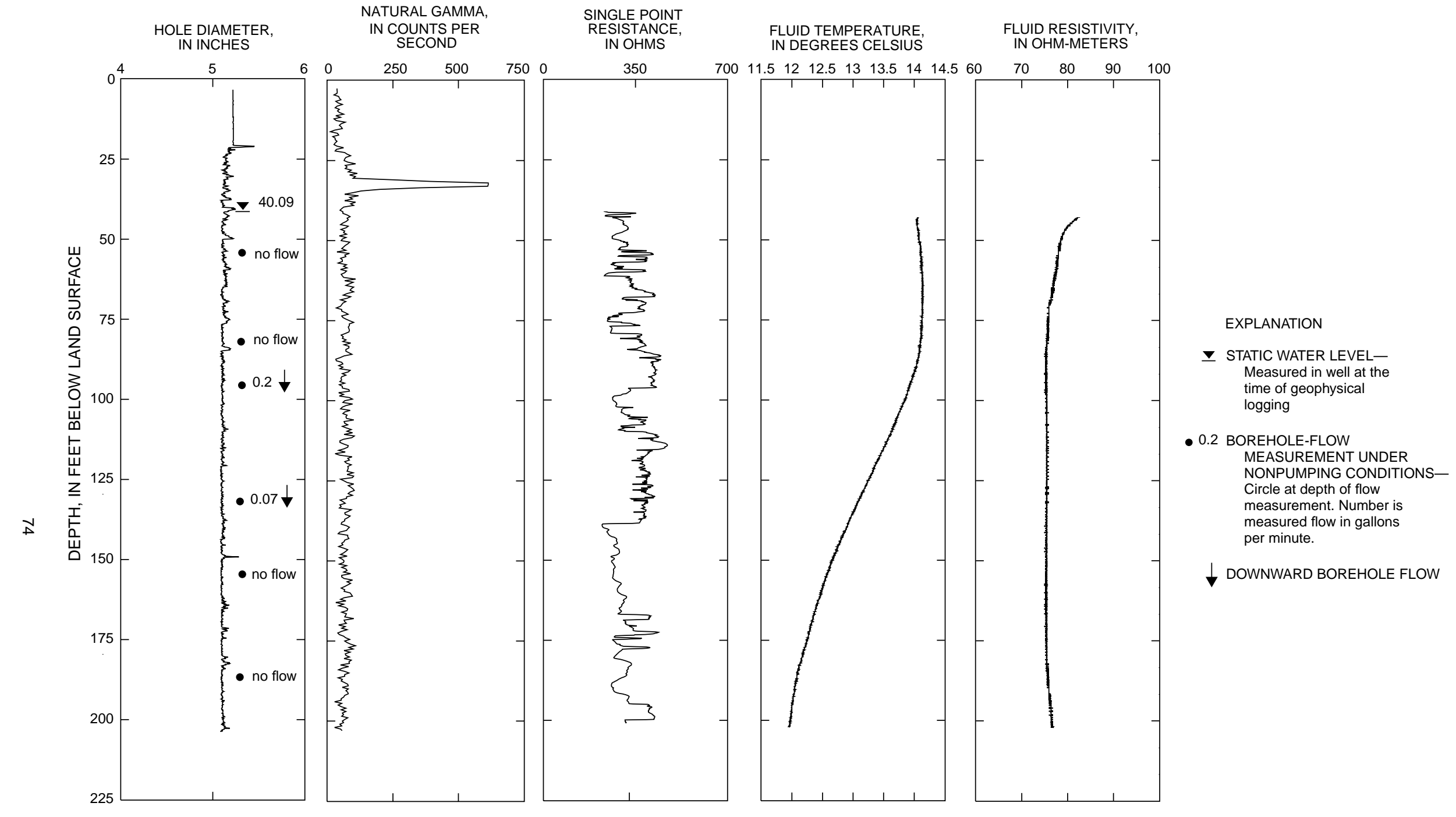

Figure 48. Borehole geophysical logs and direction of nonpumping flow within borehole MG-1445 (American Olean Tile monitor well \#3), North Penn Area 6 Superfund Site, Lansdale, Montgomery County, Pennsylvania. 


\section{MG-1446 (American Olean Tile monitor well \#1)}

The caliper log shows the total depth of the borehole is $144 \mathrm{ft}$ and it is cased with 6-in.-diameter casing to $19 \mathrm{ft}$ bls (fig. 49). The caliper log shows a fracture at 19-21 ft bls plus numerous minor fractures throughout the borehole. The static water level at the time of logging was $53.93 \mathrm{ft}$ bls. The fluid-resistivity $\log$ shows changes in slope at 74 and $122 \mathrm{ft}$ bls that correlate to fractures shown on the caliper log. Under nonpumping conditions, the heatpulse flowmeter measured upward flow at 68, 80, and $90 \mathrm{ft}$ bls, downward flow at $104 \mathrm{ft}$ bls, and no flow at $126 \mathrm{ft}$ bls (table 28). A submersible pump was placed at $60 \mathrm{ft}$ bls, and the well was pumped at approximately $1 \mathrm{gal} / \mathrm{min}$. The water level drawdown in the well was $0.85 \mathrm{ft}$ after $15 \mathrm{~min}$ of pumping before stabilizing. Under nonpumping conditions, the suite of borehole geophysical logs and heatpulse-flowmeter measurements indicate fluid enters the borehole through a fracture at 97-101 ft bls, moves downward, and exits the borehole through a fracture at $122 \mathrm{ft}$ bls. A lesser quantity of water produced from the fracture at $97-101 \mathrm{ft}$ bls moves upward, additional water is produced at 73-76 ft bls, and water exits the borehole through fractures at or above 55-59 ft bls. Under pumping conditions, the greatest quantity of water enters the borehole through the fracture at $122 \mathrm{ft}$ bls.

Table 28. Summary of heatpulse-flowmeter measurements for borehole MG-1446 (American Olean Tile monitor well \#1) at North Penn Area 6 Superfund Site, Lansdale, Pennsylvania [gal/min, gallon per minute]

\begin{tabular}{ccccc}
\hline $\begin{array}{c}\text { Depth } \\
\text { feet below } \\
\text { land surface) }\end{array}$ & $\begin{array}{c}\text { Flow rate } \\
\text { (gal/min) } \\
\text { nonpumping } \\
\text { conditions }\end{array}$ & $\begin{array}{c}\text { Flow } \\
\text { direction } \\
\text { nonpumping } \\
\text { conditions }\end{array}$ & $\begin{array}{c}\text { Flow rate } \\
\text { (gal/min) } \\
\text { pumping } \\
\text { conditions }\end{array}$ & $\begin{array}{c}\text { Flow } \\
\text { direction } \\
\text { pumping } \\
\text { conditions }\end{array}$ \\
\hline 68 & 0.13 & up & 1.2 & up \\
80 & .10 & up & 1.2 & up \\
90 & .06 & up & 1.2 & up \\
104 & .10 & down & 1.0 & up \\
126 & no flow & not determined & .09 & up \\
\hline
\end{tabular}




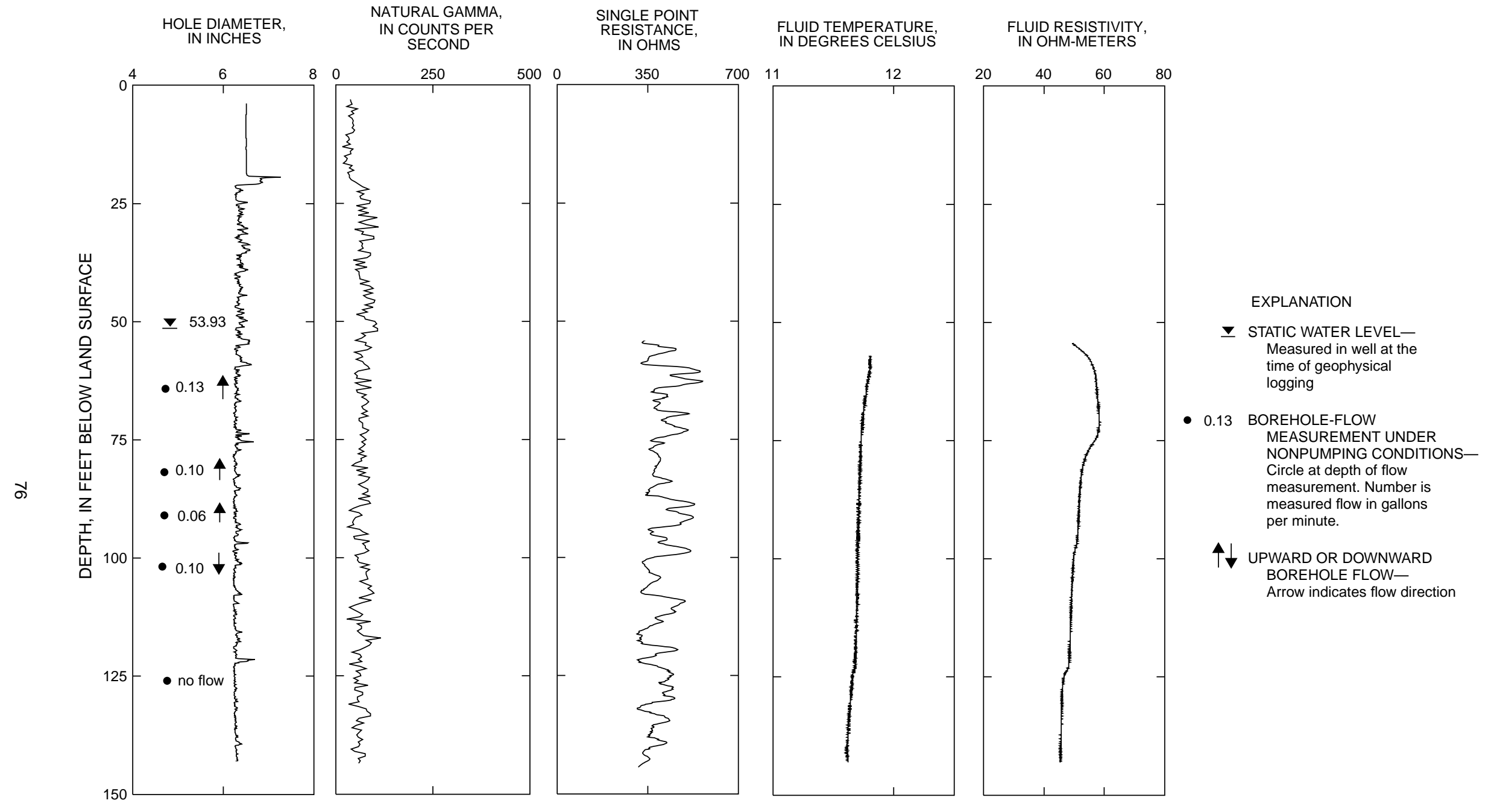

Figure 49. Borehole geophysical logs and direction of nonpumping flow within borehole MG-1446 (American Olean Tile monitor well \#1), North Penn Area 6 Superfund Site, Lansdale, Montgomery County, Pennsylvania. 


\section{MG-1447 (American Olean Tile monitor well \#2)}

The caliper log shows the total depth of the borehole is $145 \mathrm{ft}$ and it is cased with 6-in.-diameter casing to $19 \mathrm{ft}$ bls (fig. 50). The caliper log shows fractures at 19-21 and 127-130 ft bls plus other minor fractures throughout the borehole. The static water level in the well at the time of logging was $44.91 \mathrm{ft}$ bls. The fluidresistivity and fluid-temperature logs show changes in slope at 82 and $132 \mathrm{ft}$ bls. Under nonpumping conditions, the heatpulse flowmeter measured downward flow at 54, 74, 100, and $114 \mathrm{ft}$ bls and no flow at $134 \mathrm{ft} \mathrm{bls}$ (table 29). A submersible pump was placed at $60 \mathrm{ft} \mathrm{bls}$, and the well was pumped at approximately $0.5 \mathrm{gal} / \mathrm{min}$. The water level declined $0.3 \mathrm{ft}$ after $22 \mathrm{~min}$ of pumping before stabilizing. Under nonpumping conditions, the suite of borehole geophysical logs and heatpulse-flowmeter measurements indicate water enters the borehole through fractures at 48-50, 68-71, and $82 \mathrm{ft} \mathrm{bls,} \mathrm{moves} \mathrm{downward,} \mathrm{and} \mathrm{exits} \mathrm{the} \mathrm{borehole}$ through fractures at 104-108 and 127-130 ft bls. Under pumping conditions, the greatest quantity of water enters the borehole through the fracture at $127-130 \mathrm{ft}$ bls.

Table 29. Summary of heatpulse-flowmeter measurements for borehole MG-1447 (American Olean Tile monitor well \#2) at North Penn Area 6 Superfund Site, Lansdale, Pennsylvania [gal/min, gallon per minute]

\begin{tabular}{ccccc}
\hline $\begin{array}{c}\text { Depth } \\
\text { (feet below } \\
\text { land surface) }\end{array}$ & $\begin{array}{c}\text { Flow rate } \\
\text { (gal/min) } \\
\text { nonpumping } \\
\text { conditions }\end{array}$ & $\begin{array}{c}\text { Flow direction } \\
\text { nonpumping } \\
\text { conditions }\end{array}$ & $\begin{array}{c}\text { Flow rate } \\
\text { (gal/min) } \\
\text { pumping } \\
\text { conditions }\end{array}$ & $\begin{array}{c}\text { Flow direction } \\
\text { pumping } \\
\text { conditions }\end{array}$ \\
\hline 54 & 0.19 & down & no data & no data \\
74 & .29 & down & not calculated ${ }^{1}$ & not determined \\
100 & .36 & down & 1.0 & up \\
114 & .21 & down & 90 & up \\
134 & no flow & not determined & no flow & not determined \\
\hline
\end{tabular}

${ }^{1}$ Heatpulse flowmeter too close to pump for accurate measurement. 


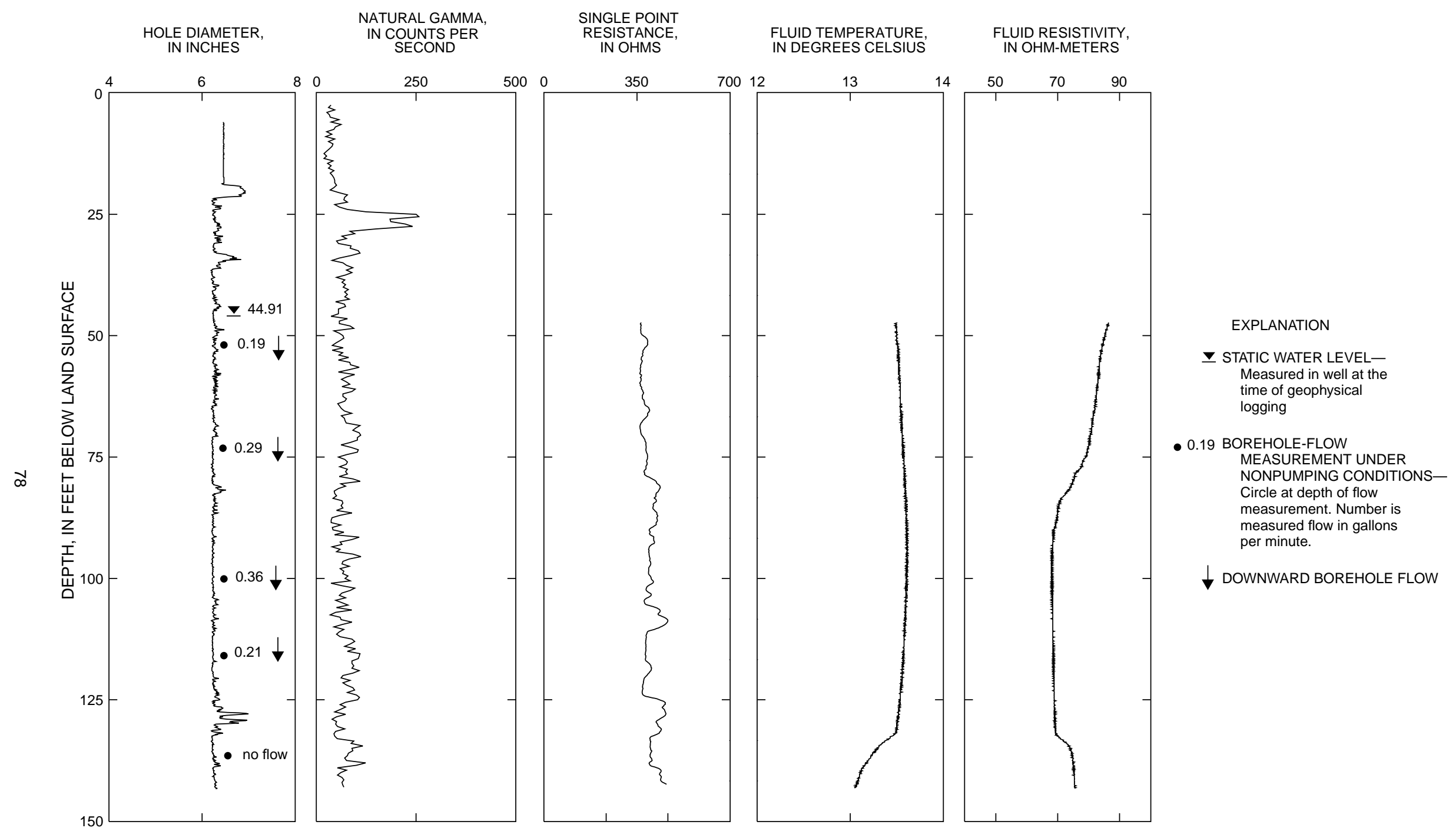

Figure 50. Borehole geophysical logs for borehole MG-1447 (American Olean Tile monitor well \#2), North Penn Area 6 Superfund Site, Lansdale, Montgomery County, Pennsylvania. 


\section{MG-1533 (E vans and Sons, Inc.)}

The caliper log shows the total depth of the borehole is $63 \mathrm{ft}$ and it is cased with 6-in.-diameter casing to $14 \mathrm{ft}$ bls (fig. 51). The caliper log shows major fractures at 18 and $24 \mathrm{ft}$ bls plus other minor fractures throughout the borehole. The static water level in the well at the time of logging was $47.16 \mathrm{ft}$ bls. The fluidresistivity log shows almost no gradient suggesting low to absent borehole flow. The borehole contained approximately only 14 feet of water and was not flowmetered.

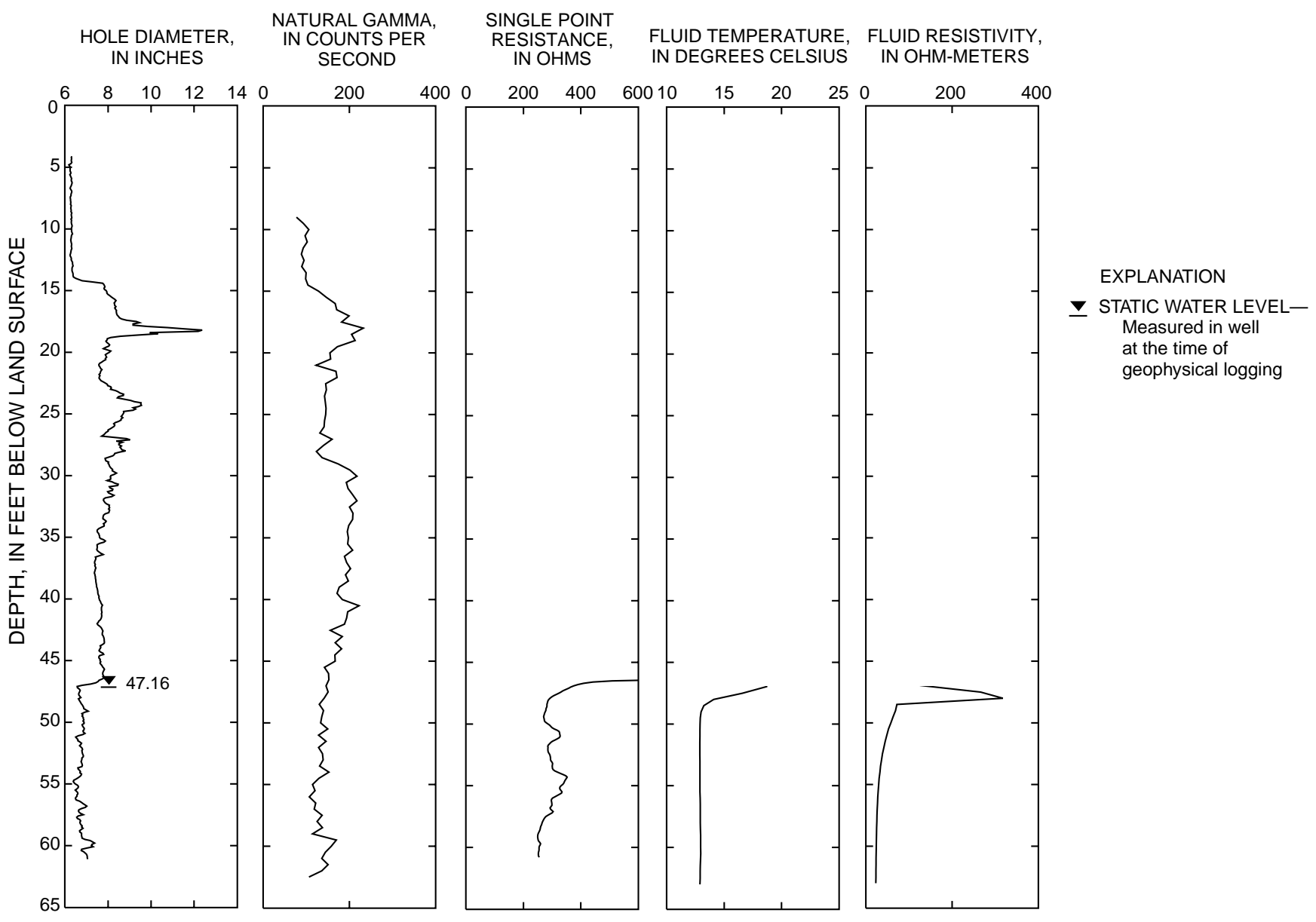

Figure 51. Borehole geophysical logs for borehole MG-1533 (Evans and Sons, Inc.), North Penn Area 6 Superfund Site, Lansdale, Montgomery County, Pennsylvania. 


\section{MG-1600 (R ogers 31)}

The caliper log shows the total depth of the borehole is $150 \mathrm{ft}$ and it is cased with 10-in.-diameter casing to $17 \mathrm{ft}$ bls (fig. 52). The caliper log shows major fractures at 17, 69, 88.5, and $91 \mathrm{ft}$ bls and minor fractures throughout the open-hole interval. The caliper log shows minor constrictions at 88 and $90 \mathrm{ft}$ bls. The static water level in the well at the time of logging was $48.83 \mathrm{ft}$ bls. The fluid-temperature log shows a change in slope at $64 \mathrm{ft}$ bls that correlates to fractures shown on the caliper log. Under nonpumping conditions, the heatpulse flowmeter measured upward borehole flow at 56, 74, 96, 112, 126, and $142 \mathrm{ft}$ bls (table 30). The geophysical logs and heatpulse-flowmeter measurements indicate water enters the borehole through fractures at 147-149 ft bls, moves upward, and exits the borehole through fractures at 96 and $74 \mathrm{ft}$ bls. A minor quantity of water exits the borehole at about $50 \mathrm{ft}$ bls. The driller's log reports a water-producing zone near $150 \mathrm{ft}$ bls.

Table 30. Summary of heatpulse-flowmeter measurements for borehole MG-1600 (Rogers 3I) at North Penn Area 6 Superfund Site, Lansdale, Montgomery County, Pennsylvania

[gal/min, gallon per minute]

\begin{tabular}{ccc}
\hline $\begin{array}{c}\text { Depth } \\
\text { (feet below } \\
\text { land surface) }\end{array}$ & $\begin{array}{c}\text { Flow rate } \\
\text { (gal/min) } \\
\text { nonpumping } \\
\text { conditions }\end{array}$ & $\begin{array}{c}\text { Flow } \\
\text { direction } \\
\text { nonpumping } \\
\text { conditions }\end{array}$ \\
\hline 56 & 0.11 & up \\
74 & .51 & up \\
96 & 1.1 & up \\
112 & 1.2 & up \\
126 & 1.2 & up \\
142 & 1.2 & up \\
\hline
\end{tabular}




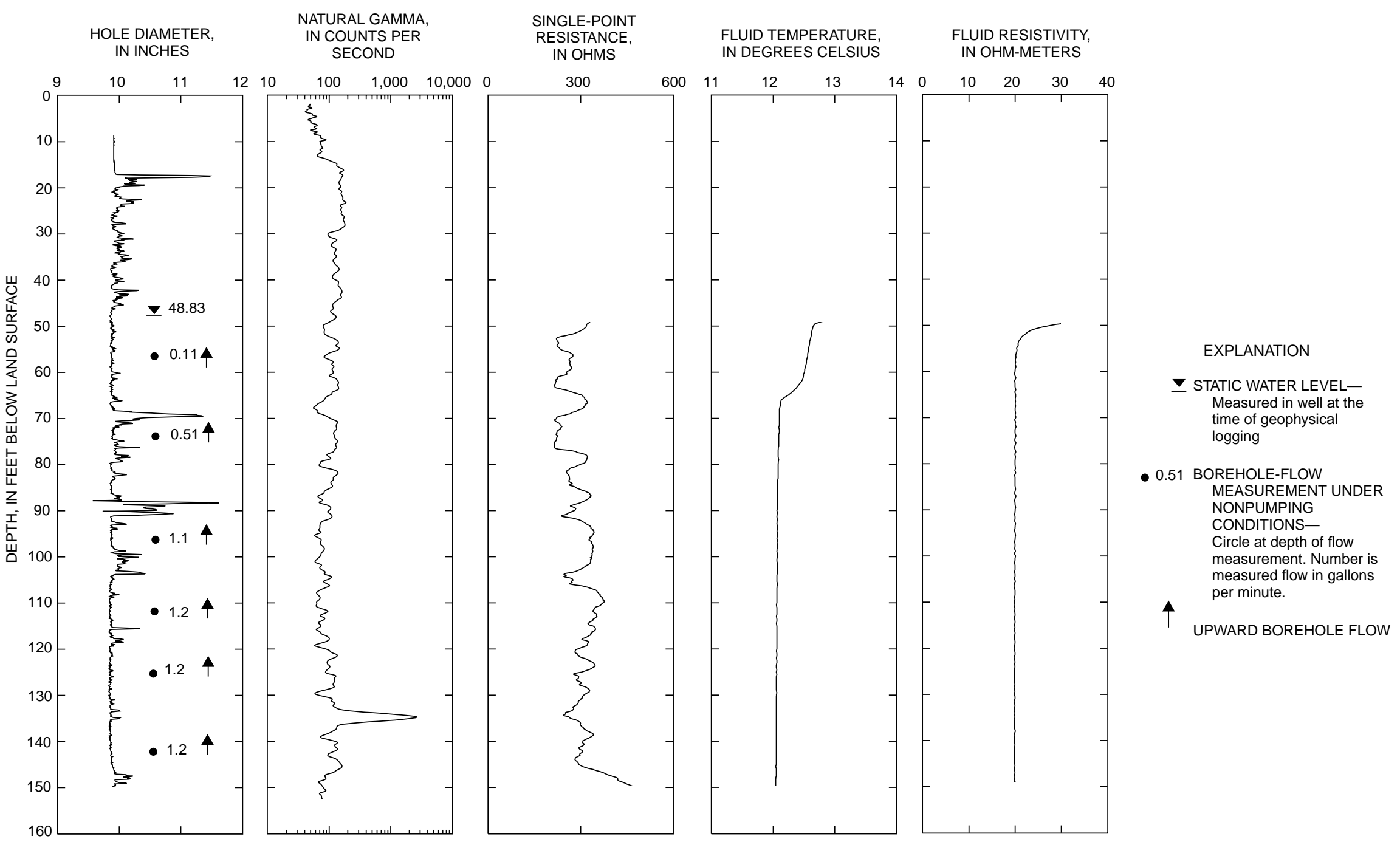

Figure 52. Borehole geophysical logs and direction of nonpumping flow within borehole MG-1600 (Rogers 3I), North Penn Area 6 Superfund Site, Lansdale, Montgomery County, Pennsylvania. 


\section{MG-1601 (Rogers 3S)}

The caliper log shows the total depth of the borehole is $100 \mathrm{ft}$ and it is cased with 6.25-in.-diameter casing to $13 \mathrm{ft}$ bls (fig. 53). The caliper log shows numerous minor fractures throughout the open-hole interval. The static water level in the well at the time of logging was $55.35 \mathrm{ft}$ bls. The fluid-resistivity log shows a consistent gradient with depth, indicating flow originates near the borehole bottom. The fluidtemperature log shows a consistent small decrease in temperature with depth. Under nonpumping conditions, the heatpulse flowmeter measured upward borehole flow at 80 and $92 \mathrm{ft}$ bls and no flow at $65 \mathrm{ft}$ bls (table 31). The geophysical logs and the heatpulse-flowmeter measurements indicate water enters the borehole through the fractures at 84-90 and 94-95 ft bls, moves upward, and exits the borehole at 66$77 \mathrm{ft}$ bls.

Table 31. Summary of heatpulse-flowmeter measurements for borehole MG-1601 (Rogers 3S) at North Penn Area 6 Superfund Site, Lansdale, Montgomery County, Pennsylvania

[gal/min, gallon per minute]

\begin{tabular}{ccc}
\hline $\begin{array}{c}\text { Depth } \\
\text { (feet below } \\
\text { land surface) }\end{array}$ & $\begin{array}{c}\text { Flow rate } \\
\text { (gal/min) } \\
\text { nonpumping } \\
\text { conditions }\end{array}$ & $\begin{array}{c}\text { Flow } \\
\text { direction } \\
\text { nonpumping } \\
\text { conditions }\end{array}$ \\
\hline 65 & no flow & not determined \\
80 & 0.36 & up \\
92 & .15 & up \\
\hline
\end{tabular}



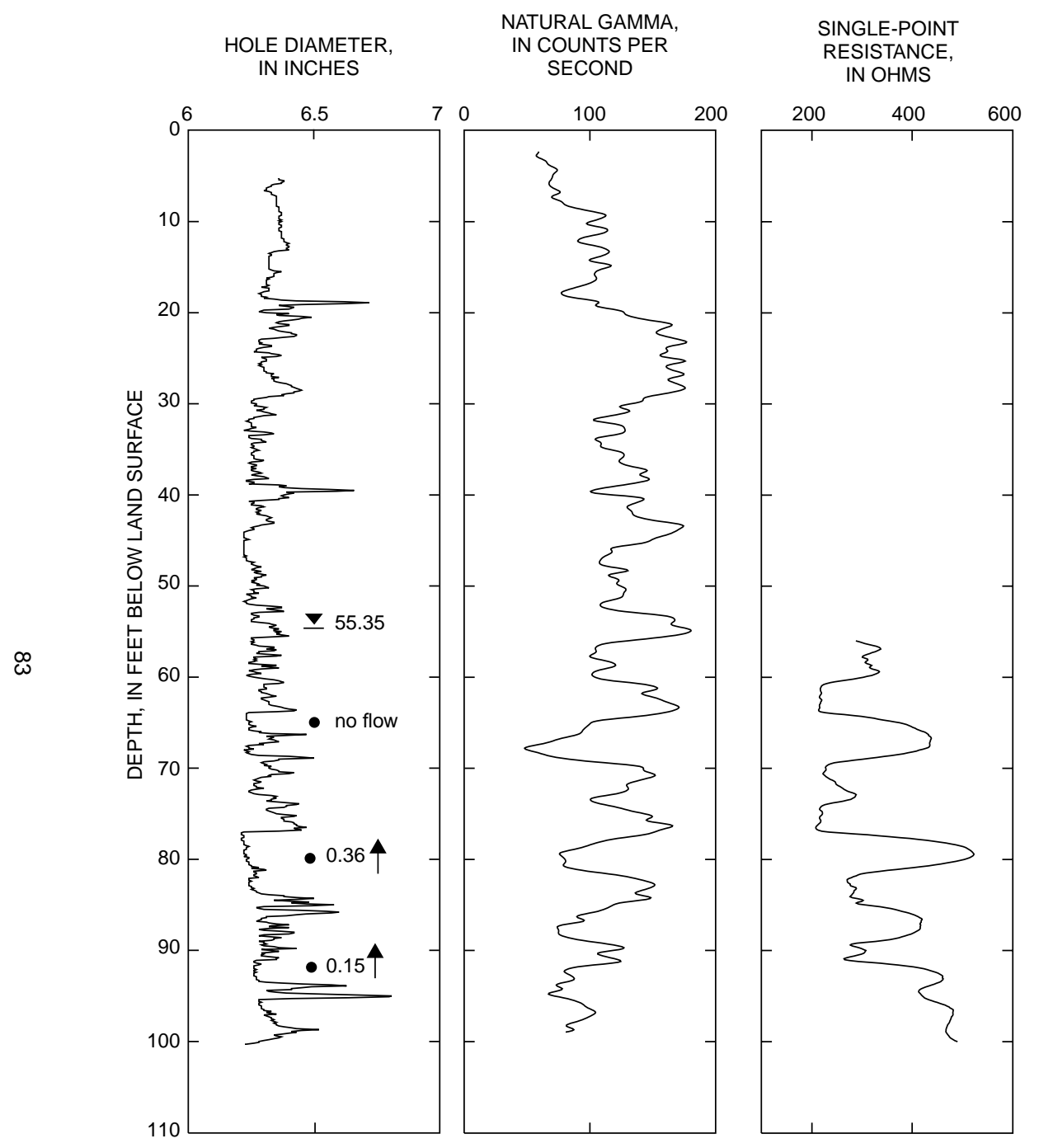

FLUID TEMPERATURE,
IN DEGREES CELSIUS
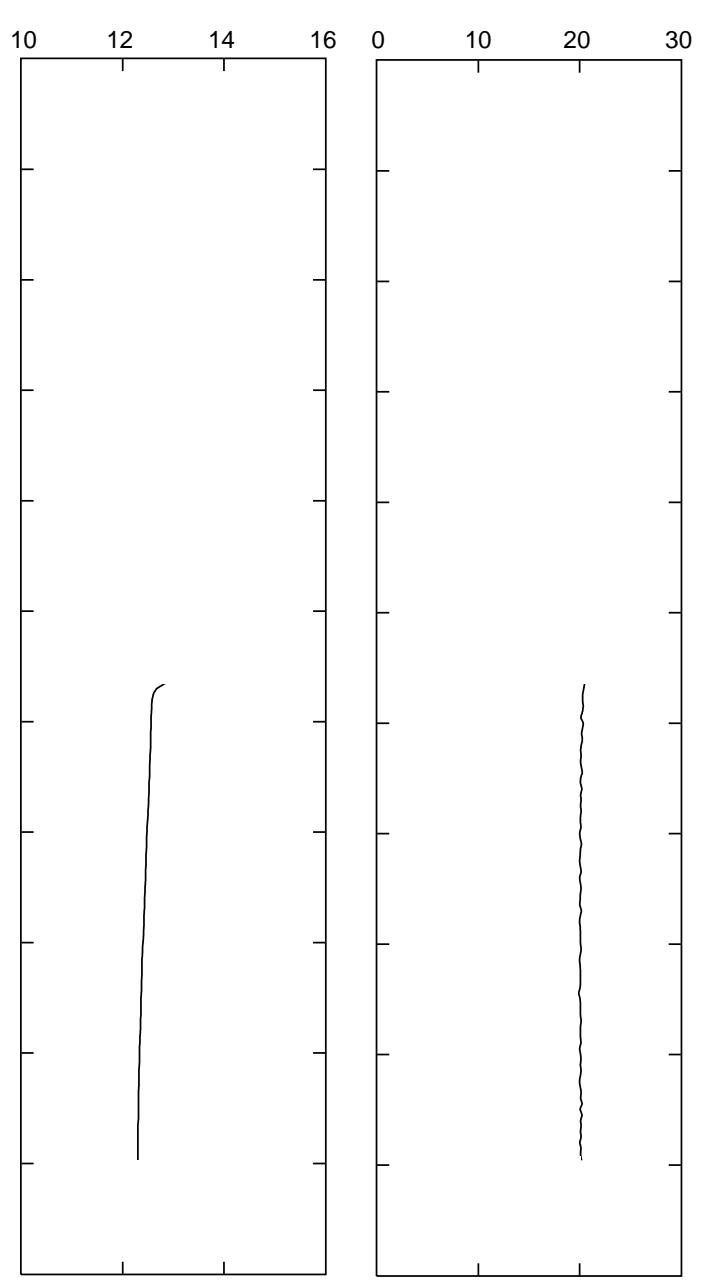

EXPLANATION

叉 STATIC WATER LEVELMeasured in well at the Measured in well at the
time of geophysical logging

- 0.36 BOREHOLE-FLOW MEASUREMENT UNDER NONPUMPING

Circle at depth of flow

measurement. Number is measured flow in gallons per minute.

个 UPWARD BOREHOLE FLOW

Figure 53. Borehole geophysical logs and direction of nonpumping flow within borehole MG-1601 (Rogers 3S), North Penn Area 6 Superfund Site, Lansdale, Montgomery County, Pennsylvania. 


\section{MG-1602 (Rogers 21 )}

The caliper log shows the total depth of the borehole is $131 \mathrm{ft}$ and it is cased with 10-in.-diameter casing to $14 \mathrm{ft}$ bls (fig. 54). The caliper log shows major fractures at 41-48, 69-72, and 76-79 ft bls and minor fractures throughout the open-hole interval. The static water level in the well at the time of logging was $55.10 \mathrm{ft}$ bls. The natural-gamma log shows shale units with elevated gamma readings at 91-94 and 127-130 ft bls. The fluid-resistivity log shows changes in slope at 72 and $118 \mathrm{ft}$ bls that correlate to fractures shown on the caliper log. Under nonpumping conditions, the heatpulse flowmeter measured upward borehole flow at 81, 105, and $123 \mathrm{ft}$ bls and no flow at $66 \mathrm{ft}$ bls (table 32). The geophysical logs and the heatpulse-flowmeter measurements indicate water enters the borehole through fractures at 115-116 and $129 \mathrm{ft}$ bls, moves upward, and exits the borehole through fractures at 69-79 $\mathrm{ft}$ bls.

Table 32. Summary of heatpulse-flowmeter measurements for borehole MG-1602 (Rogers 2I) at North Penn Area 6 Superfund Site, Lansdale, Montgomery County, Pennsylvania

[gal/min, gallon per minute]

\begin{tabular}{ccc}
\hline $\begin{array}{c}\text { Depth } \\
\text { feet below } \\
\text { land surface) }\end{array}$ & $\begin{array}{c}\text { Flow rate } \\
\text { (gal/min) } \\
\text { nonpumping } \\
\text { conditions }\end{array}$ & $\begin{array}{c}\text { Flow } \\
\text { direction } \\
\text { nonpumping } \\
\text { conditions }\end{array}$ \\
\hline 66 & no flow & not determined \\
81 & 0.96 & up \\
105 & .96 & up \\
123 & .12 & up \\
\hline
\end{tabular}



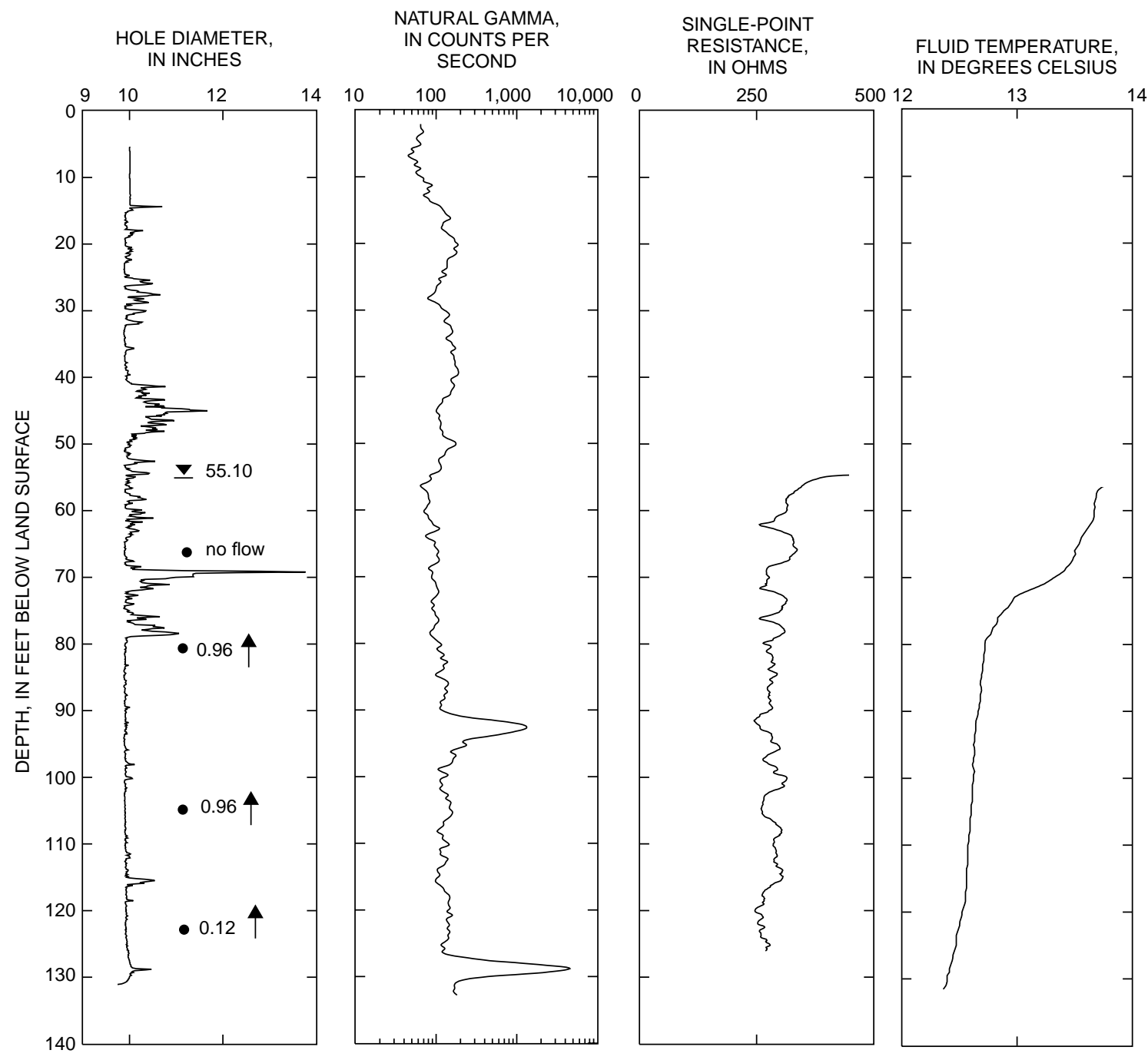

\section{FLUID RESISTIVITY,
IN OHM-METERS}

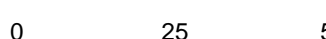

Figure 54. Borehole geophysical logs and direction of nonpumping flow within borehole MG-1602 (Rogers 2I), North Penn Area 6 Superfund Site, Lansdale, Montgomery County, Pennsylvania. 


\section{MG-1603 (Rogers 2S)}

The caliper log shows the total depth of the borehole is $98 \mathrm{ft}$ and it is cased with 6.25-in.-diameter casing to $14 \mathrm{ft}$ bls (fig. 55). The caliper log shows only minor fractures throughout the open-hole interval. The static water level at the time of logging was $64.67 \mathrm{ft}$ bls. The fluid-resistivity log shows almost no gradient and does not identify any water-producing zones. The fluid-temperature log shows a minor change in slope at about $80 \mathrm{ft}$ bls that may indicate a water-producing zone. Under nonpumping conditions, the heatpulse flowmeter measured downward borehole flow at $70 \mathrm{ft}$ bls and no flow at 76 and $86 \mathrm{ft}$ bls (table 33). The geophysical logs and the heatpulse-flowmeter measurements indicate water enters the borehole through fractures at about $65 \mathrm{ft}$ bls, moves downward, and exits the borehole through fractures at approximately $73 \mathrm{ft}$ bls.

Table 33. Summary of heatpulse-flowmeter measurements for borehole MG-1603 (Rogers 2S) at North Penn Area 6 Superfund Site, Lansdale, Montgomery County, Pennsylvania

[gal/min, gallon per minute]

\begin{tabular}{ccc}
\hline $\begin{array}{c}\text { Depth } \\
\text { (feet below } \\
\text { land surface) }\end{array}$ & $\begin{array}{c}\text { Flow rate } \\
\text { (gal/min) } \\
\text { nonpumping } \\
\text { conditions }\end{array}$ & $\begin{array}{c}\text { Flow direction } \\
\text { nonpumping } \\
\text { conditions }\end{array}$ \\
\hline 70 & 0.013 & down \\
76 & no flow & \\
86 & no flow & \\
\hline
\end{tabular}




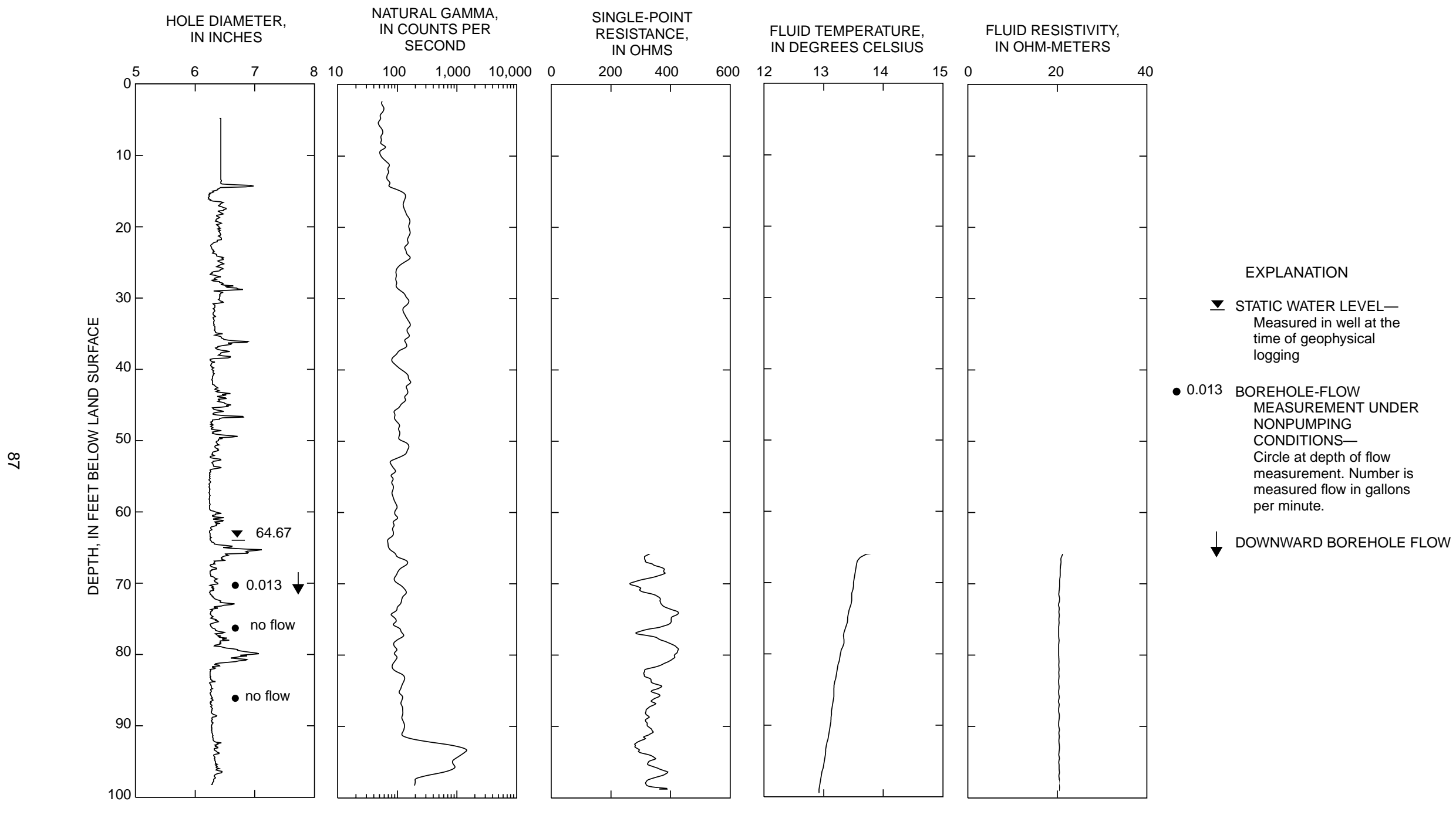

Figure 55. Borehole geophysical logs and direction of nonpumping flow within borehole MG-1603 (Rogers 2S), North Penn Area 6 Superfund Site, Lansdale, Montgomery County, Pennsylvania. 


\section{MG-1604 (Rogers 1D)}

The caliper log shows the total depth of the borehole is $221 \mathrm{ft}$ and it is cased with 10-in.-diameter casing to $14 \mathrm{ft}$ bls (fig. 56). The caliper log shows major fractures at 14-15 and 214-220 ft bls plus other minor fractures throughout the borehole. The static water level at the time of logging was $55.48 \mathrm{ft}$ bls. The fluidresistivity and fluid-temperature logs show changes in slope at 75,117, and $180 \mathrm{ft}$ bls that correlate to minor fractures shown on the caliper log. Under nonpumping conditions, the heatpulse flowmeter measured upward borehole flow at 66, 90, 120, and $170 \mathrm{ft}$ bls (table 34). The geophysical logs and the heatpulseflowmeter measurements indicate water enters the borehole through fractures at 214- $221 \mathrm{ft}$ bls, moves upward, and exits the borehole through fractures at 55-65 and 130-160 ft bls. A screen was placed at 212$222 \mathrm{ft}$ bls to include the water-producing fractures at 214-221 ft bls.

Table 34. Summary of heatpulse-flowmeter measurements for borehole MG-1604 (Rogers 1D) at North Penn Area 6 Superfund Site, Lansdale, Montgomery County, Pennsylvania

[gal/min, gallon per minute]

\begin{tabular}{ccc}
\hline $\begin{array}{c}\text { Depth } \\
\text { feet below } \\
\text { land surface) }\end{array}$ & $\begin{array}{c}\text { Flow rate } \\
\text { (gal/min) } \\
\text { nonpumping } \\
\text { conditions }\end{array}$ & $\begin{array}{c}\text { Flow direction } \\
\text { nonpumping } \\
\text { conditions }\end{array}$ \\
\hline 66 & 0.19 & up \\
90 & .16 & up \\
120 & .14 & up \\
170 & .21 & up \\
\hline
\end{tabular}




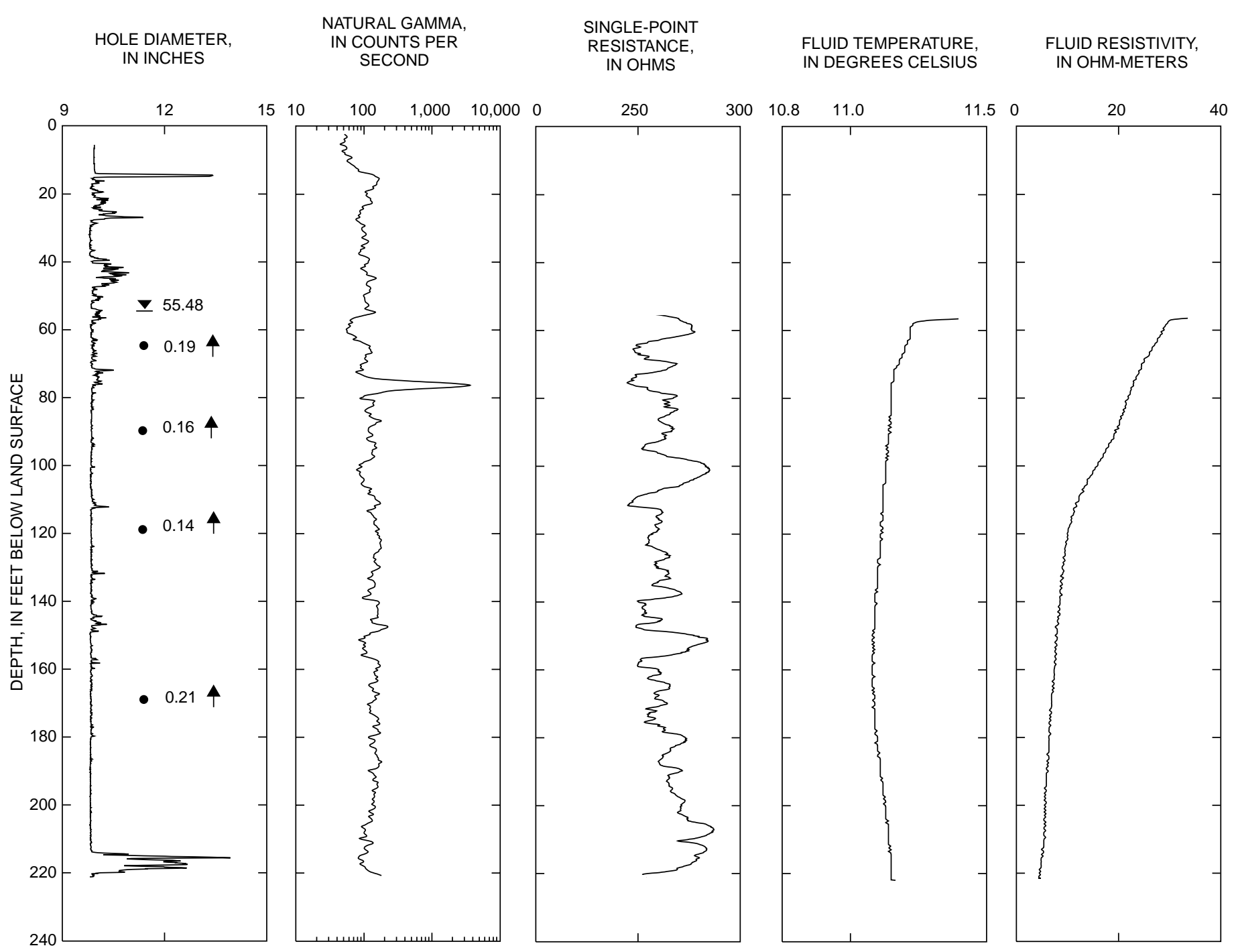

EXPLANATION

$\checkmark$ STATIC WATER LEVELMeasured in well at the time of geophysical logging

- 0.19 BOREHOLE-FLOW MEASUREMENT UNDER NONPUMPING

Circle at depth of flow

measurement. Number is

measured flow in gallons per minute.

$\uparrow$ UPWARD BOREHOLE FLOW

Figure 56. Borehole geophysical logs and direction of nonpumping flow within borehole MG-1604 (Rogers 1D), North Penn Area 6 Superfund Site, Lansdale, Montgomery County, Pennsylvania. 


\section{MG-1605 (Rogers 1S)}

The caliper log shows the total depth of the borehole is $95 \mathrm{ft}$ and it is cased with 6.25-in.-diameter casing to $15 \mathrm{ft}$ bls (fig. 57). The caliper log shows major fractures at 16 and $63 \mathrm{ft}$ bls plus numerous minor fractures throughout the open-hole interval. The static water level at the time of logging was $60.75 \mathrm{ft}$ bls. The fluid-resistivity $\log$ shows a sharp change in slope at $80 \mathrm{ft}$ bls that may indicate horizontal flow through the borehole. Under nonpumping conditions, the heatpulse flowmeter measured no borehole flow at 72.5, 81 , and $88 \mathrm{ft}$ bls (table 35). The geophysical logs and the heatpulse-flowmeter measurements indicate vertical flow is absent or less than detectable.

Table 35. Summary of heatpulse-flowmeter measurements for borehole MG-1605 (Rogers 1S) at North Penn Area 6 Superfund Site, Lansdale, Montgomery County, Pennsylvania

[gal/min, gallon per minute]

\begin{tabular}{ccc}
\hline $\begin{array}{c}\text { Depth } \\
\text { feet below } \\
\text { land surface) }\end{array}$ & $\begin{array}{c}\text { Flow rate } \\
\text { (gal/min) } \\
\text { nonpumping } \\
\text { conditions }\end{array}$ & $\begin{array}{c}\text { Flow direction } \\
\text { nonpumping } \\
\text { conditions }\end{array}$ \\
\hline 72.5 & no flow & not determined \\
81 & no flow & not determined \\
88 & no flow & not determined \\
\hline
\end{tabular}




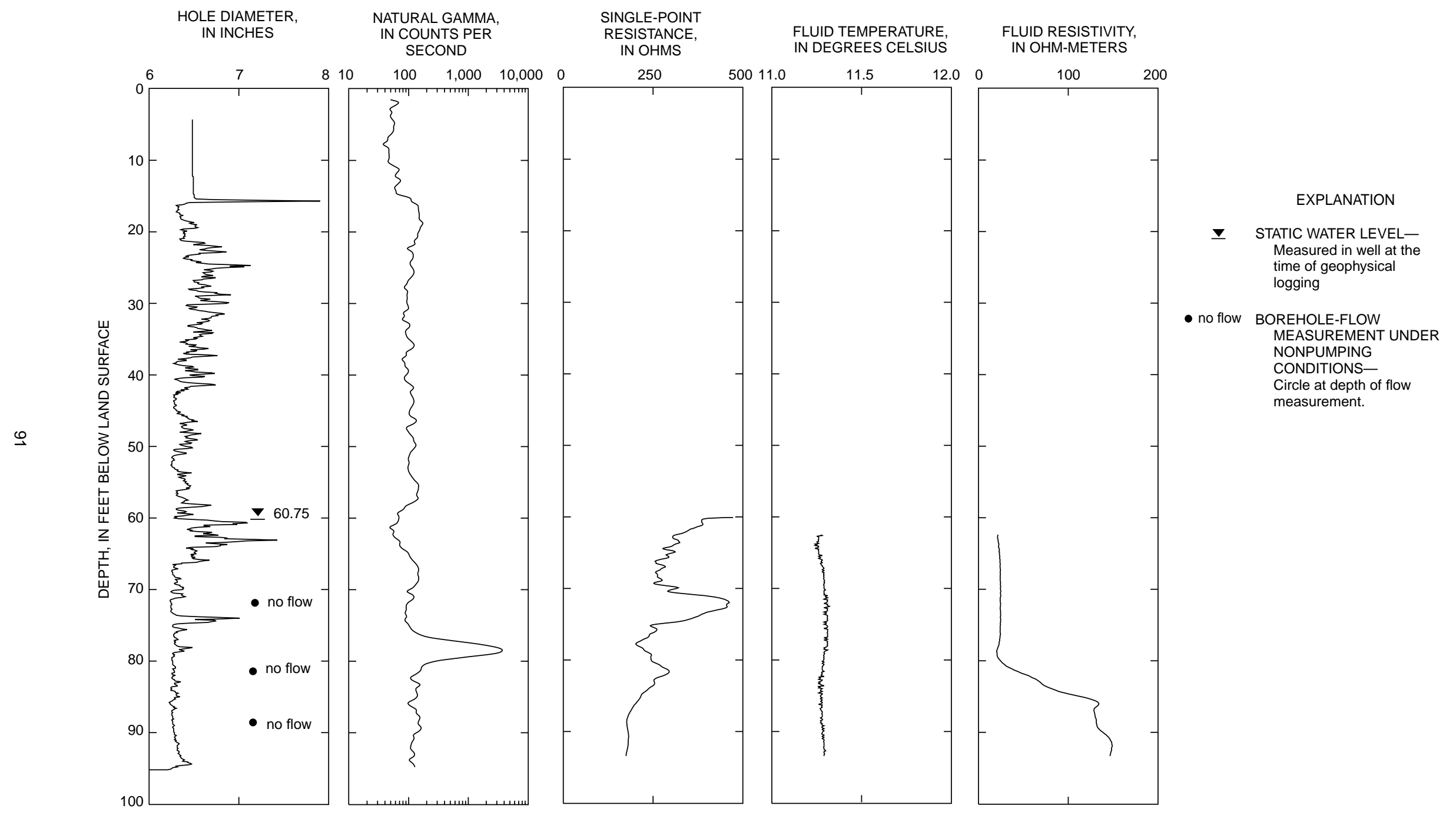

Figure 57. Borehole geophysical logs and direction of nonpumping flow within borehole MG-1605 (Rogers 1S), North Penn Area 6 Superfund Site, Lansdale, Montgomery County, Pennsylvania. 


\section{MG-1606 (Philadelphia Toboggan and Coaster Company 1S)}

The caliper log shows the total depth of the borehole is $101 \mathrm{ft}$ and it is cased with 6.25-in.-diameter casing to $15.5 \mathrm{ft}$ bls (fig. 58). The caliper log shows major fractures at 35 and $78 \mathrm{ft}$ bls plus minor fractures throughout the open-hole interval. The static water level at the time of logging was $43.12 \mathrm{ft}$ bls. The fluidresistivity log shows changes in slope at 50,60, and $88 \mathrm{ft}$ bls that correlate to minor fractures shown on the caliper log. Under nonpumping conditions, the heatpulse flowmeter measured upward borehole flow at $52,64,84$, and 94 bls (table 36). The geophysical logs and the heatpulse-flowmeter measurements indicate water enters the borehole through fractures at 55-61 and 94-100 ft bls, moves upward, and exits the borehole through fractures at $44-48 \mathrm{ft}$ bls.

Table 36. Summary of heatpulse-flowmeter measurements for borehole MG-1606 (Philadelphia Toboggan and Coaster Company 1S) at North Penn Area 6 Superfund Site, Lansdale, Montgomery County, Pennsylvania

[gal/min, gallon per minute]

\begin{tabular}{ccc}
\hline $\begin{array}{c}\text { Depth } \\
\text { feet below } \\
\text { land surface) }\end{array}$ & $\begin{array}{c}\text { Flow rate } \\
\text { (gal/min) } \\
\text { nonpumping } \\
\text { conditions }\end{array}$ & $\begin{array}{c}\text { Flow direction } \\
\text { nonpumping } \\
\text { conditions }\end{array}$ \\
\hline 52 & 0.14 & up \\
64 & .08 & up \\
84 & .08 & up \\
94 & .07 & up \\
\hline
\end{tabular}




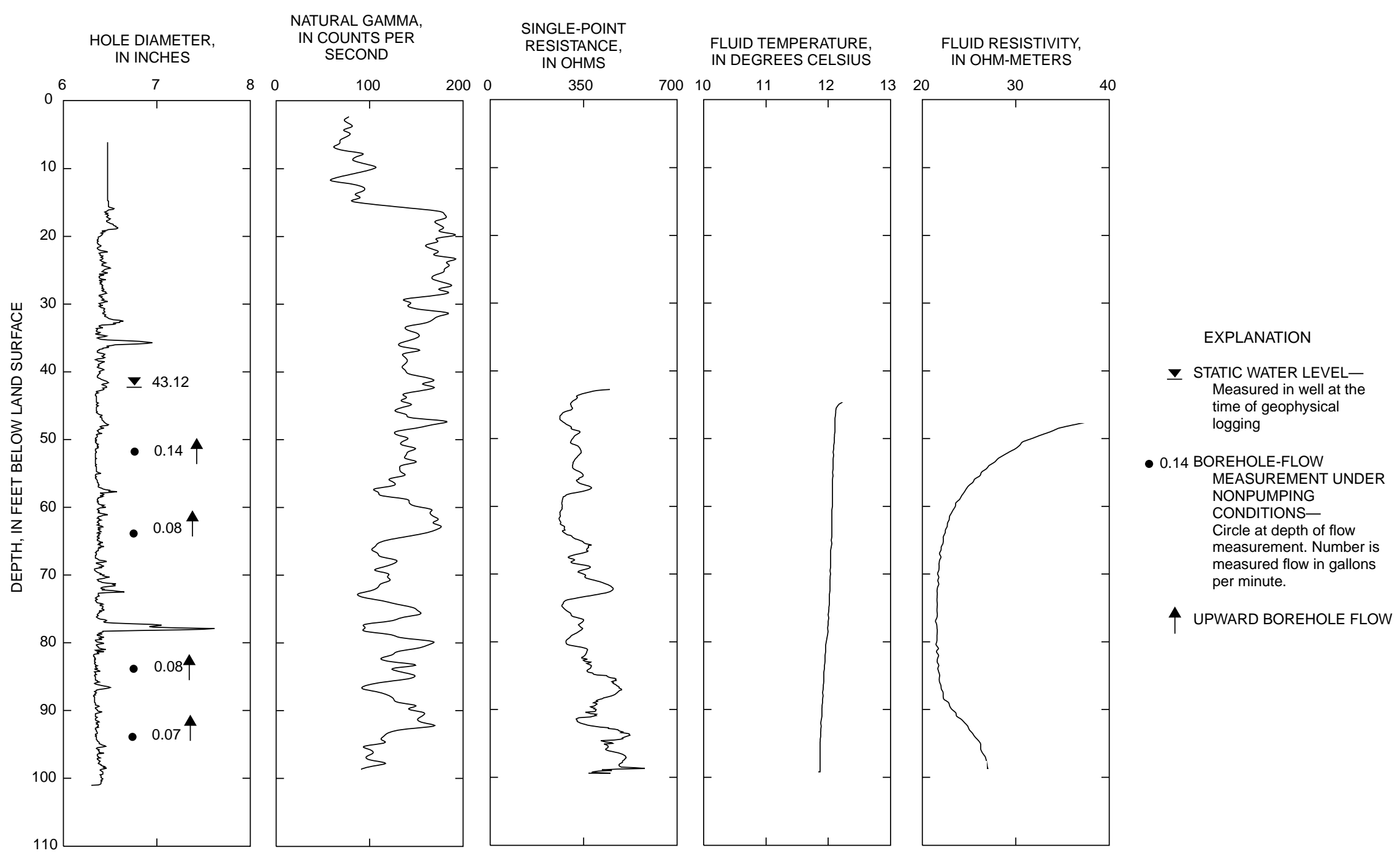

Figure 58. Borehole geophysical logs and direction of nonpumping flow within borehole MG-1606 (Philadelphia Toboggan and Coaster Company 1S), North Penn Area 6 Superfund Site, Lansdale, Montgomery County, Pennsylvania. 


\section{MG-1607 (Philadelphia Toboggan and Coaster Company 11)}

The caliper log shows the total depth of the borehole is $161 \mathrm{ft}$ and it is cased with 10-in.-diameter casing to $17.5 \mathrm{ft}$ bls (fig. 59). The caliper log shows major fractures at 73, 123, and 157-159 ft bls plus minor fractures throughout the open-hole interval. The static water level at the time of logging was $42.16 \mathrm{ft}$ bls. The fluidresistivity and fluid-temperature logs show a change in slope at $52 \mathrm{ft}$ bls. Under nonpumping conditions, the heatpulse flowmeter measured upward borehole flow at $64 \mathrm{ft}$ bls and downward flow at 104 and $140 \mathrm{ft}$ bls (table 37). The borehole video log shows the borehole water becomes cloudy at $45 \mathrm{ft}$ bls. The geophysical logs and the heatpulse-flowmeter measurements indicate water enters the borehole in the vicinity of the major fracture at $73 \mathrm{ft}$ bls, moves upward and downward, and exits the borehole through fractures at 52 and $157-159 \mathrm{ft}$ bls.

Table 37. Summary of heatpulse-flowmeter measurements for borehole MG-1607 (Philadelphia Toboggan and Coaster Company 1I) at North Penn Area 6 Superfund Site, Lansdale, Montgomery County, Pennsylvania

[gal/min, gallon per minute]

\begin{tabular}{ccc}
\hline $\begin{array}{c}\text { Depth } \\
\text { (feet below } \\
\text { land surface) }\end{array}$ & $\begin{array}{c}\text { Flow rate } \\
\text { (gal/min) } \\
\text { nonpumping } \\
\text { conditions }\end{array}$ & $\begin{array}{c}\text { Flow direction } \\
\text { nonpumping } \\
\text { conditions }\end{array}$ \\
\hline 64 & 0.15 & up \\
104 & .10 & down \\
140 & .10 & down \\
\hline
\end{tabular}




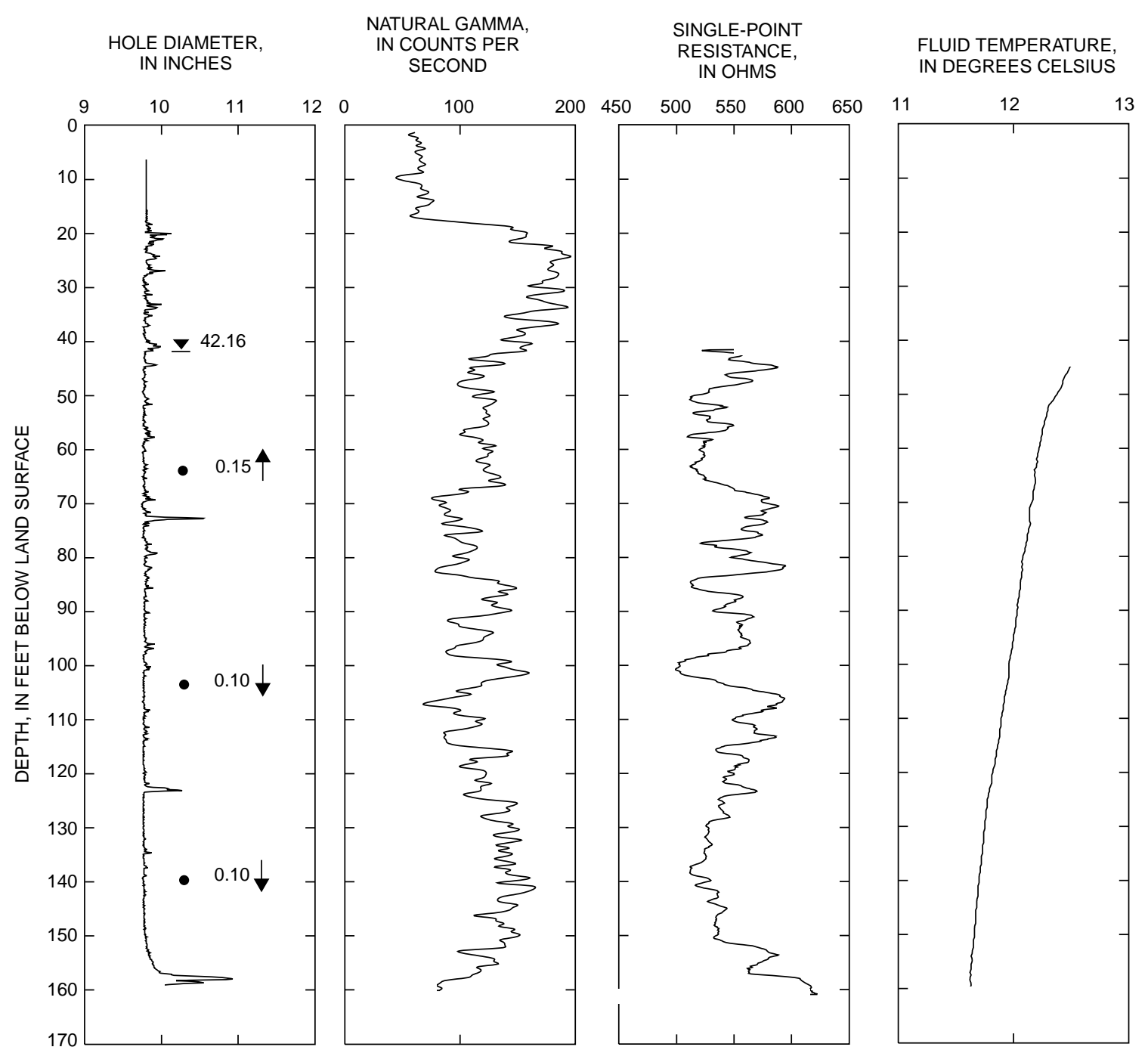

FLUID RESISTIVITY, IN OHM-METERS

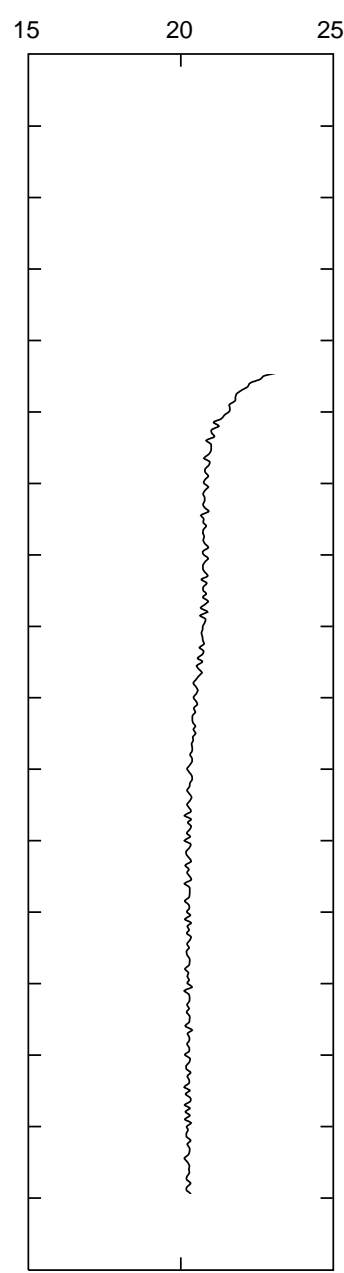

EXPLANATION

- STATIC WATER LEVELMeasured in well at the time of geophysical logging

- 0.15 BOREHOLE-FLOW MEASUREMENT UNDER NONPUMPING CONDITIONSCircle at depth of flow measurement. Number is measured flow in gallons per minute.

$\downarrow \downarrow$ UPWARD OR DOWNWARD BOREHOLE FLOWArrow indicates flow direction

Figure 59. Borehole geophysical logs and direction of nonpumping flow within borehole MG-1607 (Philadelphia Toboggan and Coaster Company 1I), North Penn Area 6 Superfund Site, Lansdale, Montgomery County, Pennsylvania. 


\section{MG-1608 (Philadelphia Toboggan and Coaster Company 1D)}

The caliper log shows the total depth of the borehole is $307 \mathrm{ft}$ and it is cased with 6.5-in.-diameter casing to $221 \mathrm{ft}$ bls (fig. 60). The caliper log shows major fractures at 221 and $276-282 \mathrm{ft}$ bls. The static water level at the time of logging was $39.67 \mathrm{ft}$ bls. The natural-gamma log shows shale units with elevated gamma readings at 300-302 and 305-307 ft bls that might be used for stratigraphic correlation of geologic units with other wells. The fluid-temperature log shows a change in slope at $224 \mathrm{ft}$ bls that is in proximity to the fracture shown at the bottom of casing on the caliper log and may be a water-producing zone. The change in the slope of the fluid-resistivity log at $234 \mathrm{ft}$ bls corresponds to a minor fracture shown on the caliper log. The driller's log reports water-producing zones at approximately 282 and $310 \mathrm{ft}$ bls that correlate to fractures on the caliper log. Under nonpumping conditions, the heatpulse flowmeter measured no borehole flow at 240, 263, and $288 \mathrm{ft}$ bls (table 38).

Table 38. Summary of heatpulse-flowmeter measurements for borehole MG-1608 (Philadelphia Toboggan and Coaster Company 1D) at North Penn Area 6 Superfund Site, Lansdale, Montgomery County, Pennsylvania

[gal/min, gallon per minute]

\begin{tabular}{ccc}
\hline $\begin{array}{c}\text { Depth } \\
\text { feet below } \\
\text { land surface) }\end{array}$ & $\begin{array}{c}\text { Flow rate } \\
\text { (gal/min) } \\
\text { nonpumping } \\
\text { conditions }\end{array}$ & $\begin{array}{c}\text { Flow direction } \\
\text { nonpumping } \\
\text { conditions }\end{array}$ \\
\hline 240 & no flow & not determined \\
263 & no flow & not determined \\
288 & no flow & not determined \\
\hline
\end{tabular}




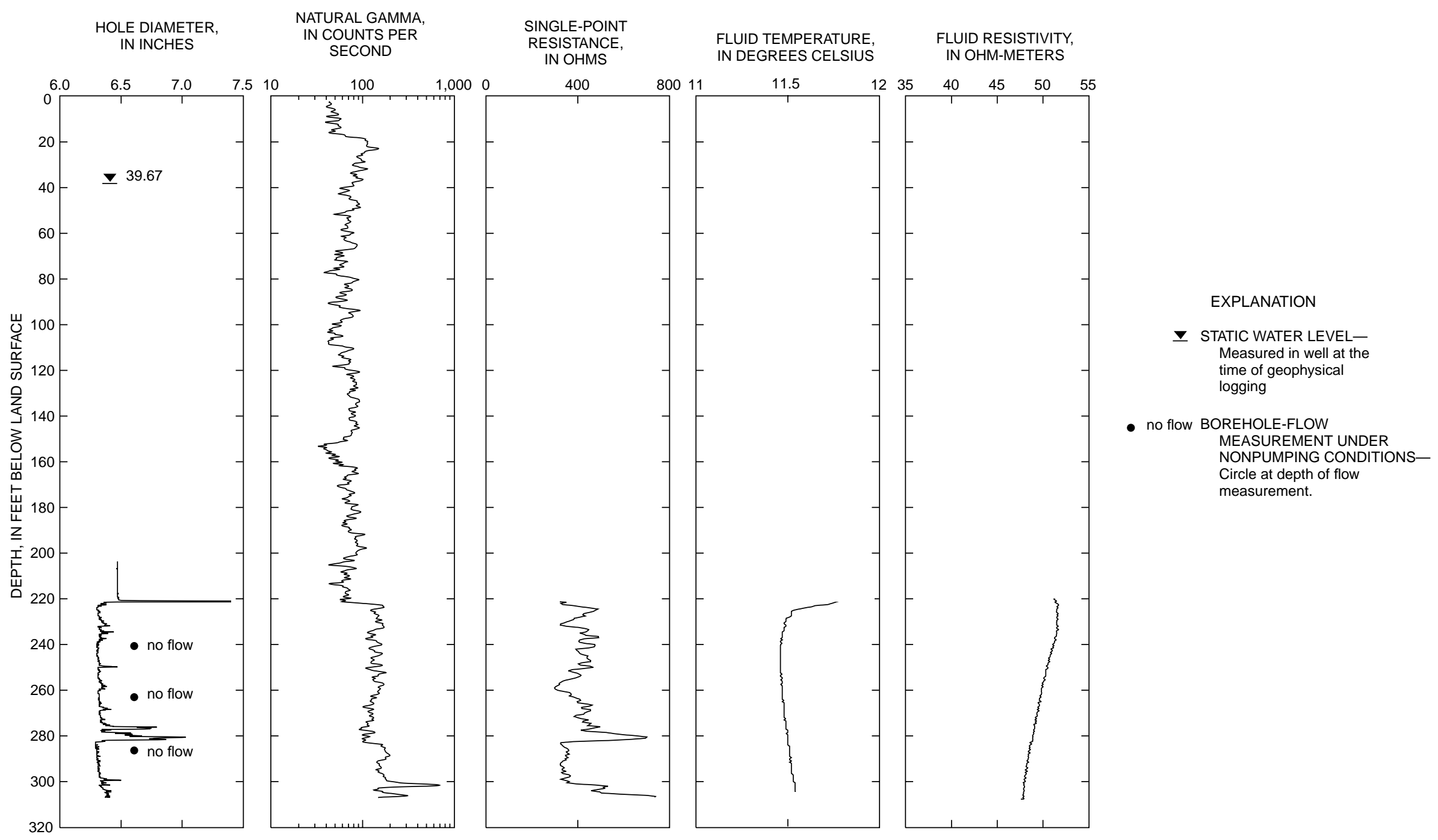

Figure 60. Borehole geophysical logs and direction of nonpumping flow within borehole MG-1608 (Philadelphia Toboggan and Coaster Company 1D), North Penn Area 6 Superfund Site, Lansdale, Montgomery County, Pennsylvania. 


\section{MG-1609 (Evans 2S)}

The caliper log shows the total depth of the borehole is $101 \mathrm{ft}$ and it is cased with 10-in.-diameter casing to $19 \mathrm{ft}$ bls (fig. 61). The caliper log shows major fractures at 30 and $79-81 \mathrm{ft}$ bls plus other minor fractures throughout the open-hole interval. The static water level at the time of logging was $46.45 \mathrm{ft}$ bls. The fluidresistivity log shows a change in slope at 50-60 ft bls, which is a water-producing zone. The fluidtemperature log shows a change in slope at $88 \mathrm{ft}$ bls that may be a water-producing zone. Under nonpumping conditions, the heatpulse flowmeter measured upward borehole flow at 52, 62, and $76 \mathrm{ft}$ bls and no flow at $86 \mathrm{ft}$ bls (table 39). The geophysical logs and the heatpulse-flowmeter measurements indicate water enters the borehole through the fracture at 79-81 ft bls, moves upward, and exits the borehole through fractures at approximately $48 \mathrm{ft}$ bls.

Table 39. Summary of heatpulse-flowmeter measurements for borehole MG-1609 (Evans 2S) at North Penn Area 6 Superfund Site, Lansdale, Montgomery County, Pennsylvania

[gal/min, gallon per minute]

\begin{tabular}{ccc}
\hline $\begin{array}{c}\text { Depth } \\
\text { (feet below } \\
\text { land surface) }\end{array}$ & $\begin{array}{c}\text { Flow rate } \\
\text { (gal/min) } \\
\text { nonpumping } \\
\text { conditions }\end{array}$ & $\begin{array}{c}\text { Flow direction } \\
\text { nonpumping } \\
\text { conditions }\end{array}$ \\
\hline 52 & 0.19 & up \\
62 & .10 & up \\
76 & .12 & up \\
86 & no flow & not determined \\
\hline
\end{tabular}




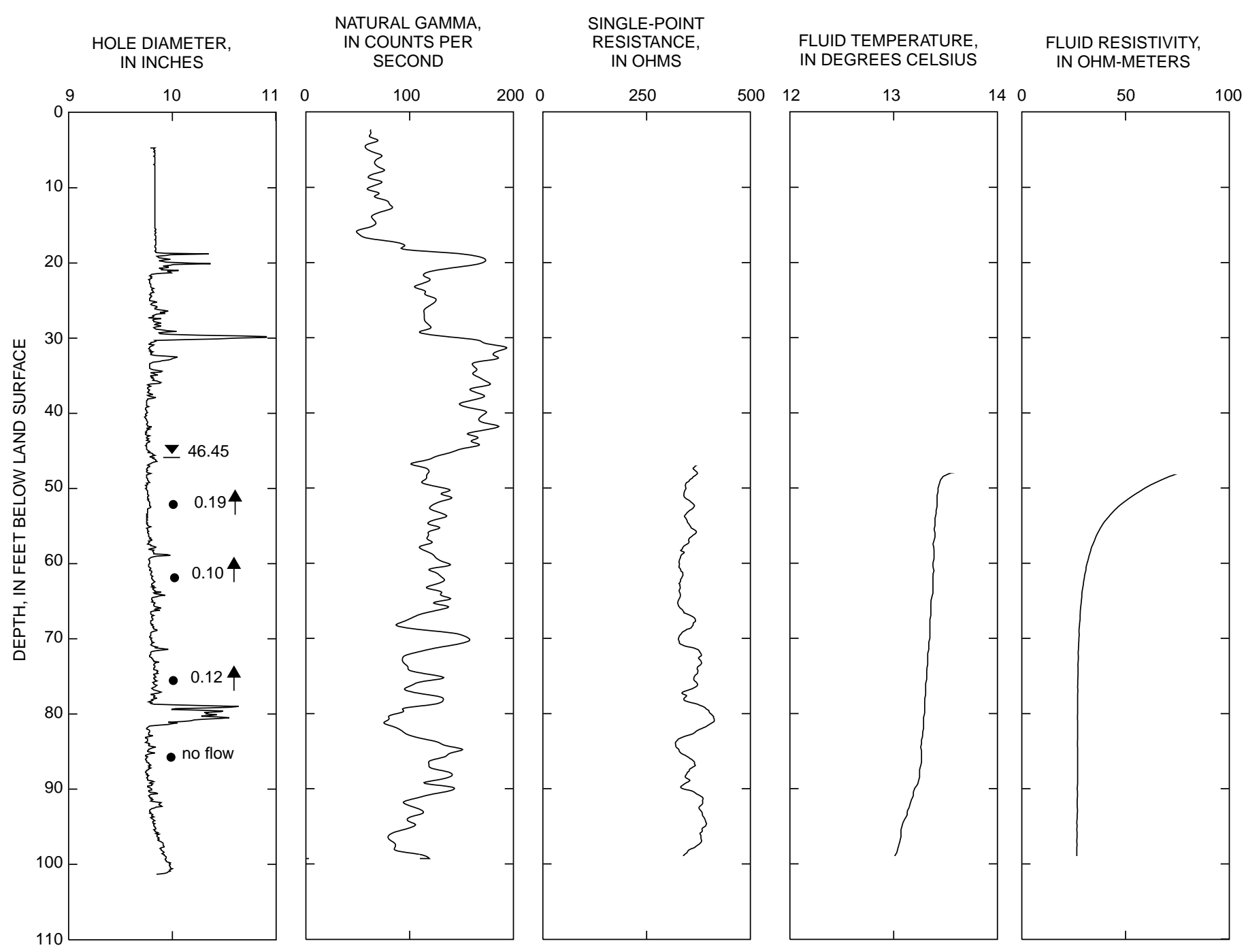

EXPLANATION

- STATIC WATER LEVELMeasured in well at the time of geophysical logging

0.19 BOREHOLE-FLOW

MEASUREMENT UNDER NONPUMPING CONDITIONSCircle at depth of flow measurement. Number is per minute. per minute.

个 UPWARD BOREHOLE FLOW

Figure 61. Borehole geophysical logs and direction of nonpumping flow within borehole MG-1609 (Evans 2S), North Penn Area 6 Superfund Site, Lansdale, Montgomery County, Pennsylvania. 


\section{MG-1610 (Keystone 1I)}

The caliper log shows the total depth of the borehole is $122 \mathrm{ft}$ and it is cased with 10-in.-diameter casing to $20 \mathrm{ft}$ bls (fig. 62). The caliper log shows major fractures at 20, 62, 105-108, and 120-121 ft bls plus numerous minor fractures throughout the open-hole interval. The static water level at the time of logging was $13.64 \mathrm{ft}$ bls. The fluid-resistivity $\log$ shows changes in slope at 20,32, 46, 58, and $96 \mathrm{ft}$ bls that indicate waterproducing zones. The fluid-temperature log shows changes in slope at 20,46, and $70 \mathrm{ft}$ bls that may be water-producing zones. Under nonpumping conditions, the heatpulse flowmeter measured upward borehole flow at $46 \mathrm{ft}$ bls and no flow at 28, 74, 98, and $110 \mathrm{ft}$ bls (table 40). The geophysical logs and the heatpulse-flowmeter measurements indicate water enters the borehole through fractures at $49 \mathrm{ft}$ bls, moves upward, and exits the borehole through fractures at 30-40 ft bls. The driller's log reports fractures at 105108 and $120-121 \mathrm{ft}$ bls produce a large quantity of water.

Table 40. Summary of heatpulse-flowmeter measurements for borehole MG-1610 (Keystone 1I) at North Penn Area 6 Superfund Site, Lansdale, Montgomery County, Pennsylvania

[gal/min, gallon per minute]

\begin{tabular}{ccc}
\hline $\begin{array}{c}\text { Depth } \\
\text { (feet below } \\
\text { land surface) }\end{array}$ & $\begin{array}{c}\text { Flow rate } \\
\text { (gal/min) } \\
\text { nonpumping } \\
\text { conditions }\end{array}$ & $\begin{array}{c}\text { Flow direction } \\
\text { nonpumping } \\
\text { conditions }\end{array}$ \\
\hline 28 & no flow & not determined \\
46 & 0.09 & up \\
74 & no flow & not determined \\
98 & no flow & not determined \\
110 & no flow & not determined \\
\hline
\end{tabular}




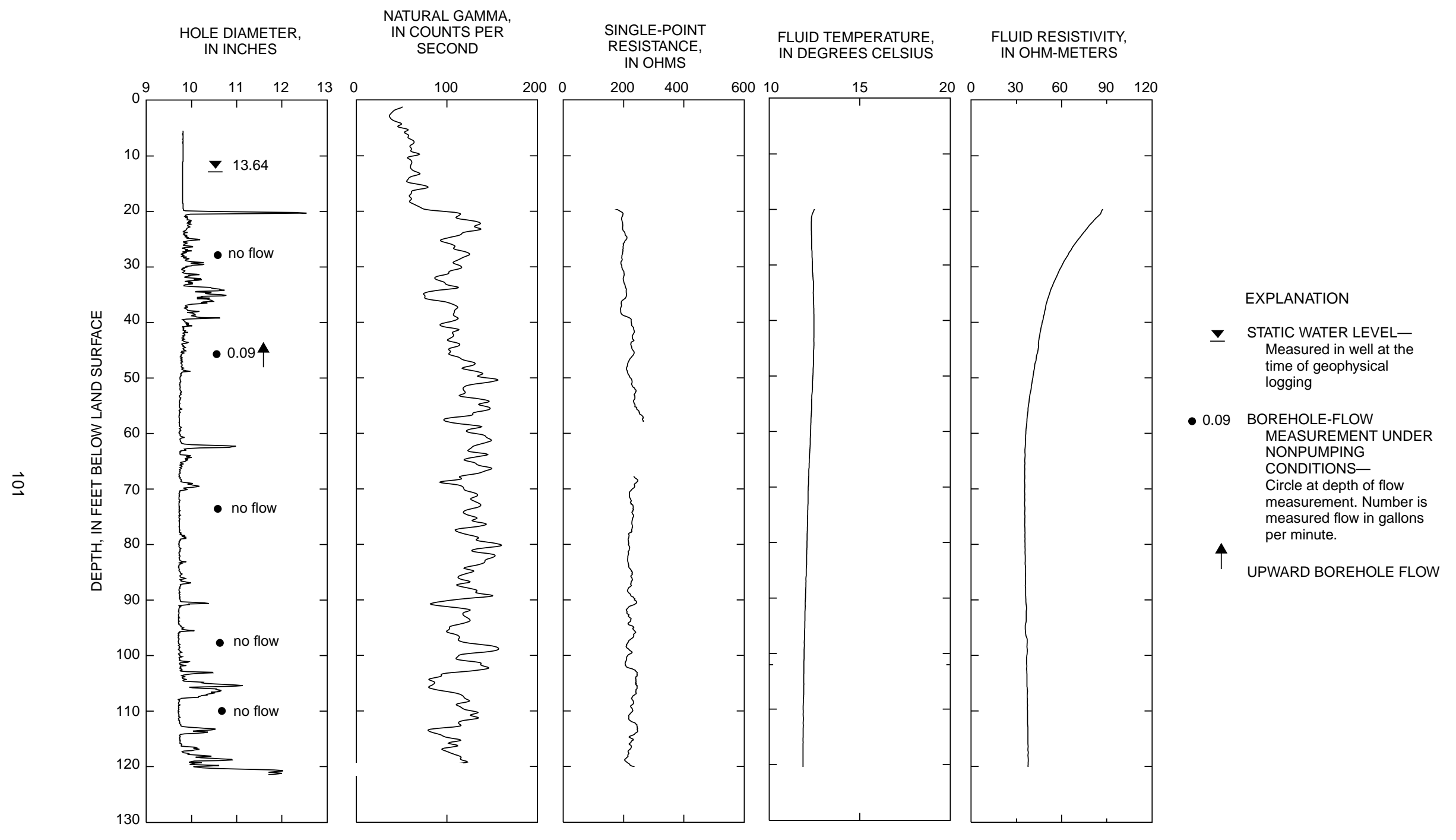

Figure 62. Borehole geophysical logs and direction of nonpumping flow within borehole MG-1610 (Keystone 1I), North Penn Area 6 Superfund Site, Lansdale, Montgomery County, Pennsylvania. 


\section{MG-1611 (Keystone 1S)}

The caliper log shows the total depth of the borehole is $88 \mathrm{ft}$ and it is cased with 6.5-in.-diameter casing to $15 \mathrm{ft}$ bls (fig. 63). The caliper log shows major fractures at 15, 32, and $35 \mathrm{ft}$ bls plus minor fractures throughout the open-hole interval. The static water level at the time of logging was $13.54 \mathrm{ft}$ bls. The dipmeter log shows the borehole deviates from vertical approximately $1.5 \mathrm{ft}$ to the south over the total length of the borehole (fig. 64).

The strike and dip of fracture planes was obtained from the acoustic televiewer. The results are shown on an equal-area stereonet with single points (poles) plotted in the lower hemisphere at right angles to the fracture planes. These poles indicate fracture planes trend northeast-southwest and northwest-southeast (fig. 65). Five possible bedding planes were identified. Two bedding planes dip to the northwest with an average strike and dip of N. $62^{\circ} \mathrm{E} ., 5^{\circ} \mathrm{NW}$. and are nearly coincident with regional strike and dip. Three bedding planes dip to the southeast with an average strike and dip of N. $39^{\circ}$ E., $5^{\circ}$ SE. Three high-angle fracture planes were identified. A plane representative of the average of these three fractures would have a strike and dip of N. $43^{\circ}$ W., $72^{\circ} \mathrm{NE}$.

The fluid-resistivity log shows changes in slope at 26 and $58 \mathrm{ft}$ bls that may indicate nearby waterproducing zones. The fluid-temperature log shows changes in slope at 26,40 , and $48 \mathrm{ft}$ bls that may indicate water-producing zones. The driller's log reported a water-producing zone at $63 \mathrm{ft}$ bls. Under nonpumping conditions, the heatpulse flowmeter measured no borehole flow at 24, 40, 60, and $74 \mathrm{ft}$ bls (table 41).

Table 41. Summary of heatpulse-flowmeter measurements for borehole MG-1611 (Keystone 1S) at North Penn Area 6 Superfund Site, Lansdale, Montgomery County, Pennsylvania

[gal/min, gallon per minute]

\begin{tabular}{ccc}
\hline $\begin{array}{c}\text { Depth } \\
\text { (feet below } \\
\text { land surface) }\end{array}$ & $\begin{array}{c}\text { Flow rate } \\
\text { (gal/min) } \\
\text { nonpumping } \\
\text { conditions }\end{array}$ & $\begin{array}{c}\text { Flow direction } \\
\text { nonpumping } \\
\text { conditions }\end{array}$ \\
\hline 24 & no flow & not determined \\
40 & no flow & not determined \\
60 & no flow & not determined \\
74 & no flow & not determined \\
\hline
\end{tabular}




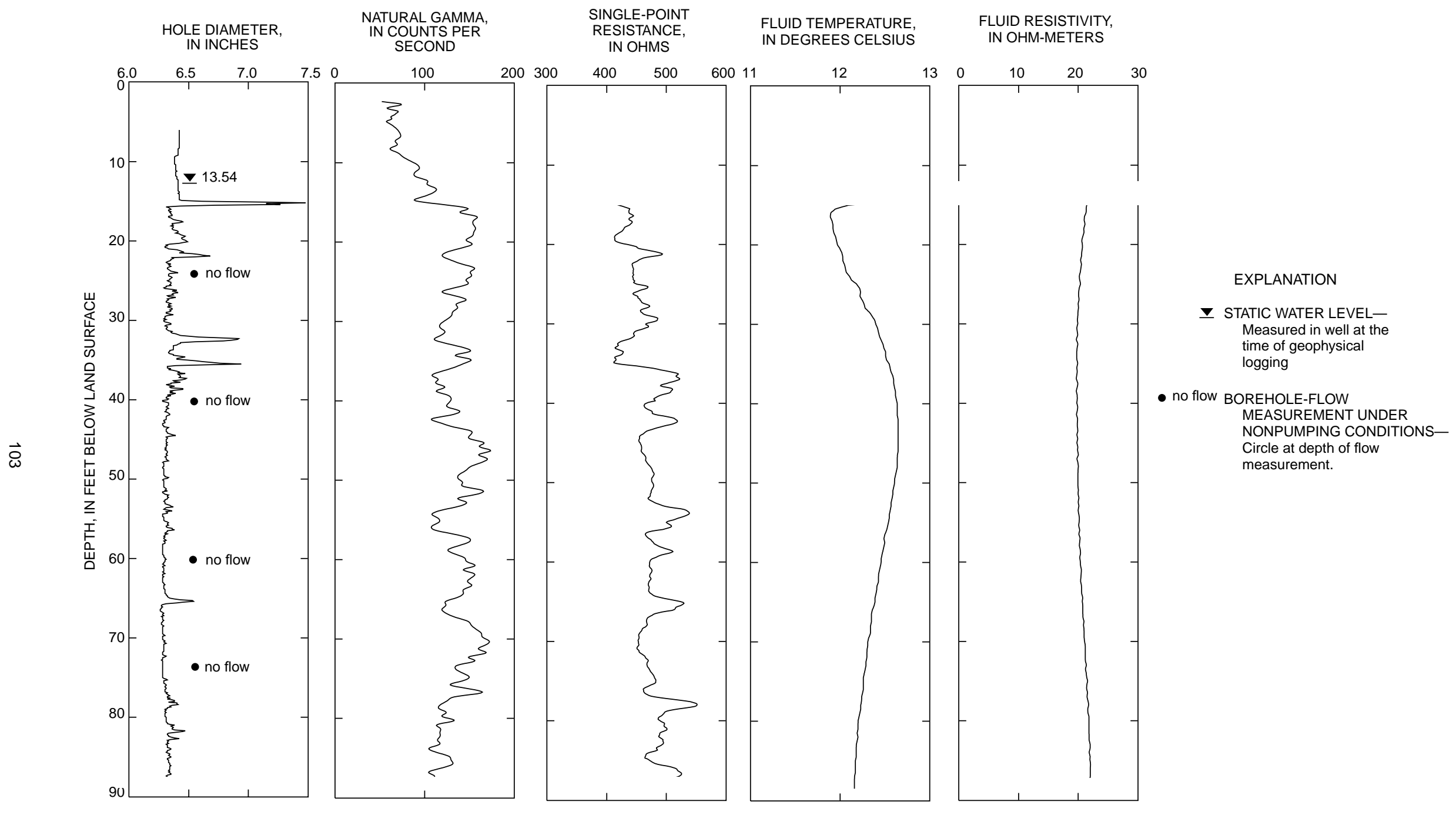

Figure 63. Borehole geophysical logs and direction of nonpumping flow within borehole MG-1611 (Keystone 1S), North Penn Area 6 Superfund Site, Lansdale, Montgomery County, Pennsylvania. 


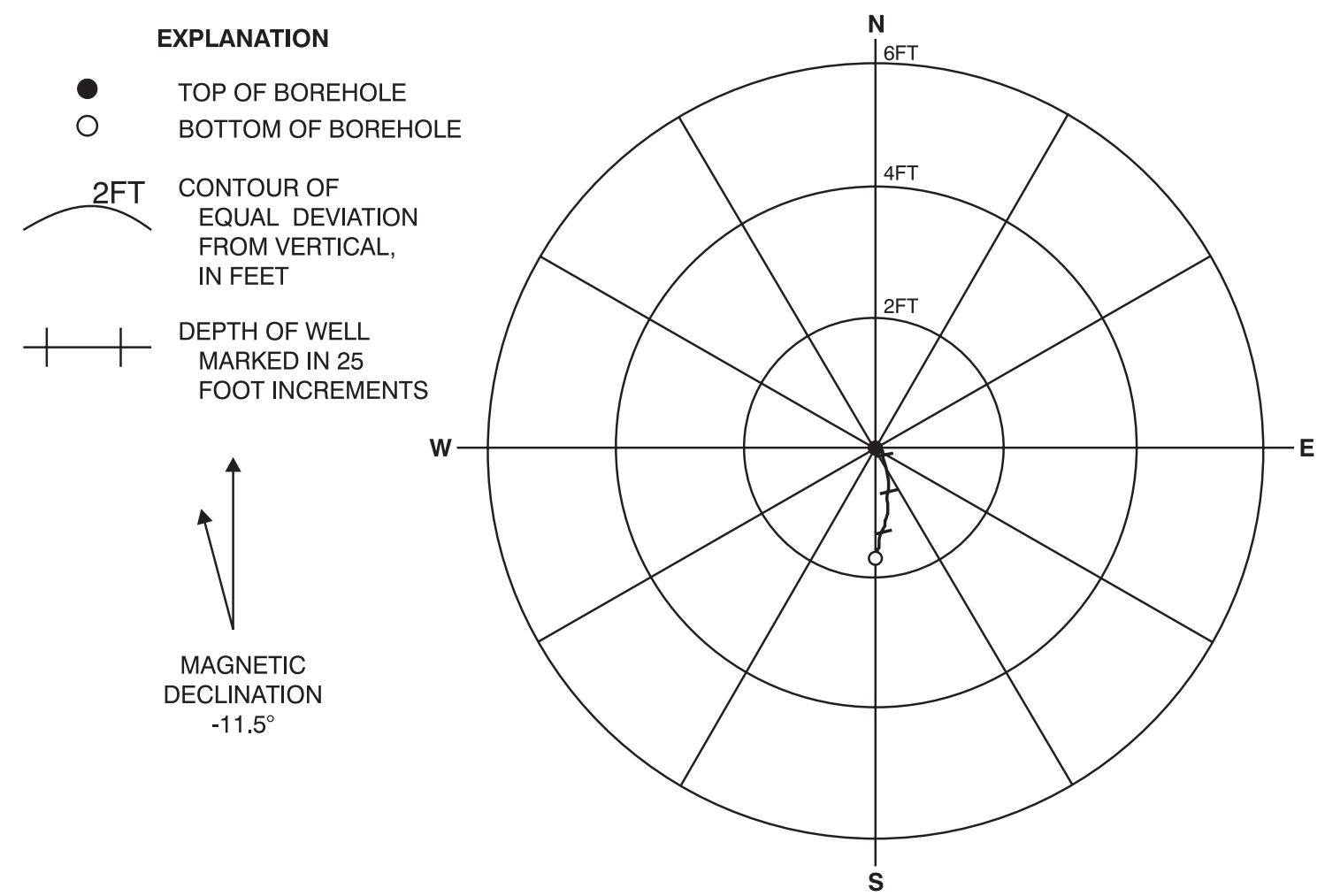

Figure 64. Magnitude and direction of deviation from vertical of borehole MG-1611 (Keystone 1S).

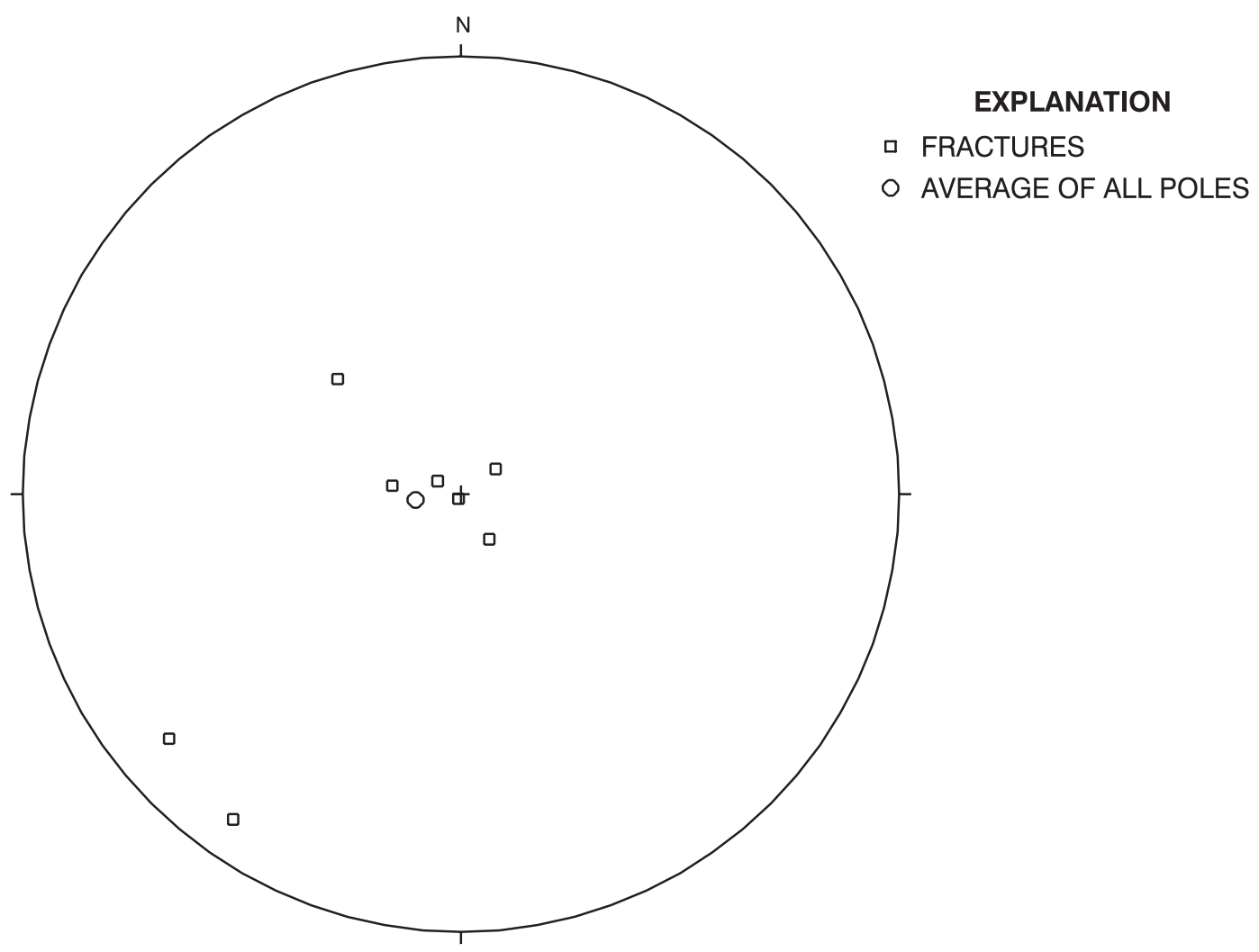

Figure 65. Equal-area lower hemisphere, stereographic projection of poles perpendicular to fracture planes in borehole MG-1611 (Keystone 1S). 


\section{MG-1612 (Electra 1I)}

The caliper $\log$ shows the total depth of the borehole is $180 \mathrm{ft}$ and it is cased with 10 -in.-diameter casing to $20 \mathrm{ft}$ bls (fig. 66). The caliper log shows major fractures at 20-21 and $42-43 \mathrm{ft}$ bls plus other minor fractures throughout the open-hole interval. The static water level at the time of logging was $50.33 \mathrm{ft}$ bls. The fluidtemperature log shows a change in slope at $110 \mathrm{ft}$ bls that correlates to a minor fracture zone shown on the caliper log and may indicate a water-producing zone. Under nonpumping conditions, the heatpulse flowmeter measured minor upward borehole flow at $68 \mathrm{ft}$ bls and no flow at 54, 92, 120, and 150 (table 42). The geophysical logs and the heatpulse-flowmeter measurements indicate water enters the borehole through fractures at 71-89 ft bls, moves upward, and exits the borehole through the fracture at 62-65 ft bls. This well was drilled deeper after it was initially logged in order to intersect additional water-producing zones, as described in the section MG-1612 (Electra 1D).

Table 42. Summary of heatpulse-flowmeter measurements for borehole MG-1612 (Electra 1I) at North Penn Area 6 Superfund Site, Lansdale, Montgomery County, Pennsylvania

[gal/min, gallon per minute]

\begin{tabular}{ccc}
\hline $\begin{array}{c}\text { Depth } \\
\text { (feet below } \\
\text { land surface) }\end{array}$ & $\begin{array}{c}\text { Flow rate } \\
\text { (gal/min) } \\
\text { nonpumping } \\
\text { conditions }\end{array}$ & $\begin{array}{c}\text { Flow direction } \\
\text { nonpumping } \\
\text { conditions }\end{array}$ \\
\hline 54 & no flow & not determined \\
68 & 0.12 & up \\
92 & no flow & not determined \\
120 & no flow & not determined \\
150 & no flow & not determined \\
\hline
\end{tabular}




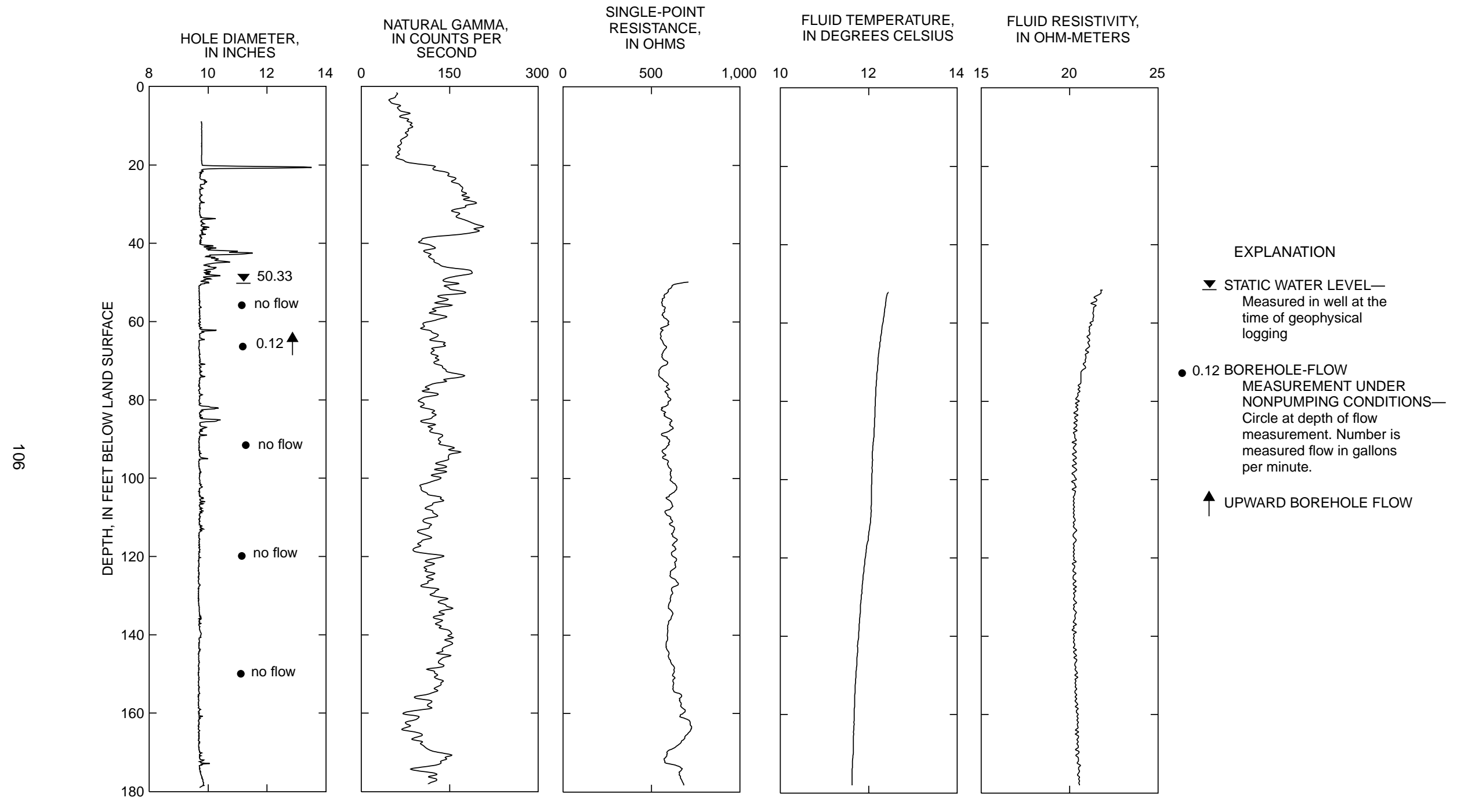

Figure 66. Borehole geophysical logs and direction of nonpumping flow within borehole MG-1612 (Electra 1I), North Penn Area 6 Superfund Site, Lansdale, Montgomery County, Pennsylvania. 


\section{MG-1612 (Electra 1D)}

Borehole MG-1612 was drilled deeper to intersect additional water-producing zones and renamed "Electra 1D" by Black and Veatch Waste Science, Inc. The caliper log shows the total depth of the borehole is $384 \mathrm{ft}$ and it is cased with 10-in.-diameter casing to $20 \mathrm{ft}$ bls (fig. 67). The caliper log shows major fracture zones at 20-21 and 40-50 ft bls plus other minor fractures throughout the open-hole interval. The static water level at the time of logging was $49.80 \mathrm{ft}$ bls. The natural-gamma log shows shale units with elevated gamma readings at 308-310 ft bls and 312-314 ft bls that may be used for stratigraphic correlation of geologic units with other wells. The fluid-resistivity and fluid-temperature logs show changes in slope at 65, 105, and $312 \mathrm{ft}$ bls that correlate to fractures shown on the caliper log and indicate possible water-producing zones. Under nonpumping conditions, the heatpulse flowmeter measured upward borehole flow at 66, 92, 122, $150,200,260,302,320$, and $360 \mathrm{ft}$ bls (table 43). The geophysical logs and the heatpulse-flowmeter measurements indicate water enters the borehole through fractures at 310-312, 330-340, and approximately $370-382 \mathrm{ft}$ bls, moves upward, and exits the borehole through the fractures at $94-115 \mathrm{ft}$ bls and approximately $50-54 \mathrm{ft}$ bls.

Table 43. Summary of heatpulse-flowmeter measurements for the deeper borehole MG-1612 (Electra 1D) at North Penn Area 6 Superfund Site, Lansdale, Montgomery County, Pennsylvania

[gal/min, gallon per minute]

\begin{tabular}{ccc}
\hline $\begin{array}{c}\text { Depth } \\
\text { (feet below } \\
\text { land surface) }\end{array}$ & $\begin{array}{c}\text { Flow rate } \\
\text { (gal/min) } \\
\text { nonpumping } \\
\text { conditions }\end{array}$ & $\begin{array}{c}\text { Flow direction } \\
\text { nonpumping } \\
\text { conditions }\end{array}$ \\
\hline 66 & 0.18 & up \\
92 & .12 & up \\
122 & .64 & up \\
150 & .70 & up \\
200 & .73 & up \\
260 & .69 & up \\
302 & .70 & up \\
320 & .40 & up \\
360 & .30 & up \\
\hline
\end{tabular}




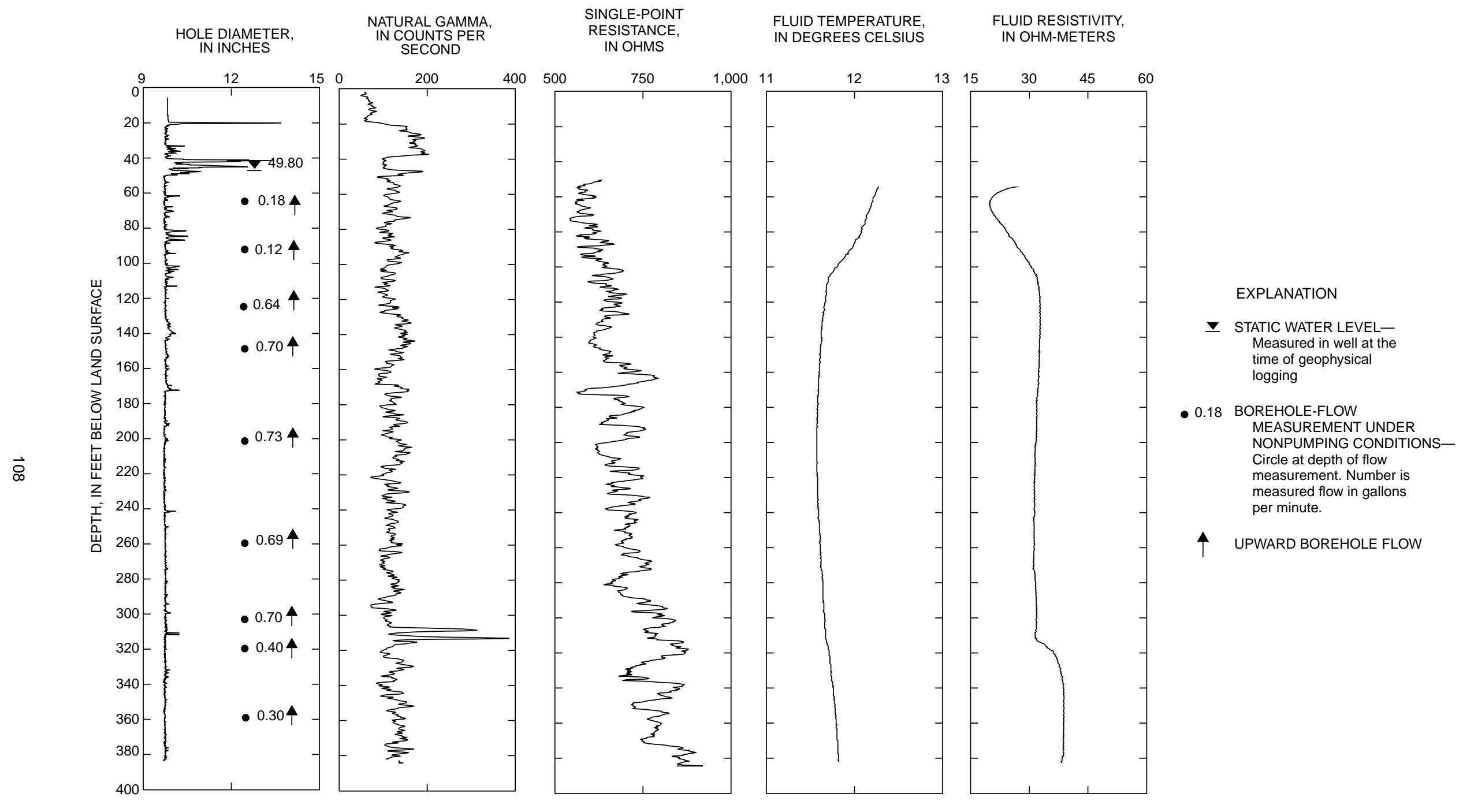

Figure 67. Borehole geophysical logs and direction of nonpumping flow within the deeper borehole MG-1612 (Electra 1D), North Penn Area 6 Superfund Site, Lansdale, Montgomery County, Pennsylvania. 


\section{MG-1613 (Precision 11)}

The caliper log shows the total depth of the borehole is $179 \mathrm{ft}$ and it is cased with 10-in.-diameter casing to $19 \mathrm{ft}$ bls (fig. 68). The caliper log shows major fractures at 19, 40-44, and 47-48 ft bls plus other minor fractures throughout the open-hole interval. The static water level at the time of logging was $25.58 \mathrm{ft}$ bls. The fluid-resistivity log shows changes in slope at 28,74,94,142, and $172 \mathrm{ft}$ bls that approximately correlate to fractures shown on the caliper log, which may indicate water-producing zones. The fluid-temperature log shows changes in slope at 40, 94-96, and 130-160 ft bls. The natural-gamma log shows shale units with elevated gamma readings at $82-88$ and $121-139 \mathrm{ft}$ bls that may be used for stratigraphic correlation of geologic units with other wells. Under nonpumping conditions, the heatpulse flowmeter measured upward borehole flow at 60 and $78 \mathrm{ft}$ bls and no flow at 32, 88, 110, 130, and $152 \mathrm{ft}$ bls (table 44). The geophysical logs and the heatpulse-flowmeter measurements indicate that under nonpumping conditions, water enters the borehole through fractures at 72-74 ft bls, moves upward, and exits the borehole through the fractures at 40-55 ft bls. A submersible pump was placed at $35 \mathrm{ft}$ bls, and the borehole was pumped at $2 \mathrm{gal} / \mathrm{min}$. The water level in the borehole declined $0.87 \mathrm{ft}$ after 48 minutes. Under pumping conditions, the heatpulse flowmeter measured upward borehole flow at $60 \mathrm{ft}$ bls and no flow at 110, 130, and $152 \mathrm{ft}$ bls. Under pumping conditions, the geophysical logs and the heatpulse-flowmeter measurements indicate a minor quantity of water enters the borehole through fractures below $60 \mathrm{ft}$ bls but above $110 \mathrm{ft}$ bls, and the largest quantity of water enters the borehole through the fractures at $40-55 \mathrm{ft}$ bls.

Table 44. Summary of heatpulse-flowmeter measurements for borehole MG-1613 (Precision 1I) at North Penn Area 6 Superfund Site, Lansdale, Montgomery County, Pennsylvania

[gal/min, gallon per minute]

\begin{tabular}{ccccc}
\hline $\begin{array}{c}\text { Depth } \\
\text { (feet below } \\
\text { land surface) }\end{array}$ & $\begin{array}{c}\text { Flow rate } \\
\text { (gal/min) } \\
\text { nonpumping } \\
\text { conditions }\end{array}$ & $\begin{array}{c}\text { Flow direction } \\
\text { nonpumping } \\
\text { conditions }\end{array}$ & $\begin{array}{c}\text { Flow rate } \\
\text { (gal/min) } \\
\text { pumping } \\
\text { conditions }\end{array}$ & $\begin{array}{c}\text { Flow direction } \\
\text { pumping } \\
\text { conditions }\end{array}$ \\
\hline 32 & no flow & not determined & no data & no data \\
60 & 0.32 & up & 0.37 & up \\
78 & up & no data & no data \\
88 & no flow & not determined & no data & no data \\
110 & no flow & not determined & no flow & not determined \\
130 & no flow & not determined & no flow & not determined \\
152 & no flow & not determined & no flow & not determined \\
\hline
\end{tabular}




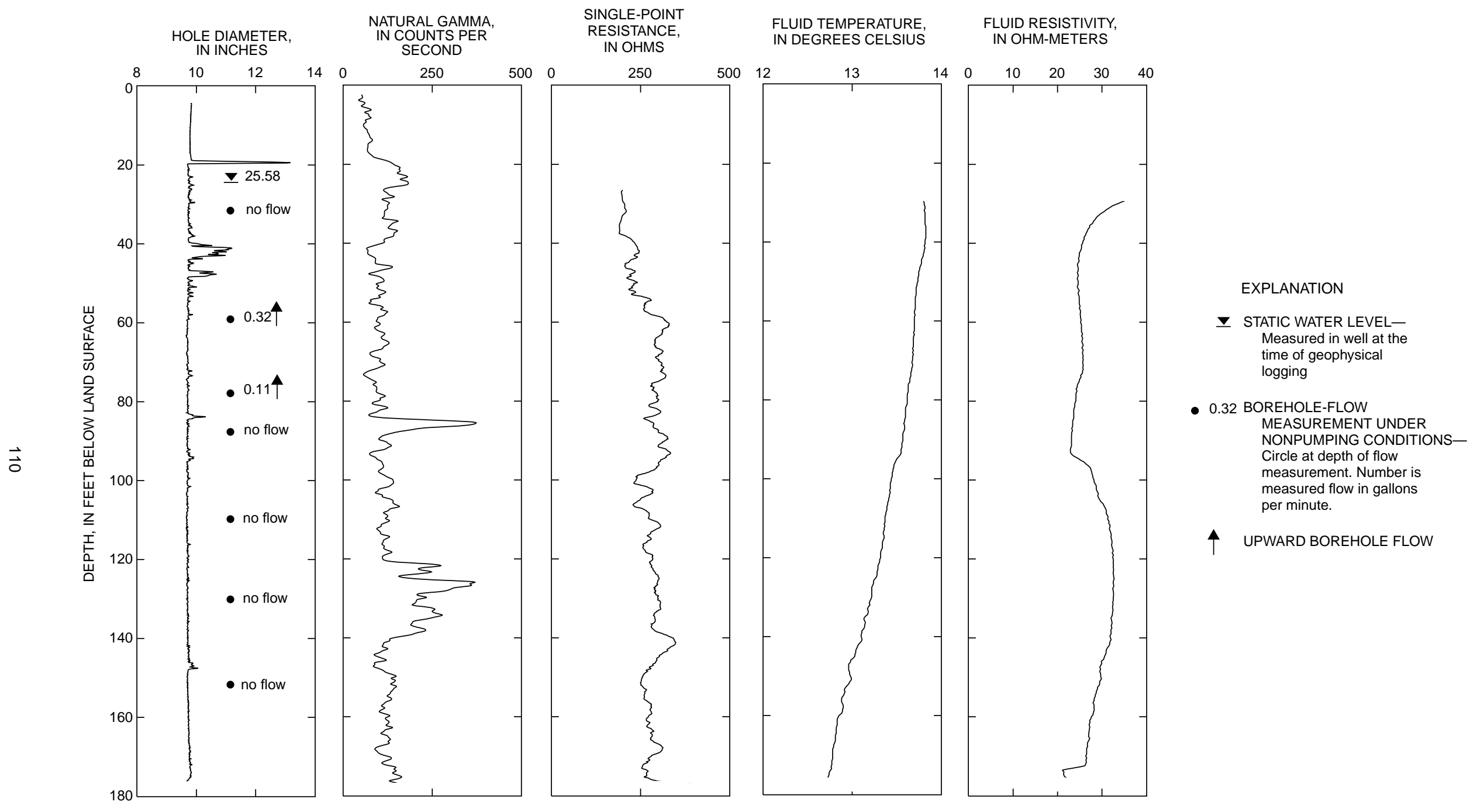

Figure 68. Borehole geophysical logs and direction of nonpumping flow within borehole MG-1613 (Precision 1I), North Penn Area 6 Superfund Site, Lansdale, Montgomery County, Pennsylvania. 


\section{MG-1613 (Precision 1D)}

Borehole MG-1613 was drilled deeper to intersect additional water-producing zones and renamed "Precision 1D" by Black and Veatch Waste Science, Inc. The caliper log shows the total depth of the borehole is $320 \mathrm{ft}$ and it is cased with 6.5-in.-diameter casing to $181 \mathrm{ft} \mathrm{bls} \mathrm{(fig.} \mathrm{69).} \mathrm{The} \mathrm{caliper} \mathrm{log} \mathrm{shows} \mathrm{only} \mathrm{minor}$ fractures throughout the open-hole interval. The static water level at the time of logging was $37.08 \mathrm{ft}$ bls. The fluid-resistivity log shows changes in slope at 184, 270-282, and $290 \mathrm{ft}$ bls that may indicate waterproducing zones. The driller's log reports minor water-producing zones below 220 and at $280 \mathrm{ft}$ bls. The natural-gamma log shows shale units with elevated gamma readings at 83-87 and 121-138 ft bls that may be used for stratigraphic correlation of geologic units with other wells. Under nonpumping conditions, the heatpulse flowmeter measured no borehole flow at 190, 220, 260, 275, and $288 \mathrm{ft}$ bls (table 45). The borehole remains as an open borehole from 182 to $320 \mathrm{ft}$ bls.

Table 45. Summary of heatpulse-flowmeter measurements for the deeper borehole MG-1613 (Precision 1D) at North Penn Area 6 Superfund Site, Lansdale, Montgomery County, Pennsylvania

[gal/min, gallon per minute]

\begin{tabular}{ccc}
\hline $\begin{array}{c}\text { Depth } \\
\text { (feet below } \\
\text { land surface) }\end{array}$ & $\begin{array}{c}\text { Flow rate } \\
\text { (gal/min) } \\
\text { nonpumping } \\
\text { conditions }\end{array}$ & $\begin{array}{c}\text { Flow direction } \\
\text { nonpumping } \\
\text { conditions }\end{array}$ \\
\hline 190 & no flow & not determined \\
220 & no flow & not determined \\
260 & no flow & not determined \\
275 & no flow & not determined \\
288 & no flow & not determined \\
\hline
\end{tabular}




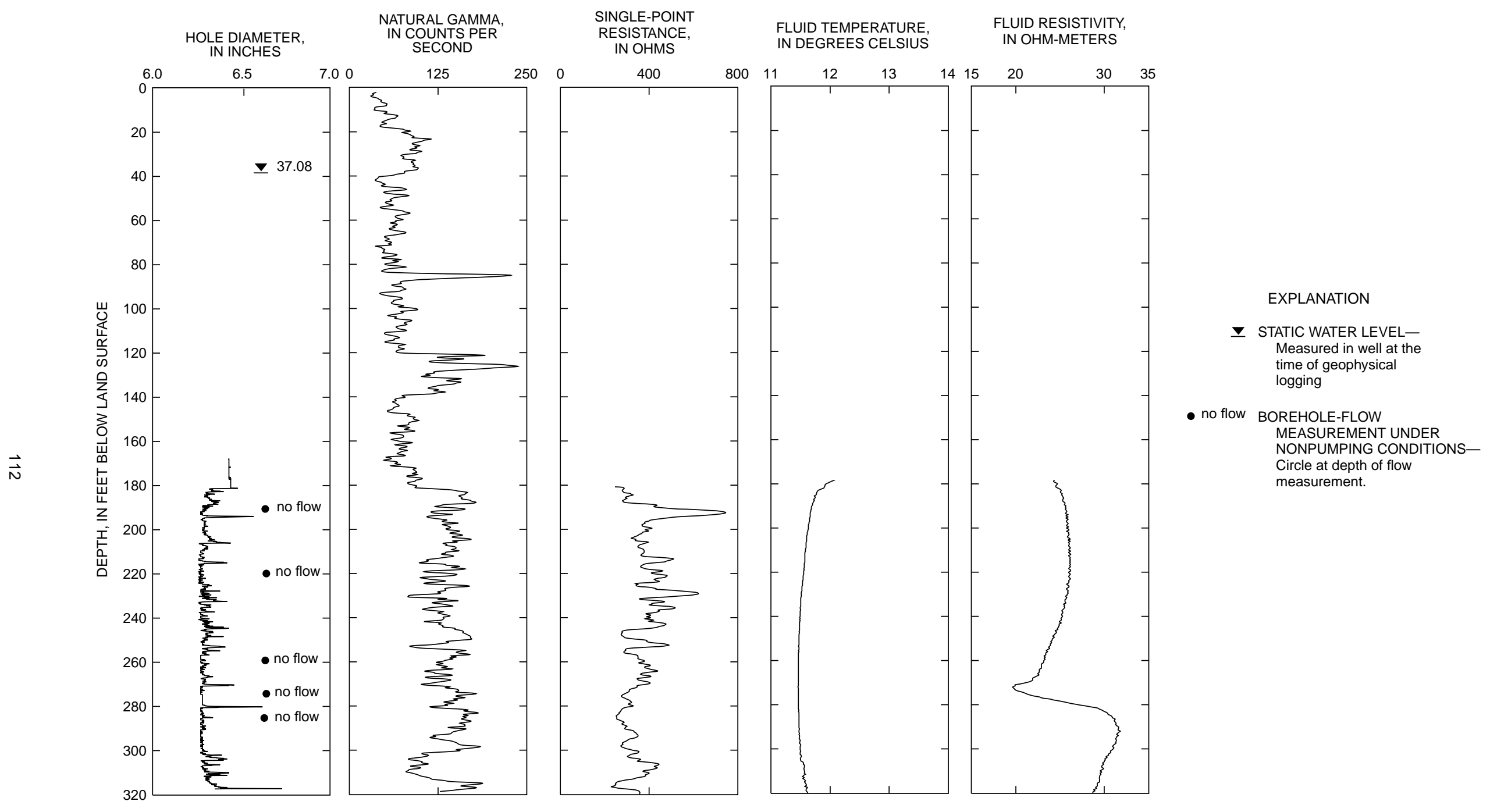

Figure 69. Borehole geophysical logs and direction of nonpumping flow within the deeper borehole MG-1613 (Precision 1D), North Penn Area 6 Superfund Site, Lansdale, Montgomery County, Pennsylvania. 


\section{MG-1614 (Electra 1S)}

The caliper log shows the total depth of the borehole is $121 \mathrm{ft}$ and it is cased with 6.5-in.-diameter casing to $18 \mathrm{ft}$ bls (fig. 70). The caliper log shows only minor fractures throughout the open-hole interval. The static water level at the time of logging was $50.52 \mathrm{ft}$ bls. The natural-gamma log shows shale units with elevated gamma readings at 49-55 ft bls that may be used for stratigraphic correlation of geologic units with other wells. The fluid-resistivity log shows a change in slope from $51-68 \mathrm{ft}$ bls that may indicate waterproducing zones. Under nonpumping conditions, the heatpulse flowmeter measured upward borehole flow at 58,70,80, and $100 \mathrm{ft}$ bls (table 46). The geophysical logs and the heatpulse-flowmeter measurements indicate water enters the borehole through fractures between 102-120 ft bls, moves upward, and exits the borehole through the fractures at about 50-56 and between 70-80 ft bls.

Table 46. Summary of heatpulse-flowmeter measurements for borehole MG-1614

(Electra 1S) at North Penn Area 6 Superfund

Site, Lansdale, Montgomery County, Pennsylvania

[gal/min, gallon per minute]

\begin{tabular}{ccc}
\hline $\begin{array}{c}\text { Depth } \\
\text { (feet below } \\
\text { land surface) }\end{array}$ & $\begin{array}{c}\text { Flow rate } \\
\text { (gal/min) } \\
\text { nonpumping } \\
\text { conditions }\end{array}$ & $\begin{array}{c}\text { Flow direction } \\
\text { nonpumping } \\
\text { conditions }\end{array}$ \\
\hline 58 & 0.10 & up \\
70 & .11 & up \\
80 & .18 & up \\
100 & .22 & up \\
\hline
\end{tabular}




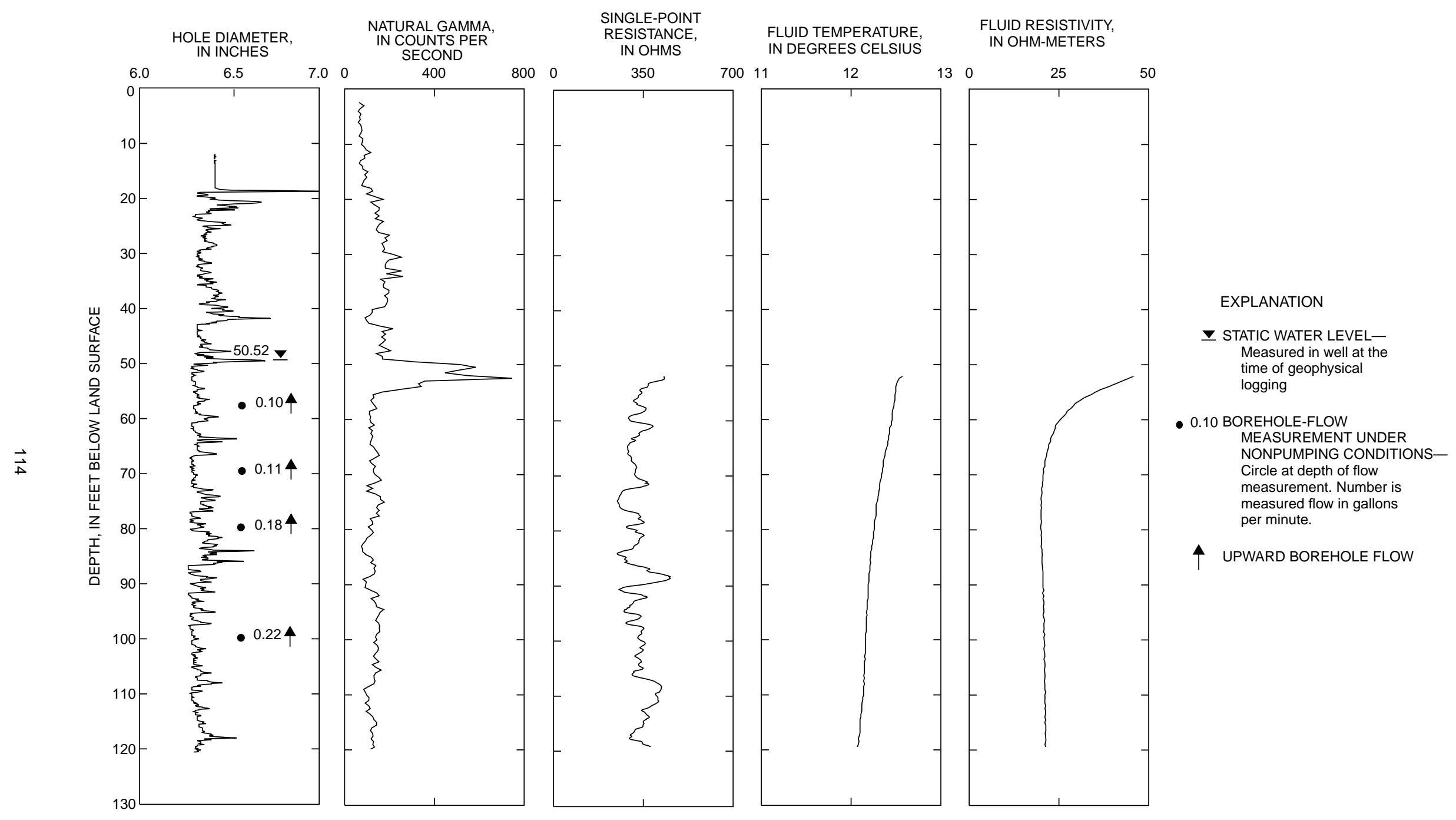

Figure 70. Borehole geophysical logs and direction of nonpumping flow within borehole MG-1614 (Electra 1S), North Penn Area 6 Superfund Site, Lansdale, Montgomery County, Pennsylvania. 


\section{MG-1615 (Westside 1I)}

The caliper log shows the total depth of the borehole is $148 \mathrm{ft}$ and it is cased with 10-in.-diameter casing to $18.5 \mathrm{ft}$ bls (fig. 71). The caliper log shows major fractures at 19 and $45 \mathrm{ft}$ bls plus minor fractures throughout the open-hole interval. The static water level at the time of logging was $15.69 \mathrm{ft}$ bls. The naturalgamma log shows a shale unit with elevated gamma readings at 139-141 ft bls that may be used for stratigraphic correlation of geologic units with other wells. The fluid-resistivity and fluid-temperature logs show changes in slope at 40-55, 90, 122, and $134 \mathrm{ft}$ bls that may indicate water-producing zones. Under nonpumping conditions, the heatpulse flowmeter measured upward borehole flow at 34, 66, 106, and $126 \mathrm{ft}$ bls (table 47). The geophysical logs and the heatpulse-flowmeter measurements indicate water enters the borehole through fractures at 72-74, 119, and 140-148 ft bls, moves upward, and exits the borehole through fractures at $19-28$ and $40-55 \mathrm{ft}$ bls.

Table 47. Summary of heatpulse-flowmeter measurements for borehole MG-1615 (Westside 1I) at North Penn Area 6 Superfund Site, Lansdale, Montgomery County, Pennsylvania

[gal/min, gallon per minute]

\begin{tabular}{ccc}
\hline $\begin{array}{c}\text { Depth } \\
\text { feet below } \\
\text { land surface }\end{array}$ & $\begin{array}{c}\text { Flow rate } \\
\text { (gal/min) } \\
\text { nonpumping } \\
\text { conditions }\end{array}$ & $\begin{array}{c}\text { Flow direction } \\
\text { nonpumping } \\
\text { conditions }\end{array}$ \\
\hline 34 & 0.27 & up \\
66 & .52 & up \\
106 & .34 & up \\
126 & .07 & up \\
\hline
\end{tabular}




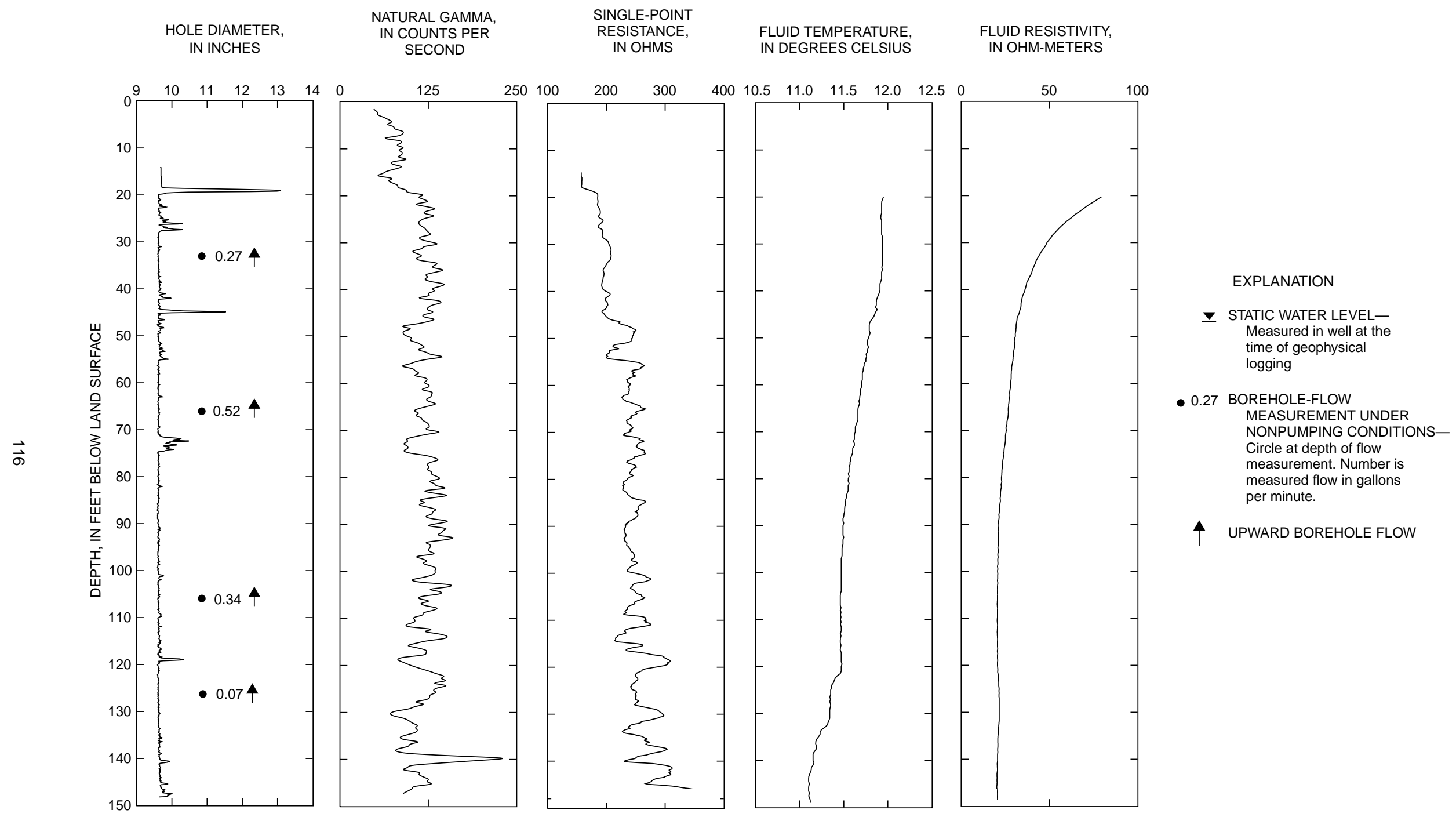

Figure 71. Borehole geophysical logs and direction of nonpumping flow within borehole MG-1615 (Westside 1I), North Penn Area 6 Superfund Site, Lansdale, Montgomery County, Pennsylvania. 


\section{MG-1616 (Precision 1S)}

The caliper log shows the total depth of the borehole is $101 \mathrm{ft}$ and it is cased with 6-in.-diameter casing to $20 \mathrm{ft}$ bls (fig. 72). The caliper log shows a major fracture at $51-53 \mathrm{ft}$ bls plus a few minor fractures throughout the open-hole interval. The static water level at the time of logging was $26.55 \mathrm{ft}$ bls. The naturalgamma log shows shale units with elevated gamma counts at 69 and $96-99 \mathrm{ft}$ bls that may be used for stratigraphic correlation of geologic units with other wells. The fluid-resistivity log shows changes in slope at 30-34, 42, 52, and $56 \mathrm{ft}$ bls that may indicate water-producing zones. The fluid-temperature log shows deflections in slope at 32 and $52 \mathrm{ft}$ bls that may indicate water-producing zones. Under nonpumping conditions, the heatpulse flowmeter measured upward borehole flow at 40,59, and $74 \mathrm{ft}$ bls and no flow at $90 \mathrm{ft}$ bls (table 48). The geophysical logs and the heatpulse-flowmeter measurements indicate water enters the borehole through fractures at $81 \mathrm{ft}$ bls, moves upward, and exits the borehole through fractures at 5153 and 30-34 ft bls.

Table 48. Summary of heatpulse-flowmeter measurements for borehole MG-1616 (Precision 1S) at North Penn Area 6 Superfund Site, Lansdale, Montgomery County, Pennsylvania

[gal/min, gallon per minute]

\begin{tabular}{ccc}
\hline $\begin{array}{c}\text { Depth } \\
\text { (feet below } \\
\text { land surface) }\end{array}$ & $\begin{array}{c}\text { Flow rate } \\
\text { (gal/min) } \\
\text { nonpumping } \\
\text { conditions }\end{array}$ & $\begin{array}{c}\text { Flow direction } \\
\text { nonpumping } \\
\text { conditions }\end{array}$ \\
\hline 40 & 0.06 & up \\
59 & .12 & up \\
74 & .11 & up \\
90 & no flow & not determined \\
\hline
\end{tabular}




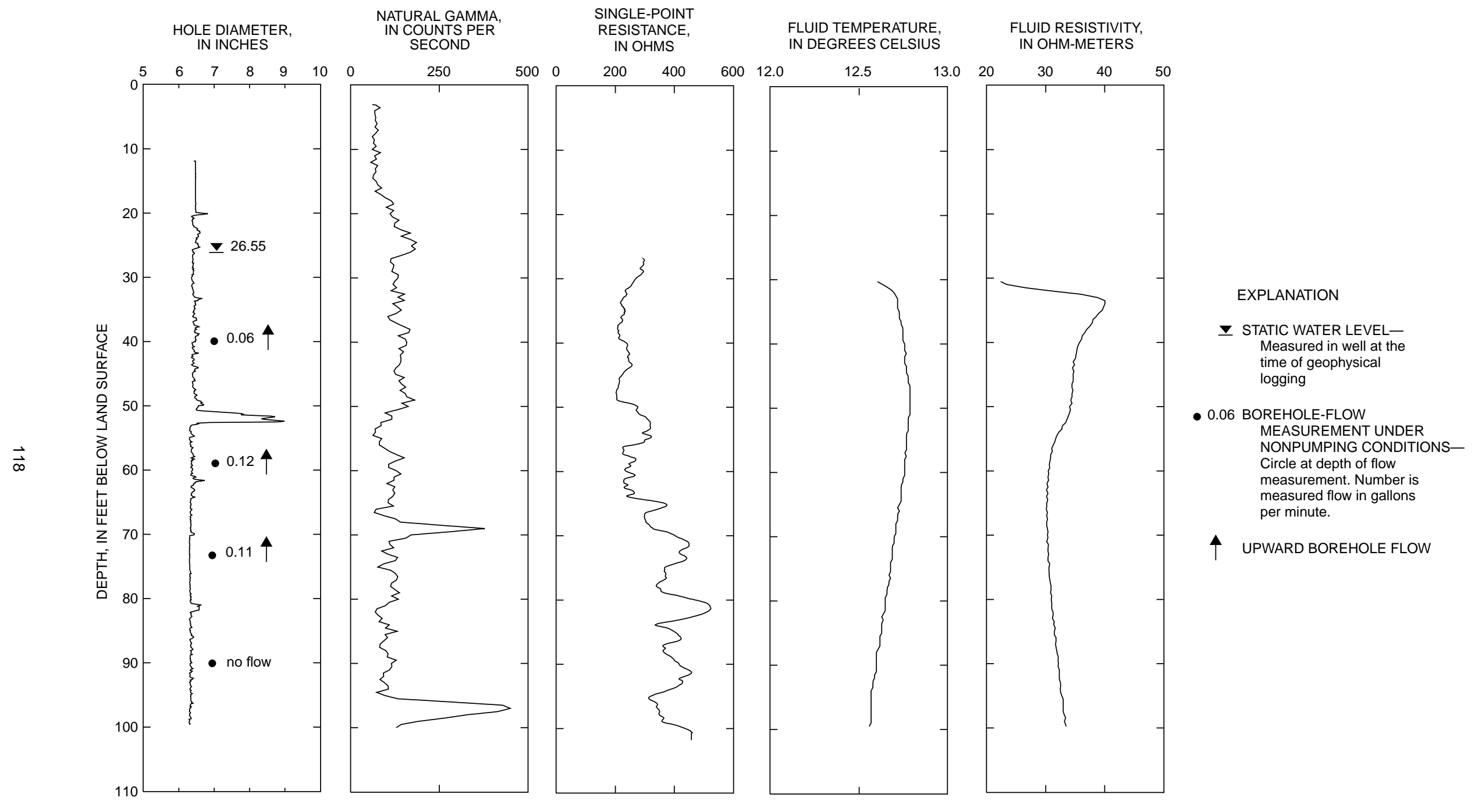

Figure 72. Borehole geophysical logs and direction of nonpumping flow within borehole MG-1616 (Precision 1S), North Penn Area 6 Superfund Site, Lansdale, Montgomery County, Pennsylvania. 


\section{MG-1617 (Westside 1S)}

The caliper log shows the total depth of the borehole is $49 \mathrm{ft}$ and it is cased with 6.5-in.-diameter casing to $19 \mathrm{ft}$ bls (fig. 73). The caliper log shows minor fractures at 19-20, 22, 30, and 39-40 ft bls. The static water level at the time of logging was $13.51 \mathrm{ft}$ bls. The fluid-resistivity log shows changes in slope at 19 and $30 \mathrm{ft}$ bls that may indicate water-producing zones. The driller's log reports water-producing zones at 40 and $55 \mathrm{ft}$ bls. Under nonpumping conditions, the heatpulse flowmeter measured no borehole flow at 25 and $36 \mathrm{ft}$ bls.

\section{MG-1618 (Lansdale Warehouse 1I)}

The caliper log shows the total depth of the borehole was $181 \mathrm{ft}$ and it was cased with 10-in.-diameter casing to $20 \mathrm{ft}$ bls at the time of logging (fig. 74). The caliper log shows a major fracture at 20-21 ft bls and numerous minor fractures throughout the open-hole interval. The static water level at the time of logging was $51.96 \mathrm{ft}$ bls. The fluid-resistivity log shows deflections in slope at 78 and $92 \mathrm{ft}$ bls that may suggest water-producing zones. The fluid-temperature log shows changes in slope at 78, 92, and $128 \mathrm{ft}$ bls that may indicate water-producing zones. Under nonpumping conditions, the heatpulse flowmeter measured upward borehole flow at $85 \mathrm{ft}$ bls and no flow at 70, 110, 145, and $170 \mathrm{ft}$ bls (table 49). The geophysical logs and the heatpulse-flowmeter measurements indicate water enters the borehole through fractures at $92 \mathrm{ft}$ bls, moves upward, and exits the borehole through fractures at 75-78 ft bls. The driller's log indicates about $20-25 \mathrm{gal} / \mathrm{min}$ of water is produced at $177 \mathrm{ft}$ bls.

Table 49. Summary of heatpulse-flowmeter measurements for borehole MG-1618 (Lansdale Warehouse 1I) at North Penn Area 6 Superfund Site, Lansdale, Montgomery County, Pennsylvania [gal/min, gallon per minute]

\begin{tabular}{ccc}
\hline $\begin{array}{c}\text { Depth } \\
\text { (feet below } \\
\text { land surface) }\end{array}$ & $\begin{array}{c}\text { Flow rate } \\
\text { (gal/min) } \\
\text { nonpumping } \\
\text { conditions }\end{array}$ & $\begin{array}{c}\text { Flow direction } \\
\text { nonpumping } \\
\text { conditions }\end{array}$ \\
\hline 70 & no flow & not determined \\
85 & 0.10 & up \\
110 & no flow & not determined \\
145 & no flow & not determined \\
170 & no flow & not determined \\
\hline
\end{tabular}




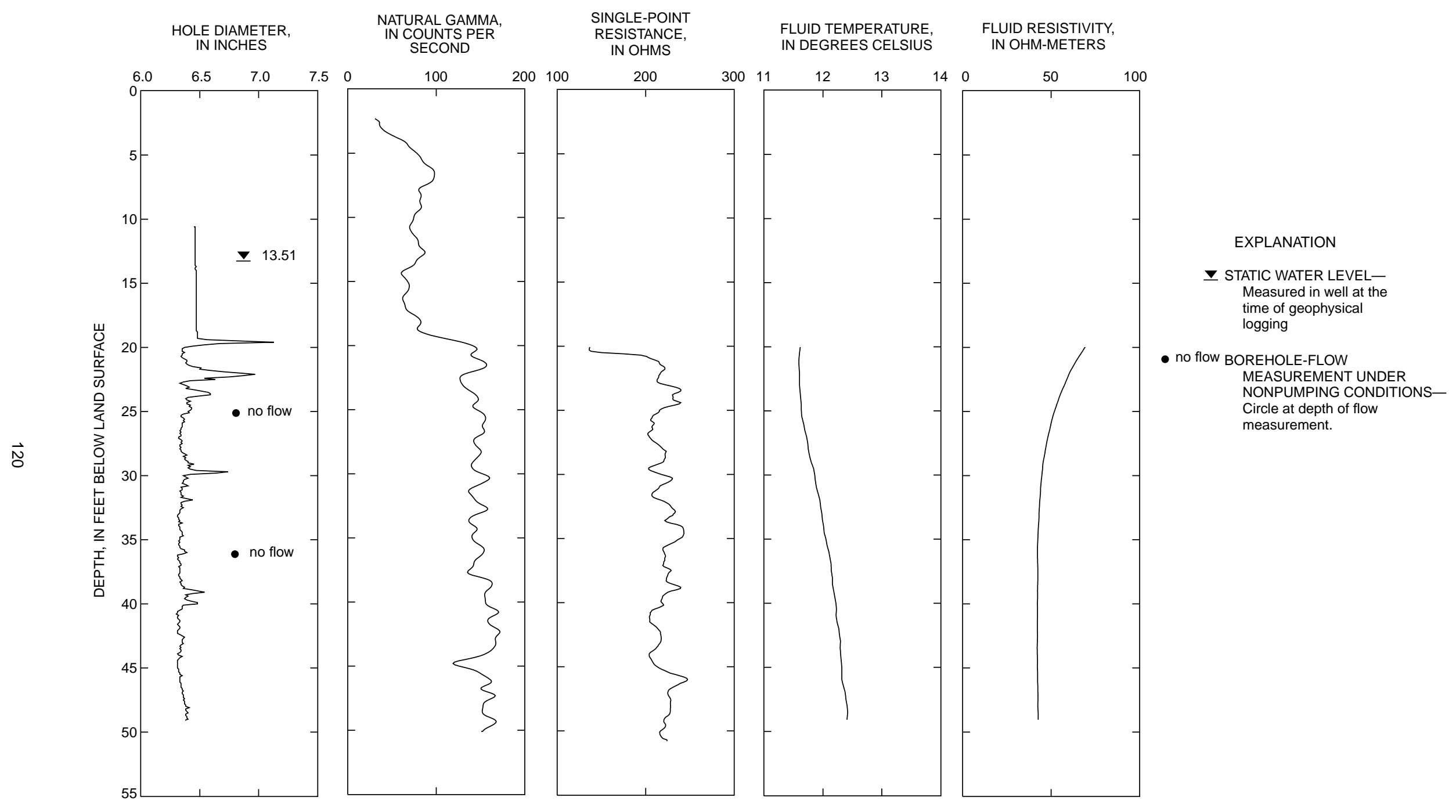

Figure 73. Borehole geophysical logs and direction of nonpumping flow within borehole MG-1617 (Westside 1S), North Penn Area 6 Superfund Site, Lansdale, Montgomery County, Pennsylvania. 

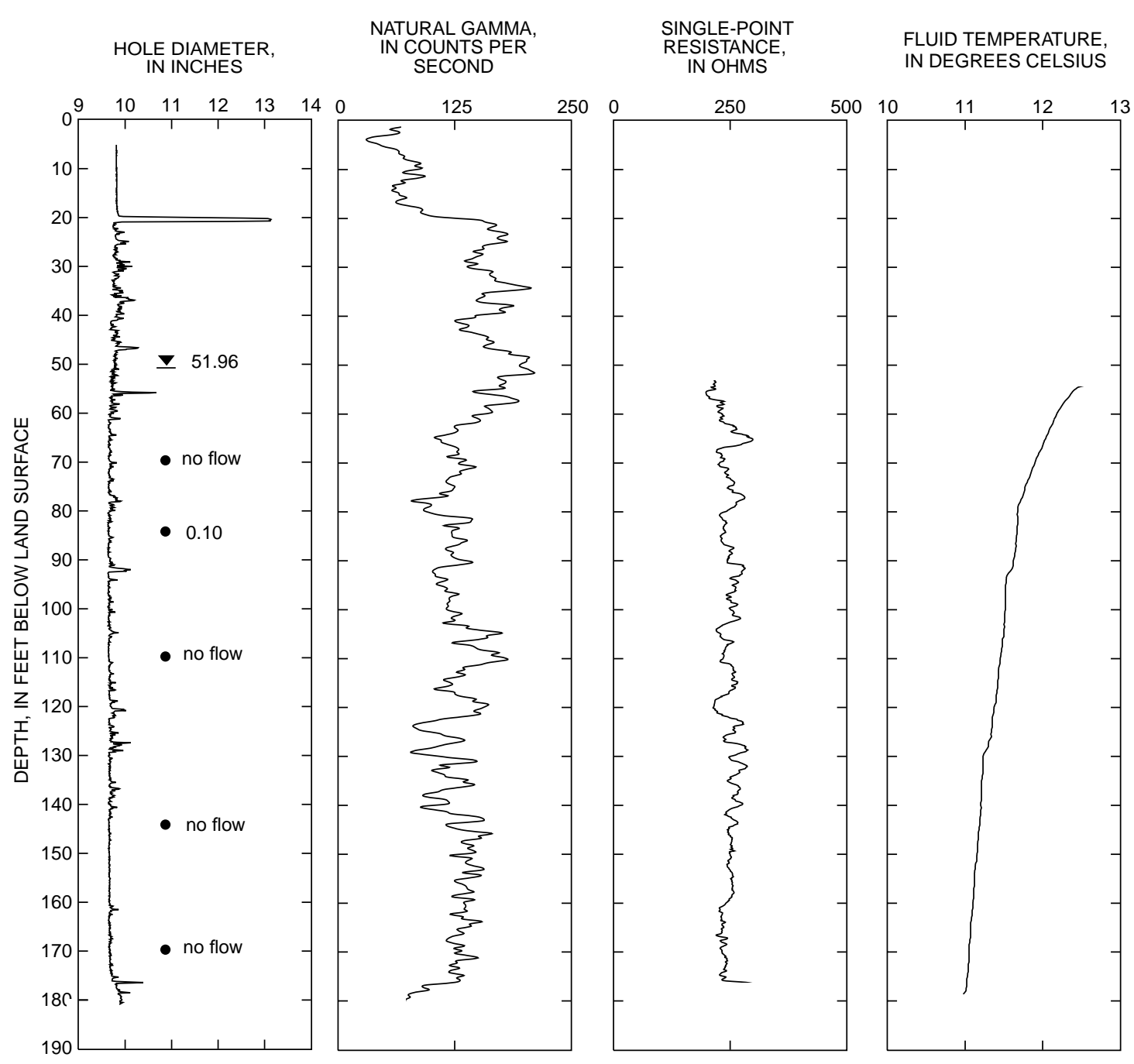

FLUID RESISTIVITY,
IN OHM-METERS

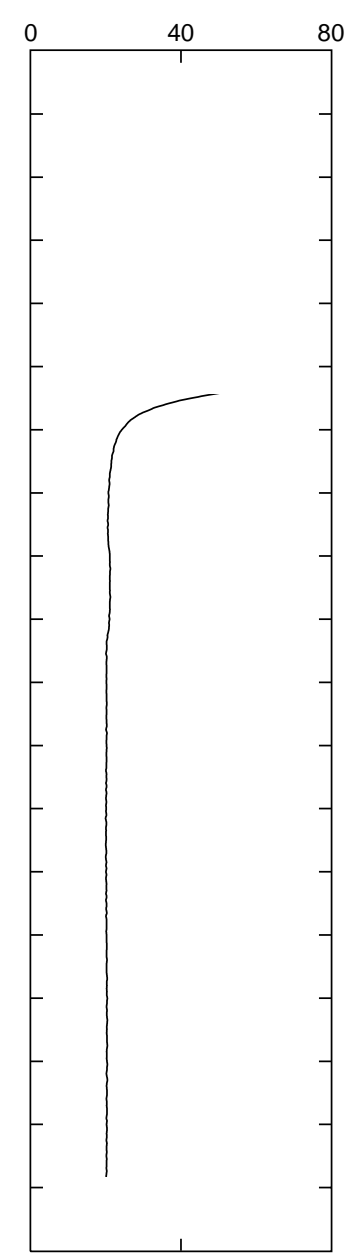

EXPLANATION

- STATIC WATER LEVELMeasured in well at the time of geophysical logging

- 0.10 BOREHOLE-FLOW MEASUREMENT UNDER NONPUMPING CONDITIONSCircle at deph of flow measurement. Number is measured flow in gallons per minute.

个 UPWARD BOREHOLE FLOW

Figure 74. Borehole geophysical logs and direction of nonpumping flow within borehole MG-1618 (Lansdale Warehouse 1I), North Penn Area 6 Superfund Site, Lansdale, Montgomery County, Pennsylvania. 


\section{MG-1619 (Keystone 2l)}

The caliper $\log$ shows the total depth of the borehole is $150 \mathrm{ft}$ and it is cased with 10-in.-diameter casing to $20 \mathrm{ft}$ bls at the time of logging (fig. 75). The caliper log shows a major fracture at 20-21 ft bls plus minor fractures throughout the open-hole interval. The static water level at the time of logging was $11.92 \mathrm{ft} b l s$. The natural-gamma log shows a shale unit with elevated gamma readings at $86-88 \mathrm{ft}$ bls that may be used for stratigraphic correlation of geologic units with other wells. The fluid-temperature log shows a change in slope at 20-22 ft bls that indicates a water-producing zone. The fluid-resistivity log shows deflections in slope at 49,86, and $97 \mathrm{ft}$ bls. Those deflections in slope correspond to minor fractures identified on the caliper log and suggest water-producing zones. Under nonpumping conditions, the heatpulse flowmeter measured upward borehole flow at 50 and $70 \mathrm{ft}$ bls but no flow at 90, 110, and $134 \mathrm{ft}$ bls (table 50). The geophysical logs and the heatpulse-flowmeter measurements indicate water enters the borehole through fractures at $85 \mathrm{ft}$ bls, moves upward, and exits the borehole through fractures at 20-42 ft bls. A submersible pump was placed at $30 \mathrm{ft}$ bls, and the borehole was pumped at $1.5 \mathrm{gal} / \mathrm{min}$. The water level in the borehole declined $0.25 \mathrm{ft}$ after $40 \mathrm{~min}$. Under pumping conditions, the heatpulse flowmeter measured upward borehole flow at 50, 70, and $90 \mathrm{ft}$ bls and no flow at 110 and $134 \mathrm{ft}$ bls. Under pumping conditions, the geophysical logs and the heatpulse-flowmeter measurements indicate a minor quantity of water enters the borehole through fractures at 90-108 ft bls; the largest quantity of water enters the borehole through the fracture at $86 \mathrm{ft}$ bls.

Table 50. Summary of heatpulse-flowmeter measurements for borehole MG-1619 (Keystone 2I) at North Penn Area 6 Superfund Site, Lansdale, Montgomery County, Pennsylvania

[gal/min, gallon per minute]

\begin{tabular}{|c|c|c|c|c|}
\hline $\begin{array}{c}\text { Depth } \\
\text { (feet below } \\
\text { land surface) }\end{array}$ & $\begin{array}{c}\text { Flow rate } \\
\text { (gal/min) } \\
\text { nonpumping } \\
\text { conditions }\end{array}$ & $\begin{array}{c}\text { Flow direction } \\
\text { nonpumping } \\
\text { conditions }\end{array}$ & $\begin{array}{c}\text { Flow rate } \\
\text { (gal/min) } \\
\text { pumping } \\
\text { conditions }\end{array}$ & $\begin{array}{c}\text { Flow direction } \\
\text { pumping } \\
\text { conditions }\end{array}$ \\
\hline 50 & 0.08 & up & 0.60 & up \\
\hline 70 & .11 & up & .60 & up \\
\hline 90 & no flow & not determined & .08 & up \\
\hline 110 & no flow & not determined & no flow & not determined \\
\hline 134 & no flow & not determined & no flow & not determined \\
\hline
\end{tabular}




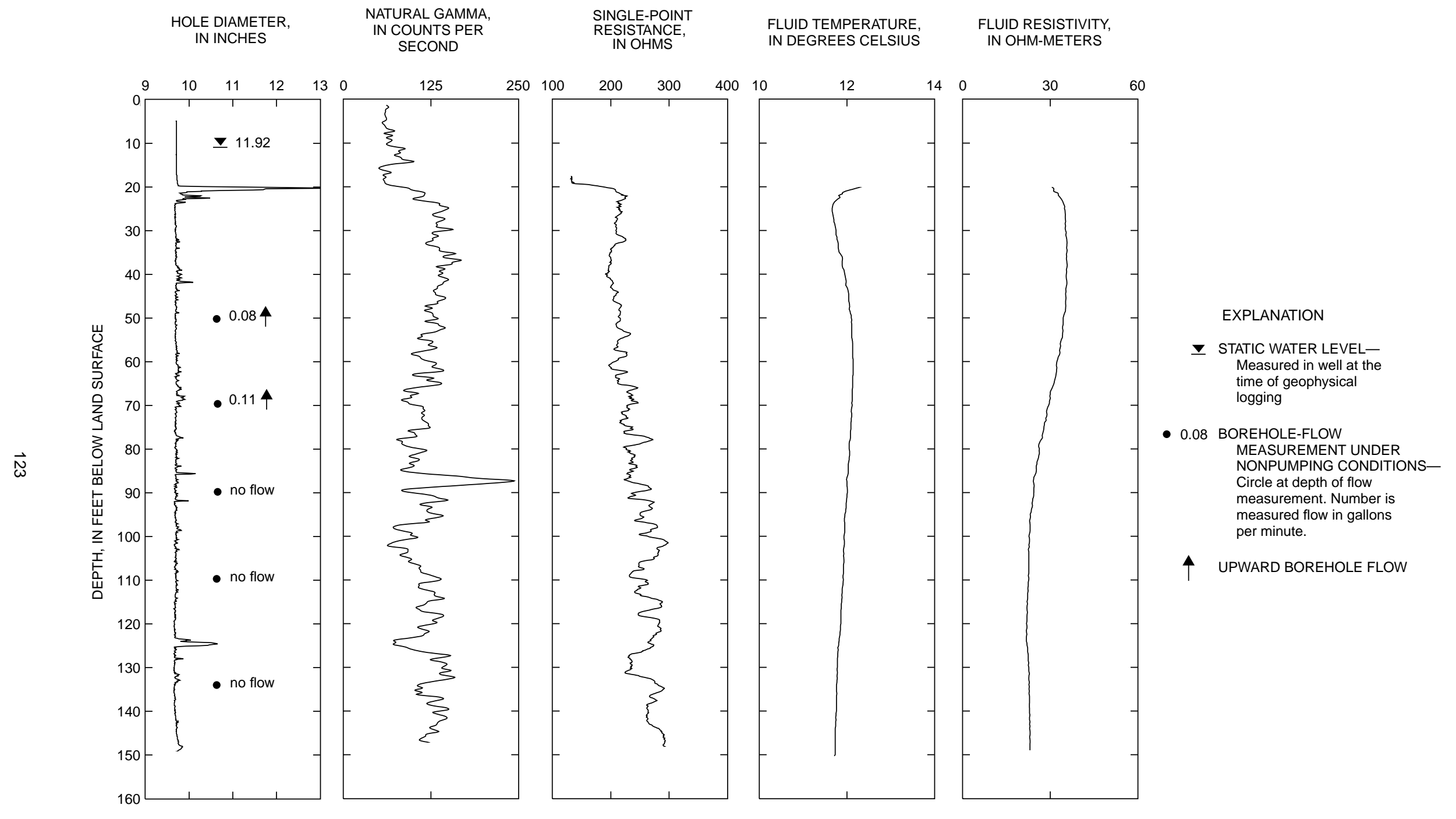

Figure 75. Borehole geophysical logs and direction of nonpumping flow within borehole MG-1619 (Keystone 2I), North Penn Area 6 Superfund Site, Lansdale, Montgomery County, Pennsylvania. 


\section{MG-1620 (Keystone 2S)}

The caliper log shows the total depth of the borehole is $101 \mathrm{ft}$ and it is cased with 6.5-in.-diameter casing to $20 \mathrm{ft}$ bls (fig. 76). The caliper log shows a major fracture at $76 \mathrm{ft}$ bls and numerous minor fractures throughout the open-hole interval. The static water level at the time of logging was $12.15 \mathrm{ft}$ bls. The dipmeter log shows the borehole deviates from vertical approximately $2 \mathrm{ft}$ to the southwest over the total length of the borehole (fig. 77).

The strike and dip of fracture planes was obtained from the acoustic televiewer. The results are shown on an equal-area stereonet with single points (poles) plotted in the lower hemisphere at right angles to the fracture planes. These poles indicate most fracture planes trend approximately northeast-southwest (fig. 78). The greatest concentration of poles are near the center of figure 78 , indicating shallow bedding planes. Eighteen possible bedding planes were identified, 15 planes dip to the northwest with an average strike and dip of N. $78^{\circ}$ E., $6^{\circ}$ NW., which is approximately coincident with regional strike and dip. Three shallow bedding planes dip to the southeast with an average strike and dip of N. $24^{\circ}$ E., $9^{\circ} \mathrm{SE}$. Three highangle fracture planes were identified in the borehole.

The natural-gamma log shows how steel casing (0-20 ft bls) can suppress gamma counts. Elevated gamma readings at $86-88 \mathrm{ft}$ bls indicate a shale unit that may be used for stratigraphic correlation of geologic units with other wells. The fluid-resistivity log shows changes in slope at 20-22, 56, and $85 \mathrm{ft}$ bls that indicate possible water-producing zones. Under nonpumping conditions, the heatpulse flowmeter measured upward borehole flow at $90 \mathrm{ft}$ bls and no flow at 46 and $70 \mathrm{ft}$ bls (table 51). The geophysical logs and the heatpulse-flowmeter measurements indicate water enters the borehole through fractures below $92 \mathrm{ft}$ bls, moves upward, and exits the borehole through the major fracture at $76 \mathrm{ft}$ bls. The driller's log indicates about $50 \mathrm{gal} / \mathrm{min}$ of water is produced at $78 \mathrm{ft}$ bls.

Table 51. Summary of heatpulse-flowmeter measurements for borehole MG-1620 (Keystone 2S) at North Penn Area 6 Superfund Site, Lansdale, Montgomery County, Pennsylvania

[gal/min, gallon per minute]

\begin{tabular}{ccc}
\hline $\begin{array}{c}\text { Depth } \\
\text { (feet below } \\
\text { land surface) }\end{array}$ & $\begin{array}{c}\text { Flow rate } \\
\text { (gal/min) } \\
\text { nonpumping } \\
\text { conditions }\end{array}$ & $\begin{array}{c}\text { Flow direction } \\
\text { nonpumping } \\
\text { conditions }\end{array}$ \\
\hline 46 & no flow & not determined \\
70 & no flow & not determined \\
90 & 0.13 & up \\
\hline
\end{tabular}




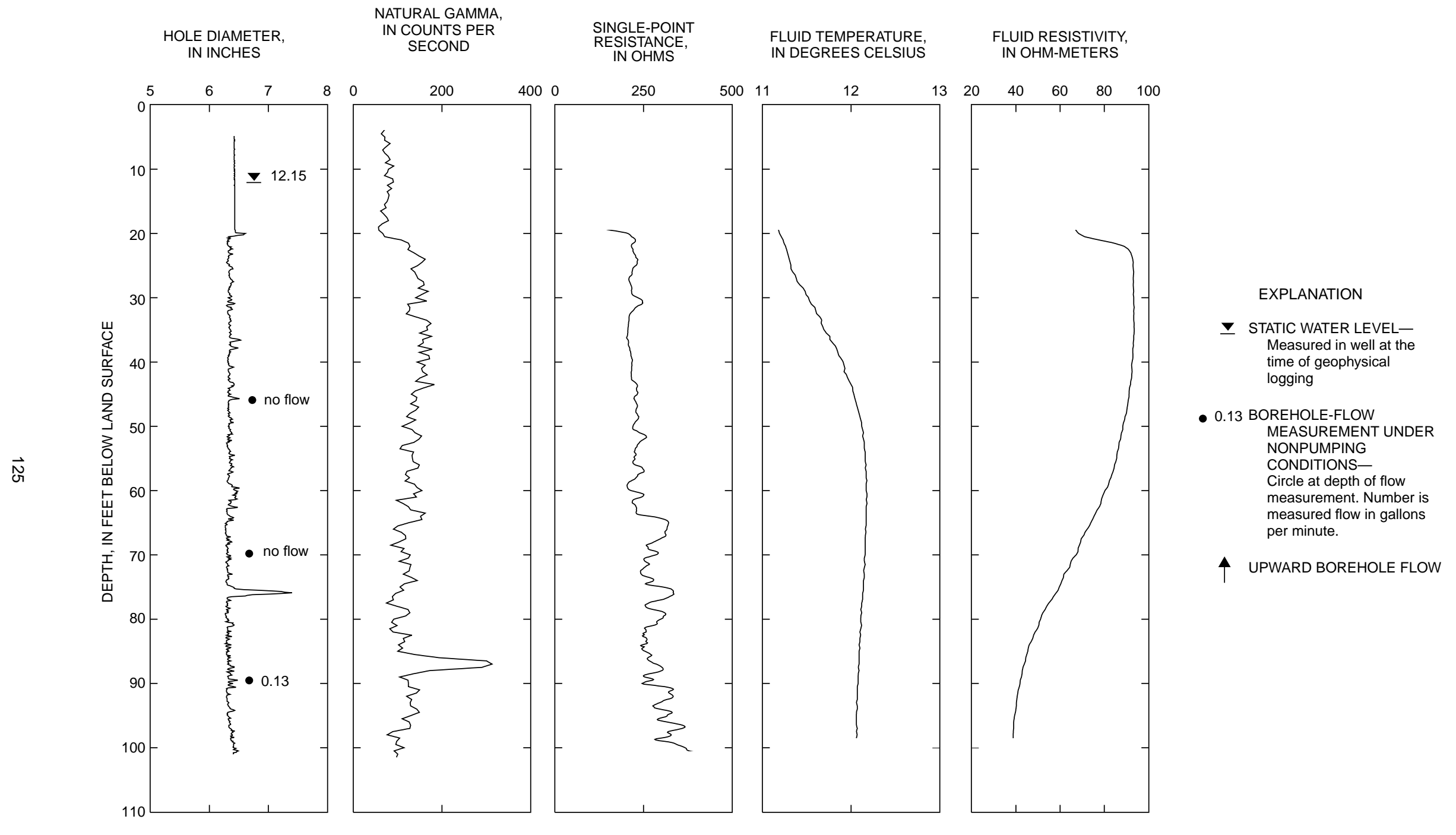

Figure 76. Borehole geophysical logs and direction of nonpumping flow within borehole MG-1620 (Keystone 2S), North Penn Area 6 Superfund Site, Lansdale, Montgomery County, Pennsylvania. 


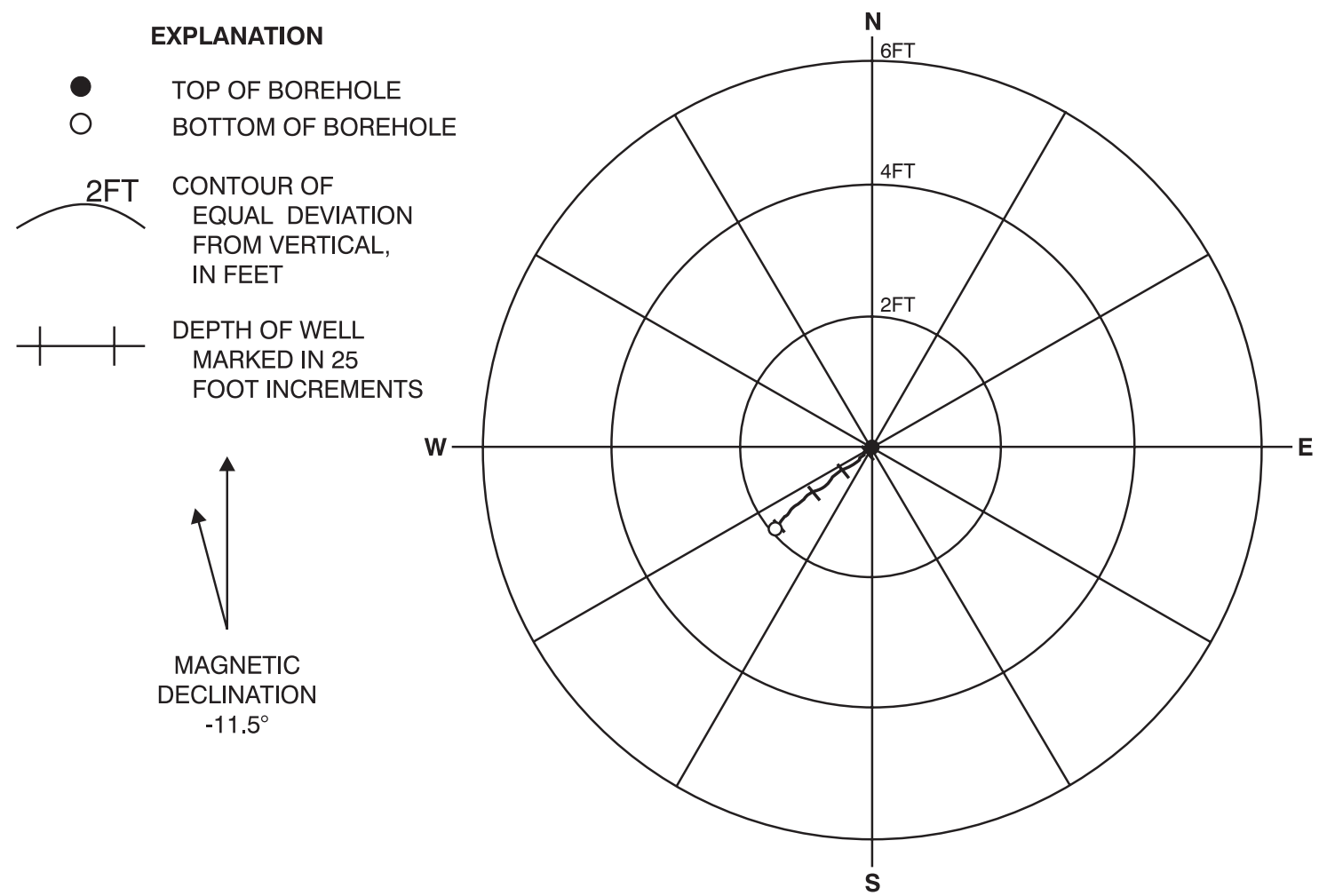

Figure 77. Magnitude and direction of deviation from vertical of borehole MG-1620 (Keystone 2S).

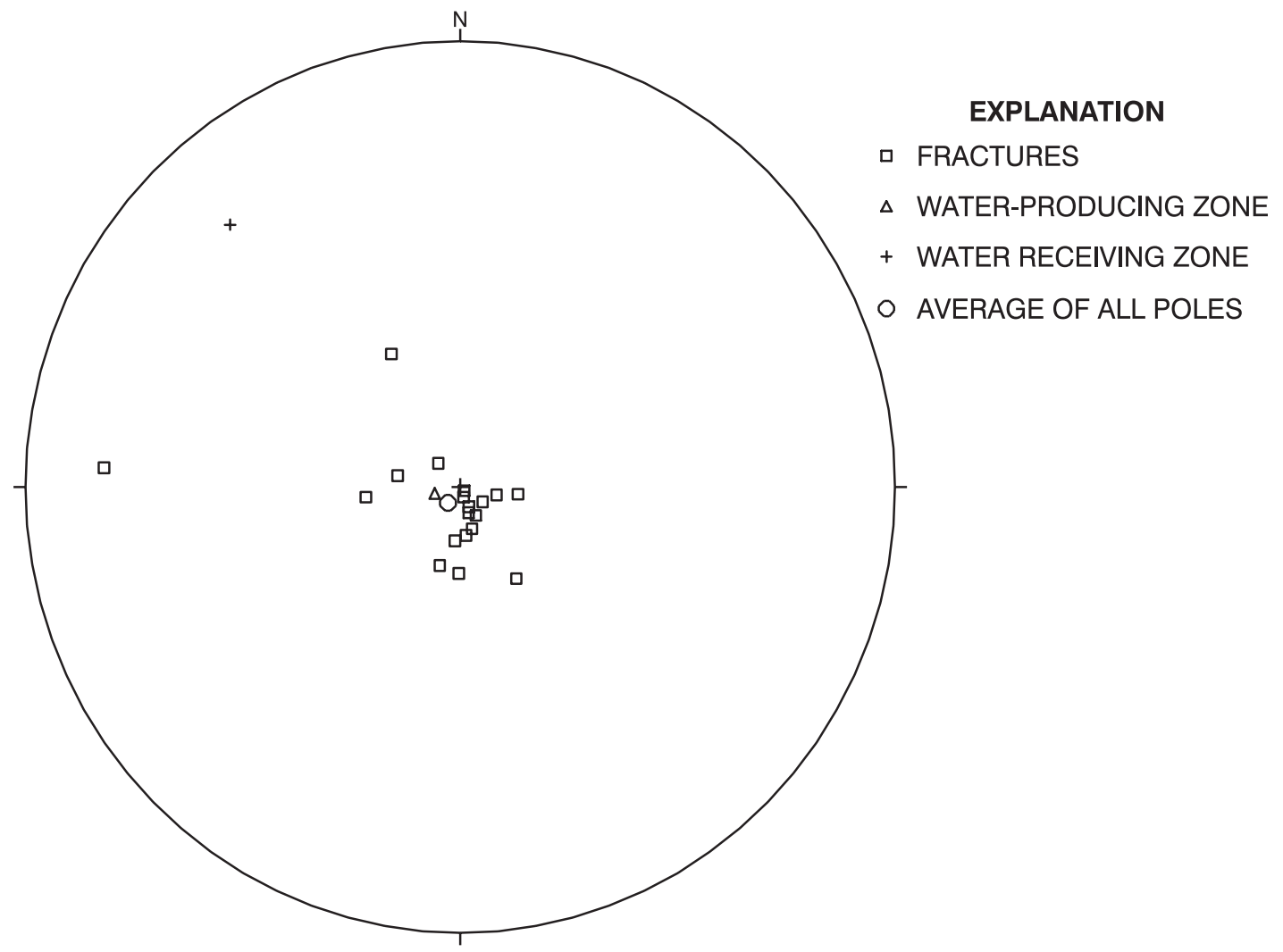

Figure 78. Equal-area lower hemisphere, stereographic projection of poles perpendicular to fracture planes in borehole MG-1620 (Keystone 2S). 


\section{MG-1621 (Royal Cleaners 11)}

The caliper $\log$ shows the total depth of the borehole is $161 \mathrm{ft}$ and it is cased with 10-in.-diameter casing to $18 \mathrm{ft}$ bls at the time of logging (fig. 79). The caliper log shows major fractures at 18.5, 53, 58-59, 62-65, and 74-77 ft bls; constrictions at 57 and $61 \mathrm{ft}$ bls; plus numerous minor fractures throughout the open-hole interval. The static water level at the time of logging was $50.48 \mathrm{ft}$ bls. The fluid-resistivity log shows changes in slope at 52-68, 96, 116, and $134 \mathrm{ft}$ bls that indicate possible water-producing zones. The fluid-temperature $\log$ shows a major deflection in slope at $60 \mathrm{ft}$ bls that may be the result of the borehole constriction. Another deflection in slope occurs at 74-77 ft bls that corresponds to a major fracture seen on the caliper log. Under nonpumping conditions, the heatpulse flowmeter measured upward borehole flow at 80, 110, 128, and $150 \mathrm{ft}$ bls (table 52). The geophysical logs and the heatpulse-flowmeter measurements indicate water enters the borehole through fractures at 96, 114, 134, and below $150 \mathrm{ft}$ bls, moves upward, and exits the borehole through fractures at $50-68 \mathrm{ft}$ bls. The driller's $\log$ indicates about $50 \mathrm{gal} / \mathrm{min}$ of water is produced at about $140 \mathrm{ft}$ bls.

Table 52. Summary of heatpulse-flowmeter measurements for borehole MG-1621 (Royal Cleaners 1I) at North Penn Area 6 Superfund Site, Lansdale, Montgomery County, Pennsylvania [gal/min, gallon per minute]

\begin{tabular}{ccc}
\hline $\begin{array}{c}\text { Depth } \\
\text { (feet below } \\
\text { land surface) }\end{array}$ & $\begin{array}{c}\text { Flow rate } \\
\text { (gal/min) } \\
\text { nonpumping } \\
\text { conditions }\end{array}$ & $\begin{array}{c}\text { Flow direction } \\
\text { nonpumping } \\
\text { conditions }\end{array}$ \\
\hline 80 & 0.46 & up \\
110 & .34 & up \\
128 & .21 & up \\
150 & .08 & up \\
\hline
\end{tabular}




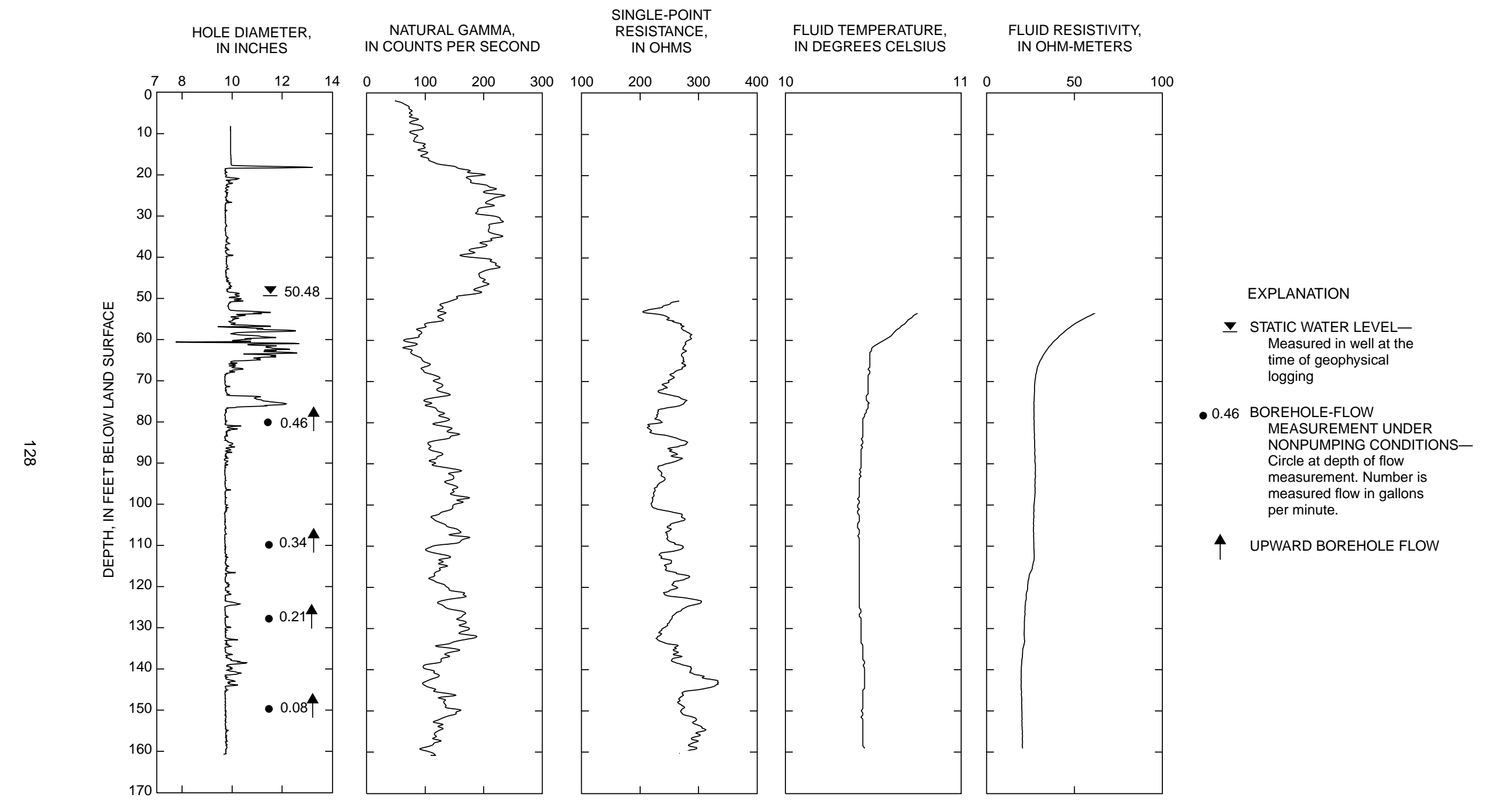

Figure 79. Borehole geophysical logs and direction of nonpumping flow within borehole MG-1621 (Royal Cleaners 1I), North Penn Area 6 Superfund Site, Lansdale, Montgomery County, Pennsylvania. 


\section{MG-1622 (Lansdale Warehouse 1S)}

The caliper log shows the total depth of the borehole is $101 \mathrm{ft}$ and it is cased with 6.25-in.-diameter casing to $20 \mathrm{ft}$ bls (fig. 80). The caliper log shows only minor fractures throughout the open-hole interval and a reduction in borehole diameter to $5.75 \mathrm{in}$. at $79 \mathrm{ft}$ bls. The static water level at the time of logging was $50.37 \mathrm{ft}$ bls. The fluid-resistivity log shows a change in slope at $52-68 \mathrm{ft}$ bls. Under nonpumping conditions, the heatpulse flowmeter measured upward borehole flow at $86 \mathrm{ft} \mathrm{bls}$ and no flow at $63 \mathrm{ft}$ bls (table 53). The geophysical logs and the heatpulse-flowmeter measurements indicate water enters the borehole through fractures below $86 \mathrm{ft}$ bls, moves upward, and exits the borehole through fractures between 70-74 ft bls.

Table 53. Summary of heatpulse-flowmeter measurements for borehole MG-1622 (Lansdale Warehouse 1S) at North Penn Area 6 Superfund Site, Lansdale, Montgomery County, Pennsylvania [gal/min, gallon per minute]

\begin{tabular}{ccc}
\hline $\begin{array}{c}\text { Depth } \\
\text { (feet below } \\
\text { land surface) }\end{array}$ & $\begin{array}{c}\text { Flow rate } \\
\text { (gal/min) } \\
\text { nonpumping } \\
\text { conditions }\end{array}$ & $\begin{array}{c}\text { Flow direction } \\
\text { nonpumping } \\
\text { conditions }\end{array}$ \\
\hline 63 & no flow & not determined \\
86 & 0.08 & up \\
\hline
\end{tabular}



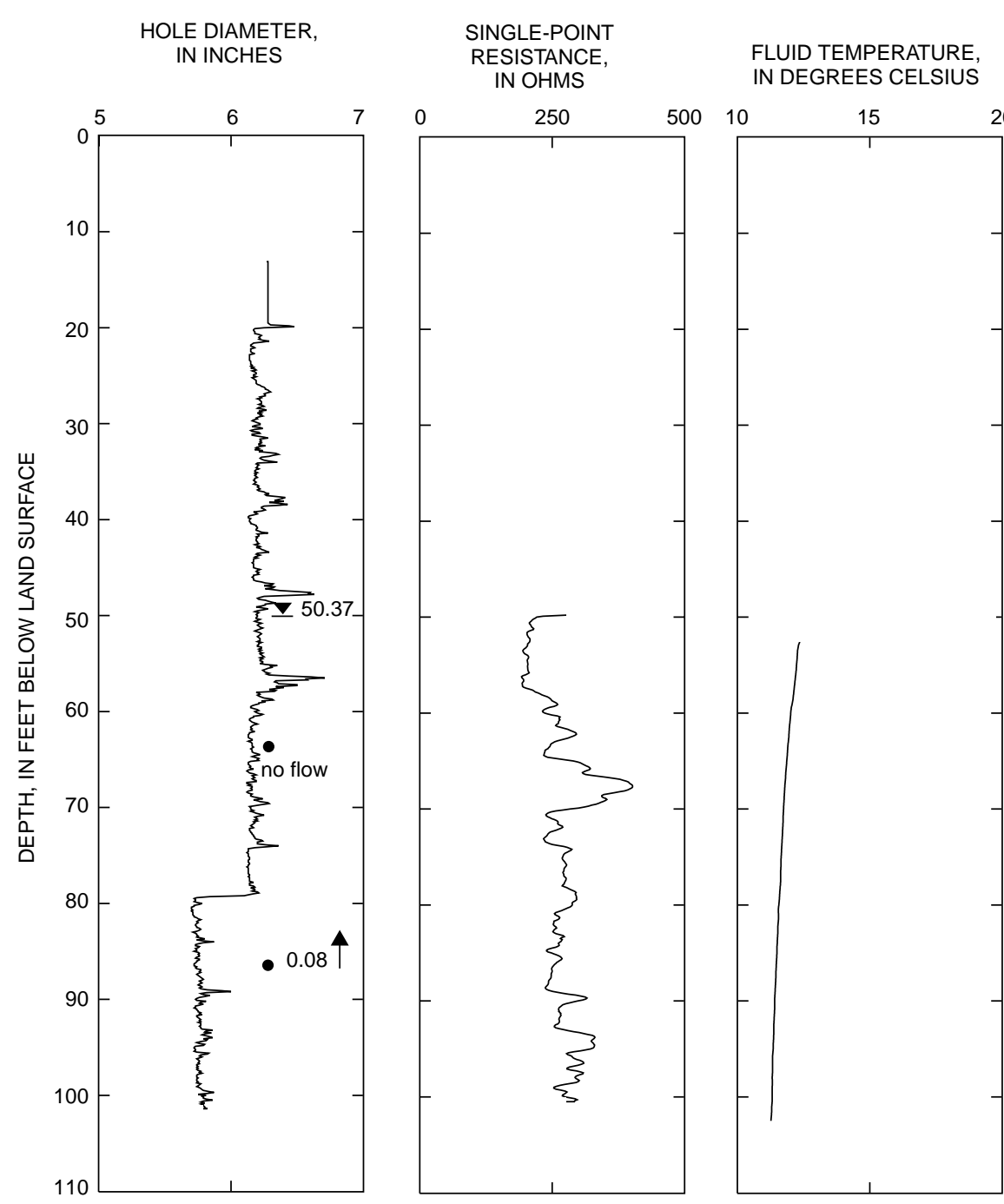

FLUID RESISTIVITY,

$\begin{array}{ll}500 & 10\end{array}$

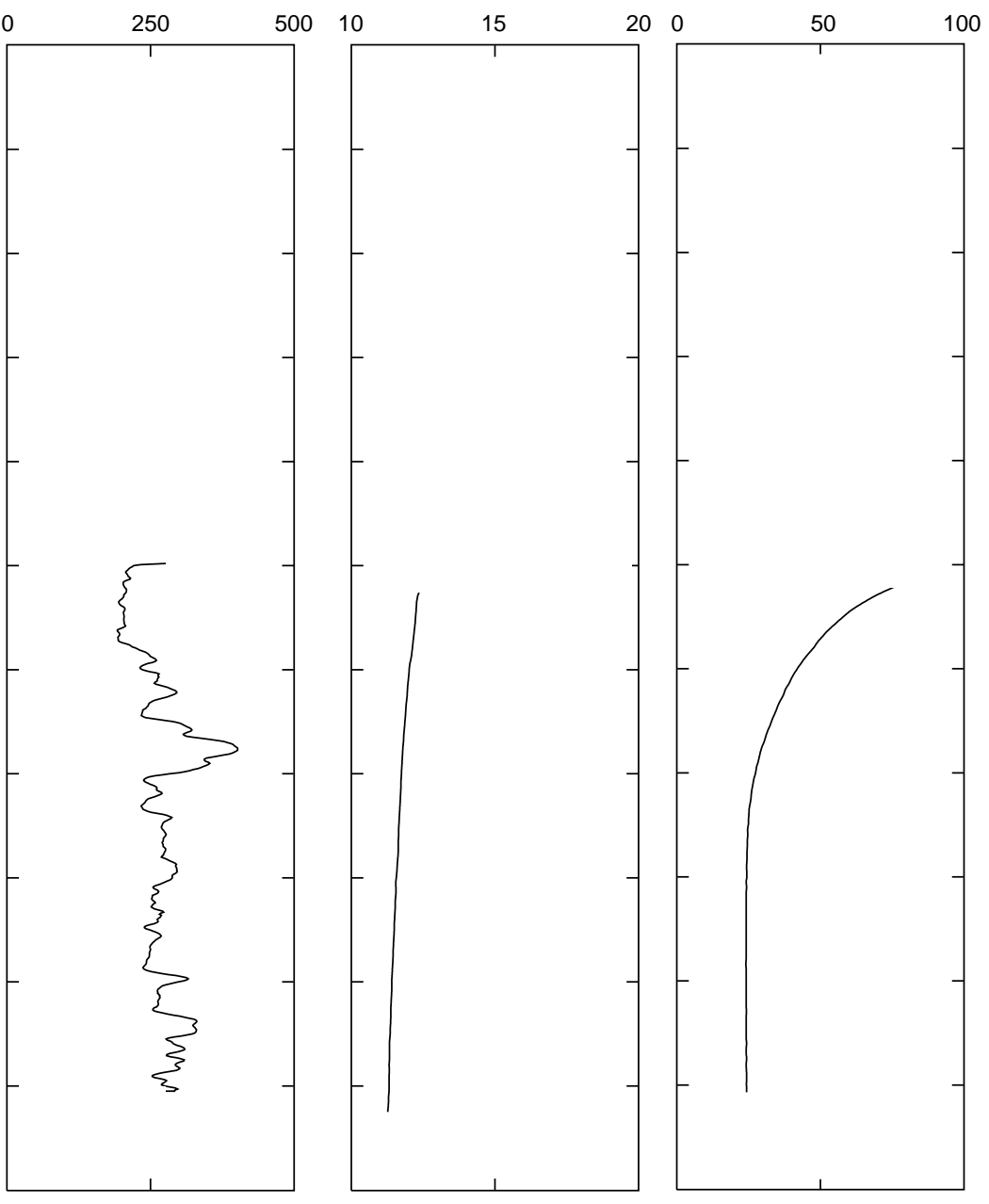

$\begin{array}{lll}20 & 0\end{array}$

100

EXPLANATION

- STATIC WATER LEVEL-

Measured in well at the

time of geophysical

logging

- 0.08 BOREHOLE-FLOW MEASUREMENT UNDER
NONPUMPING CONDITIONSCircle at depth of flow measurement. Number is measured flow in gallons per minute.

个 uPWARD BOREHOLE FLOW

Figure 80. Borehole geophysical logs and direction of nonpumping flow within borehole MG-1622 (Lansdale Warehouse 1S), North Penn Area 6 Superfund Site, Lansdale, Montgomery County, Pennsylvania. 


\section{MG-1623 (Royal Cleaners 1S)}

The caliper log shows the total depth of the borehole is $101 \mathrm{ft}$ and it is cased with 6.5-in.-diameter casing to $20 \mathrm{ft}$ bls (fig. 81). The caliper log shows a major fracture at $21 \mathrm{ft}$ bls plus numerous minor fractures at 54-61, 68-72, 74-75, and $83 \mathrm{ft}$ bls. The static water level at the time of logging was $48.95 \mathrm{ft}$ bls. The naturalgamma log shows, from 2-20 ft bls, the suppression of gamma counts by the steel casing. The fluidresistivity log shows a change in slope at $75 \mathrm{ft}$ bls that may be a water-producing zone. The fluidtemperature log shows a deflection in slope at $67 \mathrm{ft}$ bls that closely corresponds to minor fractures at 68$72 \mathrm{ft}$ bls. Under nonpumping conditions, the heatpulse flowmeter measured upward borehole flow at 64, 78, and $92 \mathrm{ft}$ (table 54). The geophysical logs and the heatpulse-flowmeter measurements indicate water enters the borehole through fractures below $92 \mathrm{ft}$ bls, moves upward, and exits the borehole through fractures at 50-62 ft bls.

Table 54. Summary of heatpulse-flowmeter measurements for borehole MG-1623 (Royal Cleaners 1S) at North Penn Area 6 Superfund Site, Lansdale, Montgomery County, Pennsylvania

[gal/min, gallon per minute]

\begin{tabular}{ccc}
\hline $\begin{array}{c}\text { Depth } \\
\text { (feet below } \\
\text { land surface) }\end{array}$ & $\begin{array}{c}\text { Flow rate } \\
\text { (gal/min) } \\
\text { nonpumping } \\
\text { conditions }\end{array}$ & $\begin{array}{c}\text { Flow direction } \\
\text { nonpumping } \\
\text { conditions }\end{array}$ \\
\hline 64 & 0.13 & up \\
78 & .09 & up \\
92 & .12 & up \\
\hline
\end{tabular}




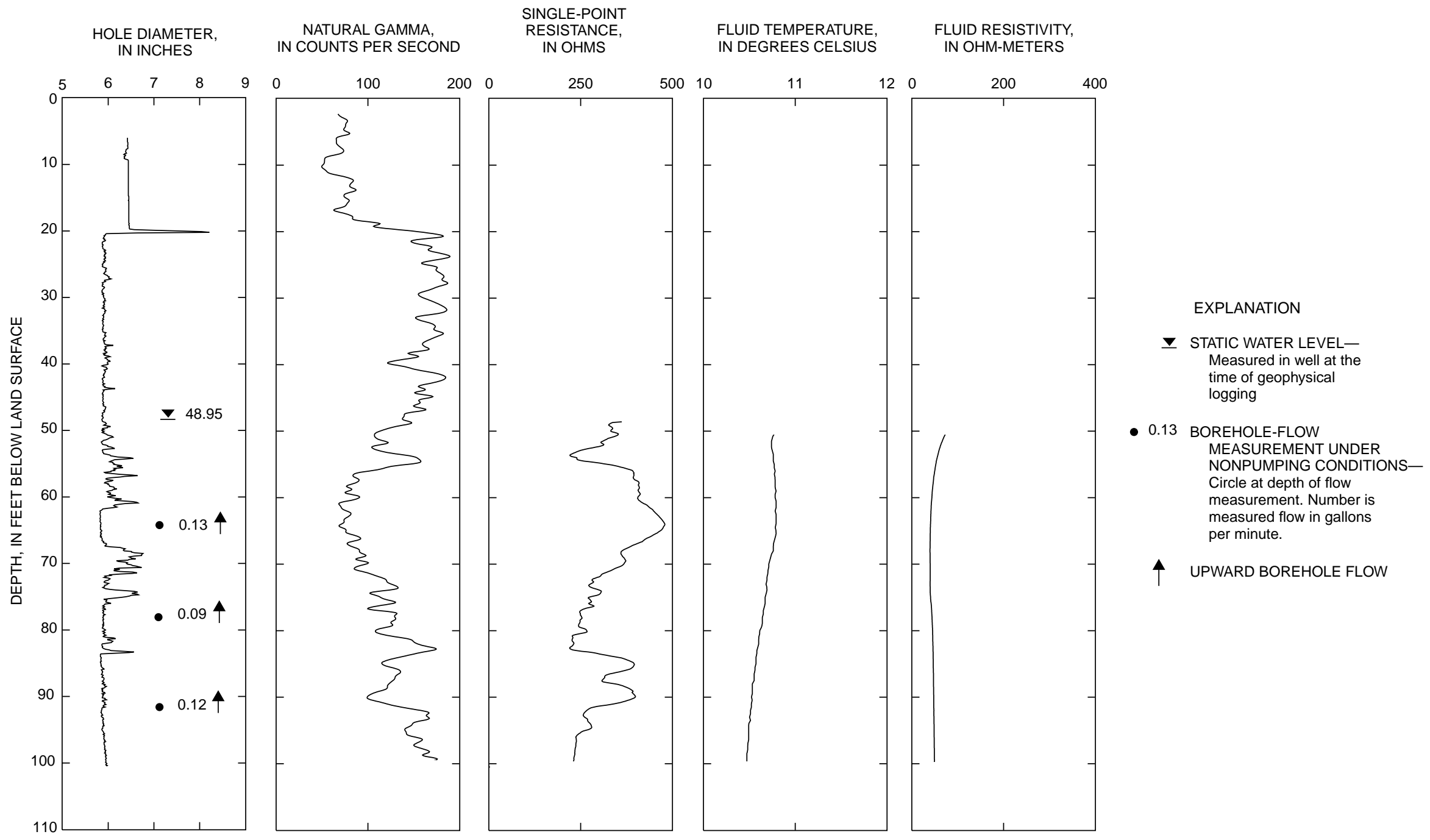

Figure 81. Borehole geophysical logs and direction of nonpumping flow within borehole MG-1623 (Royal Cleaners 1S), North Penn Area 6 Superfund Site, Lansdale, Montgomery County, Pennsylvania. 


\section{MG-1624 (Evans 1S)}

The caliper log shows the total depth of the borehole is $101 \mathrm{ft}$ and it is cased with 6.25-in.-diameter casing to $18.5 \mathrm{ft}$ bls (fig. 82). The caliper log shows major fractures at 19-20 and 55-57 ft bls plus other minor fractures throughout the open-hole interval. The static water level at the time of logging was $38.66 \mathrm{ft}$ bls. The natural-gamma log shows shale units with elevated gamma readings at $25-27$ and $63-66 \mathrm{ft}$ bls that might be used for stratigraphic correlation of geologic units with other wells. The fluid-temperature log shows a change in slope at $90 \mathrm{ft}$ bls that correlates with a water-producing zone reported on the driller's $\log$. The driller's log indicates water-producing zones between $70-90 \mathrm{ft}$ bls; the greatest production is between $80-90 \mathrm{ft}$ bls. Under nonpumping conditions, the heatpulse flowmeter measured no borehole flow at $48,60,76$, and $90 \mathrm{ft}$ bls (table 55).

Table 55. Summary of heatpulse-flowmeter measurements for borehole MG-1624 (Evans 1S) at North Penn Area 6 Superfund Site, Lansdale, Montgomery County, Pennsylvania

[gal/min, gallon per minute]

\begin{tabular}{ccc}
\hline $\begin{array}{c}\text { Depth } \\
\text { feet below } \\
\text { land surface) }\end{array}$ & $\begin{array}{c}\text { Flow rate } \\
\text { (gal/min) } \\
\text { nonpumping } \\
\text { conditions }\end{array}$ & $\begin{array}{c}\text { Flow direction } \\
\text { nonpumping } \\
\text { conditions }\end{array}$ \\
\hline 48 & no flow & not determined \\
60 & no flow & not determined \\
76 & no flow & not determined \\
90 & no flow & not determined \\
\hline
\end{tabular}




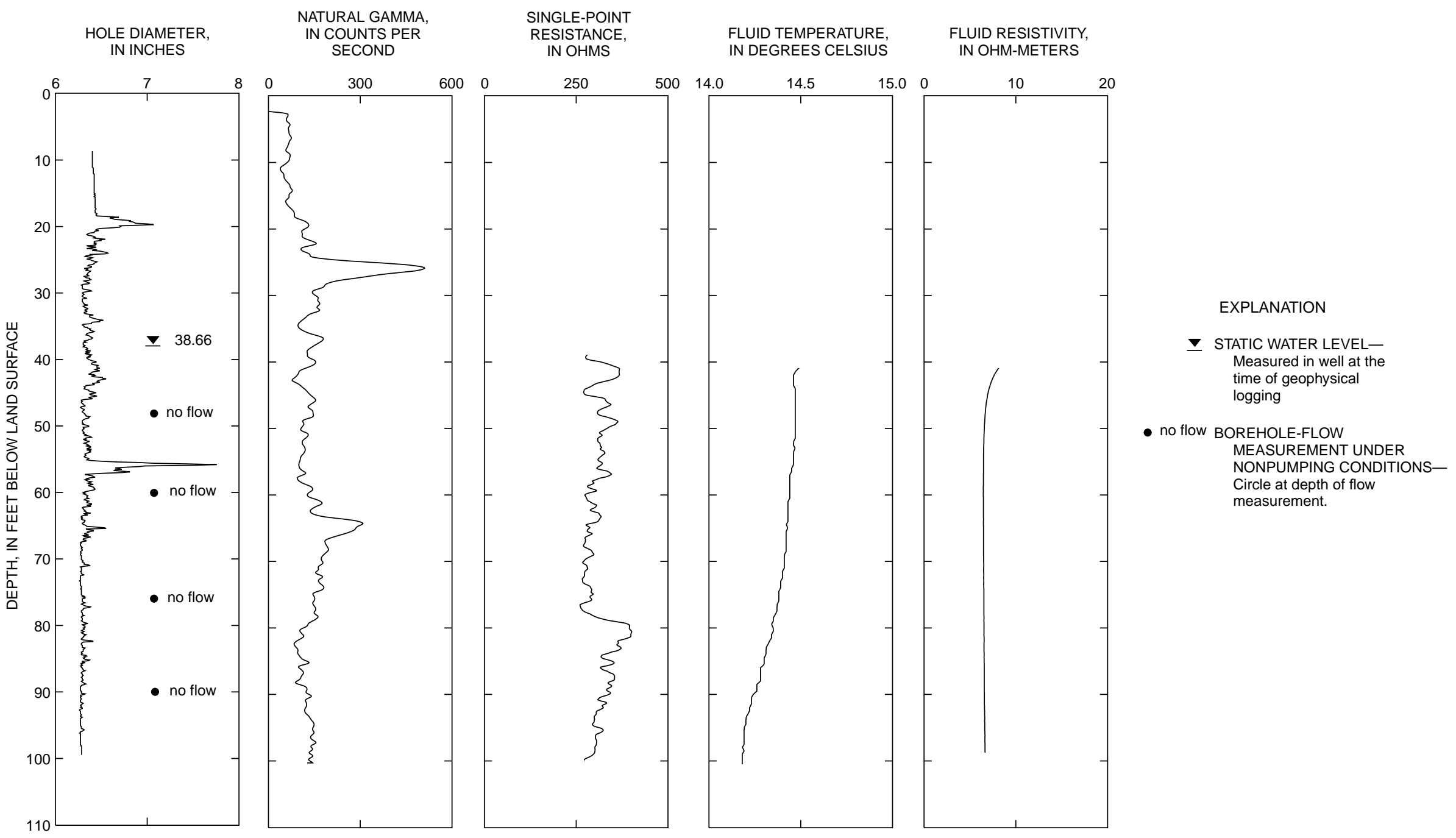

Figure 82. Borehole geophysical logs and direction of nonpumping flow within borehole MG-1624 (Evans 1S), North Penn Area 6 Superfund Site, Lansdale, Montgomery County, Pennsylvania. 


\section{MG-1639 (Rex 31)}

The caliper log shows the total depth of the borehole is $149 \mathrm{ft}$ and it is cased with 10-in.-diameter casing to $19 \mathrm{ft}$ bls at the time of logging (fig. 83). The caliper log shows major fractures at 20, 25-39, and 88-93 ft bls plus minor fractures throughout the open-hole interval. The static water level at the time of logging was $24.68 \mathrm{ft}$ bls. The fluid-resistivity log shows changes in slope at 28, 34, 38, and near $112 \mathrm{ft}$ bls that correlate with fractures shown on the caliper log. The fluid-temperature log also shows changes in slope at 31,38 , and $112 \mathrm{ft}$ bls. Fractures near 31 and $38 \mathrm{ft}$ bls are water-producing zones and the fracture near $112 \mathrm{ft}$ bls is a water-receiving zone. Under nonpumping conditions, the heatpulse flowmeter measured downward borehole flow at 42, 56, and $100 \mathrm{ft}$ bls and no flow at $120 \mathrm{ft}$ bls (table 56). The geophysical logs and the heatpulse-flowmeter measurements indicate water enters the borehole through fractures at 30-38 ft bls, moves downward, and exits the borehole through fractures at 102-113 ft bls. Downward flow may be induced by the on-site production well that pumps continuously.

Table 56. Summary of heatpulse-flowmeter measurements for borehole MG-1639 (Rex 3I) at North Penn Area 6 Superfund Site, Lansdale, Montgomery County, Pennsy/vania

[gal/min, gallon per minute]

\begin{tabular}{ccc}
\hline $\begin{array}{c}\text { Depth } \\
\text { (feet below } \\
\text { land surface) }\end{array}$ & $\begin{array}{c}\text { Flow rate } \\
\text { (gal/min) } \\
\text { nonpumping } \\
\text { conditions }\end{array}$ & $\begin{array}{c}\text { Flow direction } \\
\text { nonpumping } \\
\text { conditions }\end{array}$ \\
\hline 42 & 1.3 & down \\
56 & 1.3 & down \\
100 & 1.1 & down \\
120 & no flow & not determined \\
\hline
\end{tabular}



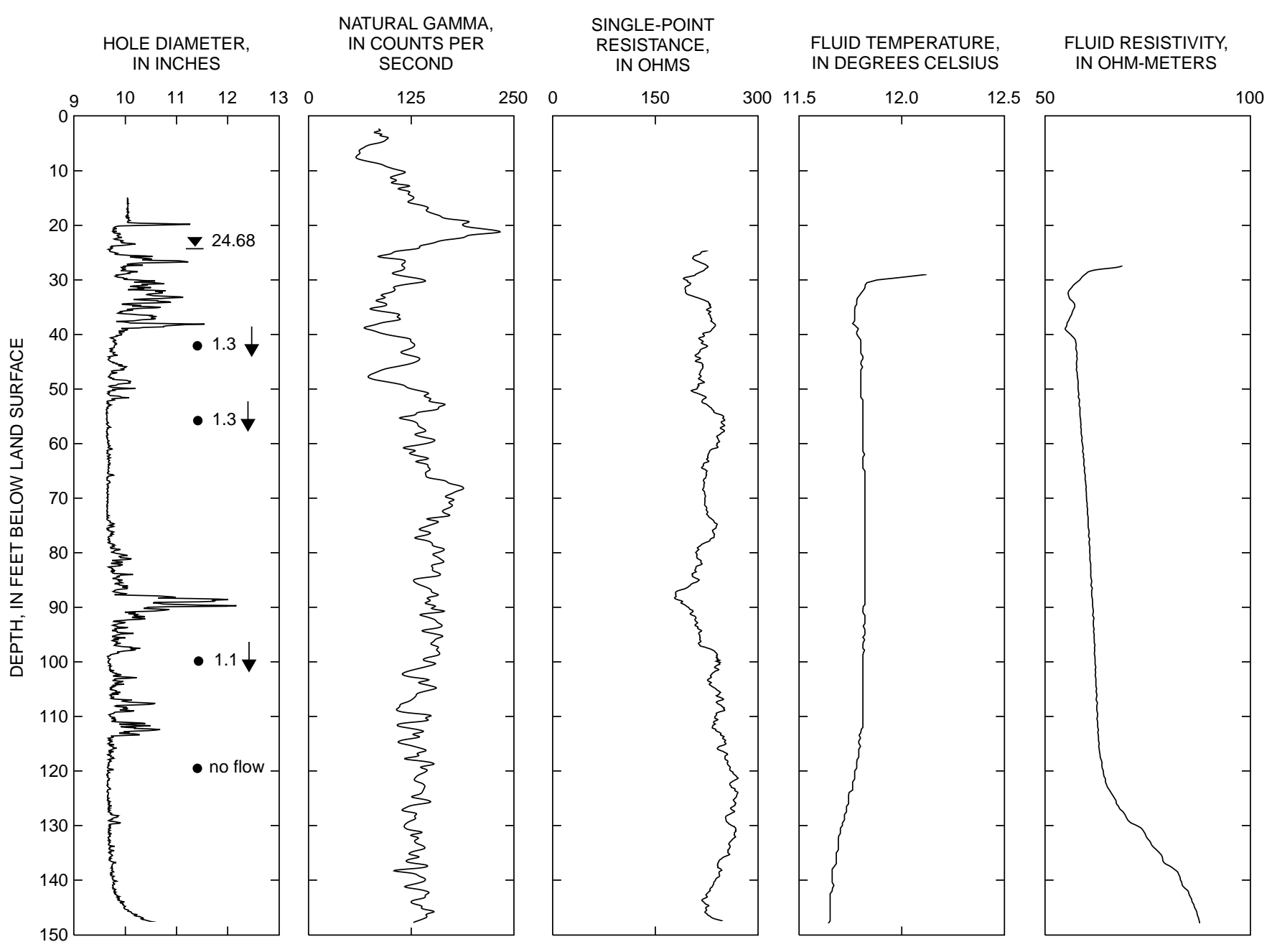

EXPLANATION

₹ STATIC WATER LEVEL-

Measured in well at the time of geophysical

logging

- 1.3 BOREHOLE-FLOW MEASUREMENT UNDER NONPUMPING

CONDITIONS-

Circle at depth of flow

measurement. Number is

measured flow in gallons

per minute.

$\downarrow$ DOWNWARD BOREHOLE FLOW

Figure 83. Borehole geophysical logs and direction of nonpumping flow within borehole MG-1639 (Rex 3I), North Penn Area 6 Superfund Site, Lansdale, Montgomery County, Pennsylvania. 


\section{MG-1640 (Rex 3S)}

The caliper log shows the total depth of the borehole is $66 \mathrm{ft}$ and it is cased with 6.5-in.-diameter casing to $23 \mathrm{ft}$ bls (fig. 84). The caliper log shows major fractures at 23 and $30 \mathrm{ft}$ bls plus numerous minor fractures throughout the open-hole interval. The static water level at the time of logging was $23.33 \mathrm{ft}$ bls. The fluidresistivity log shows a change in slope at 23-30 ft bls that correlates to fractures shown on the caliper log. The fluid-temperature log shows a change in slope at $43 \mathrm{ft}$ bls that indicates a water-producing zone. Under nonpumping conditions, the heatpulse flowmeter measured upward borehole flow at 27 and $40 \mathrm{ft}$ bls and no flow at $50 \mathrm{ft}$ bls (table 57). The geophysical logs and the heatpulse-flowmeter measurements indicate water enters the borehole through fractures at $43 \mathrm{ft}$ bls, moves upward, and exits the borehole through fractures at 23 and $30 \mathrm{ft}$ bls.

Table 57. Summary of heatpulse-flowmeter measurements for borehole MG-1640 (Rex 3S) at North Penn Area 6 Superfund Site, Lansdale, Montgomery County, Pennsylvania

[gal/min, gallon per minute]

\begin{tabular}{ccc}
\hline $\begin{array}{c}\text { Depth } \\
\text { (feet below } \\
\text { land surface) }\end{array}$ & $\begin{array}{c}\text { Flow rate } \\
\text { (gal/min) } \\
\text { nonpumping } \\
\text { conditions }\end{array}$ & $\begin{array}{c}\text { Flow direction } \\
\text { nonpumping } \\
\text { conditions }\end{array}$ \\
\hline 27 & 0.06 & up \\
40 & .09 & up \\
50 & no flow & not determined \\
\hline
\end{tabular}




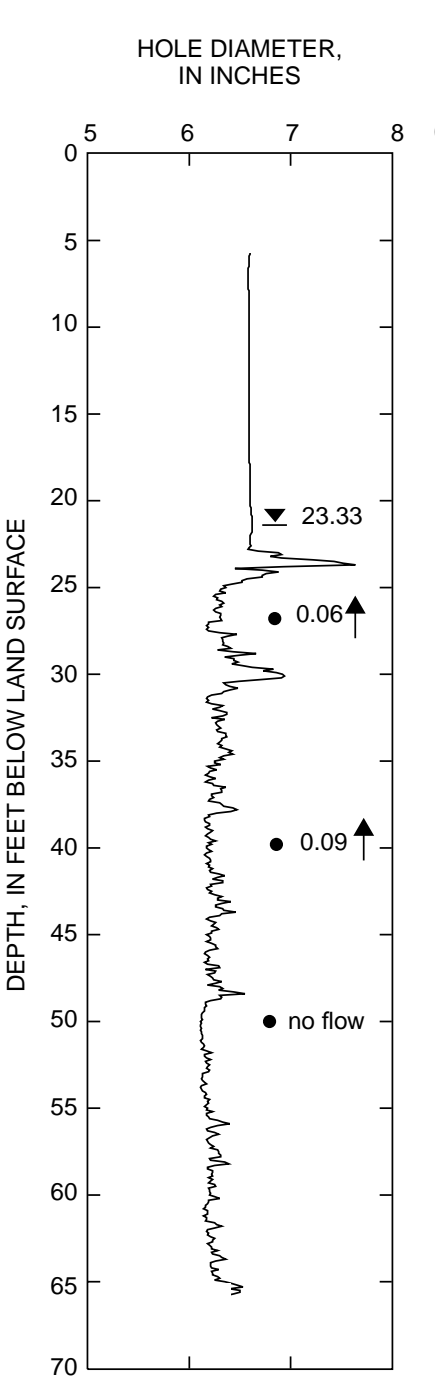

NATURAL GAMMA,
IN COUNTS PER

SECOND
SECONT PER
SINGLE-POINT RESISTANCE,

FLUID TEMPERATURE,

IN DEGREES CELSIUS

FLUID RESISTIVITY,

N OHM-METERS
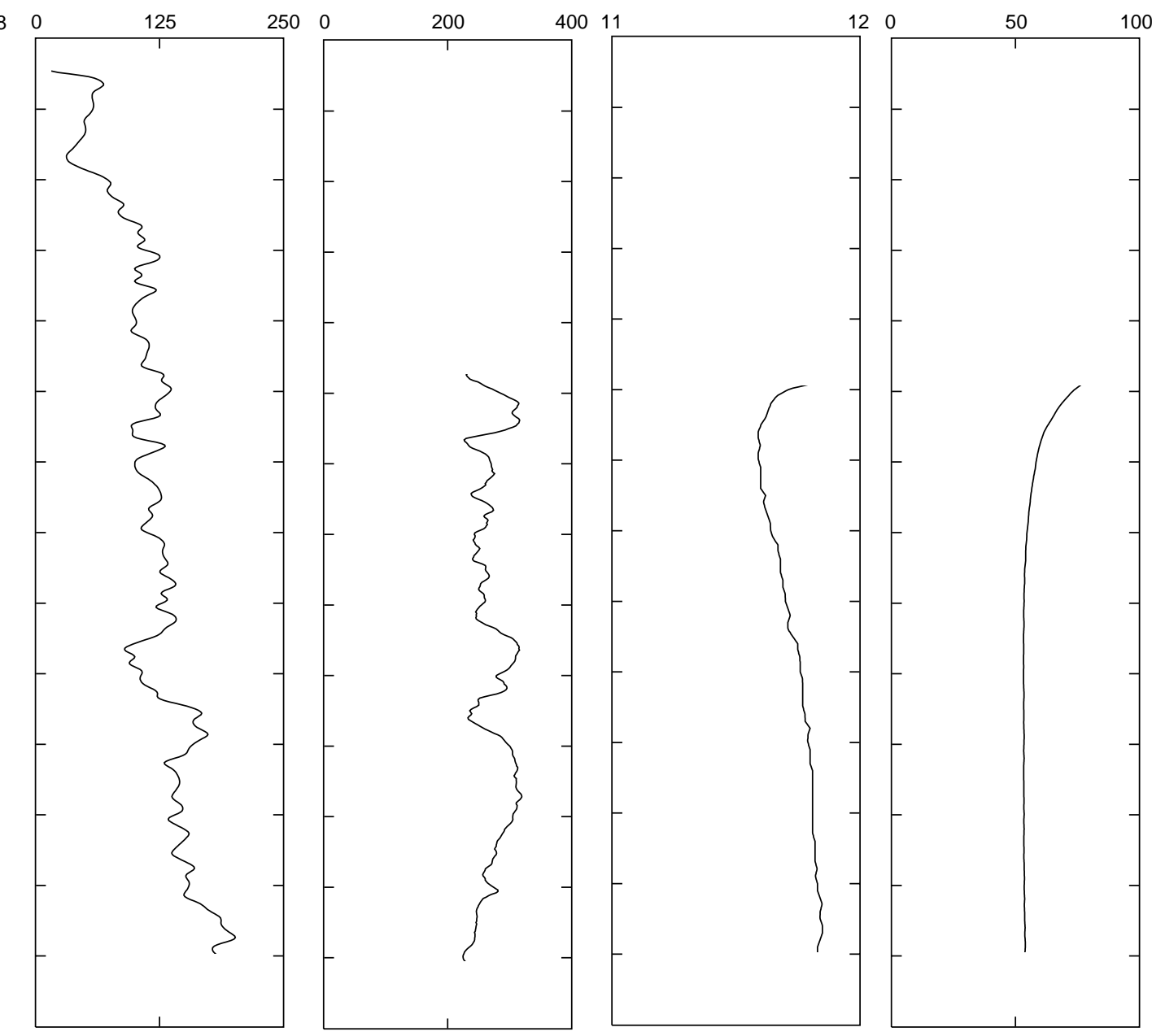

\section{EXPLANATION}

$\checkmark$ STATIC WATER LEVELMeasured in well at the time of geophysical

logging

- 0.06 BOREHOLE-FLOW

MEASUREMENT UNDER NONPUMPING CONDITIONS-

Circle at depth of flow

measurement. Number is

measured flow in gallons per minute.

个 UPWARD BOREHOLE FLOW

Figure 84. Borehole geophysical logs and direction of nonpumping flow within borehole MG-1640 (Rex 3S), North Penn Area 6 Superfund Site, Lansdale, Montgomery County, Pennsylvania. 


\section{MG-1641 (Rex 1S)}

The caliper log shows the total depth of the borehole is $50 \mathrm{ft}$ and it is cased with 6.5-in.- diameter casing to $18 \mathrm{ft}$ bls (fig. 85). The caliper log shows major fractures at 33, 36-37, 38.5, and $41 \mathrm{ft}$ bls. The static water level at the time of logging was $22.48 \mathrm{ft}$ bls. The fluid-resistivity log shows a change in slope at $37 \mathrm{ft}$ bls that correlates to a fracture shown on the caliper log that may indicate a water-producing zone. The fluidtemperature log shows changes in slope at 28 and $42 \mathrm{ft}$ bls that also may indicate water-producing zones. No heatpulse-flowmeter measurements were made in the well.

\section{CORRELATION OF NATURAL-GAMMA LOGS}

Stratigraphic correlation between wells at the NP6 Superfund Site was done using elevated naturalgamma readings associated with thin shale beds. The elevated gamma readings are generally from 2 to more than 10 times greater than readings for other parts of the borehole. The orientation of these shale marker beds at several locations in Lansdale was determined by calculating the strike and dip of elevated natural-gamma readings (spikes) from logs for sets of three wells. The locations of wells used in correlations are shown with cross-sections in figure 1 . Natural-gamma spikes associated with the radioactive shale marker beds can be correlated at distances of 5,000 ft or greater along strike. Regional correlation in the dip direction, however, is limited to less than 3,000 ft because at that distance, well depths typically are not great enough to penetrate the marker beds estimated to dip at an angle of about $11^{\circ}$.

The orientation of the marker beds intersected by wells south of the center of Lansdale are correlated on cross-section A-A' (figs. 1, 86). Elevated natural-gamma readings in logs for wells MG-1600, MG-1444, MG-1602, MG-1603, MG-1605, and MG-1604 were correlated. At this location, the beds strike about N. $43^{\circ}$ E., and dip about $10^{\circ}$ NW. Near the center of Lansdale, natural-gamma logs for wells MG-81, MG-1612, MG-1614, MG-1608, and MG-618 were correlated as shown in the cross-section B-B' (figs. 1, 87). The strike in this area is about N. $47^{\circ}$ E., with a dip of about $12^{\circ} \mathrm{NW}$. 


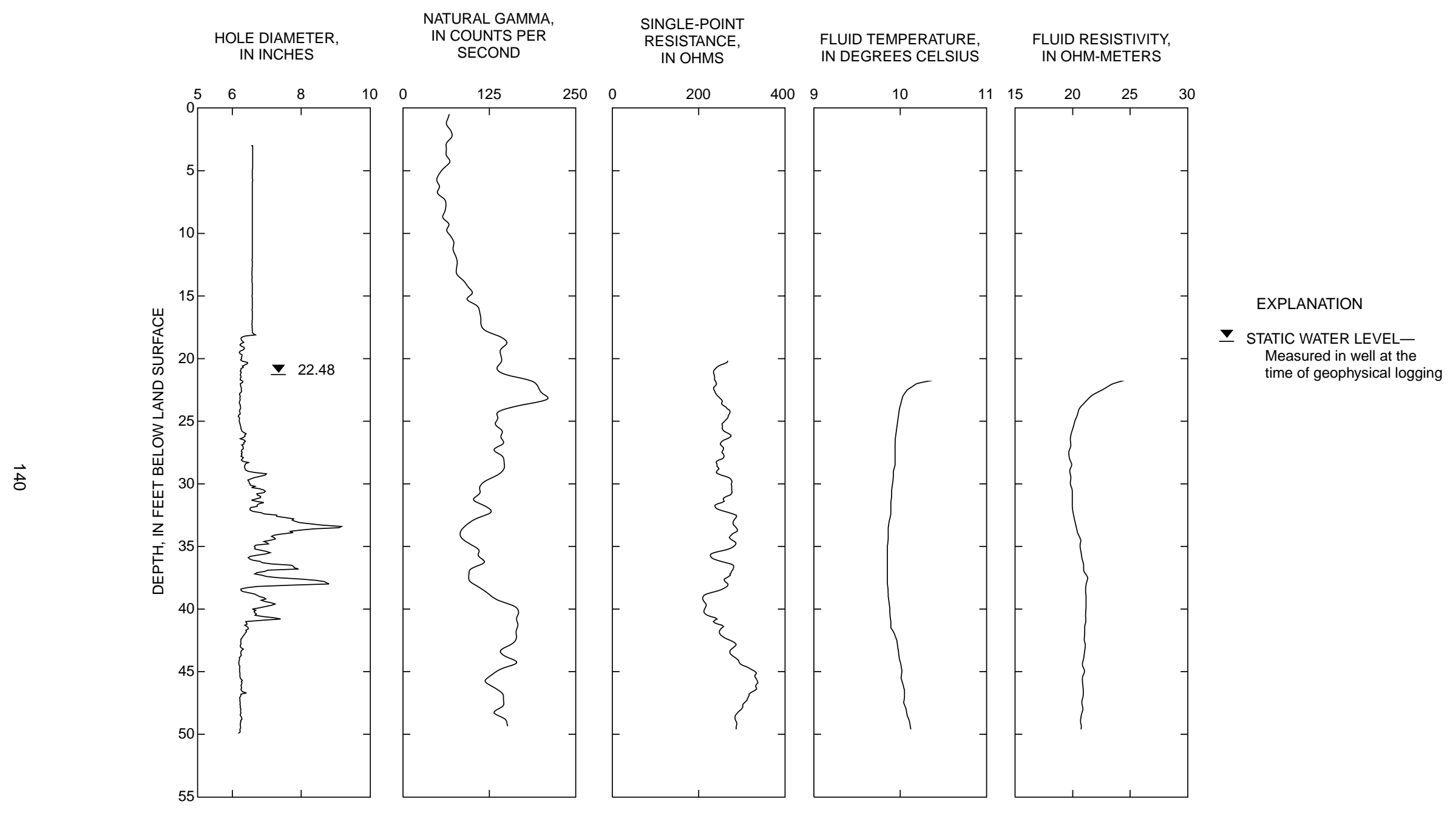

Figure 85. Borehole geophysical logs for borehole MG-1641 (Rex 1S), North Penn Area 6 Superfund Site, Lansdale, Montgomery County, Pennsylvania. 


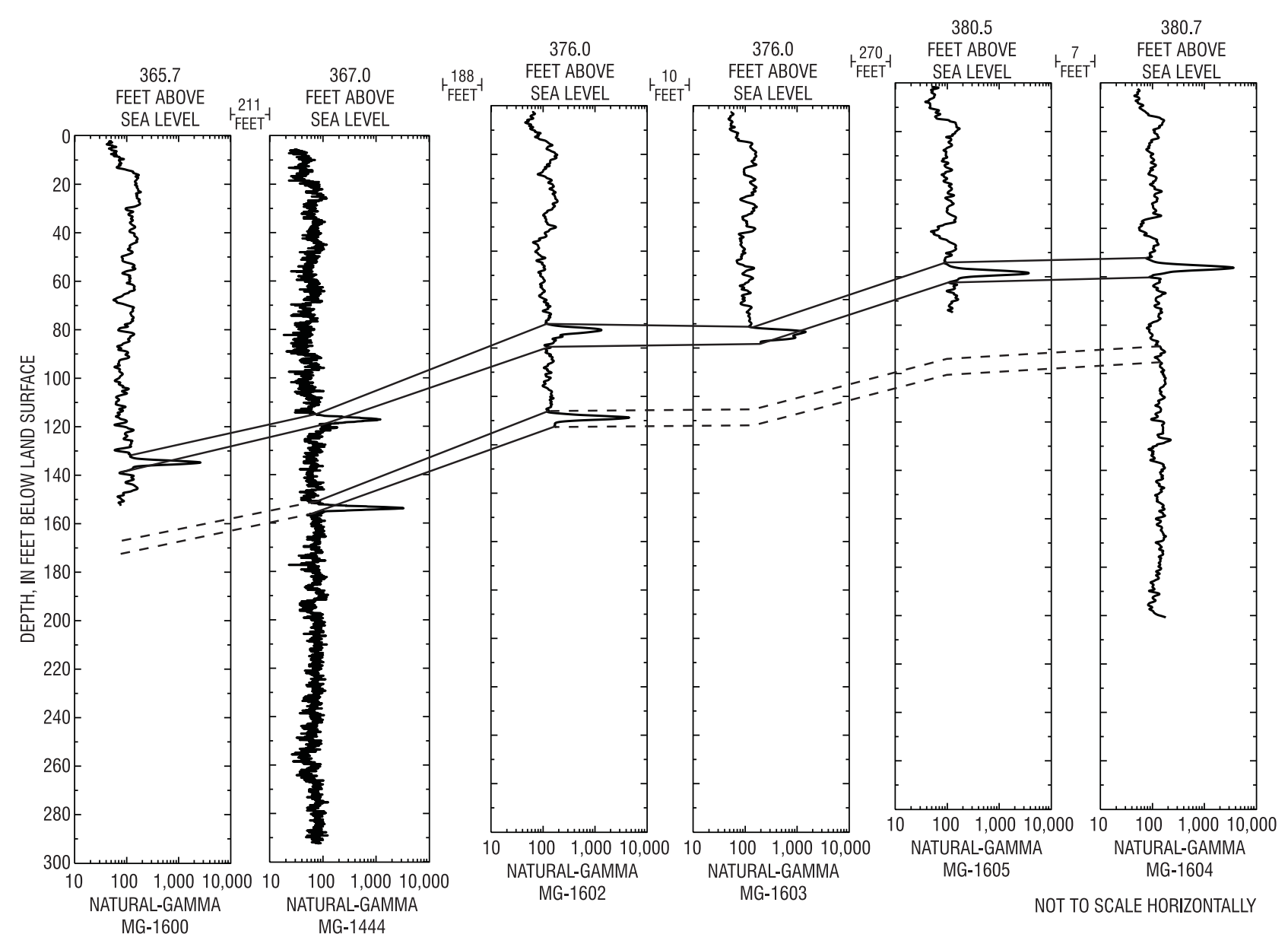

Figure 86. Correlation of natural-gamma logs MG-1600, MG-1444, MG-1602, MG-1603, MG-1605, and MG-1604, cross section $A-A^{\prime}$. (Dashes represent an inferred correlation.) 


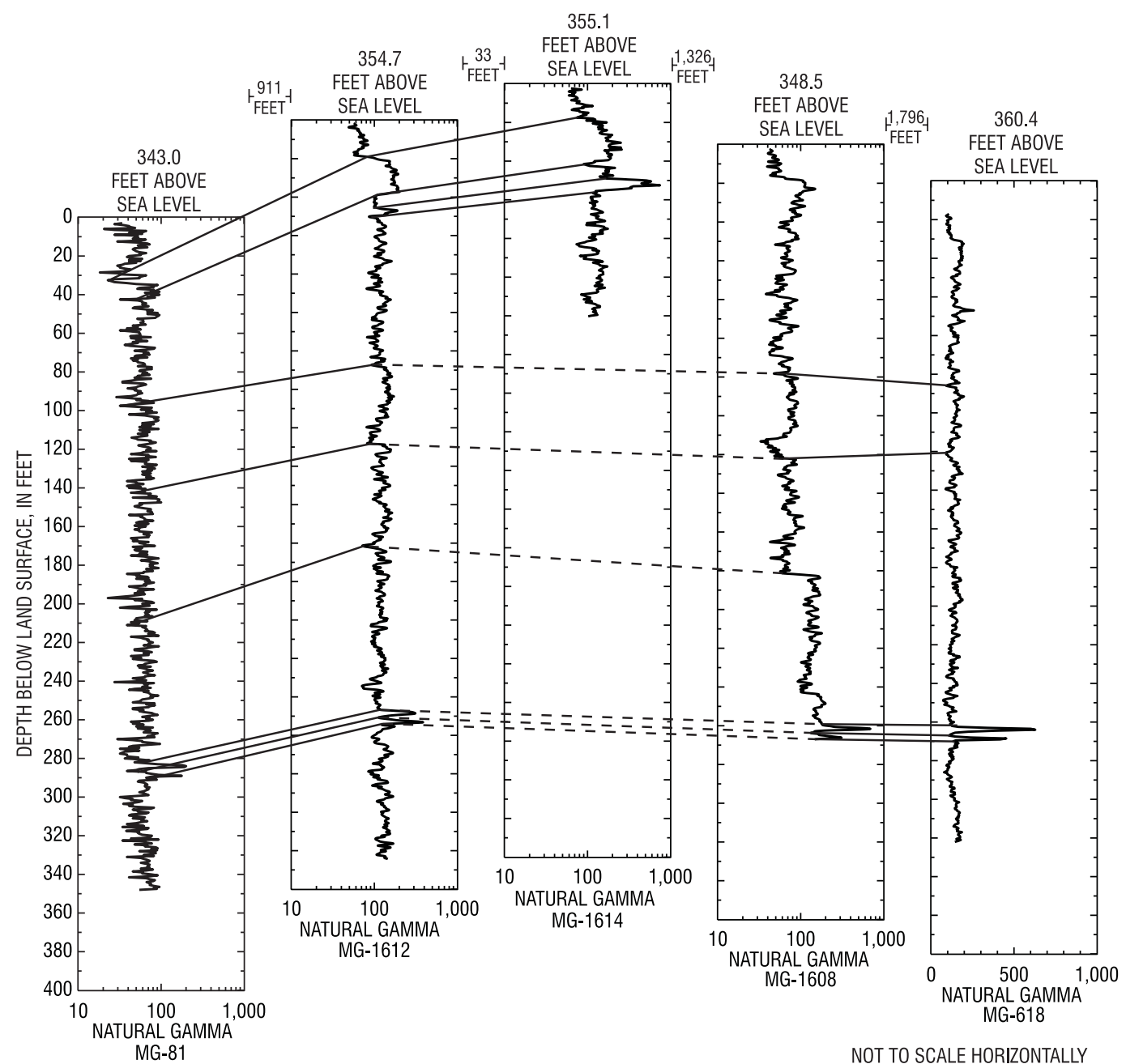

Figure 87. Correlation of natural-gamma logs MG-81, MG-1612, MG-1614, MG-1608, and MG-618, cross section B-B'. (Dashes represent an inferred correlation.) 
In the northwestern area of Lansdale, correlation of natural-gamma logs indicates that the strike of the beds is slightly to the east of northeast. The strike of elevated gamma readings in logs from wells shown in cross-section C- $\mathrm{C}^{\prime}$ is about N. $54^{\circ}$ E., with a dip of about $8^{\circ} \mathrm{NW}$. (fig. 1). Wells correlated in crosssection C-C' include MG-164, MG-163, MG-80, MG-1620, MG-1619, MG-67, MG-1615, and MG-1440 (fig. 88). The strike of elevated gamma readings in logs from wells shown in cross-section $\mathrm{D}^{-\mathrm{D}^{\prime}}$ is about N. $62^{\circ}$ E., with a dip of about $9^{\circ}$ NW. (fig. 1). Wells correlated in cross-section D-D' include MG-498, MG-624, and MG-704 (fig. 89).

Other correlations near the center of Lansdale and to the northeast of Lansdale indicate bedding orientations similar to those obtained for correlation of wells included in cross-sections A- $\mathrm{A}^{\prime}$ and $\mathrm{B}^{-\mathrm{B}^{\prime}}$. The strike of elevated gamma readings in logs from wells shown in cross-section E-E' is about N. $40^{\circ}$ E., with a dip of about $12^{\circ} \mathrm{NW}$. (fig. 1). Wells correlated in cross-section E-E' include MG-62, MG-64, and MG-924 (fig. 90). The distance between wells MG-62 and MG-924 is more than $2 \mathrm{mi}$, indicating that beds may be correlated along strike to distances greater than $10,000 \mathrm{ft}$. The strike of elevated gamma readings in logs from wells shown in cross-section F-F' is about N. $46^{\circ}$ E., with a dip of about $10^{\circ} \mathrm{NW}$. (fig. 1 ). Wells correlated in cross-section F-F' include MG-1616, MG-1613, MG-1624, and MG-1445 (fig. 91). 


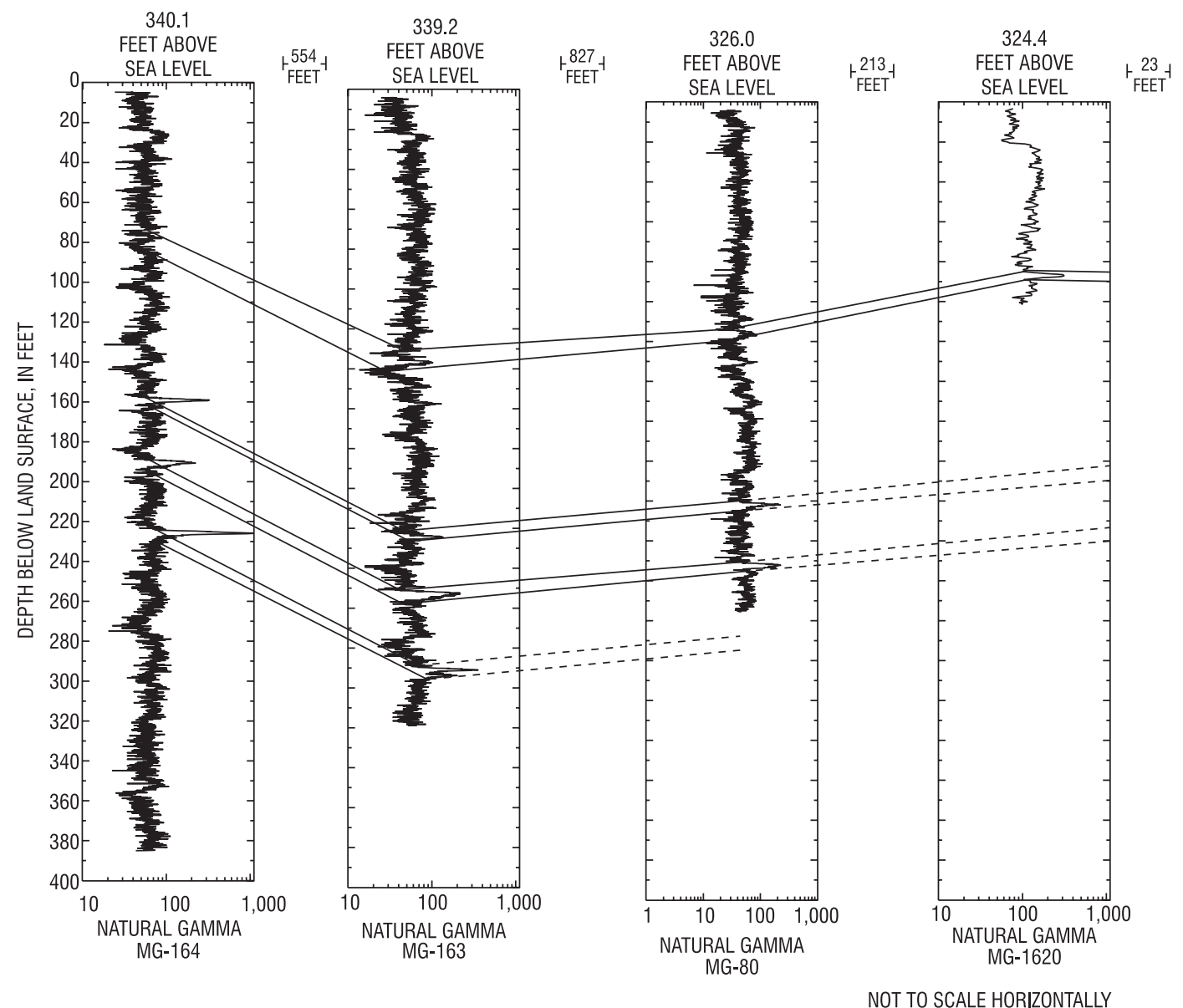

Figure 88. Correlation of natural-gamma logs MG-164, MG-163, MG-80, and MG-1620, cross section C-C'. (Dashes represent an inferred correlation.) 


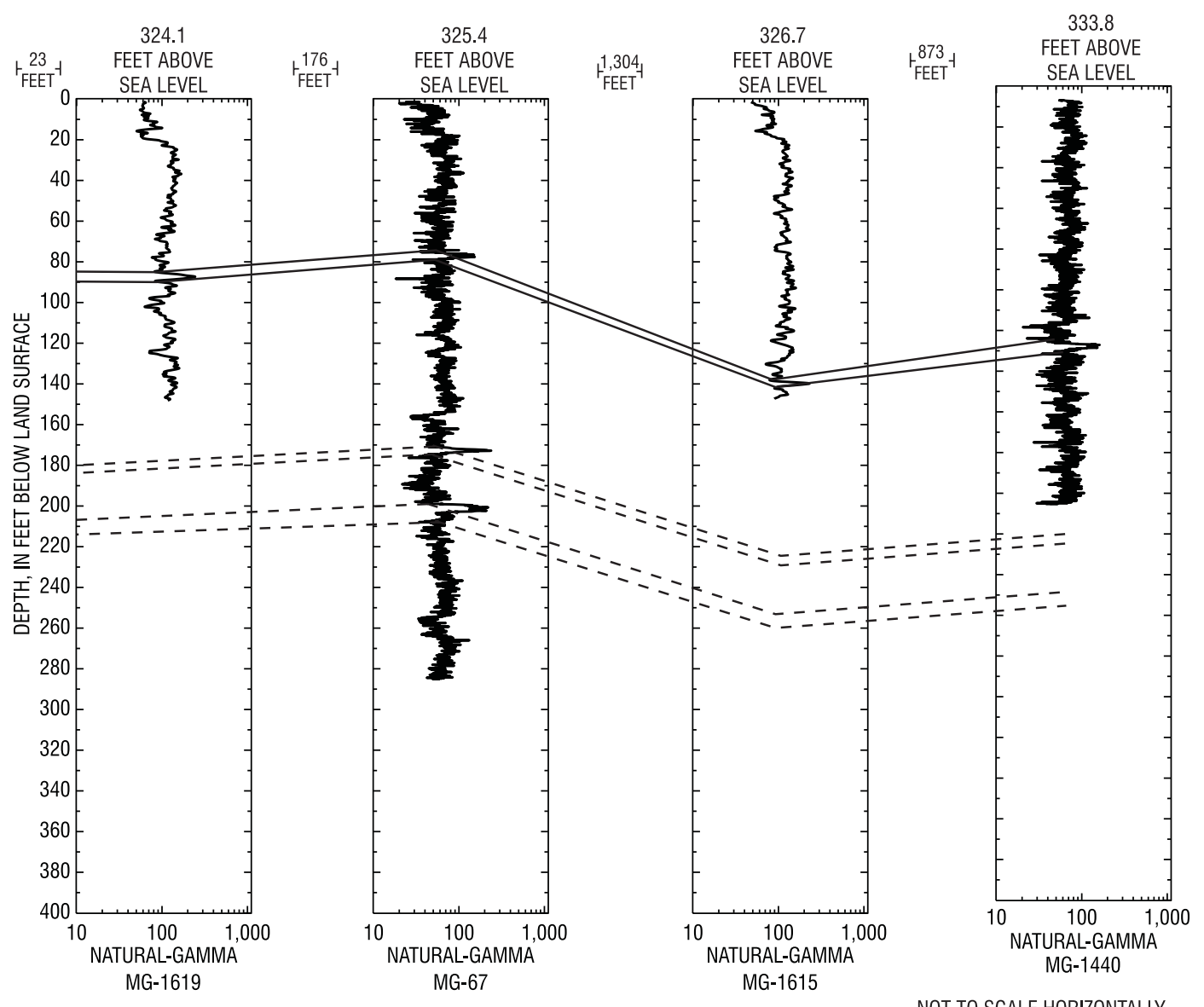

Figure 88. Correlation of natural-gamma logs MG-1619, MG-67, MG-1615, and MG-1440, cross section C-C' - Continued. (Dashes represent an inferred correlation.) 


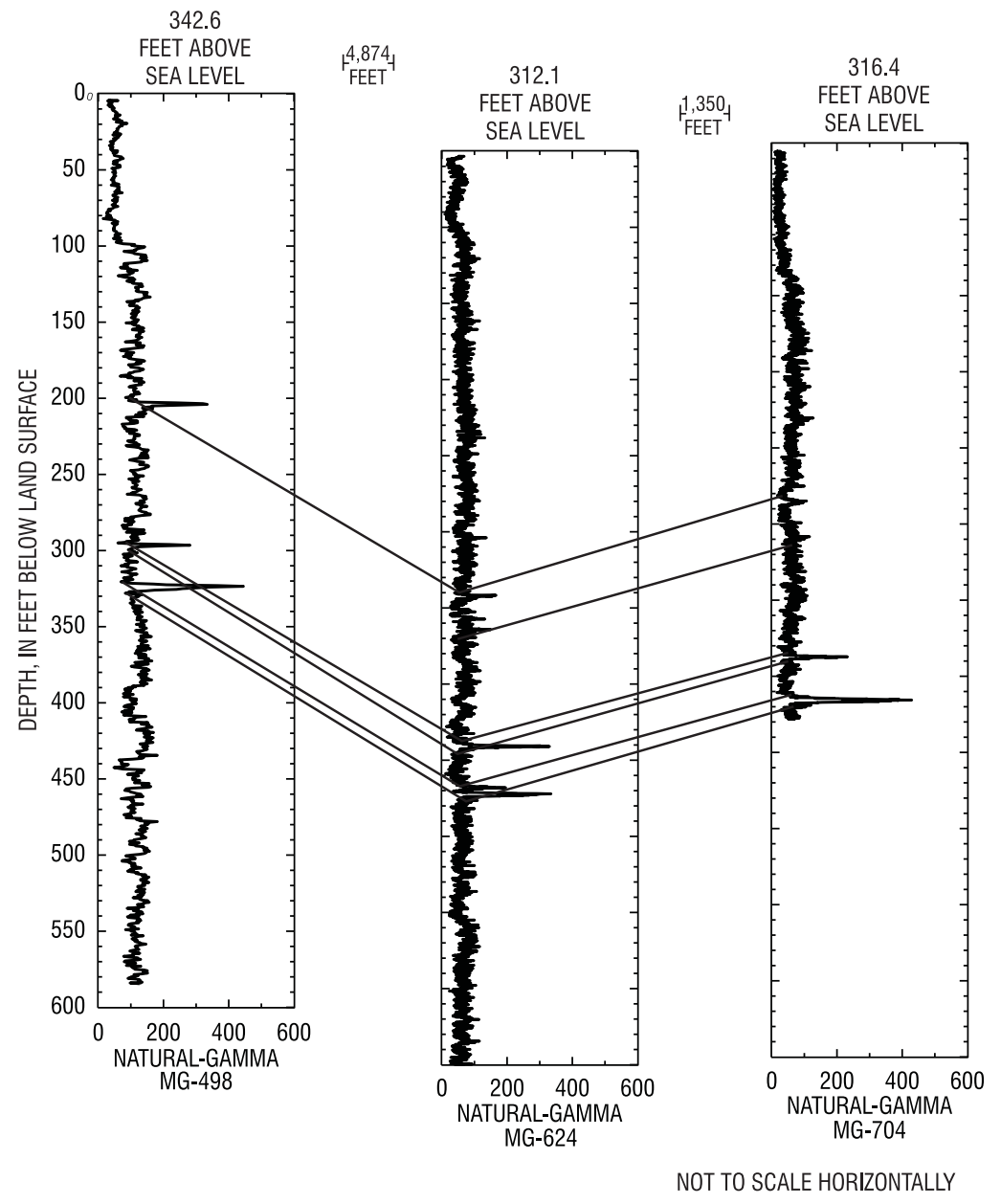

Figure 89. Correlation of natural-gamma logs MG-498, MG-624, and MG-704, cross section D-D'. 


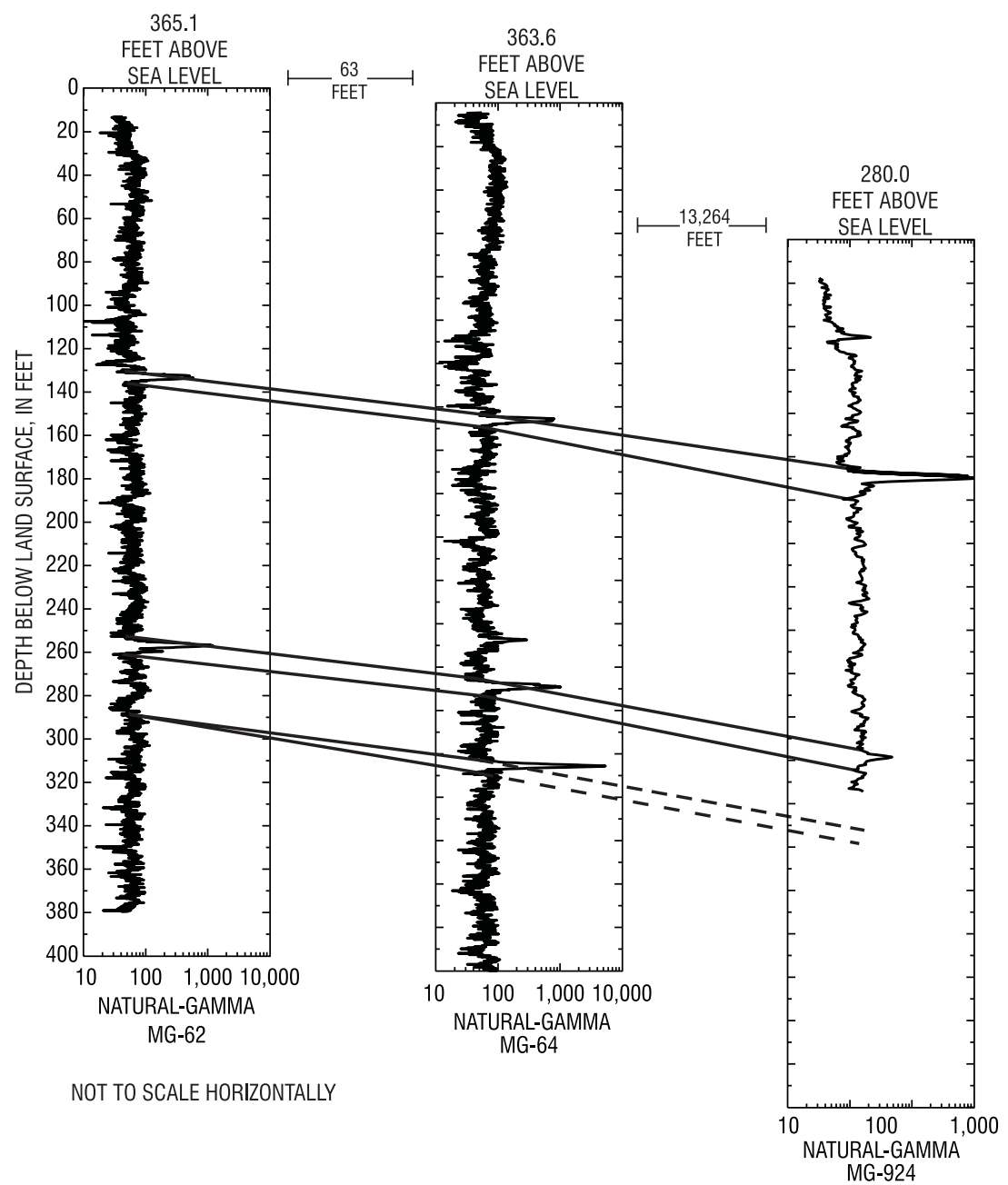

Figure 90. Correlation of natural-gamma logs MG-62, MG-64, and MG-924, cross section E-E'. (Dashes represent an inferred correlation.) 


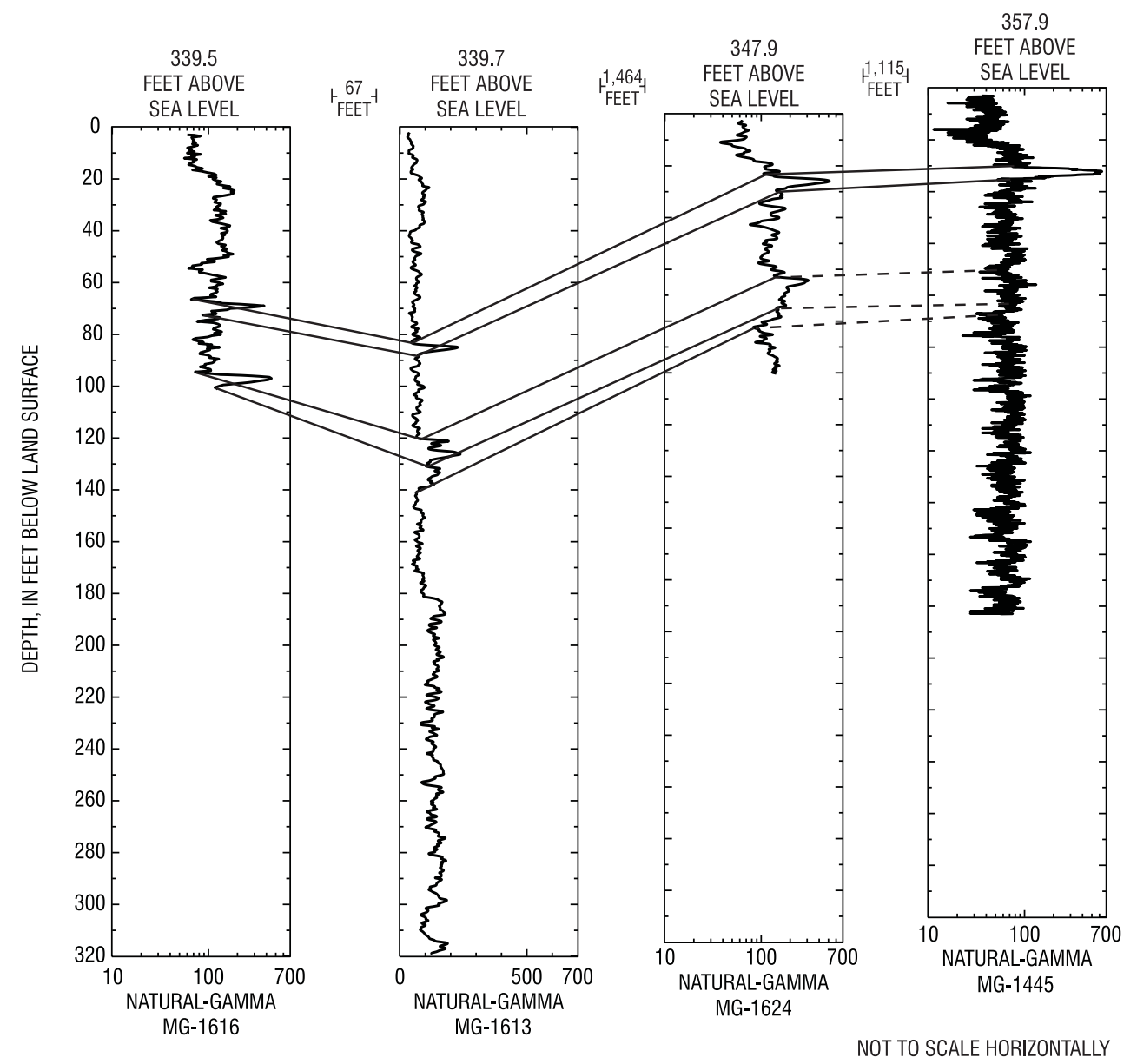

Figure 91. Correlation of natural-gamma logs MG-1616, MG-1613, MG-1624, and MG-1445, cross section F-F'. (Dashes represent an inferred correlation.) 


\section{CONCLUSIONS}

Generally, in the Lansdale area, boreholes constructed as open holes deeper than approximately $50 \mathrm{ft}$ penetrate multiple water-bearing zones in the Triassic-age shales and siltstones, and water levels measured in these boreholes represent composite heads. Water in the intermediate (approximately 50-200 ft) and deep (approximately $200 \mathrm{ft}$ or greater) part of the aquifer is under confined or semi-confined conditions.

Differences in hydraulic head with depth result in vertical borehole flow in open boreholes. Borehole flow, when present, was upward in 35 boreholes throughout the Lansdale area regardless of depth or location. Borehole flow was downward in 11 wells that may be affected by nearby pumping. Both upward and downward flow was measured in three boreholes. No flow was detected in eight wells. Any openconstruction borehole with multiple water-producing zones can potentially cross-contaminate other zones in the Lansdale area.

Correlation of USGS natural-gamma logs in the Lansdale area show that thin shale marker beds of the Brunswick Group and Lockatong Formation, generally strike $40-62^{\circ} \mathrm{NE}$. and dip about $8-12^{\circ} \mathrm{NW}$. in the central and northern section of Lansdale. Acoustic televiewer logs indicate that many water-bearing fractures are oriented similarly to bedding planes. Boreholes located along the regional strike of N. $48^{\circ}$ to $60^{\circ}$ E. typically can be correlated with natural-gamma logs. Boreholes that are located perpendicular to regional strike (dip direction) can usually be correlated, providing the boreholes are less than 3,000 ft apart, have similar elevation, and are at least $500 \mathrm{ft}$ deep. The frequency of shale units with higher natural-gamma readings increase toward the northwest.

\section{REFERENCES CITED}

Berg, T.M., Barnes, J.H., and Sevon, W.D., eds., 1989, Physiographic provinces of Pennsylvania, 2nd ed., Pennsylvania Topographic and Geologic Survey, 4th ser., map 13, scale 1:2,000,000.

Berg, T.M., and Dodge, C.M., eds., 1981, Atlas of preliminary geologic quadrangle maps of Pennsylvania: Pennsylvania Topographic and Geologic Survey, 4th ser., 636 p.

Black and Veatch Waste Science, Inc., 1994, Remedial investigation feasibility study report, December, 1994.

CH2MHill, 1991, North Penn Area 6 Phase II RI/FS and FS Work Plan, Contract No. 68-W8-0090, June 1991.

Conger, R.W., 1996, Borehole geophysical logging for water-resources investigation in Pennsylvania: U.S. Geological Survey Fact Sheet 218-95.

Keys, W.S., 1990, Borehole geophysics applied to ground-water investigations: U.S. Geological Survey Techniques of Water-Resources Investigations, book 2, chap. E2, 150 p.

Longwill, S.M., and Wood, C.R., 1965, Ground water resources of the Brunswick Formation in Montgomery and Berks County, Pennsylvania: Pennsylvania Topographic and Geologic Survey, 4th ser., Ground Water Report 22, 38 p.

Lyttle, P.T., and Epstein, J.B., 1987, Geologic map of the Newark $1^{\circ} \times 2^{\circ}$ Quad, New Jersey: U.S. Geological Survey Misc. Investigation Series, Sheet 2 of 2.

Rima, D.R., 1955, Ground water resources of the Lansdale area, Pennsylvania: Pennsylvania Topographic and Geologic Survey, 4th ser., Progress Report 146, 3 p.

Rima, D.R., Meisler, Harold, and Longwill, Stanley, 1962, Geology and hydrology of the Stockton Formation in southeastern Pennsylvania: Pennsylvania Topographic and Geologic Survey, 4th ser., Water Resources Report 14, 111 p.

Senior, L.A., Lesitsky, C.R., and Prieto, D.A., 1998, Altitude and configuration of the potentiometric surface in Lansdale and vicinity, Montgomery County, Pennsylvania, August 22-23, 1996: U.S. Geological Survey Open-File Report 98-253, scale 1:24,000.

Williams, J.H., and Conger, R.W., 1990, Preliminary delineation of contaminated water-bearing fractures intersected by open-hole bedrock wells: Groundwater Monitoring Review, Fall 1990.

U.S. Environmental Protection Agency, February 1994, National primary drinking water standards. 